\title{
WWMWAYNO NOWIONS
}

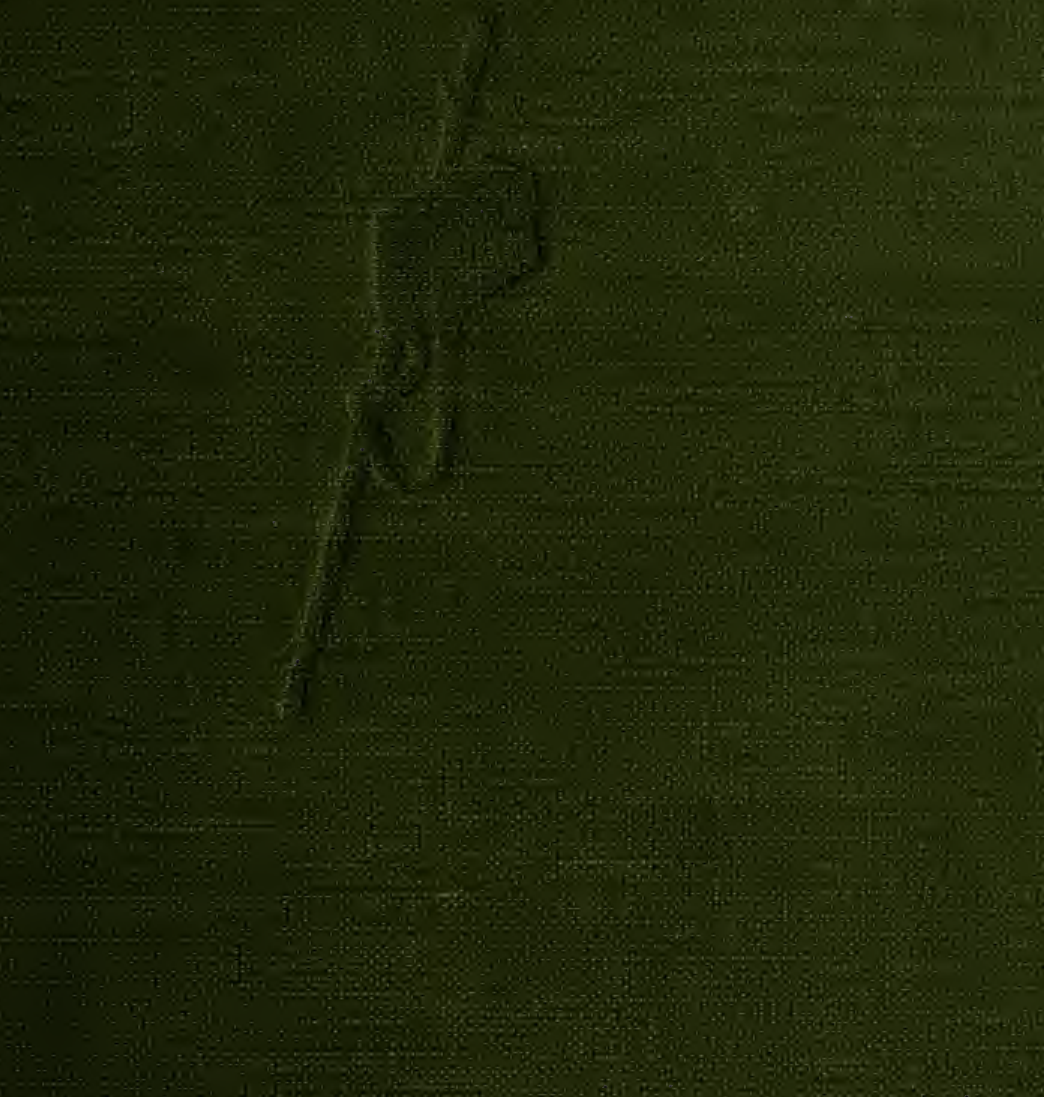

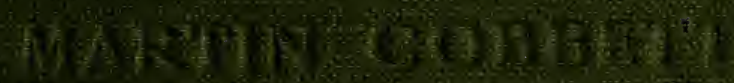

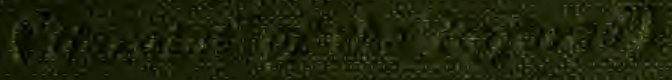




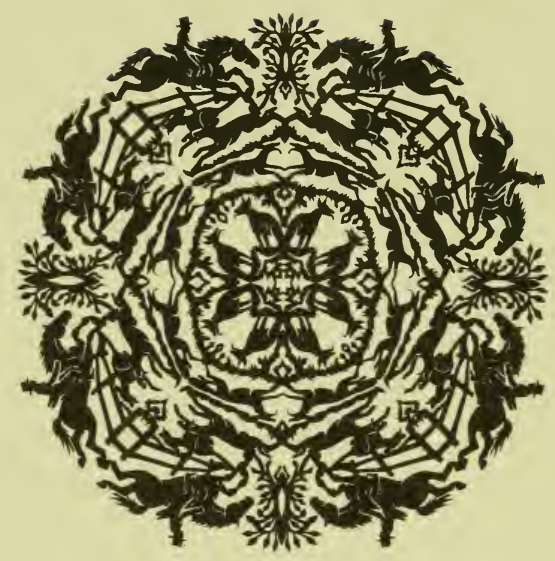

JOHN A.SEAVERNS 
$39090 \quad 014562314$

Wobster Family Library of Veterinary Medicine Cummings School of Veterinary Medicine at Tufis University 200 Westboro Road North Grafton, MA 01538 

WAYFARING NOTIONS 


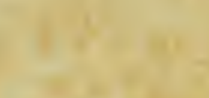

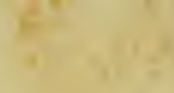

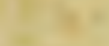

1

$\sqrt{2}+x^{2}$

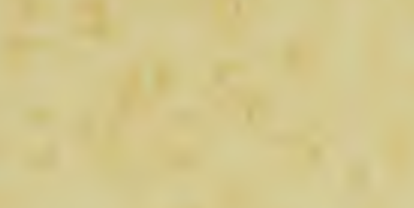

$4+2$ 



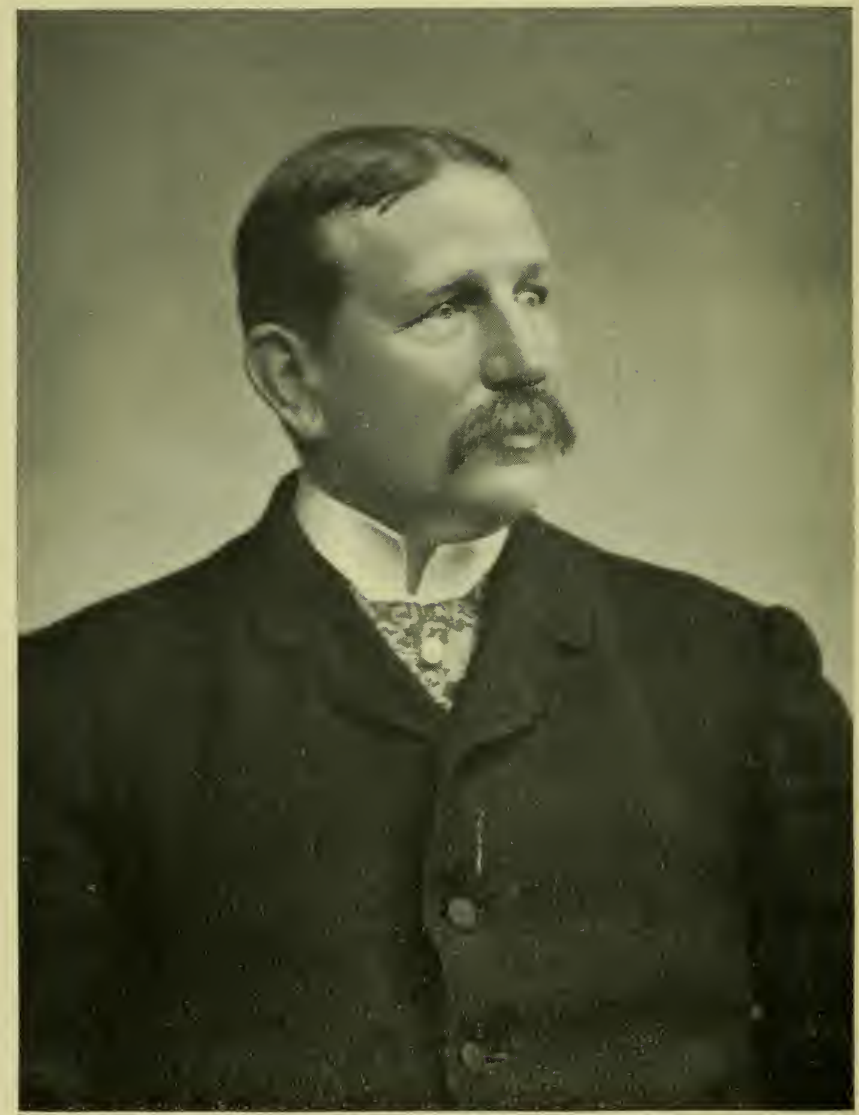

Photo by

Ellis \& Walery, London.

Murnu Cobhen. 


\section{Wayfaring Notions}

BY

\section{A R T I N COBBET T \\ ("Geraint" of the "Referee")}

AUTHOR OF "RACING LIFE AND RACING CHARACTERS," "BOTTLED HOLIDAYS," "THE MAN ON THE MARCH," ETC., ETC.

EDITED BY ALICE COBBETT

WITH A PORTRAIT AND MEMOIR OF THE AUTHOR

$$
\text { SANDS \& CO. }
$$

EDINBURGH : 2 I HANOVER STREET LONDON : 23 BEDFORD STREET, STRAND I 906 

TO

MY FATHER'S COMRADES

OF THE

"REFEREE"

I DEDICATE THIS BOOK 
₹<smiles>C1C[I-]1</smiles>

n

$x_{1}$

a

47

1

4 1

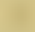

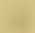

4

$+2$

1

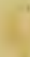

$\sqrt{12}$

$+2+2+2$

$x$

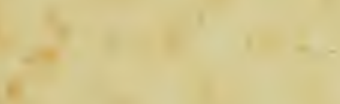

s

1

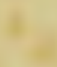

1

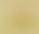

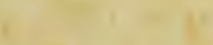

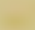

1

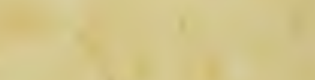

-

a

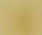

$\sqrt{2}+x^{2}$

(x-2 


\section{CONTENTS}

CHAP.

LIFE OF THE AUTHOR

PAGE

I. GLORIOUS GOODWOOD

II. IN THE SUSSEX DUKERIES

III. Patching and Selsey • •

IV. The Downs in Winter • • • • 37

V. Brighton to Newhaven • • • 52

VI. Plumpton and its Country • . . 65

VII. LEWES AND ITS COUNTRY • • . . 75

VIII. SUSSEX ROAD-LORE • • • • 100

iX. Rye and Eastbourne • . . . . ilo

X. Around Hampton Court . . . 125

XI. In AND About EPSOM • • •

XII. ARound Epsom AND Leatherhead • . 152

XIII. NEWMARKET . • • • • • 168

XIV. Newmarket Reminiscences • • • 182

XV. RAMbleS ABOUT NeWMARKET • . . 202

XVI. DONCASTER . • . • . • 222

XVII. DONCASTER Reminiscences . • . 234

XVIII. Chester and the Dee • . . . 248

XIX. In DeVONSHIRE • . . . • . 26I

XX. IN SOMERSET

XXI. IN AND ABOUT BATH

XXII. ASCOT AND NEWBURY $\quad$. $\quad . \quad 289$

XXIII. IN WILTSHIRE • . . . . 302

XXIV. WILTS AND HORSES . • • • 316 


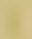

$y$ 


\section{LIFE OF THE AUTHOR}

IT has been thought that those who knew my dear father, Martin Cobbett, either personally or as his readers, would like this selection from his later work to be prefaced by a brief sketch of his life. No one can feel more keenly than myself how inadequate this memoir must be to give a real impression of my father's personality and character. What those were can best be indicated by the tenor of the many, many letters of regret and mourning evoked by the news of his death. From all classes, all callings, all parts of the world, with significant unanimity they struck the same two notes: "He was so kind," and, "I have lost such a friend."

Martin Richard Cobbett was born on 29th March i846. His forbears were yeomen of Surrey. The Farnborough district is the home of the Cobbetts, and thence came the famous William Cobbett, from whom the subject of this memoir was collaterally descended. Martin Cobbett was born and bred at Brighton, between the sea and the Downs-an environment which 
brought out and fostered that love of rowing, swimming, and rural roaming which was born in him and distinguished him through life. The first business he learnt was that of timber merchant; but he had ever a notable turn for sporting journalism, and in the seventies he took to writing for the Sportsman and the Sporting Life. Here are his own words on this subject, taken from the Referee of 9 th November 1902 :-

"Sporting reporting life is an estate for which I hold the greatest admiration, because, so far as its inner life is concerned, you can translate envy, malice, and all uncharitableness into jolly old pallishness; and no matter what part of the world a sporting Pressman comes from, he can rest assured of being put and kept straight. Imoi qui vous parle-have probably had more good turns done me than I have rendered. That last was not my fault, I do assure you. Speaking from within the prison-house walls of a craft which has the strange peculiarity that generally when you want a capable hand to join it you can't find him, and if you do not, you are besieged with applicants, I venture to say that no unhandsome turn will be given to a member of the profession, and if he is in difficulty he will be seen out of it-and no charge made nor price accepted.

"Plumming up my own sort, am I? Probably I am, and you can take it at that. I did not want to bring myself in, but as the Sportsman has occurred, I may cite that for purposes of 
illustration. Say I was 'doing' cricket, or football, or fighting, or rowing, or racing, and I was hors de combat, does anyone suppose that some good fellow of a competing paper or service wouldn't see me or my stuff through, or do the same for anyone else in the line of business? I give you my word they would, and be pleased to do so. Take self and the Sportsman. Barring its Dramatic Notes, I think there is no part of its répertoire that I have not done at one time or another to help a lame dog-excuse the simile as only partly appropriate-over the stile, and all the time was only doing what I feel quite certain would be done for me in difficulties.

“'Vigilant?' How many 'Vigilants' have I written-goodness only knows, many and many; just as I have 'Augurs' for the Sporting Life when the distinguished regular author was 'out.' My first connection with 'Vigilant' was funny. Brother Sportsman and Sportsmen, you will forgive me for going a long while back. Many years ago, a good old friend, Jack Mitchell, used to grind cut that article, and I was engaged otherwise than in sport or journalism, but all the same an occasional contributor to the Life and the $M a n$, and, I regret to add, a frequenter of race meetings. At Goodwood and Newmarket, Mitchell, rest his soul, would lure me on by offering me a seat in his reserved compartment. He always went through a set form: how tired he was, short of sleep, and how much better a fresh new hand could do a big day. At which I bit, and found myself with his notebook, his pencil, and his instructions to do a thousand words and leave the last race to him. After a time my wages were raised from getting nothing. 
It came to be an agreed bargain that I was to have something; so when we left Newmarket poor old Jack would produce two apples-one for me in præsenti, and t'other if I finished his copy and woke him up at Tottenham; guerdon which reduced me from the amateur to the professional ranks, because I was working for pay. In those days I used to buy the Sportsman as early as I could, and gloat over my 'Vigilant,' thinking what a clever chap I was.

"One of my funniest experiences was with a new man imported from a Midland paper, where he had been doing Board of Guardian meetings, inquests, and that sort of business, and was quite innocent of sport. He occurred, poor chap, full of faith in himself to report cricket, concerning which he did not know the leg side from the off. $\mathrm{He}$ had assured the firm he was quite au fait at the game, and they believed him. Bless my soul! we had not had more than two drinks and a little talk before I found that cricket was an unknown land to him. So, says I to him, says I, 'You sit down tight, and watch and listen to what I tell you; never mind about your copy, I will do all that. You've got to learnput your mind on the learning, let me write all your stuff.' And, after all, he was a cocktail, because he suspicioned I would give him away. So what do you think he did? Took the report I wrote for him, and varied it on his own. If he had mixed the introduction as to the weather, the wickets, the company, and all that, no harm would be done. But he carved the technical section about, and made a man stumped at mid-off run out by a brilliant catch and bowled at long-leg, so that my account and his should read differently- 
which they did. He was a man of little faith, and vexed me exceedingly, but no worse than another artist who performed quite the same feat with billiards, and changed the name of the strokes so as to make variety. He succeeded: but the variations were startlingly original, as, for instance, making 'long spot strokes off three cushions' and 'runs of winning hazards off the red into the middle pocket'!

"Dear, dear, how fondly I look back to those old days and enjoy reminiscences of the fine fun incidental to hurrying away telegrams of results, etc. ; grand sport, requiring you to be on your toes all the while, and up to all manner of dodges to beat time. Nobody shall ever be told how I beat all the rest of the agencies in getting off the result of a boat race, Hanlan v. Boyd, on the Tyne. There I was, in London, commissioned on a Saturday night by a rival agency to beat the Man in Newcastle, and had to do it. Beautiful it was for me. I got to Newcastle on the Sunday, the race was to be sculled on the Monday, and not a soul to help me. The Sportsman-fine organisers they always were-Messrs Ashley and Smith's services covered the whole ground-had enlisted all the Newcastle papers to aid them. Systems of rockets and pedestrian runners, cyclists, carrier-pigeons, guns, fast trotters, flags - everything but wireless telegraphy came to be laid on. Turn which way you would, the ground was jumped; wherever you looked for help-at least, where I looked-I was in the enemy's country. And I-poor me!-my instructions were to be first. How the devil can you hope to be first when you are single-hand, and all the powers are co-operating, defying competition? 
"There were my orders to be first. I had to get there somehow-and I did. I couldn't do it now-at least, I think not, though I can always run with a boat-race so long as I am allowed to shout. Once that day I was fairly beat, or looked like getting so. I hired a man with a wherry, or cobble, or whatever the boat's name is, and put him on a fiver to come to the umpire's steamer as soon as she got to Scotswood Bridge and take me off, and no one else. He was there all right. I did a wild jump from the paddle-boat and landed in his craft somehow. What did he do-pull like blazes to the shore to earn his fiver (it was worth a pound a second to get a start)? Not a bit of it. He backed to the side of the steamer and took all my rivals off at a shilling a head. Beautiful, was it not? Truly beautiful. He collected eight shillings, but never a stiver of the five pounds has he got from me to this day, for I was first ashore and running for dear life to the telegraph office, and would not have paid him had I waited.

"Very many old rowing men recollect Billy Winship, the Tyneside boat-builder, long with Johnny Clasper at Putney. Billy did me a fine turn that day, and I have heard him tell the story about it many a time and oft. I ran that time like as if the Devil was after me. Please note that I never could run fast with any comfort or precision, not being built for it, but needs must when the Devil drives. I was in the same position as a butcher's horse-I had to go somehow. Of I went to the best of my ability from Scotswood Bridge, with one of the opposition crowd, a Sheffield pro., left a hundred yards at the landing-stage-a nice start for me. And 
I ran myself right out, so that I came a most mortal involuntary, with no use to 'call for a cab,' as the steeplechase riders put it. Then occurred with the hour, the man-and the man was Billy Winship, whom I will quote for the finish of the story. Says Billy: 'There was Mr Notions a-running' (you should hear this in the Newcastle lingo!) ; ' he was a-running, a-running, a-running, at last he falls down, and he says, 'I am' (very, Novocastrian language) 'if I can run anymore.' Instead of which good old Billy collared the copy out of my hand, ran himself to the Scotswood telegraph office, bunged in the message, and the wires broke down before the next despatch arrived.

"Once, in Mr Billy Innes's great sculling tournament, I got knocked overboard from the Press boat, and swam ashore at Barnes, as did the Sportsman's young man, who was supposed to go down one side and up the other. Nothing but my old good friend Tom Tagg's stern resolution and presence of mind saved a whole launch-load from being turned into the water out of his launch that day and probably drowned. When you were in the water as I was you were not too happy because of efforts to administer first aid. An old gentleman hurled an iron pail at my head to keep me up, and two others launched a penny-steamer's quant or exaggerated boat-hook, which would have killed me fatally dead, and sunk itself, by reason of its weighty iron shoe, as soon as it got to the water. Thanks to not being assisted, I got ashore, and forthwith dispatched my account by wire from the Barnes post-office, whose mistress ordered me out of the place because I made it so wet. My confrère 
hadn't thought about Barnes for telegraphing, but made for Mortlake. (Later, twenty-four gentleman turned up at a Putney Rowing Club of which I hold the honour of membership, and wanted rewarding for saving my life. If I recollect right, Mr Pat Labat scored twelve quarts of beer to my debit, and finding the stairs full of applicants then, kicked the rest down.)

"Thanks to the Sportsman, I went Down Under with the Hon. Ivo Bligh, and there was made a member of the cricket expedition, and had the best time I ever found in my life. As a matter of fact, that commission as Special Correspondent represented one long holiday, seeing men and cities, and writing about them. With Mr Ivo Bligh I was, as attached to his team, a persona grata in all the Colonies of Australia, and I saw more of Australia in five months than most old Austral-Colonials do in a lifetime. Everyone was kind to me out there. Thank goodness, I have found many opportunities to wipe the slate clean by returning good offices, but at that I am much in debt. I, as I say, had the best time of my life, thanks to the Sportsman, gathered experience which has served me for long, and made friendships among Colonials which have borne good fruit."

The series of special articles on that Australian cricket tour may perhaps be taken to have established Martin Cobbett's position as a sporting journalist. But his knowledge of the racing world was so extensive that he came to write more on the Turf than on any other sport. 
He was the first "Man in the Ring" of the Sporting Life, and the pioneer of returning starting prices at race meetings. For many years he wrote for the Globe; he was the People's first sporting editor, under the name of "William of Cloudeslee"; for a long time he did the sporting article of the Penny Illustrated; he succeeded the late Mr Innes as "Pegasus" on the News of the World. A few months before the end he joined the newly-started Tribune as sporting editor. His connection with the Referee began in March I886, when that paper's honoured founder, Mr Henry Sampson, started on a tour round the world. From I9th August I877 (when the first number of the Referee appeared), up to the date of his departure for Australia, every line of "Pendragon's" "Sporting Notions" article had been written by $\mathrm{Mr}$ Sampson himself; and the article had obtained a deservedly high position in the world of sport. It was therefore a matter of considerable difficulty to find a sufficiently "all-round" sporting authority to temporarily fill "Pendragon's" place. It was originally arranged between Mr Sampson and Mr Richard Butler (who was entrusted with sole charge of the paper during his chief's absence) that the article should in future be a composite one, each contributor being a specialist in his own branch of sport, 
instead of being as hitherto the work of one man. This plan was tried for two or three weeks; but the salad didn't mix well, and the result was that $\mathrm{Mr}$ Butler placed the entire article in the hands of Martin Cobbett, and in Martin Cobbett's hands it remained until the week before his death. He became known as "Mr Notions" all over the world, the name clinging even after all the contributors had taken signatures in the style of Mr Sampson's ("Pendragon"), his own being "Geraint." In recent years he furnished the "Boris" article as well. It may be said that Martin Cobbett valued above all his other connections his position on the Referee. He never undertook fresh work that he thought might interfere with its claims, and perhaps it received his finest writing, unconsciously, as what we care for most inspires us best.

For the calling of all-round sporting journalism Martin Cobbett had remarkable, perhaps unique, qualifications. On this point I may quote the appreciation written by one of his comrades in the Referee of 29th April I 906.

"It chanced that when I first met him a big sculling match was occupying general attention, and his conversation showed him to be such a master of the subject that I put him down as an expert on rowing. I came across him shortly afterwards at Lord's, and then it soon occurred 
to me that if he had a strong point it must be cricket. A week later I read an extraordinarily graphic account of a race-not the skimpy summary to which one is accustomed, but a detailed picture of the struggle from first to last. You were made to see what each horse and jockey were doing from the moment the flag fell -this was in the days of the flag-till the winner had been weighed in. 'I wonder who wrote that ?' I asked a friend. 'Oh, that was Martin Cobbett,' came the reply, and ever since I have looked anxiously for this pen-and-ink realisations of famous events."

His great endurance and resolute industry ("The Cobbetts," he remarked, "are stayers") also formed invaluable qualifications for one of the most continuously arduous callings on the face of the earth. In his work he drew on his staying powers to almost any extent, without grudge or stint. At the same time he took the extra trouble-for a trouble and nuisance it very often is-to do everything possible in his scanty leisure to keep healthy and fit. Regarded as mere mechanical writing, leaving out his obligation to watch, remember, and form his own opinion of all he discoursed on, the amount of labour he undertook and carried through, always against time, was excessively heavy. Those who read his writings of the country, or who heard him talk about it-the half of what he knew never 
appeared in print-found it not easy to realise that he ever did anything but ramble and explore. Yet here is an ordinary specimen of his working day: Up at five or six, write till nine or ten; "go for a run"; cold sponge and breakfast; walk three to eight miles to a racecourse, hard at work there all the racing time; very likely walk back, change and dinner, write till ten or eleven at night; and repeat the whole as a matter of course next day. Many were the articles and also short sporting stories done incidentally to all his regular undertakings, as were his books "Bottled Holidays for Home Consumption" and " Racing Life and Racing Characters," which last filled a very long-standing gap; it described the ways and inhabitants of the racing world for the benefit and amusement of outsiders as well as of the initiated. In conjunction with his brother, Mr John Cobbett, he contributed a handbook on "Swimming" to the All-England series. His first book, "The Man on the March," was the outcome of a series of articles written while he was accompanying the American pedestrian, F. P. Weston, on the latter's memorable tramp at high pressure through England. In harness to the last, always cheery, and never complaining, he had done at sixty as much labour as most hard-working men at eighty - so remarked $\mathrm{Dr}$ Hearnden of Leatherhead, his physician and old 
friend. Literally, he died of work ; but it was through a piece of his own inveterate kindness and helpfulness that the finishing stroke was incurred. Heated with walking, on a bitter afternoon in a bleak district, he halted to help an old country couple whose little nag had fallen on a deserted road, and the consequent chill was the direct cause of his death.

Among his friends he was always called "Martin," or, perhaps, "Martin Cobbett,"-never his surname alone. His friends were not few; for, extra to his own brotherhood, the right good comrades of the Press, his acquaintance was immense. He knew and was liked by the whole great 'gamut of racegoers. Railway men hailed him as a looked-for face all over England. So did the rowing and boxing spheres: so did innumerable hotels and inns where he put up "on circuit," or called in during his walks; so did three-quarters of the inhabitants, dogs included, of every place where he lived. As for "the folk in fur and feather," he knew and loved them all, and was their general favourite. Our own dogs invariably adored him, and he had canine acquaintances all over England who thought it the greatest treat in the world to go for a walk with him. There was a couple of handsome poodles - they did not see him half a dozen times a year -who used to scream with joy whenever he was 
heard approaching their front door. A stable of his own he never had, greatly as he would have enjoyed it with his extensive knowledge and appreciation of good horses. As it was, he used to take delight in visiting training quarters and "paying calls," as he put it, on the grand creatures in their quarters.

His knowledge of English country, on and off the road, I take to be unrivalled-certainly unique among men so cribbed and confined by the exigencies of their work as he was. Delight in "seeing the land" was born in him, and never flagged. Our lately developed cult of the country found him already its past master, practising it instinctively, habitually, for love. He was passionately fond of the South Downs, and stands alone as a word-painter and interpreter of that curiously neglected and fascinating chalk range. It is doubtful if any other man could be found with such appreciation and intimate knowledge of the Downs, though born and bred among them. How many would, for the pleasure of it, start from Plumpton at four o'clock on a December afternoon to make across the hills to Falmer? How many know "the high ridges behind Lavant where the yew-trees grow?" or would take a "nice little walk" from Lewes to Telscombe, and then on, say, to Newhaven-and this with never a halt to ask the way (though 
plenty to pass the time of day with the lone shepherds and labourers to whom a cheery word is a boon). He was marvellously waywise, and used to complain humorously, with considerable truth, that when he did ask for directions he was always sent wrong, and could make out his route far better on a lone hand, though he might never have set foot in that district before. His work obliged him to live "on circuit," and to reside within fairly short distance of the London termini and close to more than one racecourse. Wherever we lived, he always made the place and district a source of enjoyment, and struck out any amount of excursions and rambles where no one else might have thought of looking for them. The family expeditions that he personally conducted among the Surrey Hills were a "liberal education" in better things than chopped-up booklearning, and joys for ever to look back upon. His habits of carrying a stone in each hand when walking for exercise, and of never wearing an overcoat or taking an umbrella, came in for good-humoured chaff from his friends, but he had his reasons. The stones helped his peculiar swinging walk when they were grasped closely" on one occasion in walking a trial he nearly pulped the second-recording watch doing duty for the right-hand stone." Either overcoat or umbrella would have sadly hampered his action, 
in which the balance of the shoulders played a considerable part; and he said, truly, that both were nuisances to carry and extremely liable to get stolen or lost, especially at race meetings, and then there you were, exposed to any chill that might be going. So he made a study of suitable underclothing and never sported more than one coat at once. But he stuck up for the tall hat, which he always declared to be really the most convenient and hygienic headgear going, pointing out that it held plenty of air, and arranged for ventilation, whereas the pseudo-athletic cloth cap, which he never wore, was apt to become a sort of hot poultice, and was stuffy at best.

Owing to the exigencies of business, my father could scarcely ever visit a district out of short reach of the places where his work lay. Thus much fair country that he would have keenly appreciated-for instance, a great part of Devonshire-he could never see. Moreover, his "off" and "slack" times occurred simply and solely when frost or fog rendered racing and other sports impracticable. He never got a free week in pleasant weather. Yet I never remember his complaining of this, nor of the circumscription of his areas of exploration. He acted up to his own maxims: "If your time's short, make the most of it," and, "Take what you can get, and be pleased with it." He varied his rambles as 
best he could, and welcomed any opportunity for a walk or a scull which he could get-or rather make, for the vast majority of his open-air jaunts he did in overtime taken before or after a hard day's work.

With his wealth of open-air lore he naturally came to interlude among the strictly "Sporting Notions" country notes and descriptions of wayfaring by river, road, and footpath, such as only he could write, and these came to form a feature of the paper. They attained a spontaneous popularity widely beyond expectations, "no one more surprised than the striker," as he used to say. People who not only knew nothing of "sport" in the technical sense, but who disapproved of it, took in the Referee year after year, as their letters testified, in order to enjoy "Mr Notions" country writing. To all sorts and conditions of men and women it seemed to appeal equally. He was looked upon as Richard Jefferies' successor, and the literary descendant of White of Selborne and William Cobbett, while his originality was praised by all. The contents of this book are selected from his later open-air writings for the Referee. The easy, cheery vivid style that appealed to every one never betrays at what cost the writing was sometimes done. Severe illness might oblige my father to dictate "Sporting Notions" instead of writing it 
himself, but even with his life in danger there never was a gap. The last columns he had strength to evolve appeared on 8th April I906. "There won't be any Notions this week-the first time for twenty years," he said to me a few days later. I could only try to say cheerfully how the gap would be noticed.

Naturally, he had little or no time for reading except in hours taken from sleep, but he always enjoyed a sterling book, and his taste in literature was as instinctively good as it was catholic. Dickens he knew and appreciated from end to end. He once characterised that author most shrewdly as "a shorthand reporter of genius." He knew Shakespeare and Sheridan, Lindsay Gordon and William Cobbett, Marryat and Besant \& Rice. In Miss Jekyll's "Old West Surrey" he was much interested, and he thoroughly enjoyed the Irish horse-and-hound tales of the SomervilleRoss partnership and of Dorothea Conyers. The last new book he ever read and liked was Agnes and Egerton Castle's "Rose of the World." Indeed, though the most ungrumblesome and readiest to be pleased of men, he had a remarkably fine natural taste in all directions. His life was too busy for "culture," but it was a family joke that whether in antique furniture or new books, live horseflesh or defunct Southdown mutton, "Cobbetts always knows the best." 
He was superbly unselfish, and his idea of pleasure in spending was to give and to share. It was a delight to him to cater for home. He provided dainties for us, particularly local ones, such as simnel and Eccles cakes, parkins, or Melton Mowbray pork pies, on the most lavish scale, and it became a commonplace that the quality of the meat he took habitual pains to secure for home consumption entirely spoilt one for ordinary grades. Hospitable he was to a degree which scarcely appears in ordinary ideals, let alone ordinary practice. No one, if he could help it, ever came to see him without being entertained with the best he had to offer.

Of his charity and kindness to all and any needing help, I will only say that it was as painstakingly sensible and discriminate as it was generous and wide. To take one small instance, in his walks abroad he was always on the lookout to give a few coppers and a pleasant word - neither trifles to the recipient-to any honest tramp-the man looking for work who does not beg, or when pushed to it begs reluctantly; or, indeed, to any decent plodder who looked as if he "could do with a bit."

The loafer who pretends to want a job and invariably shirks it when given, he detested. Equally he disliked and despised the incredibly low dodges of landgrabbers, the mean rich-of 
whom there are many, when the meanness cannot be resented; the caddishly inconsiderate persons of any class who, being charged a usually very moderate fee proceed, not only to take money's worth, but to waste and spoil-who, when changing in a hotel bedroom, smother it with mud, or take out a trim dainty skiff, and do their best to wrench and grind her to pieces; the hooligans who leave a track of smashed bottles and general ruin; the bigots who, hardfisted enough themselves, look down on the kind and generous whose calling, however strictly honest, it does not please them to approve of. "Manners" in the best sense of the word were a point of honour with him, and he thoroughly approved of the Winchester motto. In this spirit of careful consideration for others he always, though so broad-minded himself, strongly deprecated hurting opponents' or anyone's prejudices and sentiments, particularly about sacred things, and went out of his way to avoid doing so. His opposition to racing on Good Friday, and indeed in all Holy Week, is well known. He was absolutely fearless in standing up for justice and humanity. It was well remarked in the fine appreciation of his character which appeared in Horse and Hound for 28th April I906, that "he would always fight for the under-dog, so long as the 
under-dog would fight too," or indeed. much longer, if he considered the under-dog was really overwhelmed by odds.

The article just referred to also remarked most truly, that his motto might have been that of his old swimming club, the famous Ilex, "Labor ipse voluptas." He was a good sportsman and a twenty-four-carat amateur in the loftiest sense of that much-abused word. His idea of it was the etymological one, pure and simple-one who does things for love of them. In his eyes, no one was a true sportsman who did not regard the incidental trouble and exertion of his pleasure as "part of the fun," from filling and carrying down your own boating hamper to going a long tramp simply for the walk's sake. The pot-hunter, the man or club who will not enter for an event unless pretty sure of bringing it off, the young fellows who lounge about without energy to do anything unless they can "show off" or "get a bit" in some way-such as these he despised. He loathed all cheapening and coarsening of sport into mere gladiatorial show, and expressed himself on this point with a definite and most. wholesome clearness. At the same time, no one was ever less snobbish in his views of professionalism. He stuck up with kindly disinterestedness for the honest worker, making or 
trying to make an honest living, whether he were waterman, "player," or "bookie." For bookmakers especially he never missed saying a good word. He declared and showed solid grounds that, taken as a whole, no business is conducted on such absolutely honourable lines, engagements of the greatest magnitude being faithfully fulfilled with no other obligation or pledge than a pencil dash or two-and that no more charitable folk were to be found anywhere. Indeed he claimed ungrudging beneficence as a virtue of racing people generally, and he knew what he was talking about. I remember that in one day he collected on Lewes Racecourse over a hundred pounds for the local free hospital, an institution in which not one per cent. of the donors could have possessed the slightest personal or local interest.

For a due appreciation of my father's powers as an all-round athlete, I must quote those who can speak with authority, "An Old Hand" says in the article already quoted: "He was possessed of great physical strength and very exceptional powers of endurance. Circumstances prevented him in early life from taking that position on the path and the river which he could easily have attained had he been able to spare more time, but for all that he proved himself a first-rate oarsman and swimmer, and did some remarkable perform- 
ances when well on in middle age." The Nerus of the World notes his "long, careless stride that won him a momentous series of matches in the Leatherhead road, and often puzzled emulous pedestrians, who with quickening footsteps got no nearer." He walked from London to Brighton over and over again. When living at Brighton, he used to row in a salt-water wager-boat between Brighton and Shoreham-which towns did not then coalesce-and in rough weather. His style of fresh-water sculling was the old workmanlike, healthy kind which, as he himself described it, finishes with shoulder blades flattened on a straight back. He always took an intense interest in the river; Henley Regatta, he used to say, was the greatest treat he allowed himself, and the place would not have seemed complete without "his familiar straw hat with the L.R.C. colours." The London and the Thames Rowing Clubs valued and mourned him alike. A few years ago, he formed one of a Press "Four" whose united ages compassed two hundred years, and who issued a challenge to take on any crew of equal age, amateur or professional, at their own distance, but the challenge was never accepted. His ceaseless energy and pleasure in walking became proverbial.

In the racing world, Martin Cobbett's position was unique. His profound knowledge, his 
resolute energy, his absolute "straightness" and impartiality, his fearlessness and geniality, made him a place which perhaps no other will ever occupy. "His lovable, almost unique personality," said the Tribune in its obituary notice, "made him the trusted friend of high and low," and this note of his lovable personality was sounded by all who knew him. "He never made an enemy, or lost a friend." In his home he was ever and wholly unselfish, devoted, and tender. He passed peacefully away on the 24th of April 1906, and was laid to rest in the churchyard of Stoke d'Abernon, Surrey, loved by every soul who knew him. How regretted cannot be told.

For permission to reproduce the following selections from "Sporting Notions," my best thanks are due to the proprietors of the Referee.

\section{ALICE COBBETT.}

November 1906. 


\title{
WAYFARING NOTIONS
}

\author{
CHAPTER I
}

GLORIOUS GOODWOOD

DEAR ME! They talk, they do talk of Longchamps' beauties. I am perhaps rather inclined to be of a Peebly disposition, and claim my ain countree for pleasure, but how can you put Paris and Goodwood together? Take your place on the Stand. In any direction, on all the points for boxing the compass, you shall see a prospect to knock the best Longchamps can do. You are offered all sorts. High bare wind-swept down? There you are with Trundle (or Troundel) Hill. Wooded sylvan country? Gaze just a little bit off to the left, where lies Mr James's beautiful park. Mixed hill and vale pictures do you require? Look out straight in front of you, there is the article made to order, with the lofty ridges backing Charlton and Lord Leconfield's long wood in the far distance, a range of plantations running thirteen miles, and a most easy place to lose yourself in. Perhaps you prefer coppiceclothed high lands. Just off the course, if you please, beyond the Stewards' Cup starting-post, you find your wants catered for. Or the varied belts, clumps, and thick woods of rolling park 
lands. There is the mixture, a little to the south and east, and the flat fat lands between the hill's feet and the sea in the distance, all stained patchy with the orange to light creamy straw of the corn crops. Maybe the sea is in your line. Plenty of the same (not forgetting the queer indents of Chichester and Pagham harbours) is in your line of sight to help yourself to, and the Isle of Wight chucked in free gratis and for nothing. All these good things, and plenty more, are at your service when you go racing at Goodwood. And yet no one appears to think it bad form to take the best a stranger, such as the Duke of Richmond, has in the way of scenery and freedom to range, and then march off without so much as a simple "thank you." What would His Grace think of a stranger's coming up and returning thanks for being allowed to use his lovely estate, the domain, and miles of the countryside? Mad, very likely, so unusual would the civility be; but somehow, instead of being so unusual an occurrence as to stamp one as quite eccentric and unconventional, the civility ought to go as a matter of course-at least so I think.

Lovely, lovely indeed, is the Goodwood country, beautiful enough to make a poor man glad that it does not belong to him, because it must be very hard to leave. Moreover, there it is, kept up for him, the casual or habitual visitor, to enjoy as freely as the proprietor who bears the expense of maintenance. Each year that I am at the meeting I make vows to come down to Charlton Forest and the Park when racing is not on and enjoy myself as I could roaming about. But, alas! there is a faulty part in the programme, and I shall, I fear, never get my holiday there; 
for, you see, racing is always on, if not in West Sussex, somewhere else, and business is business. So the best one can do is to make the most of what opportunities offer of themselves or can be manufactured by taking a little thought and engineer a little overtime a' mornings and in the early evenings. Somehow, people do not seem to care to go in for this sort of thing much. They want all brought right to them, put down on the doorstep, so to speak, or carried into the house and spread out for consumption. Take an example. Within a minute's walk of the racing establishment is Trundle or Troundel HillTroundel on the old maps-a great mound making a landmark on the high ridge of these downs, ringed at its crown by the ditch of an ancient encampment, and marked in the centre by the site of the beacon revived at rare intervals nowadays. To climb from the course level to its summit takes a very few minutes. Once in the camp you have, oh! such a view, such views, in every direction. How many go there during the four days? One per cent.? Not one-tenth per cent., if you leave out the natives who in dry weather picnic on its slopes. There is the grand show, one scarcely to be equalled in any country, at your service free gratis and for nothing.

If the roadway that crosses the range at the foot of Trundle Hill were a "pass," or the eminence itself a "pike" or a "peak," and there was a "fell" to it, we might find it quite celebrated as a centre for tourists, home made and of foreign manufacture. As it is, plain Trundle Hill suffers alike from simplicity of nomenclature and easiness of access. Views? You can from its summit take in enough views full of variety to 
last a moderate sightseer for a twelvemonth. You can hardly ask for a brand that is not producible in the scope of a look round commanding range from far out to sea on the south, right over to the Surrey ridges on the north; from East Sussex on the one hand to well into Hampshire and Dorset. Very hard to beat is this part of the South Downs by reason of its being so well wooded, as they may not be farther east, because of exposure to the south-westers. I am not sure that they can be beaten. You see, they have pretty much all that can be claimed for the best of the inland ranges-Dorset, Wiltshire, Berkshire in the south, or the Wolds of the north-and the look-out over the sea as well, a very pleasant one with the fine grain crops on the belt of land that stretches under the hills' southern face right away from Portsmouth to Brighton, where it ends by reason of the chalk hills coming down to the sea. Over this belt the dews are heavy, and drought is not felt as it is further inland, a circumstance which accounts for the going being good at training quarters within this zone when further inland it may be desperately hard. Better wheat land you will scarcely find in the south of England, nor, I should say, much better wheat crops on an average. (Farmers in the Chichester district used to race for the distinction of first getting into the market a loaf made from flour ground from the current season's harvest, and, if they landed by Goodwood Week, thought they had done pretty well.)

As for the harvests nature provides free gratis for nothing, there are lashings and lavers of them in the Duke's country, go high go low. Our small friends' winter store is served up with 
abundance. Wild berries of all sorts show in great profusion, making not the least pretty feature of the down country. In that I include with the uplands the spurs and deep shady hollows, the hangers, coppices, and sometimes far-extending woods, the borstals and steep, rutty roadways off the crests, and the network of lanes, ancient bridle-roads mostly, which begin on the neutral territory before the hilly part is properly done with and the weald can be said to have fairly established monopoly-the meeting-place of the chalk flowers and such as flourish on the clay. In Goodwood Week the down flowers are almost at their best.

In the hedges and about the lower growing trees is the English clematis galore, the old man's beard, or traveller's joy, a rather mixed one to me in that it speaks of the year's wane and time's rapid flight. Can you find a more beautiful classic design than the briony, also abundant? Just here, where chalk and claylands join, the little clear springs come creeping out of the great sponge reservoir and go their way with cool alacrity to be regretfully remembered-the "coolth"-by the wayfarer who has climbed to the breezy but very sunny hilltops, for the farther he goes, so much the more distance does he probably put between himself and the possibilities of a modest quencher till he return to the lower levels. There you are-in West Sussex, at least-within easy reach of any number of pretty hamlets, generally boasting a church a-piece-what a lot of money there must have been about at one time for church-building! - mostly with a bit of a green, if not enough land of that sort to rise to the dignity of a common; 
at least one biggish farmhouse good enough for the half-squire, half-farmer yeomanry who used to dwell in them, and a number of ancient, with a very few modern, cottages, the former much the prettier to look at, and the new-comers better to live in. Once a year some small proportion of visitors to Goodwood make more or less close acquaintance with certain of these hamlets and their approaches, and are all the better therefor, as should be anyone for experiencing only one fine day at Goodwood, not counting the racing in at all. Why, it is worth the money to have the sun bring out the delicious thymy smell of the down turf, which may call up memories to make one sentimental or extremely material in thought, according as the cue given through the olfactory sense leads to reminiscences of past days and departed friends, or to the recalling of such gross pleasure as may be afforded in the consumption of Southdown mutton, whose excellence is in part ascribed to the aromatic seasoning in its "native" herbage.

Occasionally, when I do find time to think, I grieve that familiarity, through long acquaintance with much that is enjoyable, has bred-no, not contempt, that is impossible, but a sort of indifference. Thank goodness I can still derive excellent pleasure from doing duty at a venue such as the Duke of Richmond's "best farm." But I always feel a bit sorry for myself in that the freshness has died out, and I rather expect all to be in its very best form before I can be satisfied, instead of being made to feel small in admiration at the glories of Goodwood Park and the parts thereabouts. Imagine the pleasure a novice who came out of, say, the Black Country 
would gain from his first experience of the Ducal Park, Ducal scenic accessories, and Ducal sport!

Probably anybody ought to be thankful for having to take as work what so many regard as a luxurious pleasure, and that is what riles me, because I so often feel that I ought to be enjoying myself very much indeed, and I am taking no more notice of estimable points in scenery and other interesting details than a shopkeeper in St Paul's Churchyard does of Christopher Wren's cathedral, or a Westminster 'bus-man of the Houses of Parliament. All that is rather a pity, because if one did not get tired and the business might be carried out free of wear and tear to pocket and person, the post of wandering correspondent which I have the honour to occupy would leave little to be desired. Very little, I mean, so long as its occupier happened to be suited by being a cross between the Wandering Jew and an almost automatic realisation of perpetual motion, and preferred not living anywhere in particular. I grow so used to perpetual changing as to scarcely notice doing anything of the sort, though if you do pull up now and then to think (it is not often there is time for such a luxury), the rushing about is rather extraordinary. Certainly it did strike me that way one Monday when I happened to be filling my pockets with thunderbolts - that is what we call them in this part of the country where I at present reside and indite. I say that the quick and frequent changing of venue did come home to me this Monday when I was on an old Sussex hill road washed clean by the temporary torrents of tropical storms which had been flooding the land, and was picking up here and there quite a 
lot of thunderbolts (iron pyrites, are they not?) revealed by the water's rush, which had scraped off the face of the chalk roadway.

You all forget, don't you, sometimes? I did with these precious curiosities. They are curiosities in several senses, and more particularly because no one can account for their presence in the chalk (so says legend), unless they do really come with the lightning, or did drop from aerolites. As I was going to say about forgetfulness: here had I been fossicking about-fossicking, please, not fossilising-and collecting specimens by the dozen which were stowed in my pockets. When the apparent supply was exhausted I moved up over the brow on to the Downs to refresh myself with wild raspberries which hereabouts grow by the thousand (of canes), and after treating myself to as many as I cared for, I experienced a most unusual sensation-that is, I could scarcely drag about. I was tired, oh! so tired all at once; so very tired that I wanted to sit down and calmly consider the situation, which began to appear rather serious, and for choice go to sleep. There I was, right on the crest of a long series of high downs and for all the prospect of being come across by anyone in two or three days, I might almost as well have been on a desert island. What was to become of me if I collapsed? What was I to do if this extreme lassitude, this inability to walk my weight was progressive? (You pull your weight, so why not walk your weight? If you understand the rowing expression, the other puts a case very handily.) Suppose that I grew tired, more tired, most tired, and became a fixture-and I did feel quite 
beaten-done up to such an extent that I was absolutely afraid to sit down for fear I wouldn't be able to get up again, in which case there would be no Goodwood for me.

This was a very nice situation, for a poor body all alone by himself and fixed in a dilemma, not strong enough to keep on the move and morally compelled not to stop. You wouldn't believe how foolish you can be-at least not till you try. My disease, which, as I have endeavoured to demonstrate, was very alarming in its symptoms, made me chuckle when I diagnosed it properly. All the strange sensations, the loss of power, weakness of the legs, and drawn feeling about the shoulders were due to a very simple cause. Old, very old, iron pyrites dropped from the clouds or somewhere else, was the matter with me. I don't want any scientific gent to tell me that a thunderbolt is not a thunderbolt, because by no other name would it be so interesting. What I am going to say is that I quite overlooked the fact that I was carting about two pocketfuls of the thunderbolts I picked up, and had little by little declared myself goodness only knows how much overweight. It was a good job I made this important discovery, for I was much perturbed in mind, and was wasting what ought to be to me a treat.

A great treat it is to be up on the Downs between Petersfield and the Arun in the sweet scent-laden air, with grand panorama views spread out before you, the scenty turf to walk on, and the beech coppices-woods, I should sayfor shade if you desire it-I do not, because I believe in absorbing all the sun to be found-no company save the birds and insects, and, perhaps, 
a shepherd, ditto dog and sheep, and liberty to range where you please just as freely as if you were lord of the soil and tenant as well. Do you like to be perched up ever so high and play at a game of geography, endeavouring to give a name to the hamlets and commons, hills and pools, churches and woods you see dotted about away out on the weald, and mentally follow up the roads streaking the real visible map plan? I do. I dearly love this diversion, even to the extent of taking interest in a cloud of dust, which tells you that sheep are on the move along the far-away road.

Does it give you pleasure to watch the sly squirrels peeping at you from the other side of tree holes, and the young rabbits settling down to play after you have been still a little while, just as if you were not there at all, or, being there, didn't count? Is it a delight to follow the course of the fleecy clouds, some of them scraping the hills and on occasions illustrating the manufacture of Scotch mist, or on a bright day mark their progress across the low lands as their sheet of shadow runs over the landscape? Can the birds' little ways charm you? Do you like to be "chatted" at by little 'uns of that nature and practice, or scolded by the jackdaws from the old chalk-pits, or made funny noises at by stray pheasants, or whirred at by partridges, some of them young 'uns already nearly as big as their fathers? I do, I assure you, derive much satisfaction from all these matters, and that was partly the reason why I was so charmed to find that I was only suffering from a heavy attack of thunderbolts, and was otherwise all right, so that I was not to scare myself out of coming again. 
That being so, I was no longer timid about sitting me down to rest, a relief which gave pause to dwell on the flying about to which I alluded just now. "What a game it all is," says I to myself, says I. "This is Monday. Here am I, up, up aloft-like all jolly sailor boys when stormy winds do blow, do blow--on the South Downs. On Sunday-which is, or was, yesterday-I was being half-poisoned on the Thames through the water companies sneaking too much of the element, and in so doing exposing the mud to the sun's influence (and does it not niff?)." I may also mention that while on the Thames I was run down by an energetic young lady sculler and a contemplative, reposeful gentleman, the latter with notions of steering which were somewhat strange. He steered with the ropes loose, the boat heading up the middle of the river, and, oh! the Ironmould of Fate, the Referee in both hands, so as to be read comfortably.

The countryside at Goodwood does not alter much. If, as is inevitable, one friend or acquaintance drops out, you may pretty safely reckon on the successors going on their predecessors' lines. The same biggish houses are let each year to the same kind of customers, and the same cottages very profitably and similarly tenanted. If not the same horses draw the racing folk up the north or southern face of the Downs, the gees are very much the same sort, and I dare swear that a great many of the traps are survivors of the original stock put to this trade after being condemned for all other. The same dirt is on many of the aged gippos as encrusted them in the days of their youth-an altogether economical arrangement this, because one set of dirt does 
for a lifetime instead of having to be constantly renewed, as is the case with the misguided victims of conventionality who occasionally wash. The same children, or later editions qualified to personate those now grown up, chant the same doggerel about mouldy coppers, call you Johnny, and shout "Hooray" with identical enthusiasm. The same farm hands continue to regard racing and all its works with bovine indifference, save on the Cup day, when, possibly with a little outside assistance, they may over-celebrate the event of the day in evening beers at the pub. The same sort of dust millers the driving passenger on parts of the road not watered by the South Coast Railway Company and the Duke of Richmond. A lucky dog like me meets with the same free-handed hospitality from his friends with the fine tables under his beechwood shelter. The harvest presents much about the same appearance. The same wild flowers deck the hedgerows and struggle for life in the turf. You have to go through the same routine as ever-at least, I do-to get a newspaper or a shave, that latter being obtained at the cost of a three miles' walk each way to the excellent barber and amateur nigger melodist Wright, late Clark - poor old Clark of Midhurst-or after a similar in distance excursion to Singleton, where you sit in a tent at the back of a pub, and find that a scrubby chin like adversitee makes you acquaint with strange company. A foot-padder, which is not the same as a footpad, finds the usual difficulty in dodging hospitality in faring through the hamlets. I regret to say that the same sports do not appear to be carried on in the villages of an evening-there used to be good fun with the foot-racing. 
The Immemorial hills are there, thank goodness little touched by ill-advised cultivation as they are farther east. The woods vary scarcely from year to year, except in seasonable changes. If you care to pick up local country lore, you may gather the same old stories about the trufflehunting dogs ; the frequent fox and the occasional badger; the trout which seem too big for the streams they adorn; the apocryphal big snakes; the wopses; the hornets (four kill a man and five settle a bullock); the poachers; the lying-out deer; the new men and the old; the very little men claiming this for their "native" who were, to begin with, thought nothing of, like a prophet in or out-which is it?-of his own country, and finished big in London; and the game fowl for whose fighting abilities no further use offers because Cocking-the sport, not the villagehas been quite done away with. The yarn about the bold smuggler, captain of the band, who, challenged by the Preventive man in the "'oods," downed 'un and left half a dozen kegs under the defeated coastguardsman's bed next day and did it all unbeknowst, is an annual so hardy as to rank as a perennial classic which never alters, save that the gentleman who ran the illicit goods gradually becomes more and more terribly noble. And the same jokes go with the same success each night at pipe-smoke time in the pubs. One ancient vested interest though, is being knocked out by the march of civilisation, A genius has started cycling for correct-card-distributing purposes. The poor, old-fashioned, hard-working bodies who used to run from Chichester for miles to serve their customers are being easily defeated by the innovators who slip over from the printing 
office to Midhurst in no time, and can beat the train.

Of course, when you come to the racecourse itself there are indeed alterations. The old stands and buildings have gone. Being gone, we might say nothing but good of the former installations or say nothing at all. That last would be scarcely fair and quite ungrateful, for if the buildings were not suitable for the custom that had grown, and grown out of all knowledge, as Sussex people say, and failed to give all that was wanted, they seemed to serve well enough before we began to get so particular, and everybody must have the best berth in the ship. Bear in mind, people raced differently when George Tattersall put up the stand we knew, and the idea that on a racecourse you should have as good a lunch as would serve for a lord's wedding breakfast, with attendance to match, and at about a third the price, had not even germinated. 


\section{CHAPTER II}

\section{IN THE SUSSEX DUKERIES}

I ASK nothing better, come spring, summer, autumn, and winter, than to visit the Sussex Dukeries. An opportunity came in the second week in January; so I accordingly off'd it to Goodwood with a willing mind, as the sailors used to say in round-robins. I will mention the great good luck I had as reward for starting with a falling barometer, a south wind, and a cloudy sky to take my chance on a tramp from Arundel to the Grand Stand-only one stand ranks here, and that is the Duke of Richmond's new one.

I expected bad weather, met nothing but the very, very best, and was thereby induced to make the most of a good thing by going the full course and a distance, a very considerable distance. A full course it is, too, for a poor old man on pappy footing to cover out and home from Arundel to Trundle Hill, ov'erlooking the Grand Stand. Still, every inch of it meant solid enjoyment. What a day was Thursday, bright, clear, with a keen wind to wake you up while you were out of shelter and almost too advanced spring on the lee, which was also the sunny side! Being a bit of a believer in chancing your luck on your own rather 
than ask your way anywhere, I did get vexed with myself for at first listening to local topographists bound to be wrong, as they were. Still, they could not make anyone put a foot wrong in such lovely weather and grand country. An eminent tradesman at Arundel sent me four miles roundabout. All extra blessings on his kindly head! I only wish he had directed me to wander forty miles instead of four if only time and the legs for the meander were available.

I made a short cut from Arundel to Slindon, going right through the Duke of Norfolk's parkdomesticated-downland de luxe to Whiteways Gate, which is on the road from London by Pulborough to Chichester and Portsmouth. Getting on for two miles and a half it is through this lovely holding of the Duke of Norfolk's. All the way the intelligent observer can discover objects of interest, views sylvan or romantic, restricted to a visible horizon formed by the wooded crests, with the thorn and maple, dotted hollows, or far reaching as, for example, the vast grand scape over Arunside to where Chanctonbury Ring dominates a climbing scale of high hills or the broad outlook northwards with Black Rabbit's disused old chalk-pit standing up bluff as a Derbyshire peak cliff in the foreground.

If the domain and the ducal estate generally was not so important, I would envy His Grace of Norfolk. But I am, I expect, better off than he as regards his property-richer except in thanks, which I tender now, as I always do in spirit after being privileged to make use, free, gratis, and for nothing, of great folk's property. Bless me, surely it is a thousand to one on the casual visitor against the proprietor - at least, so 
appeared to me as I doddled along thinking of Lord Carnarvon's great house near Bingham, up Nottingham way, with its window for each of the 365 days in the year. I hope that he does not find it so, but I can well imagine the lord of the place seeing cause for a fresh incidental worry, disappointment, or vexation out of every window, while the man who contributes "nix" to upkeep has no reckoning of such drawbacks in his constitution.

From Whiteways Lodge towards Slindon the high road runs through quite as park-like a country as you might name. Curiously enough, I came straight from the box, elder, and yew, and enclosed down park of Norbury, hard by Mickleham, where continually crop up groves that make you expect Claude Lorraine or Poussin to be about sketching, or at any rate successors in their specialities. For, say, a couple of miles this highway runs through a ribbon of this sort of country, carrying more yews and finer than I have seen elsewhere. Peeps of farms show you Caldecott rufous-toned brick, old-fashioned homesteads, peaceful havens, no more in the world as regards noise and racket than they were a hundred years ago. Smoke is a thing not to be dreamed of. Mist is mist, not fog, and the high woods ward off the tearing gales which a mile or two south cut up vegetation as though sliced with a knife. Pretty good to go on with, says I, and better still was Goodwood when I arrived, taking on the way some of the grandest Spanish chestnut trees in the land. Cowdray Park, at Midhurst, where, on the occasion of a fire a long while ago, the country-side braved danger to save Lord Egmont's furniture and pictures, and saved them 
for themselves, is not in it with these. Many choice bits and articles came my way on the road to the ridge, where, in air clear as an Australian sun can give, and with half a gale to blow all cobwebs out of your brain, you didn't want any Davos Platz, or places of that sort, to make you well and keep you so. Will my readers take all the complimentary things I have said from time to time of Goodwood in and about, draw a thick line under them so as to read them in italics, and make that do for this appreciation. What a course it is, with its old down turf!

I stayed about the tracks as long as I could, and then, not minding about directions, made off on a line of my own along the ridge, never going to right nor left, but straight away on a voyage of discovery over a delightful road where it was a road, one not ruined by steam-rollers, as is the highway from Arundel to Chichester. In eight miles I did not meet a soul barring two children and a donkey, one of the children riding in the bleak breeze without an inch of stocking on its poor little legs, and didn't want to. Thanks to going my own road I came out right at the Whiteways Lodge before-mentioned-I guess this was a Roman road to begin with-and so back to the Norfolk Hotel, the changing light putting new faces on the landscape with each new tone, the big red deer stalking about with alarming dignity, and the ancient maples looking sturdier and more obstinately unflinching as the fading daylight showed them bigger than they really were. Anyone who can do fine art criticism with " motives," "themes," " notes," and all, might make quite a pretty study of the English maple as it grows in the South, expressing in every 
branch, twig, leaf, and seed-key the Sussex man's motto on the Rye china pigs, "Wun't be druv."

Now suppose you want another walk-in August, say. What about Cocking and its peaceful churchyard, with the beautiful many-boled lime tree and the chalk stream, its boundary, running into the mill-pond? Does the persistent lady dabchick still insist on building among the reeds on that pond-when I was last there a much, too much, weed-grown dammed-up piece of water, whose overflow makes a most romantic cataract and falls? By the way, while talking of cataracts, I noted the other day reference to the late Captain Webb and his final swim. Reading the memoir one would be led to believe in the Falls and the Rapids and the Whirlpool being all of a piece. End from end they must be nearly two miles apart. Everyone who sees illustrations knows the Falls by sight. After the river has tumbled over it enters on a wide expanse, with a by no means startling flow, and remains thus so long as its walls are far separated. Below the suspension bridge the river's bed narrows and deepens till the weight of the stream from above causes a mighty rush in the restricted channel fearsome to look on, seeing that the current absolutely piles itself above bank level, terribly fascinating in its course, calling to you to come, yet simultaneously telling plainly your probable fate among the submerged rocks. These send up great jets like to a whale's spouting. Webb would have come out all right, given luck-great luck is wanted-to escape being driven on to these rocks. But his chance was a very outside one, and, as those who know the circumstances can tell, fully taken into consideration by the plucky 
sailor who had lived his life. You will not find anything terrifying in the Cocking waterfall, only a few feet deep, but charmingly pretty all the same; though the poor dear dabchick nesting a few yards away used to endure many tremors through the British boy and his stone-throwing, causing the good lady to dive and hold on to her nest's reed-stem supports under water till the bombardment ceased. With pleasure I would have looked her up-her daughter, granddaughter, or whatever matron carries on the succession now -as also the swallows who build on a beam not a foot above the sawyer's head in the wheelwright's yards.

Lower are little pools, icy cold, under the overhanging bushes - drinking-fountains for wood-pigeons, doves, and all manner of thirsty birds; and farther away a shelving rabbity hillside, beloved of kingfishers, whose name I left off mentioning years and years ago. 'Cos why? I reported to a local worthy my seeing a pair of the rufous-chested beauties. "Danged if I don't go and shoot 'un!" says he, straightway taking down from an unlocked rack a double-barrelled gun kept loaded and cocked in case one of the family happened to want to manslaughter another, I suppose. Had I fared to Cocking, on I must go to at least Cobden's house and memorial monolith half-way to Midhurst, and, being so far, wander to Midhurst's lovely common-a blaze of purple bloom-where I used to be pretty sure of finding white heather, genuine white heather, not ling, finishing up the trip in that direction by crossing the bridge at Midhurst and twisting round under a long, hanging wood for a swim in the Rother. Would you care to do that last, my reader, 
should you chance to fare to the quaint old town? Well, that being your inclination, you might as well inquire of a native for the bathing-place's "marks." What sort of cheerful direction will you receive? Very plain and encouraging, You go through the wood till you see the post put up "where the butler was drowned."

Branch off to Lavington, home of several Wilberforces, and a cure once held by Manning. As a matter of fact, my first pilgrimage to the beautiful little hamlet, near where is Mr Buchanan's new stud, was on account of Cardinal Manning's association with the locality one should on no account miss exploiting, for it is very lovely. I have a lively recollection of a longish journey from Shillinglee Park, and a remarkably short bill for a very fine meal of rabbit-pie baked hot-pot fashion, cold fat pork, and lashings of beer. What the precise sum was I forget, but I do recollect the lot's coming to under sixpence and there being an odd farthing in it, also the landlord's refusal to take more. I know I calculated that if bed was assessed on the same moderate platform as board I could live for about $£$ I 5 a year and spare a quarter of that for washing.

Or pull up one of the chalk lanes, where are hangers in place of East Sussex bostals, on roads studded with pyrites, commonly called thunderbolts, plain to see after rain has washed the chalk surface clean, just as you may pick out specks of gold in some Australian towns. Wild, desolate country some would call the land you strike on the highlands. It is homely to me, though disfigured through digging out flints, thus making perilous walking for the unwary. Here you are with a view hard to beat wherever you strike on 
a range of downs bordering one of Lord Leconfield's woods, miles and miles and miles long. Had I been sound up to this I must go to make myself qualmy inside with wild raspberries out in the open, also strawberries on the edge of the rides engineered with eight or more dials from any number of centres. Lord help the inexperienced stranger lost in these woods. He might take a week to get out and not see a soul all the while.

Then there are the chains of villages from Lavant by West Dean, Singleton, Charleton, East Dean, worth exploring. I have been, and still would go through these if only to fossick about the stabling and pick up cues from the plates bearing names of winners housed at the various yards, calling to mind generations of bygone equine celebrities-their owners, trainers, riders, and "schools," mostly all passed away into forgotten memories, only revived by Turf students who, speaking by the book or record, make very skeleton stories of true happenings.

And then the rivers. You've been to school, how many rivers are there in Sussex? Quick now! I know three through experience as an angler and a navigator-the Ouse, which might be a deal better than it is; the Adur, about whose estuary arms I could amuse myself for many a day; and the, in many places, dangerous Arun, good for the angler from mouth to sourceperhaps I ought to begin at the beginning and turn the ends round-and affording variety of scenery not to be equalled by many far more pretentious streams. One of the ambitions of my life was in connection with the Arun, and will never be gratified. I did want very much 
indeed to voyage from Putney to Littlehampton viâ Thames, Wey, Wey and Arun Canal, and Arun, but I missed the chance I had, and next time I might have gone in for the journey cattle were feeding on parts of the canal's bed, and there was an end of that idea. Then there is the Rother-I have been in that more than on it - and the Mole, which, as a Sussex river does not fairly count, being only a little chap till he begins to get clear of the county and play pranks with sinks and swallows, justifying his name by working in the earth like the gentleman in the fur waistcoat. Some day I mean to make up for the Wey-Arun disappointment by tracking the Mole to its very source in Tilgate Forest, like $\mathrm{Mr}$ Pickwick and the Hampstead ponds.

These are all the Sussex rivers I know as a fisher and boater. I ought to explain that my Rother is the one so pretty by Petersfield and Midhurst way, not that near Rye, which finds its way along to the sea from Rotherfield. This Rother and I are acquaintances only. It is not an associate, as the others have been, old friends for whom I am not afraid to stick up. Shoreham Harbour, the Adur's outlet, may not be all fancy paints the Rhine, but it can serve. Bits on the Arun about Black Rabbit might be backed against the pick of Clieveden without being beaten. Not many more beautiful, quiet, fishy, wooded corners than the Western Rother owns are to be quoted from your show rivers; and as for the Sussex Ouse-well, if it were not for the slime and the sewage and the absence of landingplaces, and the defunct dogs and other animalssome in mysterious packages of quite Bosphorean tone-doomed to find no rest after death, but 
float for years and years and years up with the flood and down with the ebb, and other little matters, why the Ouse would be something to be proud of in a small way. This Ouse, whose mud is own brother to the Yorkshire namesake's, a proved salmon river, while the former has only traditionary claim to the distinction, is a very fishy river and gives much sport, like another member of the family-the one which is fond of wandering over Huntingdon racecourse and which, down by King's Lynn, has fine stretches for boat-racing, though a very muddy-banked customer, as I suppose nearly all tidal streams must be.

Correspondents have been kind enough to write giving descriptions of canoe voyages made over the course I mentioned recently as now impracticable - viz., from the Thames to the English Channel by way of the Wey and, so far as practicable, the Wey-Arun Canal to the Arun River and so on to Littlehampton. No doubt the logs would be read with interest, but you can hardly be said to navigate your boat from Surrey to Sussex when, instead of carrying you, it has to be carried; but still, one good turn deserves another, and though hoicking a canoe about on land is bothersome if you feel it that way, and struggling through weed and reed beds toilsome, especially when you are in any sort of a hurry, you can make good fun out of the work. While thanking the gentlemen for telling me how the transit has been engineered I feel that I ought to put in a word of caution for general benefit. I do not say anything about contingencies attaching to getting yourself and craft across country which in parts involves trespass, always likely 
to lead to differences with unsympathetic owners or holders of land and their representatives. You must do your best to get out of such scrapes, which do not matter much supposing you, being in the wrong, take the right course and acknowledge yourself so. What I do wish to point out to friends who may be induced to follow the lead given by my correspondents is that voyaging on the Wey is a business which should only be taken in hand quite seriously, because the locks used to be frequently awkward to dangerous degree, and I believe this is still so. You, as a rule, have to work them yourself. Accidents at these were of common occurrence, and are very easily brought about. It is a pity that the Wey canalriver-I fancy this was the first stream converted into a canal-should be made or left to be difficult for transit; but so it is, and bearing in mind how people get into trouble for lack of a friendly hint, I now give it.

Some day we shall, I fancy, want to restore many of the canals now fallen or falling into disuse more or less partial or complete. These waterways might be brought once more into profitable use. A curious thing in connection with some of them is that their natural enemies the railway companies who by hook or by crook took them over pursue so strange a policy in, so to speak, strangling them as nearly as possible. Though saddled with responsibilities which old Acts of Parliament enforce, the new proprietors go to work to starve the water traffic as much as may be instead of trying for profit. We know all about the ancient argument re the balance of increment between the swings and the roundabouts, but I fail to see why, in order to raise 
the profits on the railroad, the directors should lay themselves out to lose by their canals. Still, there it is. They do so, just as the trunk lines have many a time starved their feeders, the tributaries, little local companies, till their shareholders capitulated and turned them over to the big company at woeful loss. You would fancy, would you not, that what was good for the small company would be so for the great also? 


\section{CHAPTER III}

\section{PATCIHING AND SELSEY}

Iт has been thought strange that the Goodwood programme does not include a stake named after Lord George Bentinck. So it is, considering what that nobleman did to put the establishment in order for training and racing purposes, and his family connection with the lords of the land. To me this sort of Turf nomenclature is a good and fitting thing, stamping the connection of races with men, also when the same idea is carried out localising, if I may so term it, the programme with the neighbourhood. Epsom's card abounds in names of notables and localities. Lots of villages stand sponsors for its numbers, and pretty work it is for one interested in the game to follow up the hints given in the programme. Maybe, when work is easier, and one can put more than twenty-four hours into one day (and every day), you and I, friends, will have a round, starting from the Goodwood bill of fare, and see what we shall see. Plenty of good amusement can be got out of the business, and I may say that when you can start to do the sort of thing honestly, really visiting the places, fossicking about and seeing for yourself, it is 
wonderful what a lot of little and bigger pieces of history and folk-lore, not to mention the picturesque and curious, you may hit.

The Gratwicke Stakes is cited as showing the strangeness of there not being a Lord George Bentinck. Bentinck would scarcely do nowadays as a new stake, because the reference would be taken as applying to the Duke of Portland instead of to the Napoleon of the Turf, who in some of his methods was very Napoleonic indeed, seeing how exhaustively he believed in Heaven's helping him who helps himself to what he wants, as witness the style in which Red Deer's Chester Cup was engineered. A game like that wouldn't be stood at an unrecognised flapping meeting in these enlightened times. Certainly there is more call for a Lord George Bentinck Stakes than one named after Mr Gratwicke. Was Lord George properly Sussex? I am not so sure about that, though one way or the other that does not affect the classical connection between the great dictator of racing and Goodwood. Squire Gratwicke was Sussex as Sussex can be. He lived at Ham Manorwhence, I presume, the Ham Stakes-a very pretty place at Angmering, just off the road from Worthing to Arundel, and only a bittock from Patching Pond, the name of a village not far from which used to be a decoy. Patching Pond lies about half-way between Angmering and the most charming training quarters, formerly William Goater's, at Michel Grove, later Halsey's for $\mathrm{Mr}$ J. A. Miller, and later still Captain Davies's.

The little inn at Patching Pond, on the shores of the lakelet, is a sort of half-way house between Worthing and Arundel, though you 
have done the bigger half before you get to it. At Angmering, the Ram, a much larger and more pretentious establishment, came in, I believe, for coaching purposes. Of both, as of Squire Gratwicke's park, I have pleasant memories, dating back I must not say how many years, and in the beginning built on an unprofitable system of economy and thrift. Once upon a time I lodged, not my banking account, but personally, with an old stiff-backed wheelwright devoted to fishing after his kind. Nothing pleased this honest man more than to be angling in his way, as I said before, and I invented a scheme to gratify the good chap. We-he was in it so far as distribution went-started a money-box as follows: each night I cleared my pockets of all coppers and banked them. Unless you have tried this dodge for founding and filling a stocking you could never believe how the mony mickles bulk into a quite appreciable muckle. As soon as the latter had sufficiently grown, off we-self and the wheeler-would be to Patching Pond for a day's fishing from a rather leaky old boat on the reed-bordered waters, and caught perch by the score-little ones mostly, that were put back, if they didn't prick our hands too much with their spiky spines. We divided the labour equally. I caught the fish, partner was in the outing more than the regular fishing line. He was told off to bale out and pour out. The last-mentioned function he performed with wonderful ease, precision, and perseverance. Happy days, or big bits of them, I have spent on that old pond (I call it old in a companionable, affectionate sense), in the sweet air, with no sound except, maybe, a swallow's splashing as it 
dipped; the swans' talking generally of something unpleasant, I fancy, because they seemed ever on the grumble; and the moor-hens giving off their perky little remarks. All manner of little and big strangers would come peeping out of the reeds and bulrushes. I can't call to mind any bulrushes fatter than these used to come in due season. Very, very fascinating all this was, and I never could tire of it. Neither did he, the wheeler, who used to study the creatures' ways, tricks, and manners, and take in the beautiful little mise-en-scène to such an extent that he invariably on warm days fell asleep, not seldom dropping the corkscrew overboard in the process. I wish the old man was about now, and I with him in the boat, the one in which we cramped our limbs, and called the suffering all in the day's pleasure, or any other boat so long as I could have one more spell of perfect restful peace in pure air, with an excuse for pretending to be occupied, and not forgetting the corkscrew section of the business.

Here, you say, where on earth is the connection between Squire Gratwicke and corkscrews? You do, do you? Look here, now, and I'll tell you how the links come along. Patching Pond, the village, is only a step from the squire's old home. It happened that the owner of Merry Monarch, winner of the Derby in I845, was a real good sort. (Half West Sussex was concerned as claiming in a massive law suit when his estate was to be administered. This I mention not as proof of his moral worth, but because the incident occurred to my memory at the moment of writing.) At different periods he had set up, as was formerly a kindly patriarchal 
fashion, retiring butlers and coachmen in the local houses, the Ram at Angmering, and the Horse and Groom aforesaid at Patching Pond. I fancy Merry Monarch was the racehorse which Herring painted in "The Start for the Derby." Moreover, it was a custom with local worthies of this class to give their former dependents a turn by making themselves customers, occasionally calling with friends to partake of light refreshment. Naturally, good stuff-frequently of the patron's own selection or purchasing-was kept in stock for occasions when the great folk looked in, wine far above the character of the inn's ordinary trade. Of course the day would come, as it did with $\mathrm{Mr}$ Gratwicke, when patron and client no longer were concerned in the drinking or vending of good wine. (I saw Mr Gratwicke's wine sold, as also the Merry Monarch picture, so well known to most interested in racing, though many are not aware whose year it commemorated, nor that the start was drawn from behind, not in front, of Sherwood's, formerly Sir Gilbert Heathcote's, cottage.)

With the special customers dropping out, all call for the good port, Madeira, brown sherrydry had not then been invented, I think-and sound full-bodied claret ceased. After the landlord and his wife, maybe, had followed the old master, these stores lost their identity. Scarcely any wine trade attached to the premises. One tenant after another would in succession have the stock valued to him, taking it over as "changes" were worked, and there the stuff would lie in the cellars unless somebody happened to call for a bottle. Then wine almost unbuyable from anyone who understood its value would, I regret 
to say, be wasted, absolutely thrown away, at the standard price, three and sixpence a bottle. Alas! I found some of Squire Gratwicke's magnificent port being put on the table at a beanfeast at Angmering. The landlord, a cranky kind of fellow-one of those who call themselves "independent"- -declined to deal for what he had left of the good old comforts. While it was there it would save his having to buy any more. What could a bit of a judge do under the circumstances? I know what I did, the best possible in face of his determination-or, rather, we (wheeler and self). We went a-fishing whenever the funds were flush, and drank all we could for fear that someone else might come along and selfishly mop up our own private particular bins. If anyone had known of the precious stores earlier it would have been almost worth while to have become a landlord pro tem., so as to get hold of the fine stock. "We are not asked for a bottle of wine once in a blue moon," said one of the holders of the unknown treasure. He was, though, when we tumbled on to the tap all along of its being the wheeler's birthday and his insisting on standing a glass of port, a sample leading to seriously coveting our neighbour's cellar stock.

Don't you go starting off to West Sussex, good readers, under the idea of touching a vein of stuff as we did. At the old-fashioned inns that were you will nowadays probably strike a wine card, with all the items supplied from one tied-house squeezer's cellars. You have in a general way as much chance of picking up the right sort held through accident as of coming by genuine sporting prints. All the same, you can become the fortunate possessor of as many 
wrong 'uns specially planted for you and your stamp as would fill an Atlantic liner.

Clearing, pro tem., for once from Goodwood's immediate vicinity, I did a bespeak at Selsey one July. A subscriber from the first, a lady subscriber too, and an invalid, sent the Referee notice that she would take it as kind if I might be told off to do a walk for her, as she was unable to take one at first hand, alleging that rambling notes did her good. So, by way of providing a tinge of novelty, I went in for a short course of Selsey, which (the course), the way I took it (by tram), carried some of the most striking features of rough sea voyaging, barring stewards and fixings. During a journey of eight miles all told between Chichester and Selsey on a light steam tram line you had the lurchings and rollings, the gradual sideways, sinkings, and sharp, jerky recoverings, the temporary poisings on nothing, which frail support appears to melt as you dip, and the general sensation that the part of you believed by the Chinese to be the seat of the affection was capable of shifting to anywhere between your brain-pan and knee-caps. Never was anything more realistic than the imitation of mal de mer exhibited to your humble servant, and all for the small sum of a bob return, and cheap at the price.

Selsey - a flat ledge, a little above high-water mark-is now on my list of places to be done at length as soon as occasion offers. When will that be, I wonder, and will Selsey be on view when I want it next, also the at present lucky folk pitched there in houses and bungalows of sorts, with a cape between two half-moon bays and a charming view, with lobster pots in the foreground, which- 
ever way they please to look seawards? There are, as objects of interest, two churches, Established and Primitive Methodist, a liberal supply of hotels and fresh, clean inns, a beach pebbled almost exclusively with white stones, a roomy tin refreshment room, boasting for only signs of civilisation and occupancy a draught-board lined out on a table with a knife, and played on with clinkers for the black men and the aforesaid white pebbles to represent the white warriors; a lakelet tenanted by a sunken canoe, and a receding foreshore in places sought to be protected by $\mathrm{V}$-outlined groynes that on a cursory glance looked more likely to help the sea in its encroachments than stay depredations. A lovely air was on, and a little lively breeze, making the sea popply, ideal water for swimming. Along the coast ran a wisp of spray, rising from the waves' gentle fall between breadths of bright clear sunshine. Overhead was a sky of blue deep enough to satisfy a captious Australian discontented with the English climate. The dowdiest old tan sails, grateful to the eye, showed by this light well-to-do in the distance as the whitest of the "white wings," conventionally reckoned a proprietary article for the Solent. Selsey's little fleet a-lying at anchor, backed by a salvage galley ashore, made quite an imposing show for numbers, not tonnage, and the railway carriage bungalows came out absolutely smart, though, of course, not to compare with the best of all the collection of low houses artistically thatched in style to make you cast eyes over the water to where Shanklin would be in the Island according to your reckoning and its thatched cottages. To the East along the 
littoral stood out Bognor, and were to be identified bits of Littlehampton, also Worthing Point. Farther you might really be seeing Beachy Head when you said and thought you did, and very likely your range didn't carry so far by a long way. But there was no mistake about you being able to follow the lines of the Downs farther in that direction than Chanctonbury Ring; and the face of the highlands from Portsdown through Goodwood, Halnaker, and Highdown-where you know the Miller's Tomb is, if you can't see it - to the range east of the Adur makes a pretty panorama. Round the point, the crook of the Bill, I suppose, by the Marine Hotel you command a run to the barracks on the Hayling side of Southsea Common, and there is the Wight with, glaring white in the sun, the great chalk cliff, which makes you say to yourself Eurydice, and not want to think about it again.

What a time I could have had, to be sure, taking in a bit of bathing and boating and admiring the wild spinach that, with the yellow horn sea-poppies, sweet little convolvuluses, dwarf nightshades, and other persevering, struggling colonists, will soon clothe the barest shingle beach and make their own soil to grow in if they once effect a lodgment. The hard-working fishermen, too-civil chaps, with no trace of the mouching longshoremen about them, wouldn't they be aids to real holiday-making? My word! they would so, and I have not cited the greatest charm of all that took hold when that I was and a little tiny boy, and is strong as ever now, though I never told you about it, good readers. Well, you must know that even in midsummer Selsey's 
flat coastline is pretty lonely, and if I have a mania, it is for treasure-seeking on the sea-shore. From force of habits displayed by writers for the young and upwards, I have learned to expect palm trees chucked in and a coral reef, not considered as an extra, laid on for seeking in good form. But if palms and corals and wrecks are "off" I can do without them so long as the shore is there and I have a fair chance of besting the Lord of the Manor and the Crown and the Lords of the Admiralty, the underwriters or original owners of precious flotsam, jetsam, and lagan that comes my way cast up by the sea or hidden by, for preference, buccaneers, homicidal volunteer fleeters. All or some of the powers named might, you know, want a corner if you discovered treasure too openly. That is why I prefer a lonely coast like Selsey's. But, lonely or lively, in the sense of being populous, all are alike to me, for search I must, buoyed up by faith in somebody's shipload, or part of it, coming home for me before I give up treasure-seeking, which, I give you my word, is (the seeking) a thing I have never once missed doing on any sea-shore I have trodden. As it was, at Selsey I nearly missed the return tram and a second dose of land-on-sea sickness through straying farther along the beach than time really allowed, and satisfying myself that what looked like an old broken boat-side-and was such, too-was not treasure in disguise, and so was obliged to scamp the village in hurry to get to the tin station. 


\section{CHAPTER IV}

THE DOWNS IN WINTER

Naturally, when I wanted to expatiate to strangers on the uplands and downlands commanded by Chanctonbury Ring where it towers above Steyning, we found a fog. Perhaps not unreasonable in February and a hard frost; but somehow fog has almost always happened to me on occasions permitting a visit to that living memorial, a landmark with which everybody almost who has been in Sussex is acquainted, for which we and the countryside have to thank the Gorings of Wiston. The frost having thrown me out of work after a fashion, because of stopping many sports, by way of making overtime, I paid half-holiday, part business visits to the yuadrilateral-or something like that it is-shaped range of downs bounded on the east by the Adur River, the west by the Worthing-to-London stagecoach route, and the north by Weald, and southwards, trending to the sea-shore, are West Sussex lowlands, some salt-marsh, some of higher level, where the fig tree ripens its fruit in the open, asparagus brings itself on early, fruit trees generally flourish exceedingly, the best of sea-kale and tomatoes reward gardeners, and, as a good lady, 
somewhat enthusiastic in territorial prejudice, favouring her "native"-this is Sussex-declared, if you planted a broken-down old cap-shape it would come up a best bonnet all over flowers. Had my feminine authority (deceased before latter-day palatial creations perhaps too extensively and outwardly adorning the fair sex) returned in these days, she might have hedged a trifle, though, from what I knew of her, I fancy she would have stuck to what she said. Anyway, if erring a little on extravagance's side, she was not far wrong, for you can grow anything down Lancing, Sompting, Worthing, Broadwater, and Tarring way.

But let me get up from the belt between the hills and the shore to the breezy plateau whither I have on four memorable trips guided friends into the mists seeking views and finding none. "They are skating," said good Mrs Cuddington, at the little inn facing old Shoreham Bridge. I always pay that roadside hostelry a visit out of respect for the proprietor and better-half, also to show friends the massive wood tables a former village blacksmith used to raise to the ceiling-a low one, mind--with his brawny arms. Said arms' muscles must have been strong as iron bands if he performed the feat, as tradition asserts, with a palm under each. "They are skating," said Mrs Cuddington, and, says I, to brother visitor, "the way we strike across to Findon we shall see very lonely ponds, and I will bet the boys have spoilt the ice." That I knew was as sure a thing as an explorer finding an uninhabited island's lakes lined on the bottom with old coal scuttles, no matter how hot the climate, and our running into fog as soon as ever we won to the 
top of the down range. The pond just by the Chanctonbury Ring is one of the most out-of-theway. I wanted to inspect that which so long as local memory serves has always helped itself to plenty of water, taking toll from clouds, dews, and rains. That, however, we were destined to leave unvisited because of the mists-but another sheep-pond, almost as remote from the madding crowd's beats or runs, also ignoble strife, was being decorated, a shepherd's boy heaving stones, lumps of chalk, and bits of turf stubbed out by his heels on to the surface, just thawing for the time. Wonderful, is it not?

Holiday we were making and holiday we made, because we were there on purpose, also the best of what we could see between Findon and ever so much farther east. How far east we were when a hawk as big as an eagle occurred I won't say, because if I did so much as hint at the locality sportsmen might go to slaughter the creature. The bird may have been a real eagle, his size was so great. A couple of rooks who resented his company as an intrusion were to him or her in like proportion as the little birds who heckle a sparrowhawk are to that small highwayman, so you may guess what a great fellow our specimen was. Of views we had none-no grand outlook over the sea, no proper comprehension of the high hills and deep dales, no pleasant feel in footing it on the turf, which was frozen iron-hard, nor pick-me-up touch from the glorious, strong air in which the hale and lung-sound ought to live for ever-a tonic the weak should take as a sure curative worth a guinea a bottle for home consumption, and cheap at that.

Good old Sol did his best to beat the bitter 
wind and make Nature's face cheery. But $\mathrm{Mr}$ Q. S. was a bad second to spoil-all mist and fog, which, I declare, tasted of the great metropolis fifty miles away. Lapwings, fieldfares, partridges, larks, linnets, yellow-hammers, or ammers - which is, I believe, more correct-went about in a forlorn, chilled-to-the-bone, influenza patient's despondent manner. Even the seagulls seemed too much depressed to quarrel with each other, as is their wont, and the aforementioned pair of rooks, only members of their tribe on view, settled down, after annoying the hawk or eagle off the premises, as if the domain they had been protecting was no good to them when it was left to them to do what they liked with. The hares were unapparent, apparently frozen out, and the out-of-sight conies frozen in. Cissbury Hill, with its vast castrum, fosse, and vallum, loomed ghostly in his gloomy height, and the training gallops were by comparison comforting by reason of hoofprints, reminders of life and go, more or less recently recorded, even if work up to date on them was as impracticable or inadvisable as galloping horses round Admiral Nelson's column in Trafalgar Square. All vegetation was frostbound, down to the fuzzes, with never a yellow blossom to remind you of kissing's being always in season. The stunted thorns might live, but looked very dead indeed, and past hope of being once more sap rising, not to think of ever again coming white with blossom with spring's fountains playing again. The only touch of warm colour came from the mosses' golden-brown flower or seed stems; and a farm labourer in amphibious get-up-seafaring down to the boots, where agriculture asserted itself through weighty old 
mud and muck-stained high-lows-was so out of sorts and despondent as to lose all sense of locality and direct us altogether wrong.

Not much of a holiday, eh? Well, things might have been better, but might have been worse. Self and partner might have lost ourselves and been discovered mere remains when the frost broke up or the fog lifted. One of us might have sprained his ankle and the other had to carry him if he could, and neither of us twain might have reached-as at length we didWilliam Goater's old training stable, where John Porter was a long while, later Fred Barrett's, and now claiming $\mathrm{Mr}$ Bob Gore for master. That might have happened, and might-indeed didnot, for we fetched these hospitable quarters all right, and were sent on our way rejoicing in the turn of luck to renew acquaintance with Steyning's White Horse and the sausage-making butcher opposite-none better. Later, the light was good but the going awful. We had to blunder along, slipping and slithering, half-thawed, frozen clayey paths and byways, and so under the hills through Edburton and Carrington, with its sparkling spring rivulets, to the Royal Oak, Poynings, where is purveyed a strong alemighty grateful, comforting, and staying on a cold day, and a credit to the local brewer. Then we fared by way of Squire Gurdon's at Newtimber, in whose family history is the story of a steward's murder over by Pyecombe; Damny Park, home of the Campions, of whom in their connection with Norton Folgate and the West Indian rum and slave trade Sir Walter Besant wrote so pleasantly; Clayton, whose tunnel calls to memory a direful smash; and pleasant 
Plumpton, for once robbed of a day's racingcoursing it was to have been this time-to Lewes, and not a bad holiday scored after all. We had been on ancient bridle-paths and packhorse tracks nearly all the while, and in almost as old forgotten country as $\mathrm{Mr}$ Far-from-theMadding-Crowd Hardy might find in his Wessex.

With a view to further excursions round about Chanctonbury Ring I proceeded to prospect from Steyning. I know of no more representative old-time Sussex town than this, with its many quaint, ancient houses, rag stone-slabbed peaked roofs, half timbers, and quiet, take-it-easy air, for which I am not sure whether the inhabitants or their dwellings are the more responsible. There is a venerable church in Steyning and a river, not gay, but still a river, the River Adur, handy-two very desirable things in my eyes. Walled gardens are, so to speak, built into the town, and though what is called improvement comes, and expansion by way of extra rateable eligible property, the expanding is mostly done outside the old part, so that you get genuine large-sized instalments of unadulterated antique all in a piece of some two hundred yards or more at a time, instead of the native being all mixed up with modern townhousy samples.

Now take some downs farther east, under an equally wintry but very different aspect. Come out of the London and low-lying fog which is so apt to spoil Christmas into fresh country air, brisk and snappy with frost, under a clear sky, worth a pound a minute no matter whether you could afford the luxury or not. Finding the 
right brands, I made for the pleasant holding under the hills at Plumpton, the place, or rather at whose Place-the Place with a capital Pcarp and golden pippins first occurred, so far as England is concerned. After the filthy fogs one was indeed well off to strike a spell of any sort of decent weather, a piece of luck not quite achieved, for Plumpton, like London, had its thick mist-not a poisonous one, but a view obscurer and unpleasant to the "pipes." There was I on an afternoon in late December set at liberty in the betwixt and between time, just before the sun went down and the moon came up, as they did, dead-heating vividly in the process, at the end of a little trudge from the race-ground to the top of the high ridges where lies the plain on which Simon de Montfort and Henry III. fought. I was very nearly monarch of all I surveyed from the crest of Plumpton Borstal, drinking in draughts of frosty air by the chestful, and bound for a cruise across country towards Brighton. A charming undertaking this is not for anyone at all nervous or a trifle indefinite in geographical information. Chance of going wrong in the dusk that was creeping on, despite two great glares east and west, was not to be put quite out of mind, and added to the expedition that tinge of excitement supposed to be desirable; though, personally, I would rather be without even the most distant prospect of lyingout all night on hilly and daley uplands with not a ten-thousand-to-one outside hope of coming across a soul; but to make up for that, very great probability of wandering over a chalk pit or, minor evil, coming a cropper every few yards as you got among the furzes and thorns, or on 
the frozen grass, spongy with rime where the growth was thick and like a greased slide on the open patches.

The family of $\mathrm{Mr}$ William Burbidge, who trains just outside Chichester, have been in the training interest about Sussex for many years, as also up Epsom way. I recollect Mr Burbidge's father at Smitham Bottom, where was and is the mile on the road almost as celebrated for foot-racing as any of our latter-day grounds. Captain Machell ran on this mile, and all manner of peds., high and low in degree ; but I was bearing the Sussex part of Mr Burbidge, sen., in mind, not the Surrey. What I was going to say was this. His son was at Plumpton; some seven miles-or, perhaps, eight-away as the crow flies is Telscombe, a mile from the sea cliffs, a hidden hamlet very difficult to find by the uninitiated, unless you accept a self-evident tip and stick to the line of a telephone wire originally put up for $\mathrm{Mr}$ Joe Gubbins when he contemplated settling down a team of horses there. For him were the stables occupied by the late Edwin Parr (trainer of Lord Clifden) greatly enlarged and extensive alterations made. There it was that the great scare about Lord St Vincent's horse arose. I suppose that someone really did try to nobble the horse. I wonder whether he was by Newminster out of The Slave? The pedigree comes to me automatically, but he won his Sellinger in I 863, and that is forty-one years ago-a long while. The story of the nobbling, which did not come off, was diabolical. According to it, some villain, or villains, removed a patch of turf in the gallop, scraped out the earth under it, and replaced the sods over sharp, jagged flints, 
hoping that Lord Clifden might strike on the spot and get a foot through. A mighty pother there was about this, as well could be, but not a percentage of the sensation special editions would work up out of such an incident nowadays. Why, it would keep them in headlines for a week all of itself.

In ${ }^{8} 863$ I did not know so very much about going and so forth as I do now. Looking back to the nobbling, I take it that one might safely bet on there being a wettish period when it occurred, or that trainers and owners were content with going their successors would not look at. Mr Gorham, who has had the Telscombe gallops in hand for a good long while, has laid out a lot of money on making them better, and, I may say, made things better for the people all round. Like a good sportsman, he does for his 'chasers what would make hunting's life last a deal longer than it willviz., buys all the fodder from the farmers and considers the neighbour folk in every way. It would have been a bad day for Telscombe if the military scheme took effect and in its process knocked out facilities for training, thus driving the horses away. We hear a lot of talk about manœuvring on turf without damage. Those who talk that way do not know, neither can they conceive what the highroads would be like in a little while with the heavy steam hauliers at work grinding up the macadam surface. Not allowing for such wear and tear as must accompany dragging guns and siege trains about, it is a well-known fact that though liberal treatment in care can do a deal for these downs, you cannot make them the sort 
of going in summer one wants for swell flatracers unless you are favoured with plenty of rain or a succession of heavy dews. What you can do on the downs near the sea if you turn out with your horses very early-which is to say, before the dew, mostly from the sea, has evaporated-is surprising. All the same, I cannot see an experienced trainer taking a Derby horse there.

A goodish while ago, but not so very longit was just when my old friend $\mathrm{Mr}$ Gubbins had taken possession, with Vasey for trainer, and there was a good deal of unreadiness about the place-I walked over there from Brighton on a day after the corresponding Plumpton meeting to this just held. I shall never forget the impression the menagerie gave me. There were self and a 'Varsity steeplechase winner, his brother, and a fourth. We arrived at two in the afternoon, just looked round, and came away again in about an hour. All we saw of the horses was old Spahi, with a leg about the same size as his barrel, some more 'chasers up to very little, and a little string of yearlings - to be two-year-olds in a few days. Now, such a collection does not afford much scope for "brussling," does it? One of the young 'uns was brought out by itself on account of being bad mannered, and, in hope of its becoming more tractable, was sent over to Telscombe for the mail. You have to go three miles from Telscombe to buy a glass of beer, you know; and Rodmell, its post town, is about as big as Bolt-court, Fleet-street, throwing in the little pub. of the village, celebrated in a former landlord's time for home-made hop-bitters, its windmill, the stock-in-trade of a dealer in appar- 
ently busted-up agricultural machinery qualifying for scrap-iron; also the church on the edge of the marshes, otherwise brooks, where a tired body can sit in the summer sun and absorb peace from the surroundings, while the children sing in the schools next door, the cattle low on the marshes, and the local birds, with proprietary interest in the church and churchyard, size you up -I trust returning a favourable verdict.

If you wanted to go to Telscombe from Lewes you would surely be instructed to make for Rodmell, "where anyone will tell you the way." Perhaps you will find this anyone, perhaps you won't, unless you think of making an inquiry office of the inn, and when you are told your way, you are by no means sure to fetch your desired destination. Before this, I have quoted the directions for discovering the place as given by a Lewes trainer: "You won't get there at all except by accident, and you will know the place by putting your foot into a chimney - that will be Telscombe." I was gossiping about a visit during the Gubbins regime. Well, we saw the bad-mannered colt dispatched to Rodmell for the letter-bag, toddled up on to the gallops towards the sea -the village is in a little cup in the hillswatched the yearlings do some pottering about, wished the trainer a Merry Christmas, and marched off in good order on the way back to Brighton. What do you think came of our friendly call? Somebody wired to authority to report the presence of four more well-known touts-Self and Co. were the brussels sprouters -and the stable-boy who carried the letters on the troublesome young 'un was charged with 
taking news from us for a big bookmaker. We had only gone there because some of the company refused to believe in my yarn about Mr Burbidge being feasible-an anecdote I set out to give miles back, but once I am going on the downs I never seem able to get off them again. (I never would, if I had my choice and a handy house to live in.) One foggy evening Mr Burbidge set forth from Lewes to go home; to that end he rode all night long, determined to find Telscombe; but did not until daylight did appear. This is true of the old gentleman, who thought he knew every inch of the land, every cart-rut, flint on the turf, and blade of grass.

His own version was that he might have been riding round Telscombe till kingdom come and not spot it but for daylight; and what is true of that locale holds pretty much for the whole tract. Once you get off your line ever so little in the dark, or even dusk, and goodness only knows where you may not stray to. As I was a-saying, I landed at four in the afternoon on the crown of Plumpton Borstal-next-door neighbour but one to the highest point in the range, Ditchling Beacon. I should say we landed, for a game little toddler, an ex-steeplechaser rider, was with me, as also a sort of unattached companion, an old soldier of twelve years' service, not so very much more than twice so much in age, and no pension at all, a Lanky Lad from 'Owdham, who had served in India and South Africa. Down in the Weald I heard my gentleman asking his shortest way to Brighton, and being locally directed to "Go up to the top of that road on to the downs, turn to the right till you get to the telegraph wires, and follow them till you get to 
the town." All very well this for one who knows, but likely to lead to trouble for the stranger, since as soon as the light failed he might range about till he dropped before he did strike the telegraph or, what is the same thing, the old coach road from London through Ditchling to Brighton. So I suggested that it would be safer to come with me, a proposition he scorned on the ground that my division could not go fast enough to keep him warm.

All the same, he didn't mean getting out of touch with us, and a good thing he didn't. As a matter of fact, he did not know what Downs were. They might be the Downs of Deal, for all he knew; and when he first beheld what I rank as the most beautiful country of my experience (Tommy Atkins mentioned the Himalayas, which were not admitted for comparison) they came as an appalling revelation. They were too much for him-the silent ranges flecked with white patches of hoar frost, hills upon hills slipping down in outline from the sky to the bottom of the valleys, making a sort of herring-bone stitch crossing of gently slanting ridge across ridge, all almost identical in ewe-necked fall, and gloomier and more impressively mysterious as they almost faded away from recognition in the distance. Behind was the moon rising over Black Cap, a burnished copper disc more glowing than many a setting sun. Facing her was the sun dying out in an orange and pink glory, the two between them making a remarkable effect with a shadow cast backwards and forwards at one and at the same time, an event to be remembered. Never did my favourite haunting ground strike me as more romantic and precious 
a bit of prehistoric country almost untouched in the centuries since the chalk waves were formed, no scientific man knows how. I could have wasted quite a lot of time taking in the strange changing aspects, for the tints went out to greyness as the sun dipped into the sea, and the moon, clearing the vapours, gave out its white light, cruelly cold, the colour of a chalk-hill blue's wing, but dwelling was not advisable if you didn't want to be caught. Moreover, the soldier man gave a strongish hint. The overpowering solitude had knocked all the Tommy self-sufficiency out of him. "Is this the downs, mister?" he inquired rather anxiously. "Yes," says I ; " and the man down in Plumpton told you to turn off here and keep to the right." "'Strewth," he says, "I don't turn off nowhere nor slip you till I'm on the hard road again."

He was a man of his word, and a wise one, too, for the way was difficult, and not made more easy by our finding the gates of Lord Chichester's park locked when we came to that last link in a short cut and were obliged to climb a hill like a church steeple, all ice and slippery, so that your feet went away from you, and your nose rubbed itself painfully on the cold grass or mole hills' gritty surface. However, by hook or by crook, we made shift to go round where we might not get through, and arrived latish at Falmer Station, whence I dispatched the warrior, forepaid and the price of a drop of beer over, with suggestion that if ever he was this way again in summer he should test the downs' charms. The poor man had no eye for the picturesque-at least, not if I may judge from his reply, "Not me, never again, winter nor summer; not if there was an electric 
light every ten yards and a licensed house every quarter of a mile." So we separated on a point of incompatibility of artistic perception, and on my way back to Lewes I called to pay my respects to Falmer pond, on whose ice I once skated all day on the fifth day of November. That was the year after Inkerman, and there was only one night's frost. I do hope that the new Lord Chichester will try and restore the old regulations under which the men on the estate were able to look on a long frost as a blessing, because they were given possession of the pond to sweep and keep in order, being rewarded by a liberal collection. Besides, the Brighton roughs were kept off and the right people got the money. 


\section{CHAPTER V}

\section{BRIGHTON TO NEWHAVEN}

ON a fine day in February I took the air in what I consider very beautiful country, when I proceeded to Brighton to inspect disappearing Black Rock and the racecourse. The long part of the track-by long I mean the portion more adjacent to the old Cup start-answered the conundrum, When is a Brighton Racecourse not a Brighton Racecourse? with When it's a Kemp Town golf links. Poor crumbling Black Rock presented a puzzle also, one very difficult to solve. That the line of cliffs right along to the east of the borough must be damaged more and more severely as Brighton groynes its sea frontage, was always self-evident. As a matter of fact, no one can afford to be idle in such work while his neighbour is busy making groynes. The tide is bound to curl round and eat in next door to begin with, and right along, too. Now, just at the most insidiously attacked piece of the cliff, whose being undermined by the sea was a mere matter of time -and not much of that, either - the land's end or face to the waters and wind and frost, rain and snow, consists of a big pocket of naturally crumbling, half decomposed, loamy chalk known as I 52 
combe rock, worth a lot for path-making, because it sets so well. Beneath this is, in this particular spot, a bed of chalk. All above this bed has to slide into the water and be wasted, or can be raised landwards, and so become a gold-mine in a way. What puzzled me about the matter was the owners practically making a present of the stuff to the sea. Moving it landwards cannot accelerate the elements' destructive work-a sharp frost and a shower of hard rain to follow can bring the valuable material down by the hundreds of tons.

Farther inland was the great puzzle round about which I was writing before. How is ithow the devil is it? - that so magnificent a playground as the Downs constitute are scarcely noticed? Going inland, for, say, five miles from the sprint races' start, not one man, woman, boy, or girl did I meet, overtake, or see about in the offing. What were Brighton's two hundred thousand or so residents and temporary visitors about not to get out in the sweet air and on the turf? Goodness knows we all hear enough railing at the dirty weather! Per contra, can we expect a Clerk of the Department to turn on bright sun, balmy, comforting, placid warmth, in a Morland blue ground and a Constable white fleecy clouded sky if his customers, so to speak, make no use of the treat? Not one single solitary soul took his pleasure out of the supply where I was. Spring might not be coming in or have any harbingers at all so far as they were concerned. There were we, the furze chats ("fuzz chaps" shepherds will call them occasionally), a few stray yellow-hammers, or ammers, styled in parts squibbly larks, an odd jackdaw or so, rooks 
mostly lurking about in very small bands, and never a seagull for a wonder-we were there with the place all to ourselves. Down in the hollows of the valleys, punch-bowls, or combes, where are here and there "deans" with a prefix (as Stang, Pang, Oving, and Rottingdean), were now and then furze-wattled folds for the ewes, whose bells' tinkle mounted tunefully from the hill spurs to the ridges. An unusual yet welcome sight presented itself here and there-viz., Scotch cattle helping dress with life some of the ranges' sides and not before they were wanted, to get the long self-saved grass off, and make a chance for the coming young growth.

That grey, pearly, only slightly opaque, mist seldom absent from the chalk country magnified distance and proportions magically, bringing about romantic, almost grand, effects, so that if you knew no better you might fancy yourself in a land of mighty mountains instead of mere downs. Between the crests, peeps at the sea relieved the (alleged) sameness of slope piled on slope. Here and there the beach and fur spinnies bulked far more important to the eye than their real size warranted. Stanmer Park shaped a great forest, and the Dyke a big settlement miles and miles away. From Lewes Race Stand over the way the land climbed and climbed till Ditchling Borstal was almost in the clouds with Mount Harry's comparatively mild eminence, a peak or pike carrying quite minor distinction. Across the Ouse's estuary, the sears on Seaford's golf hill almost blazed as the bright white light caught it. Newhaven harbour's masts and funnels, not forgetting its giant spidery shear legs, was to all appearance nearer twenty than half a dozen miles 
away, with lakes and lakes of flood-water flanking the bank-full river, now, for the most part, of one tide only - a perpetual ebb dominated by the force of land water. Greater than ever I saw it before appeared the gulf across the brooklands, overlooked by the tall sentinels, Mount Caburn and Firle Beacon. Splashes of red on the lowlands told you of the buckthorn's twigs, a rosy-apple lake colour; minor tones of woolly effect in grey and brown spoke of tall trees risking frost's attacks after the fashion of an imprudent mortal tempting Providence by shedding his overcoat on the faith of a midday winter sun. You knew that away on the "brooks" "borders the lords and ladies were peeping lettuce tree green to the general's olive leaf tone; the guelder roses' flat-headed bunches of blooms, in evidence for weeks and weeks, were ready for an early call ; the primroses, starting in the warmer bands between the downs' feet and the rim of the weald and the birds househunting for eligible building sites; you needed no prompting to note the blazing lichen gilding slate roofs, tile roofs, flint walls, all wrought wood that faced southwards, and live woods, too, even setting up instant contrast with the gamboge of the hawthorns - a tone the May's own monopoly in vegetable nature or art.

Lots and lots of "details" good to forgather with were on view or to be had on the ask-for-itand-see-you-get-it system, and nobody, not a soul except me, the birds, and bunnies, who kept mortal close, there to draw on them for satisfaction. Ought not somebody in the Parliament House to make laws so that such waste might be prevented, even if the force had to be called out to collar His Majesty's lieges by the scruff of the 
neck and compel them to take the goods the gods provide them with no black-care-to-follow company? Mind, I write as I do from a sense of duty, but I should not be a little bit pleased if they came by twos and threes, as in the pathetic ballad of the "Love on Saunders Hall," not to speak of "swarms." The available population's indifference and laziness is lamentable. At the same time, I remember my painter friend, who lectured rustics on the parsley fern's charms, "instead of which" the yokels tore every scrap out of the walls where it grew, boiled the take like cabbage, and cast at their self-elected educator hard names and hard stones as well. All the while I recommend others to do themselves a power of good free of cost I know that the whole game can easily be spoilt. Still, I thought I would put in a word in season while I had a chance.

Newhaven, Brighton's unfashionable neighbour, is a rare nice little place taken right, and would be ever so much better if Brighton was not allowed to poison the coast to its (Brighton's) eastward. A capital (capital if you make allowances) tidal river flows by it, helping at its mouth make the harbour, about which is the perpetual going and coming of ships, the passing of small boats, the snorting and puffing of steam tugs, the cheery sounds of sailors at work, or lumpers loading and unloading, the life of the moving tide, and the sparkle of the sea outside, all so fascinating to some of us, yours truly in particular. Newhaven has not anything like justice rendered it as a seaside resort. A fine centre this is for a fortnight's ranging about the downs, on the river, sea-fishing, and bathing, and do not let me forget 
to give its Bridge Inn a good word ; first, because I have been done there well and economically (kindly understand I am not now discovering Newhaven), but also for the sake of the late landlord, Mr Wright, well known to many racing men as a zealous and able racecourse official, and at home a good citizen, sportsman, volunteer, and jovial assister in all sorts of entertainments. The Bridge is not a Métropole, thank goodness, but a comfortable, cosy, roadside inn, where you can get a bit of lunch on moderate terms (Tipper always in stock), and see the pictorial representation of Louis Philippe's landing, all free, gratis, and for nothing.

I have mentioned Tipper. Are you acquainted with that excellent beverage, a local speciality in ale, local speciality possessed of almost worldwide reputation. Tradition said that Tipper ale was brewed from salt water. History records that, during the times of George IV. and William IV., there was a great consumption of this popular Tipper, which commanded considerable sale in far away London. The last of the Georges to "descend" was very fond of it, and not to know Tipper ale argues oneself unknown in Sussex. Thomas Tipper, its author, achieved posthumous distinction in an epitaph recording among his virtues and accomplishments his knowing "immortal Hudibras by heart," and seems to have been a jolly good sort. He might turn in his grave, the narrow cell on the windy hill-side, where so many "records" talk to you of the sea and East Sussex's roving sons, to hear that, in his very own town, whose celebrated Tipper ale is manufactured still, and sworn by locally at least, the wayfarer "calling" for it was 
made game of. One barmaid wanted the "call" repeated three or four times, and then naturally, being uninformed on the subject, "put it down to" the caller's ignorance, so invited other barmaids to snigger at the poor silly. Still, that didn't matter. The cure was working, the sick man craved, thirsting for ale. Though he didn't get his Tipper then and there, not till the river was crossed and the Bridge Inn reached, hope was then turned into certainty. For, great good sign, he relished the beer, which I defy anyone who has been off colour to do at the first time of tasting unless he is much on the mend. Do we not most loyally recollect how his most gracious Majesty our King did make the nation's heart rejoice when, as the Prince of Wales, he lay at Sandringham sick unto death, as had been feared, and with reason? One almost smiles to remember the vast importance attached to a bulletin announcing that the illustrious patient had asked for, been given, and enjoyed, a glass of ale.

Personally I always look on a sick man's craving for ale when he is just about turning the corner as a most promising sign-if, that is, the party concerned can enjoy it. Now, the person who asked for Tipper and got laughed at was a patient of mine-a Refereader whom I treated for indigestion, and he was under treatment only four days before he convalesced sufficiently to go in for beer, ask for it, see he got it, and relish it, too. His symptoms indicated liver trouble, accumulation of internal fat, and consequent scantiness of soup, otherwise breath. (Singular, is it not, that the slang word "soup" should be so close to the French "soupir"?) Early rising, digging, and sculling in very correct form made the foundation 
of my course. The first cures a lot of things, more especially in the autumn; the second does your garden good as well as the patient; t'other saves labour and enables one to let off steam as a coach. Pull your dyspepsiamatic out of bed just as the air is warmed enough to grow crisp without being too shrewdly "nipping" and "eager," and make him dig for an hour with a spade, being equipped with strong and moderately tightly-laced stays to ensure squeezing the subject's vitals. A fork is well enough in its way, but does not as a rule move so much earth as t'other agricultural implement. Cause the invalid to do his digging in adapted 'Varsity rowing form, with shoulderblades flattened back straight all the time, the stoop being done in the fashion of a wooden doll, and no more roundness of shoulders or spine than you can find in a black-or is it back?-board. Forcing the spade in, levering it, and lifting the mould entails much pressure on the tummy and surprising strain about the small of the back, making fine work for the inward machinery, not to mention the medicinally curative influence coming by means of the freshly-turned earth's cleanly odour. You cure your customer and save paying a gardener wage through this exercise.

Only four days of digging with a spade into the earth and digging with sculls into the water, and being laced into an elegant figure, made a new man of my experimented-on person, partly, as I believe, because of compelling him to stick to most elaborate 'Varsity high home and easy stomach-straining, hip-tiring, neck-wrenching, fixed-seat form or posturing while performing his labours with the sculls. Then I took him for a cruise on the Ouse (be particular about the 
spelling, please-Ouse, not Booze). After sculling down from the Bear at Lewes-good old Bear!-he proved, as I have said, genuine convalescence by going in for Tipper ale.

Before leaving Newhaven I want to compliment Mr Rudyard Kipling on a little touch of his invariable local accuracy. In one of the very, very few Sussex poems ever written, alluding to

"Where beside the broad-banked Ouse

Lie down our Sussex steers,"

he rhymes "Ouse" with "Piddinghoe's." Now I should like to know how many of his readers are aware that that rhyme is, according to Sussex pronunciation, not lame but perfect? The natives-and they ought to know-pronounce the name of Newhaven's little neighbour with the dolphin weathercock as if it were spelt "Piddinghoo."

The skiff-pulling frequenters of the Ouse generally make my blood run cold when I watch their antics. If there is one thing more than another that upsets me it is seeing anybody standing up in small-floored craft. The Newhaven Ouse navigators-don't forget, please, that this is accorded the dignity of a salmon river, and is subject to regulations accordingly-bear charmed lives. They go out in old Thames skiffs and stand up on the slightest provocation. If they want to know the time, they ask a-no, I mean they stand up. So they do to blow their precious noses, to hoist their slacks, or call out to an acquaintance afloat or ashore. To change places, up they get. For purposes of harrying peaceful cattle on the banks or startling horses 
turned out for well-deserved holiday, stand up they must; as if they were unable to yell and make other horrible noises while sitting down. Nearing a landing-stage-and nice things those are-they rise in a body. Body is the word I am always thinking of for these, trying their level best to convert themselves into demned, damp, moist, unpleasant bodies. I never can make out why they are not all drowned, or, if there was one sensible person aboard, knocked into the bottom of the skiff by means of the paddle-boathook applied to the top of their heads, just to show them the error of their ways.

These navigators must be awfully disappointing people to the local coroner. If he understands watermanship at all he must feel defrauded of many fees quite his due, for they do play with death most fearlessly or unthinkingly on the river. River! I saw some of them the other day going on in just the same way on the sea, till they landed, and then, to give their skiff a fair chance of reaching old age, they set to jumping over her. As to personal regard for the ship that carries you, I do not believe they know what it means to care for your craft pretty much in the same spirit as a "merciful man" cares for his horse, making it a friend rather than a mere conveyance or conveyer, and being concerned in its welfare.

It was on the road from Newhaven to Lewes, viâ Telscombe and Swanborough that at twilight of a dull December day I found a black kittenor, rather, it found me. Here we are in co. still, and are likely to be, for the critter shows no intention of quitting, and as it is a good bit better than me on a very public trial, I am not foolish 
enough to go against the book and take it on a second time. We met-not by any means in a crowd far from it-quite a mile on the Telscombe side of Newhaven, no one in sight and not a house for ever so far. Naturally I ventured to stroke the tiny mite; perhaps, naturally, too, she took dislike to my tyke, the mildest-mannered old poodle that ever got himself smothered in dirt directly he was put into company trim. Anyway, before you could say the initials of "Jack Robinson," his lordship, or her ladyship, was on the back of my neck, and there it, he, or she stopped for the next three hours or so. Perhaps it is a French cat, and said to itself, "J'y suis, j'y reste."

Be the nationality as it may, the motto was acted up to all right, and stuck to, the motto and me, the kitten doing the sticking like a Briton. Not an inch would it budge to oblige anybody, and I couldn't reach round to shift the plucky little beast, so must march "with a black cat on my shoulder" right through-or, rather, round, for I skirted it for fear of being chaffedthe City of Telscombe and all the way to Lewes Railway Station. Thereabouts we got on better terms through community of taste. After two years' trial I have declared on Horlick's malted milk tablets, and many a time get all the stay I want between breakfast and dinner out of a dozen or so. Not knowing how long the morsel of a pussy cat playing Old Man of the Sea to my Sindbad the Sailor might have gone without refreshments-it gave me a hint by chewing my ears-I tried to purchase a refresher on the road, but failed. In those parts small roadside landlords are apt to be what they themselves call 
independent, or others surly, and only trouble to open for you in Sunday's closing hours during the summer. So I tried Horlick on the dogwhich was a one-pound cat-and she ought to write the firm a testimonial. About a dozen tablets do me well for a lunch. My young friend wolfed eight-just gave 'em two or three licks for a start and then bolted them whole-in as many minutes, and asked for more. But, malted milk or no malted milk, she was like the gentleman rider who won a race at Plumpton a few years ago, and only smiled superior when adjured to get off to be weighed in. "Not till they call 'all right," " said the clever amateur. "You don't get me disqualified like that." As close as a limpet she stuck until I was safe in my stable. Right along she selected the back of a high chair, and has bossed the show ever since.

From Lewes to another training centre, which you could also do from Newhaven, is only a step, or at least not much more. This step I took many a time and oft while Gatland had the training quarters at Alfriston, on the Cuckmere River bank-the establishment christened Wingrove House by Charley Archer, after a very well-known and popular racing gentleman, and now in Batho's hands. The pace did not kill Gatland, a singularly careful man in all his habits. Poor, plucky chap that he was, he died of a painful, lingering disease, and lies in Alfriston's breezy, churchyard, only "moved from over the way," with the stables just on the other side of the Tye, a bit of common land, dividing his old house from the church. Finding Gatland's almost unmarked grave, I called to mind Lindsay Gordon's sick stock-rider, and did so the more 
easily because of something in the Australian line that happened to me at Litlington, about a mile off across the Cuckmere River as the crow flies. Gordon's words were :-

"Let me slumber in the hollow, where the wattle-blossoms wave,

With never stone or rail to fence my bed.

Should the sturdy station children pull the bush-flowers on my grave,

I may chance to hear them romping overhead."

Neither stone nor rail fences Gatland's bed on the grassy knoll under the grand ancient church's shade. Just a green coverlet and a little fence of evergreens does duty-nothing more formal. He may not, I hope, chance to hear the Alfriston children romping overhead. I hope not, for I am a little old-fashioned in such regard, but as he dozes and rests he may hear the youngsters, as they play on the Tye next door, and run down to the river bridge through the narrow passages, locally, "twittens"- he himself was the first to teach me the meaning of that Sussex word-or might catch the measured tread of the occupants of the stables that were his as Batho's string goes out making for the rise to the downs or, returning, paces through the narrow street to the yard. Besides, all the details of training stable home routine which the experienced ear can catalogue, each by its separate, distinct, incidental sounds are within easy range. 


\section{CHAPTER VI}

\section{PLUMPTON AND ITS COUNTRY}

INCREDIBLE as it may seem, nevertheless I do assure my readers one and all that very many of the (now old) boys who went to school at Eastbourne, Littlehampton, Worthing, Bognor, or Brighton, before that spread itself so much, never for a moment dreamt that anybody could put his foot or any other part of him on the Downs and say, "This bit is mine, so you must keep off it." Pretty nearly every condition favoured the belief that they were public property. You might go bird-nesting there without fear of interference, and so you might disport yourself butterfly-catching to your heart's content. No one ever checked you in that sort of hunting any more than they did those who pursued their game with packs, harriers, or fox-hounds. What is more, trainers -I am not speaking of the day before yesterday, you know-were given the run of gallops they wished to use, the owners and farmers of the land being quite pleased to have the gees exercised where they could see them, more especially since the stables made a market for hay and corn. Very little land was then broken up on these hills. (Speaking for myself, I wish a plough had never 
been seen on them, nor a turf moved to get the stones away, and, I may add, spoil the going.) Villages here and there, detached farms or solitary barns with walled yards for lambing, also sheep and shepherds and shepherds' dogs, were details about which most people, old and young, did not bother. They "occurred," but were not unpleasant nor worth objecting to. Goodwood, Brighton, and Lewes's race-stands might want some explaining away to keep the notion of freedom quite entire; but then, also after a fashion, they were evidences of the tract on which their racing was held being a playground open to all.

About the only obstacle you ordinarily found in miles of walking or riding would be a sheepfold, and that would not interfere with you much, because such were pitched in sheltered hollows, and anyone who knows how to get about downs is aware that the wise man never thinks of going into the bottoms if he can possibly make his way round on the tops. When some of us began to give the ranges a tone by our presence, their green spurs abutting on the towns were not of much value. One need not have lived many years to recollect when they began at the bottom of Elm Grove in Brighton and the Queen's Park Cricket Ground was an encroachment on their area. Thence the turf was unbroken from the town to Falmer on the one hand, and to Rottingdean and Newhaven on the other, and when rifleranges were proposed to be, and subsequently were, set up in the valley under White Hawk Hill, where the races are held, not a few locals were unpatriotic enough to grudge them to the volunteers just enrolled. Objection was based 
on the shooting's interfering with the assumed rights the public had to the downs.

As I said, the idea that these belonged to individuals, were theirs to give or sell or take away by enclosing, or make impracticable for pleasure purposes by converting pasture into arable, would have been scouted as quite absurd ; though occasionally one did hear of the Marquis of Bristol or the Marquis of Abergavenny or Lord Chichester at Stanmer, Admiral Shiffner of Offham, Lord Gage at Firle, the Gorings of Wiston, the Campions of Danny, the Beards of Rottingdean, Lord Leconfield and the Duke of Richmond out in West Sussex, and the like. The farthest one got then was to conclude that "perhaps they had something to do with it," in a vague sort of way-maybe as Lords of the Manor, or possibly as trustees for us who played about on them a-foot or a-horse.

I cannot bear to picture to myself what the hills might be like between Brighton and, say, Plumpton, if they were all brought into use as is the land in the farmer's near neighbourhood. As it is, after all the cutting and carving about of the fine old pastures, there are about a dozen nice long or short driving and walking or hacking ways of getting across from one to another if you count in lifts by the railway which are available. The wedge of land which lies between the Brighton and Lewes roads never was particularly interesting quite near Brighton-at least, not as down land. For instance, it was not until one got along on the Ditchling road to a square copse where the track from Withdean came in, that one seemed to get fairly into the open. Civilisation, as represented by walls and houses, even if the 
latter were few and far between, extended that far along the London road and past the Preston military barracks on the Lewes road till by the latter you got under the brow of the old Roman encampment known as Hollingbury Castle. So, though Brighton's feelers have radiated vastly of late and the area between them been covered with houses, the rider, driver, or walker making from the sea to the weald between Lewes and Clayton gets about as soon into the real country now as he did nearly fifty years ago. Then Hanover crescent on the east of the aforesaid wedge overlooked fields, and on the west or London road side, where Brighton ended half a mile south of the Viaduct, was a very extensive and highly-flavoured tract of allotment ground devoted chiefly to the cultivation of pigs, and named California out of compliment to that remote district, whose recently-discovered richness was nothing compared to that of Brighton's California piggeries. Then, as now, if you started for Plumpton by the London road you would not turn off till you got to Patcham, either (early) to go up on the Ladies' Mile to join the Ditchling road at Stanmer Park gates, by the side of which was good cantering and galloping, or, better still (delayed), branching away till farther on near Patcham Church, near to which an old bridlepath takes you, mainly on turf, right up to the north-west extremity of the Park close by Ditchling Borstal. You go down that, if you please, or along the face of the downs, and so by Westmeston or Plumpton Borstal to the cross roads.

Taking train from Brighton to Hassock's Gate and walking through Ditchling and Street, is pleasant in fine weather. (I call the station 
Hassock's Gate, and I mean to. What business has anyone to take the gate off? No more, I guess, than to cut away Burgess's hill or Hayward's heath, or Wivel's field.) I believe as nice an excursion as a moderate walker can want can be had, starting by rail to Falmer, then through Lord Chichester's Park, and over the downs straight across to Plumpton Borstal. A second, also by way of Falmer Station, can be mapped out, turning to the left past the Swan in the village; and a third, perhaps the pleasantest of all while it lasts, is to make the longer little railway journey on to Lewes, then pass the racestand (there are three distinct picturesque ways of walking between the White Hart and the racecourse), and on over by Black Cap and down through a long copse which brings you not far from Plumpton Crossways, on the very ancient road between Lewes and Bramber castles. Bythe-by, if, starting from Lewes, you stick to the metal and keep under the hills by Offham, afterwards leaving Cooksbridge on your right, you have rare going along one of the best roads in England, and pretty scenery on each hand all the way. I have not come to the end of my list yet, but, as I have a good deal more to say, let the remainder of the routes stand over, merely remarking that, thanks to fossicking about in the style indicated, I can always if I so desire do Plumpton pretty fully without going near the place. What do you think?

I never go near Plumpton without wishing that someone would put up a nice hotel there, and bring enough customers to make the spec. answer. A rare site this for a convalescents' resort, to which sound folk might come at will. 
You cannot find a better for poor bodies with inclination to weakness in the lungs. I wouldn't swop Plumpton for Ventnor if the patients concerned were only a little bit inclined to be weak, you know. But, then, as readers may perhaps be aware, I am very partial to the South Downs and the Sussex Weald country that lies near the northern feet of the great chalk ranges. None of the seasons would come amiss to me down that way, but for choice give me spring. When the days are drawing out strongly and the sun is asserting its power; the early butterflies need not fear getting nipped; the hedges are growing blind fast, and most of the big trees' leaves following their blooms out; when those who know where to seek for them may find small birds' eggs, and not only the voice of the turtle is heard in the land (when is it not ?), but the cuckoo has a word to say, and in quite different fashion from his June, July, and August speech ; then is the time for the lover of the country to take liberal doses of Plumpton. "Lord help 'em! How I pities those unhappy folk" who just run down to the meetings and bundle off at the earliest opportunity-that is to say, by the special train service which the South Coast Railway Company have made very good lately. I trust that while they are on the spot they do appreciate the solemn old grey-green downs that overlook the racecourse's slope, itself a strong rise, but paltrily insignificant by comparison with their towering steeps, the highest getting on for 900 feet above sea level. Also, we will hope that the outlook among the oak-timbered countryside may, perchance, be grateful and comforting during the restless division's brief visits. 
Let me tell you, my brothers who like Plumpton's pickles, you have no conception of what relishing sauce is to be had free, gratis, and for nothing right on the premises, or next door to them. Only half a mile from the cottage garden at the corner of the course, into which, as I wrote a few weeks ago, poor Sensier jumped and upset a hive or two of bees, is a marvellous bit of romantic river country in miniature. Our up-todate photographers could take bits of this and develop 'em in such style that you would believe you were looking on a mighty river hemmed in by gigantic rocks and rushing over stupendous falls. That is the way they bring out authors' houses in celebrities at home, lending to a mere dustbin an importance which almost makes you cease to wonder how the great Mr Backscratcher can get a study as big as the Royal Exchange into a forty-pound-a-year villarette. The thing is done, you know, because you see it in print as per photograph; and we all know that one must believe all said in newspapers, also that the (photographic) instrument cannot lie. For myself, I do not want any enlargements of Plumpton's purling brook, which even a $\mathrm{Mr}$ Cheviot Hill might pronounce beautiful without an artful, artless Scotch lassie to give him a lead. The soft-voiced chatterer's flow is good enough for me as it is, with its steep walls and pools worn out of the red sandstone, its ferns and flowers, overhanging bushes, and trees that quite hide the best part of its beauties from strangers. You might drive down the lane a score times in summer, with the water not half a dozen yards away, and not know that the brook was busily going on, unless you had to look for it. And the 
flowers! Where is there such choice? You have, in different parts of the place, clay soil and sandy soil, and on the higher ground chalk, and the vegetation appertaining to each, as also results in growth and colour tone consequent on blending the various plant foods. I declare that you get almost as many different kinds of flowering nettles here as you do varieties of other blooms of all sorts in less favoured localities. Primroses-despite the traffic in these for market, especially on Disraeli day-you may stand in one place and pick a basketful. Bluebells - the banks will be blue with them. Wild anemones-they make a pinky-white carpet, thick as Millais's fallen apple blossoms. Cowslips - if the Lincolnshire people came this way they would start a cowslip wine brewery as big as Bass's show, or getting on towards that in importance. Wild geraniums and orchids, dog violets, cuckoo flowers, lords and ladies in full orange-berry glory, and all the many blooming weeds with which we are so familiar, except in giving them a namethere they are so that you can mow them with a scythe.

Healthy? I believe you. I said it was just now, but will not write too much for fear that Mr Hodgkinson may do away with the racing in order to cover his acres with a gigantic sanatorium, and so over-populate the land that there will not be flowers enough to "go round." Just one word more, though, as to health. Come with me and be introduced to an old friend, quite a young chap in his way, who shall be a sample of a dweller in these parts. How old? Eighty last Christmas, and as sound as a bell. (You may prefer a bell of brass-why bell of brass, or, 
for that matter, bell, I never could make out, but as "a bell of brass" is the standard, we will bring that in.) A rosy apple-faced little man he is, with a delightful frock all over quiltings and smockings, and a pair of nimble little legs in leather gaiters, warranted by wear to stand any weather. You see that hill in front of you, a furlong and more high from foot to crest, with a road cutting up its face, quartering it in a way? Good! Now you may not see, but will believe me when I tell you that Ditchling Common lies some miles away from where we are, and is a great, roomy, open expanse. Well, the last time that I called on my young-old friend he was not at home, because he had gone off on foot to find and bring back single-handed some runaway cattle reported to have located themselves up there. Not bad for eighty, is it? And as to the Borstal-that is what Sussexers call the hill and its descending road (you see a Borstal stake in the Plumpton programme)-I would back mine ancient to make straight up the grass while most of us toiled by the road, and, when we were puffing and blowing, after winning to the top, find wind enough to tell us all about Plumpton Place, a fine manor house once, and its moat, and the reedy pond, and what the fox does if found in this part or that, and the company he has seen at Plumpton Crossways, meets of the hounds, and a lot more.

A very swell manor house this was once upon a time, as you would scarcely believe on looking at it now. I wonder the owner has let it go so wrong. The moat used to be noted for its bright, clear water, which shows that the Mascall, late Marescal, who first brought carp from the Danube 
and introduced them to England, did not know too much about their likings when he planted them here. He made Plumpton celebrated, too, by introducing pippins, of which the golden pippin is a great Sussex favourite now. Another owner of Plumpton was a Nicholas Carew, the family some of us recollect as holding Beddington and miles of land right away from that village up to Banstead and farther. A Carew it was who first imported an orange tree to England. The last we racing men know of the Carews was poor "Stunner," who, in Delight, owned the best threeyear-old of Lord Lyon's year. Mr Sutton would not have won that Derby if Delight had kept all right instead of breaking down-in the Chester Cup, was it not? Next door to Plumpton, at Street, were another family bearing a name racing folk knew well. This was only a matter of three or four hundred years ago, and the name is Dobell. One of that ilk was a persecuted Royalist, and escaped Cromwellian pursuers by riding his charger up a chimney into a secret chamber, where, of course, he would be safe. My old friend recollects "hearing tell of it," but does not commit himself to facts or dates; as also he is guarded about another temporarily local celebrity, Simon de Montfort, whose camp was up aloft on Plumpton Plain when he set forth to meet-and, as it turned out, beat and take-King Henry in the battle of Lewes. Guarded he is, but has seen relics of the fight discovered. 


\section{CHAPTER VII}

\section{LEWES AND ITS COUNTRY}

I FIRST knew this most ancient borough when Drewitt trained at Astley House, where Escott is now located in a vastly improved establishment. Then George Fordham, his son-in-law, had a house not so far off on the Brighton road. That was before Lord St Vincent had moved to the Telscombe quarters now held by $\mathrm{Mr}$ Gorham, and when William Goater was turning out big winner after big winner for Lord Westmorland. What a fine figure of a man his lordship was, and what scope Goater had at Findon, with practically all the downs within reach, east and west of the Worthing-London road at his command, and nothing to pay for going on to the ground!

If you want to find out all about this very characteristic county town, start by reading up at the excellent Fitz-Roy Free Library, where to my joy I discovered a collection of works of reference mostly dealing with Sussex, for which the town is indebted to $\mathrm{Mr}$ George Holman, thrice in succession Mayor of Lewes. I began to read myself up regarding the ancient town, which-so says a friend-Chaucer styled Louse. 
This find was very all right up to a certain point, as I went well with Maro Antony Lower, a real authority on the county and all its works, went strong indeed, and was as one should be at Rosherville, doing a Happy Day, till I came to his playing William Cobbett, who is made responsible for calling this the town of pretty girls and clean windows, in, as I think, his (Cobbett's) "Rural Rides." That led to my downfall. I like to verify my references (or, better still, get them verified for me). Accordingly, remembering where a collector of Cobbettiana had recently located himself in the place, I looked his establishment up, and we together looked up-or rather, after-the "Rural Rides" for hours and hours in a small cupboard sort of box-room and an atmosphere richly impregnated with that pungent, nose-tickling dust begotten of closely-packed old books. One of us had to hold the candle and the other cope in its dim light with books packed in piles which slid, books stacked in rows which toppled over on the least provocation, little books wedged under big weighty ones, and great tomes that cast themselves at you if you meddled in the least with their foundations.

We found Cobbett galore :- " Paper against Gold," "Advice to Young Men," "Advice to Young Women," "Cottage Gardener," "Cobbett's Sermons," "Legacy to Parsons," also, "Legacy to Labourers," each with a lovely dedication about I 80 deg. in the shade; "History of the Reformation" (a sweet book that), "Ann Cobbett's Cookery Book" (dear old Ann's cuisine wanted a cask of brandy and a two-quart jug of cream always on tap in the larder, if you were to follow her recipes), 
"Cobbett's English Grammar" (William's English grammar was irreproachable), his "French Grammar," "American Gardening," his "Life," and "Emigrant's Guide" ; in short or in long, all manner of Cobbett's works, a whole library of him, save and except the "Rural Rides." We at last retired defeated, disgraced, sneezing to disagreeableness, aching most woundily in our poor backs-myself no forrader than when I started.

Still, next day I got some compensation, for the downs were simply grand where I was, up on the Cliffe, the great island dump of downs styled by the authorities "a fault." If the Cliffe is a fault, I am grateful for the error made in forming the face of the country out of accord with what the scientific gents consider proper order. But for a certain amount of hogheadedness, I should not have done the Cliffe, for I thought I saw a motor-car up on the crest of the hill. There was something high up on the crest by the golf links, going along as one would think only a motor-car can. "This ends the downs for me," says I. "If such articles are to do the downs as well as the roads, all is up with me, for I have now no refuge from their noise and smell." To know the worst, I climbed and found no motor carriage, but-steam ploughing-machine tackle in full work dragging up granite blocks to build a Martyrs' Memorial! The "cars" that appeared to be climbing the face of one of the steepest combes in the county and careering along the ridges, were sleighs carrying big cubes of stone, dragged by steel ropes. The spectacle instructed me a lot in what may be done in warfare, and relieved my mind much regarding the future of one of our most precious English playgrounds. 
Up, up aloft there, pretty nearly all alone, with the steam-engine and the larks, the granite blocks and the last of the swallows, the lovely view and the black-faced sheep, I had time to rest and wonder how the late $\mathrm{Mr}$ William Cobbett came to set himself up as a judge of clean windows and pretty faces. Judging from what I know of the male married members of the family, he must have got some of this information at second-hand, and not by looking at the pretty faces. He surprised me at Lewes, did William, because he was, for his day, a very up-todate journalist, and I wonder at his missing a chance of lugging in gridirons instead of talking about pretty girls. He couldn't well have missed doing so if he had happened along when a Martyrs' Memorial was in course of erection. You see, they used to keep in stock at the Sussex county town gridirons for grilling martyrs (that is where the memorial comes in); but holders of the true faith, whichever it might be, were not particular about locality. The religious party boss for the time didn't mind where they burned, so long as they could get a supply of obdurates who would rather be killed than give in to con- or per-version. So far as I can make out, when the Old Faith section was in the chair they served up Protestants hot and hot; but the Protestants also had their innings now and then, and indicated a difference of opinion which did alter friendship by spatchcocking or pulling out of joint the opposition, just to show how Christians love one another.

Seeing how things went, I do marvel that old William missed playing martyrs' gridirons for all they were worth in order to gently lead up to his 
light-sparring publication "The Gridiron." $\mathrm{He}$ had already had a few words, you know, on the subject in his "History of the Reformation," and could have so easily worked up to his own "Gridiron" through natural steps afforded by Henry VIII. (how he loved the Bluff old BlueBeard! also the Virgin Queen with the vermilion hair and general tendency to very high colour), Sir Thomas Cromwell, and Lewes's Great Priory of St Pancras, which master and man broke up for building materials. William, William, you were a fine journalist for your times, and wrote jolly good English, also handbooks of quality and usefulness never surpassed, but you missed picking up cues when you failed to play gridiron. The identical gridiron on which between a dozen and a score of men and women were stood to be burnt alive in Lewes, is shown to this day; likewise, like Flora's back drawing-room in "Little Dorrit," there is the spot where the roastings came off, still at the top of School Hill, and still almost in front of the White Hartwhere doubtless fancy prices were paid for a good window to see the show; and where now the greatest of all the Lewes bonfires-every division of the town has one to itself-blazes annually in memory of the martyrs and defiance of the system which they did so pluckily defy. And if the true Lewesians seem rather over tenacious and vindictive in keeping up such unpleasant memories, be it remembered that the roastees were one and all Sussex folk, some from the town itself, and very likely related to many of those who saw them burn. Suppose your cousin or your sister-? I think you would hand down the record pretty vividly to your descend- 
ants: and remember it takes astonishingly few generations to reach back a trifle of three hundred and fifty years. The institution of bonfiring suits Lewes and vicinity, and is harmless enough, take it all round, if you do your "remembering" wisely and insist on not forgetting that the bearings of uncomplimentary sectarian remarks lie in their application to Sir Guido Fawkes's era. Those who call the tune pay the piper. The Bonfire Boys take possession of the borough in their-well, hundreds is too few, and thousands is perhaps too many. They to a great extent take over the functions of the police as well. There is very great method of order in the apparent disorder which they control : a grand raree show is organised for an enormous constituency who enjoy themselves, and what to the inexperienced appears terribly dangerous is proved to be very otherwise. Time was, says my friend Mr G. F. Verrall-chairman of a bench of magistrates, if you please, and an ardent Bonfirer-that a good deal of rioting was incidental to the performances. That was mainly because of police interference and unwise attempts at repression. This led to trouble, out of which undesirable outsiders made opportunity after the manner of their kind. But now the Boys are allowed to do pretty much as they like, and by consequence ensure order, also respect property on their own account.

The best proof that the organisers and conductors know what they are about and can be trusted-it is desirable to recollect this when you behold flaming barrels dragged full tilt down the steep pitch of School Hill-lies in the simple fact that the Cliffe bonfire has never yet burnt up the 
old houses which every year it must (apparently) almost touch. This means experience and care. My word! you should have heard the magisterial Mr Verrall, at the White Hart, expounding the unwritten law of the societies to a company of young gentlemen who suffered somewhat through inadvertently, maybe, interfering with arrangements. They came for the bread of sympathynot that bread is so efficacious in cases of black eye as beef-and were given the stone-a rather good thing a stone, laid on cold in the early stages of a mouse's development-of admonition. Theirs was the only instance I came across where a "collision" happened, and this didn't matter much one way or the other. The sportsman with the variegated peeper-a pretty sight he would have been next morning if the kind lady who prescribed arnica for him had applied that remedy; I tried that tincture once, and came out as chromatic as a bit of oxidised copper ore-he didn't mind, nor the brother visitor, who had a bare patch where the skin had been knocked off the bridge of his nose. They sensibly consoled themselves in that, like the celebrated Roman Matron, they too had not been idle, and-but I must cut Fifth of Novembering and get on.

Stay, I must just re-tell a true yarn about the first original Guy Fawkes day. I say true, because two old friends used most solemnly swear to the truth of this ghost story. One poor chap, a good sportsman, is dead and gone-Mr Fred Howcroft, who ran one or two comic opera companies. The other friend would, I know, corroborate me. Here is the story cut short. My informants used to live near Tilbury, in an old manor house, rendezvous for some of the Guy 
Fawkes conspirators, to which at least one repaired after the coup manqué at St Stephen's. They both declared that at midnight on every Fifth of November-and mind you, one lived for years in the house, and the other who rented it, went down on purpose to investigate-they distinctly heard as twelve struck, the clatter of a horse galloped into the stable yard, the ring of a horseman's heavy riding-boot heels as he hurriedly dismounted, and the jingle of his spurs on the cobble stones, then the stable door open, the footfalls of a horse being led into the stall, the banging of the door as it closed, and the tired tread of an armed man as he marched into the house. Do I believe a word of it? That is as may be, so far as regards the manifestations. But so far as the narrators' good faith and the trustworthiness of their evidence as the truth, the whole truth, and nothing but the truth, according to their personal observation, I always was quite satisfied.

But let us quit gunpowder-treasoning and turn on the country tap. What go we forth for to see down in Sussex? Summer. Not the summer season according to the calendar, which may be winter, autumn, or, still worse, spring; but jolly fine old-fashioned hot weather. Summer with Mr Sol blazing over your head and on your back, more power to him, all sorts of vegetation a-growing and a-blowing at express speed, and the farmers as crooked as two sticks in their tempers, being afraid of losing their grumbling form by reason of falling out of practice for ten minutes or so, since they had a fill of rain to grow the grass and now a baking sun for haymaking. Summer, the sort to make you cast 
back to the old days when as a boy you kicked all the clothes off at night and tumbled yourself into river, pool (or pond, for that matter), or sea by day, even if you had to play truant- "dolly," we used to call it-to let instinct have an innings. Summer, with the glaring, blazing, broiling sun to make you jump for thinking of boxing about in a sailing boat from Newhaven Harbour, as soon as a whiff of Stockholm tar gave you the office, or want to loot the fit-out of the innocent angling stranger-piscator and viator in onemaking up to the upper reaches of the Ouse on fishing intent. The Ouse? Oh! yes, there are Ouses and Ouses, and salmon in both-I mean in some-and Lewes has one, as I have mentioned before. How many do I know, not by sight, as you may say, but on speaking terms? There is the Yorkshire one, by whoselbanks have I trudged many and many a mile, a very presentable stream up by York, and a very muddy flow down by Selby, where the saffron grows, and the wild hop flourishes to an extent which Kent's cultivated branch of the family might well envy, and the dewberries are big as raspberries. Then there is the Bedfordshire member of the family, which helps Cambridge to train its crews and passes into the sea down King's Lynn way, a very muddy sort of flow. The French Oise, on whose banks I was last week, is, I suppose, to be reckoned a member of the class-and there are others.

The Ouse and the Cliffe-they come together along the Glynde road-seem perhaps Lewes's most special landmarks. The pleasant old Bear Inn achieves the feat of being literally in the one and the other. Let me explain that this is 
managed by what is sometimes called a double intender. One side of the inn merges into the bricked face of the river's channel by the bridge. (The bridge, if you please, there is no other for miles.) Thus the inn may be said to be actually in the stream. It is also in the Cliffe, which in Lewes means not only the great hill-face, but also the straight, shady, old street leading thereto, said street named on the lucus a non lucendo principle, seeing that it is about the lowest-lying and levellest street in the place. This low-lying Cliffe district distinguished itself once in the good old no-sanitation times by showing a clean bill when the rest of Lewes was terribly afflicted by one of the fashionable epidemics of the period-typhoid, I think. As it might have been reasonably supposed that the higher parts would have stood the better chance, this was puzzling. The reason lay, of course, in accidentally superior water supply. The Cliffe furnished itself from a spring descending fresh and sweet from its elevated namesake, subject to no fouling en route. Let me hasten to add that all the town's water has long been above reproach. Let me also explain to the Bear that I do not call him or it a hotel because it seems too oldfashionedly solid and snug; one does not somehow associate the more modern appellation with either quality. The good hostelry is roomy enough, as witness that spacious apartment, or rather pair of apartments, where the farmers used to have such fine market-dinners in the days of yore.

The Sussex Ouse holds big sea trout, and is a salmon river according to Cocker and the Fisheries Act. "Much improved," is the local 
verdict-and so I found it, strangely so. Never a dead dog or cat floating could I spot. Somebody must have bought them up and taken them home; they never decay on this river, and, once a dead dog or dead cat, always the same, is the motto they float up to. The isolation fever hospital mattresses, which, cast like bread on the waters, travelled in former years again and again to extreme points between Newhaven Harbour and Barcombe Mills, appeared to have finished their course of almost endless voyages. Nobody had doctored the town's drains with stuff to kill, or which did kill, eels by the million. No barge in evidence, to bung up the whole of the fairway. The swans, who look so pretty but are so ruinous to fishing, were, as usual on this river, quite docile and amenable; perhaps their being amiable is the reason why boys are permitted to steal their eggs. Wild flowers on the bank, from kingcups to ragged robins, were a treat, and homely familiar the tame animals, beginning with the mighty, lusty, black oxen and finishing with the little bright-eyed field mouse. On each hand looked down the great chalk ranges, good enough to rank as mountains to the ridiculous quadruped cited.

Let no man run down the Sussex Ouse, for it is-well, if you fancy that sort of stream, this would very likely be the sort you might fancy, not otherwise, because you may not care for a river with no convenient landing-place for eight miles on the tidal part, and no desire on anybody's part to make matters better. And talking of accommodation on the tidal stream, I wish someone would put before the South Coast directors the claim Newhaven has for consideration as a 
resort for yachting and boating folk. I hear that at least one of our leading yacht clubs is approaching the railway company on the subject of better accommodation for pleasure craft in the harbour, which has been exceedingly poor, if I can believe friends who have put into that port and regretted the experience. For sure, if their custom was cultivated-and only the will is needful to provide all desired-much use would be made of the harbour, an extremely handy one as regards its position for channel sailing. And when anything is being done I do hope that safe landing-places for those in small boats may be provided. At present there is not any at all fitting for the purpose, unless your craft is of the dinghy order; and at the only stairs which can be so called, risk of accident in embarking or disembarking is great, unless you have two or three hands to manage a boat of any length. Again, the town would benefit if the ferry at the Harbour Station were managed properly, so that visitors could easily cross from west to east, and vice versâ. According to local gossip, the existing ferry will shortly be reserved exclusively for the railway company's staff. In that case, visitors and others who go on the western side to look at the fort and the cliffs over against the jetty or mole, and are desirous of crossing to make towards Seaford, will be compelled to walk the best part of a mile to the bridge, and again as far back to the beach on the eastern coast, so realising the late $\mathrm{Mr}$ Richard Swiveller's unfortunate condition, being obliged to go a mile and a half to reach over the way. Now that the sea-wall from Ousemouth to Seaford is complete - and a very fine marine promenade afforded, 
adding greatly to local attractions-doing anything to put difficulties in the way of folks appreciating the improvements would be a pity. Surely the railway company, who are practically the Harbour Company, must be going against old public ferry rights in preventing or not furnishing means of free crossing. Still, with all its deficiencies, from the salmon-leap at Barcombe Mills to the British Channel, the Ouse has good qualities, as a naturalist can soon find out and a fisherman must. Its best is proximity to the downs; in genuine June weather, most lovely country on or off. What do I mean by "on or off"? Look you here. I may not ... be quite accurate in taking the Weald in with the Downs or the Downs in with the Weald, but for purposes of this argument I make them march together. Some foll-foolish to my mind, but I admit that personal taste may lead me away-do not care for the South Downs. I do, and could live on them all the year round, making up for bleak periods by the sweet balmy turns you have served out to you in due season. Moreover, I believe that a man might camp on them through a long life and never reach the limit of their infinite variety. Mind you, too, if he did pitch his tent up, up aloft, he is always within handy reach of marked change, for no farther off than next door down in the Weald-or, as in the West they would call it the vale - is different climate, different soil, different method of growth, of tree, herb, and plant, and between the two a border land of alluvial washing, Nature's neutral territory, where both the highlands and the plain give of their best. Let me have the upland for health and enjoyment, and when I am ill if anyone thinks I am going and is 
good enough to want to give me a chance, put me somewhere up on the South Down range.

Never mind about Switzerland or foreign health resorts ; do not listen to talk about bleakness and south-westerly gales: take me up on the ridges and find me a roof somehow. And in summer never mind about the roof, good Dr Downs taken a few hours per day will put you straight if anything or anybody can. Pine woods? I know plenty about pine woods, and like them much at home and abroad. Beautiful it is to be among the firs when the sun draws the "medicinal gum " aroma from their spines and bark, mostly from the fallen spines, as I believe, and the old cones, also the trunk's scales, crackle in the heat. Grand it is to be on the edge of a coppice with foliage of sorts distilling delicate scent, notably the tender leaves of the oak's second shoots, the hazel, and the briars. What more can the tired man need in an ordinary way than to look over a bridge or from a terrace on to tree-tops shot up from far down valleys with a ripple of running or falling water singing gentle accompaniment in time to their sway and rustle?

Not for a moment do I underrate the charms of fat meads and crystal streams where the lusty trout lie; the moorhens, built galleon fashion, perk along mincingly; the dabchicks worry themselves needlessly into diving out of sight; the water rats imagine vain things in danger; the swallows skim the surface; and the poor human can see many strange sights if so be he has only sense enough to keep quiet for a spell so that things get settled down, and he is regarded as a fixture like a pollard willow or an osier stump. Lanes? Did anybody ever hear me say a word 
against lanes? Why would I, when I count one of the Downs' chiefest charms their being footed by bands of ancient ways, paved, absolutely paved, with history and romance, old-time thoroughfares to be peopled at will by the imaginative daydreamer, dressed by actors in life's drama, making a procession a thousand years long for certain, as we know the history of England from the Conqueror's time, and marked, many of them by dwellers in our land before the Romans made roads not beaten up to date. Good-I say very good-are all the samples I quote and others to be cited, as, for instance, the coast. I have not brought in that yet, nor the river. Good old Father Thames! As he has cropped up, put him in the parcel with the rest, and then you can take the rest while I go for the Downs, more especially as they are in summer, and were when I made spells off to pay my respects to them this week.

Not all the scents of Araby can match the perfume of their turf. Araby? Araby, be blowed! Where does Arabia Felix, or any other-unhappy or otherwise-come in with a bouquet? They couldn't do anything for Lady Macbeth's little hands. She said so, and I shall never forget Mme. Ristori's making the statement. She was convincing, if you like. She and Mr Macbeth wouldn't have wanted any scents of Araby if they had exploited the South Downs before coveting their neighbour's crown, because, thanks to their corrective influence, they must have put all daggering out of the question, the mens sana being in corpore sano. Our Royal blend is of wild thyme and marjoram, burnet and meadowsweet, lady's-shoes-and-stockings and plantain, cock sorrel and sloe shoot, white clover and red 
clover, buttercups and the other yellow flower related to the sweet sultan, the last of the may, and some of the furze, also elder flowers and buckthorns, the daisies and the dog violets, the scented violets' leaves and the cowslips, the mosses and the grasses themselves making hay scent under your footfall, the kidney vetch, the milk worts and the stitchwort, the wild raspberry canes and the blackberry leaves-strongly aromatic both-and the hundred-hundred is it, or thousand? - other inhabitants of Downland. Our blend and want of music in the soul, which induces acting up to the deficit with a tendency to stratagems and spoils as well, could not go together.

I have often wondered why someone does not start a sanatorium on the Downs. What price that, with poor run-down mortals resting their eyes doing nothing but watching the rooks manœuvring and the jackdaws trying to go one better, the rabbits slyly playing, and the thrushes seeking a living far from cover, the plovers complaining, as is their wont, a stray seagull seeking what it may devour, the chats a-chatting, and the larks never at a loss for a voluntary till a discordant element presents itself in the person of a hawk, the doves - not wood pigeons, doves-busy in the hollows, where the mixed clover hay crops are so heavy this year, and the wagtails, ever fidgeting, the wheat-ears, who may not be caught as they used, and are now in consequence scarcer than before protection came, and the waves-not waves, but seas of clouds, shadows running over the shoulders of the hills and into the bosoms of the dells.

Who was it? Old "Ingoldsby," was it not, 
who wrote "As I lay a-thynkynge, and heard a merrie Birde as she sat upon the spraye." He did, and finished with "Here is rest!" He dwelt hard by some pretty Downs, Barham way, as you rise from Bridge on the Dover road from Canterbury. I wish the reverend gentleman might have given our Sussex Downs a turn before he came to the "as I lay a-thynkynge" stage. I would have liked to read his views on the views from them, which-but here I am a'most at the end of my tether, and not half got into my stride up aloft with the white clouds showing the clear blue sky, more and more illimitable in its depths, a grey haze hanging over the coast line, the brook-lands and weald spread out right away to Eastbourne and Pevensey like a map; over the way, three great chalk ranges, with on the sky line farther off the ridges cutting from Crowborough and up that way to East Grinstead, and right on to Reigate, pretty well. One, two, three, four, five, six beacon bonfires I can count, built, or being built, like conical huts to hold a hundred people at a time, and against some of these another wagon-load of furze or faggot-wood or brush stands outlined waiting to be unloaded. Down and over the hill's face I can see the patient bullocks deliberately drawing the plough; smart lambs - children of silly sheep-are taking advantage of the golf club's bunkers to make the most of the breeze, and doubtless passing votes of thanks for the kindly consideration shown in throwing up these nice little hillocks. Not a soul is within half a mile range, and enjoyment would be as nearly as possible perfect if one might lie on the turf, rest and be thankful.-But, good friends, don't you try lying, for our friends about here won't 
take a halfpenny worth of trouble to prevent the Downs from becoming one vast thistle farm, and if you do sit down you will know torture, as do the poor dogs, who, like King Agag, come delicately. If you feel that way inclined, play at having your foot on your native down and your name being anything you please to call yourself. But don't put anything else that belongs to you on to your native or otherwise territory, unless you fancy being an animated pin-cushion.

In a fine September week, when tied down to go racing instead of wandering at Lewes, a cutting from Mr Lucas's "Sussex Highways and Byways" came my way. The writer of the Sussex book put before strangers-i.e., readers not personally acquainted with a recently deceased Sussex worthy-a word portrait so skilful that these ought to be able to make for themselves a presentment of the old sportsman, a picture very near to the good fellow in his habit as he lived. For myself, had I happened promiscuously on the sketch without a word of reference to the original's name or locale, I should, as must almost everyone personally acquainted with the $\mathrm{Mr}$ Horne in question, have confidently identified my old friend. At his feet I have sat many a time and oft, absorbing sport and love of country life, and wanting with eager longing to be free to go and do likewise, as he descanted on wanderings far and near in the country where, getting on for almost three parts of a century, he was a notable character. Once upon a time John Horne had been a well-to-do sportsman, and a sort of halo from his better-off, fast-going days hung round him ever afterwards. Quaker-bred he was, and a quaker connected with many rich 
families of that faith-do you call it a faith? Whatever it is, I can say, as mixing many years with Quakers, it turns out real good sorts when you know them, and I knew many. One great financial magnate used to learn to play the concertina in fear and trembling in one of our top-storey bedrooms; and a son of his, though wild and a runner-away to sea, declined to cut the connection. Also he declined to give up chewing tobacco while nautically home for the holidays, and carried that habit and great dismay into the meeting-house, where he was an assiduous attendant, frequently moved to let off strange words. Quakers by the score I have had to thank for many pleasant days, so I hope you will excuse my excursing a little on their account.

A great "character" was John Horne (in his county "character" means little more than a person of strong hobby, who treats conventionality lightly; it carries no disrespect), and he was widely known. I am not surprised therefore that Refereaders who recollected the kindly old man, some earlier than I, should write me regarding him and his ways, particularly his partiality for sticks, the cutting them and seasoning. Now, when I find anybody interested in this line of collecting I often want to foregather with him or them and discuss the ethics of the stick business-mostly illegal, viewed strictly. Acts such as taking short cuts where you do no damage to crops or disturb game, or cutting a promising brier or thorn walking-stick of high value in your eyes, though not at all likely to be turned to account by its proprietor except for stopping a gap in a hedge, are unlawful, I believe. 
At the same time, if you, the trespasser or depredator, don't mean any harm, well, where is itthe harm, I mean-seeing that you are in your own estimation honest as Izaak Walton's fishers? Feeling on a safe platform of morality, I would still like, as I say, to talk over the rights of the case, because it is hard to read of old and poor people being sent to prison for pulling a few dead sticks to boil the kettle, while you, well-found, deliberately help yourself to live wood which does not belong to you. John Horne would no more dream of taking what wasn't his'n than of hurting a child, if he considered the something conveyed really belonged to anyone; but when you come to think it out, a pretty taste in the walking-stick line might easily get you locked up with an awkward difficulty before you in the matter of getting out again. At our last interview I asked him if he still had natural sticks all over Sussex? Yes, he had; and forthwith he wanted to give me a holly sapling with a natural knob, one that had been in a midden for months, he said, and up a chimney for a year. Wherever he went he would mark out a stick, and in due time cut and season it, usually with the future possessor to whom it was to be presented already fixed in his eye. At all manner of out-of-the-way houses had he saplings of one sort and another stored. How a man who loved the things as he did, like a real connoisseur with a curio, managed to bring himself to part with them I could scarcely make out, except in one regard, and that is the point I particularly want to put before brother walkers.

The veteran was of my old-time friends, the warmest apostle of walking as a pleasure, exercise, and health-maker, and in seeking to make a con- 
vert of a youngster he would bring a stick into play. In my day, you know, a straight, wellseasoned ash-plant was well worth half a guinea. You scarcely find one genuine naturally grown ash-plant in a thousand-nay, ten thousandnow because they are grown in moulds "to order" by the thousand, so that soft, quicklyshot-up seedlings are to be had for a few pence. Ash-plants they are by the dictionary, but not in the same street with the old sort that grew themselves. No one knew the value of a specimen better than John Horne; but if only he could persuade a novice to take to his style of walking with a stick he would incontinently present a fine sample. How many trudgers have ever tried his specific method? Scarcely any have heard of it, I believe. Here it is: he used to declare that to properly balance the body in walking and "draw out your stride" you should hold a stick or umbrella poised on your finger-tips at about half-arm range. Instead of swinging your arms you were to sway them from side to side, and after practising any time this way you will find it difficult to do as well without the expedient as while being "led in your work" by the stick. I can strongly recommend the plan for at least a change on long journeys, especially for walkers whose hands are inclined to swell. But of course as it may mean holding your arms in a set position for a long while, practice is needed to guard against cramp and tiredness; when you are used to the method, you find it very helpful.

$\mathrm{Mr}$ Horne was understood to have run through his money owing to a love of sport not altogether going on all fours with strict attention 
to business. The business John Horne took up turned him into a sort of very uncommercial commercial traveller, calling all over the country where a farmhouse might be, and he took it as a sort of unconsidered supplement to one unbroken round of holiday-making in the open. He loved walking for walking's sake, and covered in the aggregate enormous distances per annum. Moreover, he loved best, loving most all things, both great and small, being a sportsman who held a gun straight, and could take fish cunningly; a fine rider, boxer, and runner; but kind, always soft-hearted. No one knew more of birds and beasties' haunts and runs, nests and lairs. Who could, since he was always about with both eyes open, eyes that knew where to look as he trudged, and a most dependable memory? Last autumn I ran against the old gentleman, still upright as a (straight) dart and the "moral" of Jorrocks's James Pigg in figure and get-up, only a Tom Pinch in feature and expression. "Eighty in some months I am," said he, "and never shot better at rabbits than I did this week."

Quite thankful I was to have Lucas on Horne, as it happened to be while I was fermenting over that unpleasant side of sport which makes me tired. Invaluable for disinfecting antiseptic purposes is keeping a book like the "Sussex Highways and Byways" by you-also to recuperate, clearing the cobwebs away, using it for guide to take many a joint run with its writer. To tell the whole truth, as I chanced to be in view of my old crony's favourite country I half made up my mind to cut work and let it slide while I took a spell off, following some of his routes over the Downs or in the Weald, where once he was 
qualified to make a census of man, woman, child, man-servant and maid-servant, with a shrewd guess at the strangers within the gates, the oxen and other stock, and a certain knowledge of all regular carriers' and callers' " days," fairs, markets, and cross-roads, where lifts might be reckoned on with certainty. For two pins, or one, or none at all, only a congenial soul putting me up to playing truant, I would have forsaken Lewes racing summarily and "offed" it somewhere, say to the sheep fair towards the Falmer-road, where immemorial shepherds and prehistoric dogs congregate, and wealthy dealers and farmers haggle for dear life over twopence-halfpenny on a five hundred pounds turnover. The air was all against walking, in that it made you want to run, and, so to speak, throw rheumatism and stiff knees, twinges in the easterly breeze, and shortness of puff to the metaphorical dogs, and start away at a good round, sound trot.

Whichever way you went you could not be wrong in poor old Horne's country, its uplands free, and the low cut up into all manner of patterns by frequent footpaths, occupation roads, quite public lanes, and parish or council roads. Within easy range you might pick half a dozen distinct tracts of country, strongly individual in character - neighbours, but distinct in type as are families of humans, from the great grey-green chalk ranges through the zone where the chalk and the clay meet, with changed vegetation to match the blend, the oak begins to grow sturdily, and the water to gather readily. Farther out crop up sandy Surrey-and-Birket-Foster heath and fir belts, with wide, windy commons, made for squatters and geese and donkeys, with white 
windmills, half of them cashiered by foreign importations, making landmarks like lighthouses or seafarers' beacons, and storm-tried and twisted firs. Again at your service are harder sandstone -ferruginous, often quarters good to grow anything, and leading up in series to high elevated, heather-clad hills, wild and poor as many a Yorkshire wold or Scotch moor, and for all we know rich in minerals; certainly holding plenty of iron. Through the brook-lands, where the Ouse was once a vast lagoon to Newhaven, the sea peeps up between Newhaven's head and the white Scars of Seaford. Villages by the dozen, mostly no bigger than a hundred years ago; hamlets by the gross, certainly smaller; parks and manor houses; old and new churches, flint and tile churches, brick and ragstone, and churches buried in ivy. Churches with shingle spires, churches thatched and walled with limestone blocks, tall stone ones, all sorts and sizes, except great, but mostly too many for the existing population-not to say congregation-dot the wide area. Many enough to half excuse the poor old devil who always gets cheated in trying to dig a canal to let the sea through and drown out the garrisons of these forts and picket-houses.

All the country-side was calling in familiar voices as I expect it called old John Horne when he made up his mind that the sensible man's conventional wants are few and the luxury of free elbow-room, fresh air, and exercise necessities. Tempted I was to cut work and do myself a power of good ranging as chance or fancy directed. Instead of which I "minded my book" and made believe to be content with a trifling turn next day round Lewes's big chalk detached lump of down 
called the Cliffe, in the grey filmy dawn almost stern and quite romantic, with the hill-tops only half revealed and the mist veils slowly clearing to presently leave the blue sky you get scarcely anywhere-except about the downs, and at that with an east wind. Fresh and clear soon came the views, as if smoke manufactured by gas, and lime, and cement, and electric light works were unknown industries, and nothing more dingy than a wood camp fire's blue wreaths soiled the turf whose every seed spike held gossamer webbing with dew-crystalled thistle-down caught by the thousand to the square rod. A trifling turn did I call it ungratefully? Perhaps I did; but not really unmindful of a great enjoyment available to any dweller in or visitor to Lewes with an hour to spare and power to appreciate these country charms what time brisk air made one wonder how poor folk, however rich in money or material money's worth, managed to live in towns or on low level anywhere. Available was the word, but availed of! no, as has happened so often within my experience as to make me consider dyspepsia among folk neglectful of their great opportunities to absorb perfect health a wilful criminal offence, and distaste for brisk exercise punishable without the option of a fine. 


\section{CHAPTER VIII}

SUSSEX ROAD-LORE

Would organising a milestone maintenance and restoration fund be possible? Often I have alluded to their being removed, maimed, or destroyed, wantonly or of set design. Nowhere do I find the work of restoration, or even substituting poorer apologies for the old indicators. Still, one may as well keep on appealing, as perhaps sooner or later we may wake up the somebody whose business it is to see after such matters and who makes a business of not doing so. Foundation of complaint is apparent pretty much all over the country, in some parts more than others, but nowhere is the inquiring traveller who wants to know, you know, worse off than about Brighton and those parts. On-or, rather off-the Shoreham road the milestones have pretty well gone altogether. The going of one noted landmark-" the six-mile stone," as it was generally spoken of, opposite a small pub. at New Shoreham, the Royal George, if I recollect rightmarks a quite serious local loss. What for should anybody move it away, I want to know. Again, the little bits of wood which did duty between Brighton and Lewes, and along towards East- 
bourne, are going or gone. Letting them fall to decay is paltry meanness, and stealing them is low work, something in the canary-birds' sugarlifting or blind man's dog's pannikin-buzzing line, quite at the bottom of the pettiest larceny.

As a matter of fact, the Lewes Corporation did walk off with one or two of the old mile-posts to use for their own purposes. That, perhaps, may be a reason why the eighth from Brighton on their road is not a post at all but a stone slab set up out of their reach in a first-floor wall nearly opposite Keere-street, a slope whose steep way is paved with the stony-heartedest of flint boulders. They can't get at that, I am pleased to say, or likely enough they would, for familiarity has bred indifference to the lessons offered by two gaols giving the town a tone. On the old London-toBrighton turnpike which runs through Lewes and Uckfield, are (where they have been left) very prettily adorned iron milestones with a device of bells, wild lily-bells, somewhat similar to the oldfashioned bell, which was a cup used for drinking, as also for racing prizes. Witness the Paisley silver bells. Going from one Brighton-throughLewes-to-London road to another-that running by way of the Chaileys and Sheffield Park, and so on by East Grinstead-you find the same character of lily-bells adopted for the Chailey Five Bells Inn. Now, what is the true inwardness and significance of the device? When I take my walks abroad on those highways I ask, but no one has reasonable explanation to offernot even the hostelry landlord.

Recurring to the subject of missing milestones and the Lewes-to-Uckfield road, I feel pretty certain as to what has become of some of these 
bell-ornamented distance-markers. Simply, they have buried themselves in the earth by their own weight. I found one the other day nearly sunk, little more than the numerals 48 at the top of the casting remained above ground-that and just one bell. An almost if not quite, identical device occurs in the graveyards near about. Mr F. Chatterton, writing from Sussex to kindly enlighten me, ought to know when he says that of the bells of which I spoke, with a true-lover's knot sort of scroll bow at the top symbolise Bow Bells-a suggestion another good friend made previously. Here is the letter :-

"Apparently you did not notice the very evident bow above the bells. The assumption that because there are bells on some of the tombstones they must have the same explanation as those on the milestones, is entirely your own. People living in the district have always been aware that on the milestones it signified miles so-and-so from Bow Bells. Whether from Bow Church or the parish, is not clear; probably from Bow Church."

But even now I am not certain that we have the right solution of a puzzle I, at one time and another, took a goodish deal of trouble to unravel. When my informant says that people living in the district have always been aware that the numerals indicate distance in miles from Bow Bells, the church, or parish, he quotes authorities never available in my little investigations. Not once but many times have I consulted people living in the district-Brighton, through Lewes to East Grinstead by two roads, makes my district for purposes of this argument-also asked Sussex archæological celebrities, and gone empty away. 
Really, for myself and quite a number of friends struck by the charming bells' device, I should be only too pleased to arrive at the true inwardness of the decoration; also to be told what roads to London, from north, south, east, or west, counted from Bow Church. "Paterson's Roads" does not appear to afford the required data, and I was almost discouraged from further search because my good friend Henry Hewitt Griffin-most alarmingly patient, persevering prober into statistics and all sorts of musty records happened to write about a book he thought of making out of tracking, like $\mathrm{Mr}$ Pickwick and the Hampstead Ponds, the London roads to their very source or first recognisable existence. $\mathrm{Mr}$ G., in sketching his plan, mentioned the extraordinray number of different points of departure or termination these highways radiating from the metropolis had, so that when you made any place so far from or to London by the stones, real understanding of the exact distance could be arrived at only if the particular point in London's City_or Southwark's Borough-was understood. If the Brighton viâ Lewes to London roads were measured to Cheapside, then possibly my correspondents are correct; but I cannot help fancying there is more local character in the bells on the Sussex milestones and the Sussex gravestones and finials of ancient Sussex houses than comes from connection with routes to Bow. I hope that recent correspondents will excuse my challenging their assumption that I did not notice the very evident bow above the bells. That is just what I did, on the milestones and the tombstones as well, and the coincidence struck me as precluding the explanation now 
so kindly volunteered, because the graveyard memorials appeared the older. My road-book makes the stones date from London Bridge and makes no mention of Cheapside at all, while one of the recorders itself states a distance from Westminster and the Standard in Cornhill. I do not call to mind Bow Church coming in in this connection.

The Commons and Footpaths Preservation Society is quite willing to go as low as milestones. I have a letter from $\mathrm{Mr}$ Lawrence W. Chubb, the society's secretary, explaining this, and also explaining but too clearly the reasons why they disappear. Unfortunately the state of affairs he indicates, with milestones on the inner side of hedges, or made off with altogether, in process of removing neighbours' landmarks, can be noted all too frequently. The way in which small or large grassy selvedges between the actual highways' edges and the adjacent proprietors' legal limits are absorbed is almost wonderful. Many of us are old enough to remember how forest land got itself enclosed wholesale, brought into cultivation, and then chained up to a title somehow manufactured in face of apparent barefaced robbery. A great deal of this assimilation has been stopped, yet much is engineered still from more or less common lands, and quite a lively industry regularly carried on by swell land-grabbers in picking up odds and ends anywhere from roadsides, etc.

The iron markers on certain Sussex roads were without doubt turned out from the county's own works. The very first of these smelteries for native-i.e., local-iron was installed just on the Crowborough side of the pretty park at 
Uckfield, formerly a residence of the Lords Liverpool, and I should say-this being so handy-their actual iron milestones were cast hard by Uckfield, handy to Buxted probably. Sussex iron was, you know, about the best in England, as it ought to be, because it was smelted with charcoal, a circumstance this last to make the district lament loss of any quantity of timber from the semi-common forests. Proprietors were not going to cut their own fuel or buy in the regular way when they might collar it at first hand or be cheap receivers to inferiorgrade thieves. Very dreadful such depredations were and are ; but, after all, sneaking other folks' wood is not so bad as laying felonious hands on the land where the timber grows, and keeping the lot, stock, lock, and barrel.

Miles rather than acres of Sussex forests went in the not long ago, and I can see plenty more being put in trim to be swallowed up. A nice ingenious dodge to this end is in vogue, and easy as anything if worked skilfully. All you have to do is to encourage gorse to grow right on the edges of the lands over which are certain rights for copyholders, etc. Its growth is carefully tended and directed till at last what were odd bushes scattered about irregularly take formal order, and presently constitute a remarkably compact, complete, well-trimmed hedge, to be judiciously strengthened by and by with posts and wire, and there you are, with the job done. I could show you hundreds to thousands of acres being so transmogrified from common to freehold, and so I could whole parishes dominated by a big proprietor who pushes his hedges out so as to mop up all the strips of green lining the high- 
ways. Little folk do not dare protest, big ones stand waiting their turn for a bit of swag. Mr Chubb's society fights, or puts others in the way of so doing, when warfare is practicable. But, strive all one can to check the abuse, grabbing never ceases, and expense beats protestants against the systematic land-lifters. Most interesting work is to be found in tracing out the course of ancient green lanes and piecing them together as best you may, filling in stretches where between recognised remnants instalments have disappeared. More interesting would be looking into the titles of land across or along which these lanes formerly took their course. You and I, Refereaders, may not be exactly in position to grumble at the species of land-grabbing, because if we had been about while the lanes were in existence and fit for circulation, our share of them would go no farther than privilege to use them for passage. Now, in the majority of cases-not by any means always - a good hard road has superseded the indifferent unmade way. But, all the same, that someone did collar the land itself is a sure thing.

Thinking on the days when the Weald of Sussex rang with the clang of the local ironfoundry's hammerers- "strikers" are they not called?-suggested comparisons on a time. (Pray, readers of the North Countrie also the Midland, pardon my lugging in a good John Wesleyism presently.)

I was making survey of the charming Sussex, so-called Wealden, scenery up Uckfield way, on the borders of Ashdown Forest, overlying undoubtedly rich iron deposits, also the Kentish coalfields that (maybe) are to be. So much I 
did, as I always can, to my intense satisfaction. Next I was dumped in Lancashire with skies made murky by stalks' smoke and grimy spoil banks; big wheels like revolving gallows, and cables coming out of the pits' depths; smutty canals and inky water gathered on the barren wastes' undermined faces; doleful, disused, dingy brickworks' buildings and forsaken cottages, looking all the dirtier for having been whitened; and, worst of all, deserted shafts, shuddery spectacles to the inexperienced in colliery ways and practices. Money, much money, more money, most money, might be in it-very likely was. Land paid, we will allow, far better from its subterranean crop than pastorally or agriculturally treated. What was dreadfully dull and depressing to one used to clean country, clear skies, and green trees and fields was no doubt just homely to those bred and born to the conditions. The pitmen's gritty life must be healthy, otherwise they could not be so spry and smart out of their coal dust, and their labour is well paid for-well, look at their spending-money. Nobody wanted pitying, and possibly all had happened for the best all round. Yet there was I mentally addressing the Sussex iron and Kent coal lands with the Wesleyism, "There, but for grace, go Kent and Sussex."

Did Sussex iron-smelting carry with it blackness for the country? Not much, I expect, judging from the prospects round and about the site of the first foundry in the county, overlooked by Hog House, decorated with a pig in iron, the Hogges' family rebus moulded at the works just over the way, scene of operations for "Ralph Hogge and his man John, who atte Buxtede cast 
ye first can-non for Henry the Eight times," as he would be called in the ring and in the year I 543. One local foundry hereabouts turned out for the Earl of Cumberland forty-two cast cannons of $6000 \mathrm{lb}$. each; but no trace is left except, perhaps, in an openness of country suggestive of forest-clearing for fuel. Here you are on a Kenty sort of hop-growing land, with mighty rocks occasionally and irony sandstone to be had all over the place for the getting out, to build houses or make walls for ferns to grow on. Away on the high ridges, fir clumps and bare lands-not really bare, you know, for heather, bracken, gorse, broom, stunted thorns, and heath flowers grow-do remind you of Staffordshire Hednesford's bleakness; but on three other sides you have farm fields and meadows richly wooded. Then at the back of you is Buxted Park, adorned with mighty oaks and thick pine woods, a branch Ouse to water the low meads and the old, shortcropped turf, telling of deer-pasturing. Deer there are, too, in plenty, and other game, woodpigeons in clouds wheeling again and again over the tall tree-tops before going really to roost, after making-believe to settle down for the night times out of number, and taking twice as long as the rooks to tuck themselves up.

The sky is clear and glowing - at least, was on the day in early December to which I referthe wind keen and clean; for all suggestion of shafts upwards or downwards, or racket of machinery, or din of works, such might not be and never have been. The halls' red brick might have endured all its days in Holland, where the new house set up yesterday and the centuries-old cathedral hard by are alike to a shade in colour. 
Age does the church in the Park-once hemmed in, so says local authority, by cottages, now nonapparent-show, but a rustic, green, well-cared-for old age it is. Rest and peace you are offered all about the domain, though you are forbidden to go off the paths or roads, and you may not bring bicycles or perambulators, neither may you wander, picnic, nor saunter? Cruel is that last, or would be, if Lord Liverpool's descendant enforced the notice-board order. If ever a place was designed for sauntering Buxted Park is, more especially for a meditative man taking his recreation wondering whether the spirit of quiet was ever driven away by Messrs Ralph Hogge and Co., smelters, gun-casters, and all the rest, but returned, and whether if works are to take their spell in due course Buxted Park is to be like the northern ones I can quote-oases, green spots in a desert of noise and fire and blackness.

Both Sussex and Kent may be fortunate or unfortunate as one pleases to value circumstances enough to become most prosperously black some day; after my time, I hope, if postponement will not hurt anyone. Sussex seems less likely of the two to be converted (and, I may add, that working its iron from the days of the Romans down to 1825 has left it clean enough all the same), but the neighbours' native prettiness is against their chances of being left as they are, for fate has ordained that beauty should in so many cases carry the fatal concomitant of coal or iron bearing. I know which aspect I like best. 


\section{CHAPTER IX}

\section{RYE AND EASTBOURNE}

That old-world outpost on the marsh, the Cinque Port of Rye, is a place I wouldn't willingly have missed doing, and would always take some trouble to renew the experience, if only because I like to be right in understanding; and a travelled stranger, viewing the town and the great hummock its site, must evolve a wrong environment for the grey stone and red brick turtle-backed settlement. You are impressed with its Low Country stamp, and in your mind's eye plan it out to fit in with Flemish towns and pictures. Suppose, my friend, you who have seen men and cities, you were shown in the distance a thickly-built-over island mound, set on a dead level of flats, dyke or ditch-drained, with on one quarter of the horizon sea rising from the shore-line. Would you not expect this city or burgh to be invested by moats, and poplars and willows, and quinces, with stagnant, none-too-wholesome-smelling waters, and walks or promenades mortifying gritty to the foot tread, as is invariably the case on water-side all the world over? You will, my friend, I guess, while first viewing Rye, the colony in question, be so 
impressed by a feeling of knowing it alreadysomewhere abroad. Accordingly you set to work to explain away the absence of copperasy green sheen from the tall buildings' roofs by light's effect, and take as heard a cheerful carillonade, a practically incessant discourse from the church belfries on the hill. A market-place must be, you know, nearabouts to the high-standing church or churches, and ponderous dogs patiently waiting their masters and mistresses' orders to tug big loads over very cobbly cobbled stones, or rattle off "light" save for two or three hundredweight of passengers. Probably hard by is a barracks and small soldiers doing a power of nothing with military but dilatory precision. The embarrassingly polite inhabitants you can't see, for the houses in between, make you pity a Royalty who must acknowledge salutes each moment. Nippers invisible to the naked eye ungifted with extra double microscopes are, you dare swear, responsible for much of the mild din, the noise-dust raised by life's friction within the township's walls, an olla podrida of sounds floating over the flats like a busy coast city's roar to the shipping far out at sea. Under the hillock's shadow are lusthausen to which, mere toy locations just over the canals from the burgh, citizens resort, cutting themselves off in imagination from town ways and responsibilities. The elders in and out of the settlement are deliberate, the youngsters nimble of foot and brisk of speech, fast in their games, childishly good-natured, and sweetly, sociably unselfish. You have seen the place, or something own brother to it, by the score in the Low Countries-the real thing. "Set" with the sheep on the flats, now in evidence, more cows, 
bigger dykes, and a shower of windmills scattered about the whole mise-en-scène-its own brothers have appeared to you time and again on canvas coloured by Nicholas and the other (Gaspard) Poussin, Berghem, and by plenty more who drew what they saw in Flanders and Holland. I put it to you, Refereaders, whether if you didn't know who Rye was, so to speak, and took it on in casual rencontre without Winchelsea to give you hints, you would not write down this Cinque Port as Dutch. You must, I am sure of that, and so, as I said, I felt satisfaction in proving the place for myself.

Dutch, not a bit of it; but very English, though English of a peculiar type, is old Rye, what is left of it, and New, what has been added of late, mostly with reverential desire to preserve the unities and assume medirevality if you have it not. A quaint mosaic in many anomalous ways, an "amphibious" resort where the agricultural and sea-going industries meet and merge, is this most peaceful haven of rest, eloquent always of stormy, strifeful days, yet a nook wherein to take breathing time, thinking of made rather than making history. Rye offers a calm land anchorage wherein to lay up for repairs ; or as paid off, in permanence to dwell and be thankful, putting aside tiresome harness of life's hard Sturm und Drang. Here, if anywhere, you should "forget" as one forgets long toil in the transient sleep that might be a night's or of a few seconds only, but means an absolute break of some sort in labour's continuity and refreshment withal beyond the power of all stimulant, cordial or medicinal. "That solar shadow as it measures time it life resembles, too," says the 
sun-dial facing the wonderful old clock in Rye's church tower. A busy man couldn't absorb this text and sermon in one, taking it well into his system, nor an easy-going one either, unless in such environment as the setting, where it came to me at the back of the market hall. (Under the hall is stored a century-and-a-half-old fire engine bearing the name of Brahma, relation of the lock-maker, I suppose.) An inoffensive, appropriate method of mensuration, too, is the dial's; no noise, no wheels to go round and click, no whirrings at recurrent crises, marking more or less important sub-divisions of time which means life, no strikings and chimings, no windings up, no labour, manual or mechanical-simply automatic record of slipping, solving lapse with the total loss or gain - who shall say which?-wiped out at sundown and no score carried forward.

Worth a bit to a hard-driven worker, you know, is a spell of sitting under the sun on a day in late August while he preaches to you from a text like that. I wonder whether good old Ingoldsby used to come over from Barham way - (Tapperton Grange, was ii, he called Barham? I think I saw the pretty old house advertised in Rye for sale by auction) - and had been resting under the dial opposite the great church clock when he wrote "As I lay a-thynkynge." Perhaps he had, for he must have been fond of Rye and Winchelsea, and his fifth quarter of the world, Romney Marsh, that in his days had not so grown out of the sea, not by many a hundred acres, now making good feed for the white-faced, symmetrically-built sheep, who are treated so much better than humans in these parts. Their lambs, flourishing exceedingly in the summer, 
are moved to kinder quarters when wintry rigours arrive. The human dwellers on the low lands can't send their lambs to the hills and downs, and he who walks and sees with understanding eyes needs only a little looking at the youngsters' complexions to tell what the cold wet marshes and the white mists do for this sort of youngsters. Pleasant places the Rye men's lines are laid in while fine weather lasts, pleasant enough to make me often wish for much racing at Folkestone, making excuse to drop over (by convenient trains, you know) to the colony on the cape point of a long promontory shelving on the edge of the Rother's course. A regatta was on as I arrived, the riverside "buntinged" up to the eyes, and the main street full of committee-menso I made for the marshes and the golf-links at Camber, where the process of vegetable colonisation I alluded to from Selsey gallops, absolutely gallops. There can you see shingle turned into pasture almost while you wait, and the yellowhorned poppies grow and the bugloss and the thrift and the nightshade feeding on air and carpeting the loose pebble beach with a network of vegetation, mostly "annuals," shortly to be starved out by the hardly perennial usurper turf, that turn reclaimed waste into pasture before Neptune knows he is in the hands of the landgrabbers.

Why the deuce could I not begin by converting the South-Eastern so as to get a timetable all for my own purposes? If I had I would not have come away hungering with gnawing desire to see Dungeness as the Micawbers saw the Medway. "Over there," said an enthusiastic native gentleman of Kent, 
or Kentish gentleman, "they walk about the shingle on boards like mud pattens, which are not a bit like them, and before the shingle has properly left off being rolled along coastwise by the tide, an army of foxgloves jump all the space and stick themselves up on every square foot of their free selection. Miles of 'em you can see." Perhaps I could if I was there to see, but must content myself with the good old Honourable Artillery Company Captain's ballad's wish that that I may be there to see some day. Marked for examination are Lydd and Appledore, and the moated Castle up the Rother, and a lot more (which I had to miss) of Rye and Winchelsea, before the painters make off with their remains. Not much can be left shortly, for artists by the score were busy, every man of them, and women, too, taking bits for all he or she was worth. Rye suited me, and its George Hotel, pretty much a fellow hostelry to another "George" at Knutsford - Mrs Gaskell's "Cranford." An excellent house this first, with capital lamb (I never could believe in Kent lamb being so good till I tried it, but the lamb du pays is highly commended), and an old-fashioned assembly room, adorned with a musician's perch, twin to the one at the Cheshire Knutsford George. This hotel would give proper surroundings in which to read Mrs Stepney Rawson's charming tale of old Rye, "The Apprentice."

Did I do the Ypres Tower, and the Land Gate, and the Mermaid Inn, now a private hotel, a reservoir of old furniture in its own home, and the queer corners and high-walled gardens and the "kidney" paved lanes called streets, and the patriarchal coasters and the Strand? I did as 
fast as I could, so destroying the repose that marks the house or town of Rye. Also I did Camber's ruined castle, built by Henry VIII., whose brickmaker must, I think, have rung in and used up a stock of old Roman tiles, a mediæval watch-house of circular scheme, ancestor in some back-handed way to the litter of martello towers dotted along the shores which round our coast from Deal to Margate span also on to Pevensey and Eastbourne. Quite in American fashion I ticked off at a canter Winchelsea's gates and New Inn and church and crypts and workhousegaol, which must have been a monastic house some time or other, the almost tropical luxury of plant and bloom, and John Wesley's ash-tree. I was going to skirmish over to Fairlight on the way, and look up the chalk cliff next to Winchelsea; but, you see, the railway company hadn't taken into consideration the possibilities of racing folks' rapid touring with a notion of settling down another time to take the sauce on the strength of a sweetener on the pickles. I felt it hard, deuced hard, to be unable to help myself to these other good things offering all round. (Did you ever come across the longshoremen's sweetly poetical realisation of the situation? "Sentenced to live in a cookshop with your mouth sewed up," they put it.)

Perhaps after reading my very sketchy Notions on Rye and Ryeabouts, folk doing Folkestone may fancy to circulate to the little town. They can manage all that by persuading the railway company to help itself to trade easy to be cultivated. I fared well on small limits, but then I made up for being obliged to quit early by doing Ashford, and the clean road, through 
clean country, among clean trees, clean fields, clean farming, clean houses, and clean peasantry to Westenhanger. On the march I included a call at a church, where every text-and many are illuminated in fresco on the walls and pillars -is cheerful and hopeful, and a man can go out from them conscientiously free to feel as little miserable as circumstances permit, and, if absolutely jolly, no worse a sinner than he is obliged to be. And that's all-nay, wait a moment-I forgot the clean, brisk, cobwebclearing breeze that somewhat discounted jolliness.

I don't know what such a mighty swagger place as Eastbourne will say to being put in the same chapter with little old-world Rye. Eastbourne is one of my unlucky places as to weather. Somehow I always get under streaky weather there, arriving in sunshine and a balmy or clear frosty atmosphere good enough to tempt a cripple to try and hop because it makes him feel so lightsome, and finish with bitter gales searching out and finding the rheumaticy patches in my poor old bones what time the stormy winds do blow at me cutting rain, sleet, snow, or hail. The old place I knew when I was in the hobbledehoy stage. Then its best friend-which was, and is now, the Duke of Devonshire-could scarcely have dreamed of bringing it, even by unceasing liberal nurture, into so splendid mature personality as it has reached. Success worthily attained makes a grateful spectacle, and Eastbourne the Successful in the forenoon of a brilliant brisk day in April was comforting to contemplate. Moreover, I had a good time on the way there in Willingdon Church, whose 
Ratton faculty chapel-I take it to be a facultyis worth a long pilgrimage to visit, with its memorials of the Parkers and Freeman Thomases, also a priceless muniment chest poked into a dark corner as a store for firewood and mean odds and ends. Further, I promised myself to look up Mr Lewis, the celebrated South Coast sculler, and get him to let me look over the Eastbourne Rowing Club's boats, craft in which I am greatly interested, and had thoughts of striking across the hills to the Jevington stables, also Batho's at Alfriston. Alas! the light was turned off the "old min." Mr Elements became distinctly unfriendly; going on the hills was unwise, so I started off on a long walk. What luck do you imagine came my way for fifteen blessed miles? I was in the wake of a motor car which wouldn't go except by fits and starts, but went enough to be always just ahead of me, jibbing, or doing something else refractory, at short intervals, and going again as I came near, just as if I was the starter's man with the longthonged whip. I was following a hot drag of methol for hours, and don't want any more walking in that way.

One of the last names I should expect to hit upon came to me at the Eastbourne excursionists' favourite resort, Litlington, as I was making for Alfred's Town, which, authority says, was someone else's. Colonial brothers who happen to go that way, you must visit the churchyard and pay your respects to "Charles Joseph La Trobe, Esq., C.B., first Lieutenant-Governor of the Colony of Victoria, Australia, who died at Litlington on December 4, I875, aged 74," and was buried there. Born much about at the opening of 1800 , 
was he not? A hundred years in the history of the Old Mother Country means a lot. What has the nineteenth century meant to Young Australia in its advancing? The gulf between the days in which Charles Joseph La Trobe was LieutenantGovernor-I presume this was the La Trobe known as Governor La Trobe, after whom the street in Melbourne was named-and the present year is almost impossible to realise in its vastness. One may safely reckon that when the to-be Governor went out there was no Victoria so catalogued as an independent colony; Separation Day had not arrived; far the larger part of the great continent by now brought into profitable use was terra incognita; sailing ships took nearly two-thirds of a year to get out from the Old Country, and, if they arrived in the days of the gold rush, might lie and rot for want of hands to work them back. Australia had been made the rendezvous for the scum of the world because of the diggings; at the gold fields-all alluvial workings (mining in the rock was not dreamed of, and machinery consisted of a cradle and bowl) -lucky ones made money in lumps; the mining army as a body earned rather less than labourers' wages ; said army was somewhat more rigorously bullied by jumped-up police officers than convicts ; regular industry was at a discount, and Governors, also Lieutenant-Governors, had to fight very hard to get their colonies recognised as worthy of respect and entitled to fair consideration by the home authorities.

Bearing in mind how events have shaped themselves down under, it sets one thinking to fall across in an out-of-the-way rustic English hamlet the tomb of a character notable in 
Australian history, when making it was rough work indeed. Austral-Colonials "come home" to England: doing the return journey is called "going back." The homing instinct strong in our race is manifest in these two expressions, is it not? Most English-bred Colonials must, I fancy, yearn to "come home" when there is no chance of making the return journey and "going back," because time has come to end all travel. About this is always to some of us suggestion of the pathetic, even when poor, despised John Chinaman is the sacrificer to home hunger, and can get no nearer to his heart's desire than having his bones shipped to the Flowery Land, part of a wholesale freight of such remains.

I wonder if ever our rulers will leave off cramping facilities for learning swimming, and practising that most valuable art may at last wear into our ruler's hearts. For years and years the Referee has begged that bathers who cannot swim and those who can should be given a fair chance. The Life-Saving Society, started by Messrs Henry and Sinclair, has done wonderfully good work in extending opportunities in certain directions and arousing sympathies which wanted wakening. Certainly the society, though opposed or discouraged in various ways, has at least brought swimming's claims more before the people, who might give it a lift if they pleased; but with all tried and done you find genuine support rare where it should be strongest and most frequent. To get the best swimmers you must turn from the natural school for them, the coast, and to the inland counties. To understand what proper encouragement means, go to Lancashire. Take Manchester, as we under- 
stand the assemblage of municipalities collected under the city's style, and look at its public baths. Then turn to places such as abound on the South Coast-Brighton and Eastbourne, for example. Encourage use of the natural advantages their littoral offers? Not much, unless setting encroaching, offensive, or vexatious restrictions mean promoting bathers' interests, and stringing together a row of prohibitions, limitations, and penalties is calculated to act as a stimulant. True, Brighton has a Corporation fresh-water bath and Hove's municipality a very fine seawater affair, carefully constructed of an odd length to spoil it for racing, but not a penny is spent on turning the shore line to advantage for sea-water baths. As to the "open," unless you are willing to "go in " earlier than the most like or later than suits the majority, you are left to do the best you can for yourself from bathing-machines.

Eastbourne, though extremely arbitrary and dictatorial in its arrangements for bathing, flourishes. Brighton's best friend could not have the audacity and mendacity to declare that it was "going strong." The reason why the latter wilters in the heat of opposition and rivalry is not far to seek. The high-class business that made its fortune has been driven away through interfering with its convenience, also by cheap tripping, and cheap tripping does not keep trade going. It used to be one of the places for children because of its beach and sands, and a popular resort for boating, pulling, and sailing. The big steamers now serving well, probably gave more in themselves than they took in ruining the longshore working-boatmen's trade. Besides, the perhaps necessary new system of 
concrete groyning would have knocked the latter out in any case. Still, the small boating has been knocked out and the foreshore is not what it was at all. As a watering-place old Brighton has vanished, and given way to a new, which is by the sea, but not seaside, as it used to be. Who would go there for sea-bathing except perhaps fine swimmers who dare venture from the piers? You would not select Brighton as it is for teaching youngsters swimming, nor for any bathing from the shore, with a "machine" for dressing-room-at least, not as things are now. Still, I wonder if history might be made to repeat itself. Brighthelmstone grew from a little fisher village into a great town. Why? Because of its sea-bathing. Suppose the authorities, who are trained in laying out money in big lumps, tried taking in hand the splendid advantages lying literally at their feet, and set about making the town what it might easily be-one of the finest sea-bathing resorts in England. They need not find the capital themselves, I fancy, if proper plans were prepared and sites for open-air baths granted. The resort is there, and the sea. All that is wanted is to make the bathing easily practicable.

Instead of providing sufficient accommodation, municipalities, conservancies, and such keep driving bathers within narrow limits of space and hours, all of which means waste of good material. For, as has been pointed out so often with regard to modern education at ratepayers' expense, after spending so much to educate our Board scholars we ought at least make them go to Nature's insurance office to cover against risk of drowning. Find the kiddies a place to learn, and they will 
present themselves freely enough for schooling, you may depend upon that. Unfortunately, our method is too often to warn them off their natural water playgrounds. More's the pity-and shame.

Do you know that if only your eyes could take a slant down the farther side of a higher point, you could see Eastbourne from Brighton racecourse? The quality of the light on the South Downs is marvellous. Sometimes, between the light and the genial balmy air it is a privilege to be alive, to sit and absorb health and tone by the bushel, or however you measure it. Not often on a race day can you make out so very much beyond the cliffs over against Seaford, scraped white in making the new roadway. But I have known the sight carry right to the highest point of the downs looking on to Eastbourne. All the same, not a trace of the several towns and villages en routeOvingdean, Rottingdean, Telscombe, Newhaven, Bishopstone, Seaford, and those between the Ouse and Eastbourne would you see, because of the hills in between. Save for an occasional farm building or so, the whole territory might be a deserted waste. A nice, long, droughty walk that represents, to go between the two points noticed, one of the most tiring I know on the road, as also if you fare along the switchbacks made by the chain of hills, locally the Seven Sisters, but worth a score of the macadam taken that way. By the road you miss the interesting part of the Cuckmere haven, with its fishing river, which mostly silts through the shingle bank thrown up by the sea's raking. Neither do you lie in the way of foregathering with the coast- 
guards at the stations-gentlemen all are these patient, dutiful, public servants, and good to chat with. You can have a word at two or three more stations before you reach the last hill-crest after passing Beachy Head new lighthouse, which, you know, is not the one on the high land up by where Eastbourne races used to be held, but a later beacon-house set down on iron piles under the face of the cliff. At first sight you would scarcely believe what is fact-viz., that its lowlier situation is better than the lofty one, because the spray and mist do not tell so greatly against the light's carrying powers. 


\section{CHAPTER X}

\section{AROUND HAMPTON COURT}

ON a certain Easter Monday at East Molesey I was busy observing the populace (bless their hearts!) and levelling myself down from a ridiculous imaginary platform, and writing myself down, too, for a prig, which is, I take it, the latter-day equivalent for a Pharisee. There wasn't much of the Pharisee left about me by the time I had finished lecturing myself with some very pronounced Bank Holiday folk for text. It was like this. I happened to be one of a little group observing the manners and customs of a small party of East-Enders, who were, so to speak, piping and dancing in the market-place and doing so like anything at ten o'clock in the morning. For market-place please read the pavement outside Mr George Brown's Prince of Wales' Hotel at Molesey. Mr Brown, a relic of the ring, is, I am glad to hear, getting into good health again. What a many years have flown since old George Brown and Alec Keene began racecourse refreshment catering! Keene and Brown's booth at Happy Hampton was a great institution, with " everything iced but the welcome," to quote their advertisement issued for such occasions. But let me get on with my festive party. 
We, as I say, observed them, and did so in quite a superior de haut en bas manner, because their ways were not conventional according to our lights. One gentleman doubled the parts of dancer and piper, or what did as well, performer on the mouth-organ. A second and two ladies made up a quartette, who did step it most vigorously to his music. "What a sight!" says one of us, and "What a sight!" we all said to ourselves-at least I did till I asked myself a question - several questions, in fact. In the first place, I came to wonder whether any of us could do a step so well as the least expert of the four, or, for that matter, whether we could do a step at all. And, assuming that a representative might be found to stand up with the East-Enders, whether it was not a thousand to one against his being equal to playing the mouth-organ in good time and footing it also. Granting that extremely unlikely matter, I am quite certain that not the best of us would have had a chance in a match against the ladies, all to start fair, off the same mark, at level weights as regards clothing. When you came to think of it, the performance was wonderful, for the ladies had on thick dresses of a draggy, velvety sort of material, the very last kind of equipment to favour athletic exercise, and don't you think that their dancing was not a very athletic exercise indeed, because it was. Moreover, like the famous gentleman, on the top of the wig was the hat, and such magnificent structures as theirs require, you would fancy, most exact adjustment and balancing. But, bless you, not even the final high kick, the full stop of the saltatory display, so much as put a feather out of place. 
All of this business was very wonderful and clever when you valued it on its merits, not the least wonderful and admirable being the life and go these hardworking folk-I dare swear that they were jolly hard workers-must have in them to feel like kicking up ahind and afore and doing shuffles and rocks and all manner at ten A.M., and to the melodious breathing of the mouthorgan as aforesaid. I stood to scoff or something like it, and remained to envy very much indeed, so that the spirit was willing to make straightway to the green at Hampton Court over the way-I mean over the bridge-and join in the sports there in progress. The flesh, unfortunately, was weak, so I perforce contented myself with joining as a spectator only of the wonderful energy displayed. If looking on will enable you to do a thing such as skipping, I ought soon to be an expert, for I looked on till I started almost too late to get to Kempton in time for the first race, and got along feeling a bit small, because, running myself a trial on book form against the crowd so many generally rather pity than envy, I found that they could do, and do very well, too, a whole row of things which I cannot. But I will qualify, though, if I die on the thrack, as a bogus champion walker used to say when endeavouring to beat Charley Rowell at Madison Square Gardens, New York. What was the chap's name? Something like Campagna it was, and his way of putting things was, "give me more champagne" (fine stuff to do a six days' walk on!) "and I'll bate him if I die on the thrack!" But champagne or no champagne, please understand that I do not dream of soaring to the heights of the mouth-organ by itself or taken in 
conjunction with the stepping-if, that is, I am to be the mouth-organist.

I wish, I do wish so much, that some of the folk who are led away by "anti-" agitators, and so throw in their lot with those often artful, scheming, professed moralists, would come and look at one of our Bank Holiday racing crowds, for instance at Kempton Park or Hurst Park. If you make up your mind to find fault, you could, as John Hollingshead said of the captious person, grumble about the cut and fit of your own halo; so I do not say that no fault could be found among all these many thousands who made long journeys, had a whole afternoon's racing, and then most of them must wait getting on for an hour before their turn came to join on the road in a procession of vehicles three miles long and not doing that distance per hour. You could, I repeat, pick out, I dare say, flaws in a grand general effect; but from personal experience I can say that the crowd's good temper, nature, and humour were something to admire, and their behaviour to be nationally proud of.

Poets are, I fear, apt to be very material in their likings, and, like human beings, inclined towards treating by preference what you may call comfortable features of their territory. For instance, they love to dwell upon smiling plains (with a good deal of emphasis on their fruitful character) bringing forth the good things of the earth, the corn, and the oil, and the wine, that maketh glad the heart of man, and maybe, his head very sorry. By all means let them do so, for without this land, by implication good, we should go short, and they being a superior order, would feel the poverty most, as they are to be 
considered before everybody else. Good fat land is a great gift; all the same, I often feel that we -I am speaking now as a temporary dweller where commons are many and wide-_ought to be grateful for the bad and barren. We have, you see, followed those who, if it had not been for precious poor stuff being mixed up with the other sort, would not have had the use of any land at all. As we are all descended from the very highest aristocracy, and could prove that same if we only go back long enough, I shall not be hurting anyone's feelings except in a family way, in writing that the great folk, who permitted the inferior clay to get what they could out of unproductive sandy wastes and such, were liberal only to the extent of giving away what was of no earthly use to themselves. That explains why where the ground is bad you get good measure of common; and, according to my view, we of this present century have to give thanks that such a large acreage was no good for the lord of the manor or other big man to use, and not worth anyone's grabbing before our natives left off wanting a bit of ground good enough to cultivate round their dwellings, and, let me add, ere golf came to be in vogue. We should not have any commons now to speak of if golf had been popular a century ago. Look at Weston Green! There is practically no common left since a golf club established itself there.

In those same parts an old-time advertisement in which I took considerable delight has been disestablished. That is, the ancient legend set forth for many years on the pub. near the corner of Weston Green as you go from Thames Ditton to Esher. I felt several pangs on missing 
the accustomed invite which formerly adorned the Harrow Inn. I forget at the moment quite how it ran, but know that it began: "Come, my dear brother, let's comfort each other." Then it went on something like this: "Here's wine and good ginn" (gin with a double " $n$ " or " $n$ n," as the School Board says the repeat should be expressed), "Brandy within. Cyder and twopenny fit for a king." A friend, kind enough to keep me posted regarding sporting news as chronicled in Chicago, wanted to know whether the Alma on Weston Green-or Cow Marsh, as some call it-stands where it did. To that query I could answer that the Alma is in one respect like Scotland, in that it does stand where it did. But-and this is a dreadful but-under new management the sale of "Grandfather's Ale" has been discontinued; at least, so the polite new boss told me last time I ventured into that part of the country where strangers, golfers claiming no local connection, play their game on a bit of common cut up by footpaths as is a Union Jack by stripes. "Twas with a heavy heart that, after seeing the "Orate and Vigilate" on the almshouses opposite Thames Ditton Station, allowed to be covered by creepers, and so hidden from the gaze of wayfarers who might profit by the pious instruction, I passed to the Harrow and found "Come, my dear brother," etc., not to be found, and going round the corner to the little ale-house by the pond, and Hansler House, where poor old Charley Hewitt used to live, then heard the sad news that the grandfather's clock had stopped, never to go again-I mean that Grandfather's Ale at the Alma was disestablished. "Iconoclasm," says I, "is making my little world 
too uninteresting," and fell to wondering whether that had anything to do with the gosling crop on the common falling so short that I was only hissed at once by my much-respected friends the ganders and geese, best of fathers and mothers, and at that conspired only by a limited liability company of old 'uns, who mustered no more than a couple of "gulls" among them. Probably the changes are breaking the old birds' hearts.

Taking my ease at my favourite inn, the Mitre, at Hampton Court at Christmas time, I fell areminiscing. Natural enough, lodged in a house from which radiates sport galore, and in which it centres. At the Mitre you can have, are sure to have, whatever is written on the bill of fare, are certain to have the best procurable of that item, and to be treated, not as a number, but as a member-a welcome guest, one of the Mitre's connection, whose tastes and fancies are humoured and remembered. I found myself primed, filled up to the bung, with memories of good sportsmen to whom the Mitre was a happy centre for rendezvous. Subjects? Why, bless you, I could write for a month round Hampton Court and not write myself out.

How might I let myself loose about the old house, with its silver show and its old Sheffield plate show-better, in my eyes, than the other -of Jack Sadler, the L.A.C. champion, son of the Mitre; of Coombe over the way, at the Greyhound, who walked so well; of the Hampton Court Harriers; of the Molesey Boat Club, with old Joe Sadler, trainer; the Canns, the Blocks, the Kents, and the Pipers; and Alexander Pain, who won the Wingfield's; Gilbert Kennedy, who did ditto. Then there were in the long ago the 
Oscillators-who were they, the good crew? I almost forget. There were two Shoolbreds, I think; Willy Ward, good man, about now, who wrestled someone at Henley, and beat him-Jem Robey, was it? I forget; the Leaders, sons of the chairman of the Alhambra directors-one of them, the fine swimmer, was drowned at Staines, a champion swimmer almost. Francis Stepney Gulston, afterwards to be captain of the London Rowing Club, that finest-I make no exceptiongentleman oarsman, who stood out by himself as a waterman, was an Oscillator before he moved to the London Rowing Club. I think I am right in saying that Gully, who was, in my eyes, the greatest of all amateur watermen, went to Cambridge mainly and merely to row. Well do I recollect poor dear old Jemmy Moxon, who worked hard to start the Skating AssociationMoxon, LL.D. I shall never forget his description of Gulston's taking up residence at the college with a pilot jacket on, a bottle of gin in the O.P. side pocket, and a bottle of bitters in the prompt. The sapient authorities would hardly give him a chance in a college crew, and as for the 'Varsity eight, they wouldn't look at himhis style, those clever judges said, was too professional.

Then there was the pro. side, fully furnished by the Taggs. Bless you, merry gentlemen, start me on the Taggs, and I will go for a Beacon Course! Of old man Tagg. I do not enlarge, though I must remember the time when telegraphy was not what it is now, pigeons were useful, and a Cambridge crew went under Hammersmith Bridge-was it in Griffith's year?-with a big lead, and the pigeon bearing a light-blue ribbon 
caused the Count to bet freely and lose. I think it was in Griffith's year, when, as I recollect, he rowed all his men right out, then tried to pull the boat all alone by himself for half a mile or so, and spurted, and spurted, and spurted. There was Jack 'Tagg, one of the finest, handsomest men I ever saw. Jack, the ever free and frolicsome, who once whitewashed a donkey on the fifth of November, bundled the creature into a barber's shop and wanted him shaved, saying that he was already lathered!

Dear me, how old am I ? I used to own wager-boats when Jack Tagg was racing. Poor old Jack has been dead years and years. Tom, of Tagg's Island, has gone too. A rare good sort, a fine sportsman, who could walk, run, and fight when fighting meant P.R. business, and would take on anyone who upset him, weight of no consequence. Tom, who was one of a Thames Championship four, was an inborn genius in devising craft, from a skiff to a steam launch. $\mathrm{He}$ was an honoured member of the Institute of Naval Engineers. Also he was one of the best friends I ever had. We once were as nearly as possible shipwrecked together during Mr Billy Innes's International Regatta. I was knocked off his launch into the water, had to swim ashore, and was ordered out of the telegraph office at Mortlake because I made the place wet. Poor old Tom kept a special dispatch-box of mine which was rescued, and preserved it as a trophy. I wonder if I could swim ashore now if I was cast into mid-Thames at Barnes with the water churned up by a score of steamers, and old gentlemen throwing trifles such as tin buckets and boat-hooks at me to represent lifebuoys? 
How many of you recollect little Jerry Hawkes, one of Bill Richardson's light-weight pets, I believe? I remember Jerry and George Dove, who was humpbacked with muscle behind his neck, having a tremendous fight with the gloves at Bow Running Grounds on the day when Bat Mullins-Bat with the synonymous ears, the abnormal reach, and the wonderful endurance-met a Life Guardsman, who, had he known the tricks of the trade, would have won for sure. Bat is about teaching, and a good instructor, too; but this was nearly thirty years ago. Who reading this will recollect the promoters of the show; Old Bill Richardson, Harry Read, the runner of "Bell's Life," and one Preston. I can see the Bow Grounds and the sparrers as I write; so I can Jerry Hawkes, up on the barge-walk just above Molesey Lock, when we put him on to a try-your-weight machine pitched on the tow-path. Jerry knocked the whole apparatus bang into the river. Then Molesey Hurst was considered to be common land, and about it hung all manner of traditions of old fights, for which see your "Boxiana" or "Fistiana." The vicar of the parish, on the day I name, took the chair at a banquet after an amateur swimming race, and the first thing he knew was that he was hit in the eye by a hot baked potato. Such were the manners, or want of manners, of the British amateur then.

Hampton Court?-why, when Kempton was first started, and Sandown, you couldn't get a bed in the Mitre, or the Lion, or the Greyhound for love or money! All the Newmarket trainers pitched there, as did many of the big owners and jockeys. Such a thing as trainers making 
London their headquarters for these was scarcely dreamed of, and most of the well-to-do who came to the meetings drove each way.

Do not think that with racing reminiscences I can write myself out, because if you do you are much mistaken. There is the angling sect who swore by Hampton Court as a centre. I am a bit of a Philistine on fish-catching, cos why, I have lived contagious to the Thames on and off for very many years, and never yet saw more than three good ones landed. This is not to say that the fishing correspondents who turn in thirty dozen of dace, forty ditto of roach, seven score of gudgeon, a creel full of barbel, and specimen samples of jack, all taken by "a gentleman fishing with So-and-so," depart from the truth. I take those reports as they come. They do not enter into this argument when I say that I have known two ardent fishers-the late $\mathrm{Mr} \mathrm{J}$. P. Wheeldon and our present, may he live for ever, Mr Henry Smurthwaite-who loved the Hampton reaches, and made big takes there.

Poir old Wheeldon! most fertile of writers, a sportsnan bred and born, also educated that way! he was a sportsman, a marvel at fishing, and a good 'un all round. He could do almost anything. At the Mitchell-Sullivan fight, J. P., who was reporting it, was there all through, and asserted himself in the cause of fair play. Once came $\varepsilon$ chance of interruption-as the word used to be understood - and interruption that day meant very ugly work. Wheeldon said, says he, to the chief would-be interrupter - an old-time pro., who would as soon chew your nose off as argue c point out logically- "If you don't shut your muth, I shall hit you on it." Good old 
J. P. Wheeldon! He meant what he said. Hampton Court or Molesey, which is only just t'other side of the water, claims one of the finest, if not absolutely the best-I never knew a better - stroke in amateur boat-racing, and that is $\mathrm{Mr}$ Willie Kent. His record as a stroke for Oxford and Leander stands by itself, and no doubt, but for the folly of the Henley umpire when Leander was left at the post and the American crew let go away by themselves, he would have been associated with a series of victories not at all likely to be paralleled. A rare sporting centre is, and always was, Hampton Court, with which you must include Molesey.

As I sit giving off these notions I think of the great growth and excellent management of Molesey Regatta, with which firm I had a feud for years. Mentioning it brings to mind my dear dead and gone friend Jemmy Milner, suavest of secretaries, handiest of all-round men: good old Jemmy, who, a bachelor, had for family all the children of the village, and was appointed by them entertainer and bosom friend to all. Then I must not forget the late H. B. Bromhead, of ours, who was a very useful all-rounder, and not at all averse to putting 'em up and takng his chance. Brom. was an enthusiastic fisherman. The Royal stud in Bushy Park and the Home Park has long been wiped out, so has the Spelthorne Coursing Club. Fancy cousingand good coursing, too - in the Home Park! Were ever luncheons so good as Mrs Mooe used to send over from the Swan at Leatherhead for the sales at Eltham in the Blenkiron days, and on the occasion of $\mathrm{Mr}$ Tattersall's offerng the Royal Rats? I do not think they evir were 
matched. It seems only a day or two ago since I was talking to $\mathrm{Mr}$ Scott, the stud groom of the Royal establishment, on the day that Springfield died, or when the boys held up and calmly went over the whole big ferry-boat load of people being taken across from Hampton Court to Molesey Hurst on a Hampton Court race afternoon. They were told to think themselves lucky they weren't put into the water as well. What an awful meeting that used to be! The wonder is that someone was not killed there every ten minutes. Then there was-but I shall be accused of falling into my anecdotage.

Let us take the Mitre under another, a summery aspect, and a very nice place to get to Epsom from. To the useful plodder, I think no better starting-point for the Downs can be desired than Hampton Court. Many a time I have tried it. If a body knows the route, no nicer plan can be for a visitor from Northern parts to pitch his tent at than the Mitre, best of hotels within telegraphic reach of London-at least, one of the best-and with a light heart and a thin or thick pair of breeches, according to taste and the wickedness or otherwise of the weather, go merrily over the footpath way and ditto over the stile-a by Tanner's bridge, which gives one of the prettiest bits of Thames scenery, on across the Mole and its understudy the Imber, by Imber Court, adorned with an Inigo Jones house, which looks as if it were built for suburban residential purposes by an architect of metropolitan taste and late Victorian period. Then cross to Weston Green and the pond into which a late amateur coachman quite frequently speeded his parting guests, telling them to go on a dead 
straight line to the lights of Esher Station. You can keep on grass almost all the way to Claygate, and shortly after strike across the Common, which, so far as general enjoyment goes, the golfers have managed to withdraw from popular circulation; continue through Lord Foley's park, and thence on several different lines into Epsom by way of its Common, where steeplechases used to be run ; past Clay Hill, where Eclipse passed the earlier years of his stud life; and once in the town-well, all roads lead to the Downs, but some are mighty twisty.

A long journey, you say. Well not so long. If it is nine miles, and if you can spare the time, how may you spend it better, given fine weather; and I defy you to find a pleasanter resting-place after the return journey than just about Hampton Court, in the cool of the evening, or early in the morning before breakfast, paddling on the river or ranging the park among the deer, or strolling in the Palace gardens, which are most beautifully kept up, and seem scarcely appreciated at all. Grood business? It is good business indeed in the summer weather, or spring for that matter. To begin with Molesey, there song sends you to sleep in the Mitre overnight, and wakes you up in the morning. First of all you become aware of a paddling, scuttering sort of noise-ducks busy in the shallow waters of a little creeklet under Hampton Court Bridge, and then a good deal of quacking and wing-flapping. You don't need get out of bed to see what is going on amongst this industrious family party; but next comes an arousing diversion, by reason the man on the horse and the man on the barge being towed up against the stream differing on 
the subject of steam and direction. You must look out of window so as to discover what sort of mess the two are making of it between them, through the chief engineer driving the horse slacking up too soon. The hotel proprietary thrush starts singing, and an early swallow or two are up already, which is more than can be said for riparian residents, judging by the general lack of smoke out of the chimneys. Where the breakfast fire is occasionally alight, up goes the smoke slowly and dead straight - we are in for a hot day. You take another turn at bed, listening to that musical soother, the weir, when a winch starts clicking right under the bedroom window, and on the chance of a fish being at the other end, the alarum induces another excursion to find the winch a mowing machine that clicks, not clacks, and is managed by a good, good yellow collie dog with a nice broad nose-none of the up-to-date show ones with pointed masks as of a starved fox-and his under-gardener. The man does the pushing, the collie bosses the job, walks solemnly across from edge to edge of the lawn, and now and then expresses approval of his lieutenant's industry, but always keeps an eye open to spot malingering, a complaint to which gardeners are dreadfully subject. Sweet is the smell of close-shorn dewy herbage. I fancy I can just get a whiff from the lilacs half out and the daffy-down-dillies; no mistake can be made about the wallflowers; the little white clematis is well forward, and the horse chestnuts soon going to be, for their bloom spires are whitening, while already the apple blossom is making a good show of its sort. The sun is warming the air kindly, the south-wester-a real one, not an imitation 
north-easter-suggests possibility of a shower or two, so to make sure of a little good time while it lasts, up you get and be out in the open. And all that and a lot more you can do as part of an Epsom outing. 


\section{CHAPTER XI}

\section{IN AND ABOUT EPSOM}

I AM afraid to say how often I have been at Epsom, in and out of race times. I used to think that I knew all about it, from the wicked lord story to the goldfish in the ponds; from the oldest house to the new clock building made to accommodate the fire-engine, and built a few sizes too small, so that the fire-escape has to lean up against the tower outside ; from Amato's grave to the Marquis of Epsom's open-air studio, where he used to paint his railings so artistically ; I knew it all-everything except the number of different ways for getting between the SouthWestern Station and the Grand Stand. Epsom is an old typical Surrey town, with just a cut of Tunbridge Wells in it; one about which you might profitably spend a good long while in exploring. You can't beat these places, which before the days of railways were just far enough out for London's rich City merchants, whose substantial houses and fine gardens occur all over Epsom Town; and you can't beat the place for air-good, strong, wholesome fresh air, with plenty of character; not the sort like Brighton's, which is associated with a blinky 
feeling, nor the bilious tap frequently turned on at Newmarket; but just a good, honest, robust, healthy, hearty sample calculated to make you eat well and sleep well; and if you deserve such luck as getting it, be thankful that your lot is not cast in a depressing place like-well, we won't mention names, one can praise Queen Ebba's town without running down others.

I only wish I might pitch my tent up near the top of the hillside, where you get the southerly breeze straight from the sea, and often tasting of it, too. Cold? Oh! yes, cold it is, of course, in such weather. It can be cold in this part of the world, which "has quite a name" for that sort of thing. But, locally, pride is not taken in the superiority of cold on the hilltop. The spot specially celebrated for it is away down on the flat by the half-mile Bush between Epsom and Ewell. According to tradition, which preserves opinions expressed by stage coachmen (who ought to know, ought they not?) about weather, that was the bleakest, freshest bit between London and the coast, take which road you would to Portsmouth, or Worthing, or Brighton. As a rule, my chief trouble with regard to Epsom is to get out of the place when once I am landed there. I think it is at its best about the last week in April, say during the Spring Meeting. I like it then better than in Derby week. Of course the "country," as people say in speaking of vegetation's progress, may be at the time of the earlier fixture a month late if the weather has been unkindly. But sufficient advance will have been made to make the Surrey country (where is better?) very beautiful indeed. Nowhere do you 
get such good opportunities for enjoying Nature's best adornments as in an old suburban town. There you have more variety than in the country proper, because of the specimen trees and shrubs imported.

There are many ways of approaching Epsom. The last time I did one of the best, which takes you to and fro Epsom from town without striking the general traffic, and a charming walk before and after racing, but, upon my word! the bad almost outbalanced the good, and I feel equal to little more than organising a national petition to the King and his Parliament to do something for us. Cannot somebody throw the right sort of oil on the troubled dusts, or, what is the alternative, make footpaths everywhere from which all wheel traffic should be forbidden? Truly, I am so disappointed at being cut off at almost every step from taking outdoor pleasure that I keep searching about for refuge, of which now have I none. For the automobilists, who hate dust as much as anybody else, are now illustrating the old idea of the Royal Academy being crowded on a Derby day, because nobody would be there - at the picture exhibition, I mean. The byways, narrow as are many, are crowded with the car-eerers, who, for the same reasons as mine, take to them to avoid the main arteries. A horrid pity I found last week's disappointment, for I had my own route all on my own, which I am selfish enough to like, barring a jolly companion. Give yourself time, and you may have some of the prettiest walking in Surrey before and after business on the Downs commences, and very cheaply too. My latest plan is to drop down by an early train on the new 
Guildford line to Claygate, Oxshott, Cobham, or-but this last makes it too far for mostEffingham, and walk from one of those points. If you only desire to see country from the train and travel in comfort, free from crowding, then you can change at Effingham and rail it to Epsom. But for the toddler a good route offers from each and every one of the depôts named. I think I once gave the log of a trudge between Claygate and Epsom's Town Clock. To that route are three or four variations. I do not take it on now, because Claygate is getting townified; the pretty, rough common has been jumped for golf, while an old road which led through the Prince's covers is stopped, and the covers themselves are apt to mire you up to the chin, or on that way, after so long a spell of wet as we have had.

My march was by way of Stoke D'Abernon, on Mole-side, with its pretty little church, where used to be a memorial to a brave knight. The hero, to show his chivalry, made solemn vow to please his fair lady, or somebody else, by slaying the first man he met, and timed himself so as to drop on to the next-of-kin between him and "the property," or his principal creditor, the King's taxes, his landlord, or somebody like that, quite of no consequence. For the gallant deed, t'other man being probably unarmed and out of training, he received a medal with a "bloody hand" on it, and gained enviable distinction. From Stoke you work up to Leatherhead Common, which is not a common, because it was collared by Act of Parliament within the memory of man, and is now being turned, some of it, into golf links and building land. Really, we are lucky to have any 
common land left, and must be truly grateful that golf caught on in the South so late. Had it been followed a hundred years ago as it is now, there would not have been a bit of our wastes left.

A lovely bit of mixed woodland is this enclosed Leatherhead Common, otherwise known as Pachesham Park. Just over the way towards Epsom is Ashtead (which adjoins Epsom) Common, a big bed of very stiff clay, in which oaks flourish, wild flowers grow luxuriously, and thorns are much at home. The water lodges, being mopped up as with a sponge, and gives the unwary many fancy surprises in the way of impasses where the grass grows green. About here, too, is iron, and so is the stuff that makes Epsom salts; in fact, on the edge of Ashtead Common is the old Epsom Wells, and in plenty of places you can get the delightful beverage first hand for the finding. Cross the Common to the village and you are soon in Ashtead Park, an ancient walled-in deer park, on whose borders are some rare pretty old-fashioned farmery houses. You can cut up a byroad from the park to the old Roman road which runs from the paddock to Mickleham, or, bearing on the low ground towards Epsom, pass in the gates of the Woodcote, and through its beautiful domesticated downland up to the corner of the Durdans estate. A little bit late as vegetation was, still, in all this I have catalogued was much to enjoy, and I ought to have enjoyed myself accordingly, but while I served my purpose in clearing the race traffic, being smothered five miles away from it, put me right out of heart. Instead of being truly grateful for the good I got out of the parks 
and the commons, I made my leading features getting bogged on the top of a hill, walking through a mile of midges on the edge of Martin Rucker's old place, and-well, I won't say any more about the motors for the present, but if relief is not speedily engineered what is to become of poor me, or how I shall be able to do my work, goodness only knows. I do not.

I have already described another route, that from Hampton Court. Going a more conventional way through Ewell, lo! and behold, as we went over the bridge which crosses Kingston lane, the road which takes you either to Kingston or round by Bone's Gate to Hook, Chessington, Claygate, Ditton, and the parts about Giggs' Hill, I saw an unmistakable Gippo whose identity I can swear to at long range. That was the Reverend Mr Dan Cooper, who used to carry on business in or about the Half-Moon Cricket Ground, Putney, and was a very useful scrapper in his day, also extensively engaged in the cokernut line. It is always like putting the clock back for me a score years-or, say, a score and a half-to come across this Gipsy Cooper-one of the Stockbridge Coopers, if you please, the family which the well-known aged gentleman with the orange silk bandanna round his throat and a large stock of view-halloas inside it adorned so many years. There was my old friend Cooper with a steam roundabout of fiery, untamed ostrich steeds, and all manner of diversions at the public service, also his name painted in big letters on the revolving machine. Business called me t'other way, but I would have liked to go and have a crack with $\mathrm{Mr} \mathrm{C}-$, and investigate as 
to whether an expert could still make sure of ringing the bell every time in the shooting gallery, and try if knack of sending the marker right up to the top of the try-your-strengthwith-the-sledge-hammer apparatus was a lost art or not. Friends, if you want to study a fine type of the English gipsy, you cannot find a better specimen than my Egyptian crony.

Epsom recalls a pet scheme of mine which strikes me as worth entertaining. Ponds of size are scarce nowadays in the district on which the monastical fish-on-fast-day old 'uns left their mark through large stews-still clearly traceable, chains of them-on certain commons. Both on Bookham Common, close to the station, made there when the extension line from Epsom to Guildford viâ Effingham was constructed, and on Epsom Common, where the steeplechases were run formerly, you find the plan of ancient stews with a section remaining. Barring the last of the chains, the lower earth wall has been cut to drain the higher ponds, and the sluices removed, so that the only sliding or skating on the former large area is on dry ground-the safest, I admit, but not diverting. Field for skating is very scarce, as is also water for fishing. If the commoners and others with rights of grazing, etc., could be induced to acquiesce in the scheme, one could by restoring these stew ponds at a trifling cost create great opportunities for amusement in the direction indicated, not to mention furnishing facilities for bathing. There used to be a fine series of pools within a mile and a bit of Epsom Town; these could be reinstated very easily, and no one the worse for missing a few 
acres of pasturage. Apropos of skating and the like, I used to wonder at the Sandown and Kempton directors, who might readily instal big areas for use in winter, when frost would bring them much profit. All required is to puddle the acreage to be brought into work, make a low clay wall, lay on water company's service, and wait till the time comes in which to flood the space. Turf might be allowed to flourish at other periods; no disfigurement would accrue, and now and then gate-money would roll in to help the dividends.

I bear nothing but goodwill towards golfers, but I do wish they could make some land for themselves, or have it made without wanting to take it out of stock. As I have previously remarked, golf's powers of absorbing common lands, or we will call them free wastes, is great. Not only ordinary common but in these enlightened days village greens can be practically jumped for the game, so that "aliens" who have no part or parcel, kindred or tie in the district, except membership of a club, do drive off peaceful inhabitants from exercising their lawful rights. Why, bless me! there would, as I said, not have been any commons at all if golf had caught on a century ago, and very likely no horse-racing except in great lords' and others' private parks. Fancy there being no Epsom Downs, as downs are understood-a sort of no man's land on which somebody was allowed to run sheep at his own risk, and Dick, Tom, or Harry might come and do jolly well as he pleased, how, when, where, and as often as suited him! It was an awful shock to me the first day I recognised that the Downs belonged to somebody. But what a 
terrible thing if we had no commons! Of late a power of land in the Epsom district has disappeared, or been retired behind fencing of sorts -acres and acres and acres, over which local folk had roamed at will so long as memory of man carries. But he takes who has the power, and can keep while law is so expensive.

I wonder how many who were at Epsom Spring or Summer Meeting have any idea of the extent of land over which the public is still permitted the indulgence of ranging; what the acreage and mileage is approximately, starting from, we will say, the top of Reigate and Betchworth Hills, and following the line of the ranges round to Box Hill over to Ranmore, along to Guildford, and from there through Ripley and Weybridge to the Thames, with return from Walton-on-Thames by Banstead and Walton-onthe-Heath. Practically you can take a line from Betchworth to Oxshott and right away down to Walton Bridge-say, fourteen miles-without touching more than a scattered hamlet till you get to Walton, and never be more than a trifle over twenty miles from St Paul's Cathedral. Of course, I am not saying that this is all common land. It is open country, though, with a surprising percentage of it subject to some sort of common rights, and that after wholesale stealing, as in the case of Letherhead Common-say, the best part of two square miles gobbled up in one Act (of Parliament), and the wholesale looting along Ermyn Street. It seems a downright shame that all these beautiful pleasure-grounds should be at citizens' convenience to use as they please, and they not so much as know about, let alone enjoy them. 
Lots do not even know the name of the hills where the race stand and courses are. It is the fashion, or was so, to talk of Banstead Downs as the place where the Derby is run, which is wrong. Some of the track goes over what must be Walton Downs, but barring that you have Epsom's. What a row there was about the odd bit! What a fearful overpowering rush and gush of condemnatory criticism launched at the head of $\mathrm{Mr}$ "Salamander" Studd, who, becoming possessed of the lord of the manorship of Walton, presumed to ask for a financial corner out of the racing's profits, claiming such as his due because some of it - the Derby and Oaks particularlywas carried on over a corner of what was his land, for purposes of the argument! If he had set fire to the Jockey Club building at Newmarket, blown up Epsom's grand stand and looted the cellars, also arsoned Messrs Weatherby's offices and their printing place, records, unpublished entries, handicaps and all, and started ploughing up Ascot, Goodwood, York, and Doncaster, the late owner of Salamander and father of the long family of Eton cricketers could not have been dropped on more severely. So far as the sporting papers went, and writers on racing in other publications, the gentleman, whose action would now be approved and taken as a matter of course, was treated as a sort of Ishmael and bandit combined. No one seemed to think that if this money required had to be paid, the consideration was worth the fee. As for sympathising with the Manor of Walton and its representatives, who for so many years had been giving something for nothing - a form of barter which the Grand Stand Association could never be accused by its worst 
enemy of going for-no one took that side. Remembering these things, which cannot have a second edition, because the company is now by right of purchase its own lord of the manor, I must laugh. 


\section{CHAPTER XII}

\section{AROUND EPSOM AND LEATHERHEAD}

ON a misty day in December when I looked up Mickleham, more fog was on the high land than in the valley through which the Mole flows, by hook or by crook, presenting, as it can, the anomaly of superficially stagnant pools, and almost dry stony shallows, between little waterfalls. A fine hunting ground for the student of old Epsom racing is this, right along from and including Leatherhead to nearly Dorking. Horses trained at a distance from Epsom used to be quartered for quite long visits and galloped on Mickleham Downs, not so long ago very beautiful going. John Scott was very fond of the district, and so were many Northerners before the railway days. I forget whether there was local connection between Mickleham and the dead-heat for the Blue Riband, which, being run off, saw Cadland beat The Colonel; but in the village you find the contest spiritedly depicted one side of the inn's signboard, and on the other the winner alone, his jockey in light blue and dark blue sleeves. I know no country anywhere more beautiful than this dale or the overlooking ranges in summer, nor a lovelier playground than 
the tract comprised in the title, Boxhill, and about ten times as large as its visitors generally think this part of the Deepdene Estate is. Deepdene itself, where Lord William Beresford lived, is farther along towards Dorking, and will long be remembered by racing men because of its plucky owner and the mark he unfortunately was the prime cause of making on our Turf affairs. To my thinking, the worst day's work in the history of racing was done when Lord William introduced the American jockeys into this country. I do not pretend that we were an altogether happy family up to then, but, most assuredly, we have scarcely ever known what it is to live in peace and comfort since.

The United States riders brought with them very unorthodox methods in addition to the forward seat, which was by no means their original invention, and I sincerely wish had never been exploited, as it was, to our discomfort. Without going into the old story of the reign of terror, during which our most trustworthy English riders' word made no weight against any Yankee boy's, and so long as an American was put up when the winning time came, all previous performances, including running horses pig-fat with such men as Morny Cannon up, were considered quite legitimate by Stewards and others, some of whom were misled and some wisely made their market, one could not help being reminded of the bad days. It seems but yesterday since I saw a Steward of the Jockey Club march into the weighing-room of the Rowley Mile Stand with his arm round a pigmy American pilot's neck; or the date of the other occasion on which the late Prince Soltykoff pre- 
sented Johnny Reiff, then a boy, with a handsome cheque for a meritorious win, and the little nipper, accepting the douceur, stuffed it into his pocket without so much as looking at it. I suppose you remember poor Prince Soltykoff's lament at the personal sacrifice of dignity necessary for an owner desirous of keeping in an imported jockey's good graces. "He," said the Prince of his jockey, "sit on my table and swing his leg, he smoke my cigar, call me 'boss,' and use my boots for spittoons, and-_But as we have somehow got to Boxhill, let us quit racing as it was and ought not to be, and get up by the old road-Roman, say the local folk, and likely enough, too, because Ermyn Street comes right along past Epsom's paddock down to Myrtle Hall at Mickleham, only half a mile or so away from the foot of Boxhill's grownover track. Likely, too, it was a Pilgrim's Way for those who, coming from Winchester over by Merrow Downs and the back of Ranmore to Burford, cut across to Betchworth on their road towards Canterbury.

Let every reader who does not know Boxhill make a great point of exploring this almost unique territory of down land, thickly wooded, in parts a dense jungle of yew and box, mixed with almost every tree that flourishes in England, and, in the open, showing detached specimens to which the like can scarcely be found. An eerie, mysterious, ghostly sort of gulf is the great gully on the left as you make from the road to the fort, or, at least, it was when I climbed up there with the mist lying, as one may say, in strata, the light varying from minute to minute, and no sign of life except birds stealing stealthily about 
from one shelter to another in the dense jungle capped with old man's beard, and straggling flocks of fieldfares silently passing over-too tired, I guess, to even say chac. Here, twenty miles from London, was as complete solitude as in the bush. Judgment of distances and measurements was mere guess-work, and, for all you could tell by sight or hearing, you might be a mile above the river level when you stumbled on a fort apparently built to dominate the valley if the real Battle of Dorking should come off, and forgotten altogether-kind of mislaid, like the two regiments left for fifteen years in New Zealand, on nobody's books but the PaymasterGeneral's. Signs of life, however, were discoverable in cottages put up adjacent to the battery depôt, and, I may mention, one began to get quite glad to strike something that was alive, even if it was only a kid that pretended to be frightened into dragging its anchor, and a couple of very warlike dogs, outwardly fierce little tykes but inwardly glad enough to see a stranger.

Funny birds you do see, to be sure, when you have not a gun, as also when you are provided with artillery. What do you think I heard, while taking my diluted holiday, one rustical dweller say to another agricultural gentleman of a third party unknown? I happened on them at the end of an oration in which the story-teller said, in effect, as $\mathrm{Mr}$ Bettinson does at the National Sporting Club: "So-and-so is the winner, gentlemen"; only he meant to say that himself had won-on points and a knock-out, too, I should think, by his style. The part I caught was this: "What did he do then?" asked number two. "Do?" replied t'other; "the 
only thing he could do-'ang 'is 'ead and hexit." A saying which lasted me till I came to another fort by Betchworth Clump, and that very excellent little roadside inn which the noble conqueror cited would have called the 'And in 'And. If, on my recommendation, Refereaders do not look up the little inn from Betchworth, on the South-Eastern; or Dorking, South-Eastern or South Coast ; or Burford Bridge, South Coast Railway stations, and take their fill of the wonderful views from the ridges, and explore the downs at the woodlands, in which they are free to wander at discretion and with discretion, they will have themselves to blame. I never have myself been to blame in this regard, nor for neglecting Headley, Walton-on-the-Hill, Banstead, Nork, or any of those places, when I had an opportunity of looking them up. Some day, perhaps, when a hard frost prevents racing at Epsom Summer Meeting, I may be able to take a turn under rather more favourable conditions than obtained while I was trapesing round last week, making the best of my holiday in the mire-mire I write-but, bless you, thawing ploughed fields are nothing to cross when you are used to them, unless you are conscientiously worried about taking the proprietor's freehold away on your boots. Towards the end of the day, as the ground became more and more giving, it came to be quite enjoyable, so easy it was to the feet, though the railway officials did not seem to be fond of my custom when I wanted to take a lift for two or three miles to rest my faithful long-haired dog, who will never interfere with a fellow-passenger so long as he has a comfortable seat. Perhaps they recognised the 
bushel or so of land, and thought we had stolen the same; "lifted" we certainly had.

Once upon a time I spent many hours reading the Derby's conditions through from its initiation to-well, I forget how far I carried the quest, but I know I got jolly well tired of the job, and, thanks to the dust off the old volumes of the Racing Calendar consulted, I contracted an irritation of the nose forty times worse than any hay fever. The Derby began as a biennial or triennial, and has been chopped and changed about very much over and over again. As to its course and the distance, some of us about now can remember two or three variations. Before my time the start was out of sight from the present stand; but perhaps in view of the ancient betting ring, which, so far as I can make out, was on the high ground about where the mile races start now. The horses came from a point behind the cottage marked on ancient maps as Sir Gilbert Heathcote's, and the track was a lot better than the present one, because the hill to climb was less severe and the field edged far more gradually to the bend, leaving the Craven post well to the left. When most of us first remember the Derby the starting-place was a good bit nearer the stand than it is now, and competitors were set a very stiff climb indeed from the fall of the flag. The trouble with $\mathrm{Mr}$ Studd, who, as Lord of the Manor of Walton, had the temerity to want a share of the money earned by racing over his territory, was, I believe, responsible for some alteration-or was such only schemed out for an alternative course? But that does not matter, I only wanted to show that when one talks of a St Leger or Derby time, comparing it with another, there may be penalties in differ- 
ences of plan and allowances for variations of distance to trim the measurements taken off-hand as identical, not to mention weights differing from period to period.

People in general are much too apt to assume that because it is winter, you cannot take an enjoyable and pretty walk. You find out what a fallacy that is if you want to take walks and have to take them jolly well when you get a chance, which chance seems, to a racing man, to be frequently given on the same principle as the commons were left common-because they seemed no good for anything. Take my walks abroad at these unvalued periods I must, seeing what a creature of circumstances my trades, occupations, and professions (I seem to have about as many as a bundle of them) render me, and, so far as in me lies, make the best of things as they "fall," missing no opportunity of washing the slate clean with due gratitude, a little superior to the lively sense of favours to come, for all the pleasure one can extract from them.

Fairly dry weather in December, even when things are not slicked up by frost, offers wholesome and suitable conditions enough for getting about. Certainly you miss the little touch of tingly frost, so stimulating and precious to the well-clothed, and at the same time health-giving; but in winter, you know, a sort of compensating thermometer is always before the pitiful man's eyes. His imagination sees with each falling degree the going up of increasingly sore times for the hard-up. Open weather does mean such a lot. In it most trades can be carried on without interruption, ensuring continuous supply for the needy worker. 
Cows in the meadows and horses turned out do, as every child knows, keep Sunday. I do not mean horses which are given a run in the fields on the day that comes betwixt the Saturday and Monday - they ought to know - but gees having a spell of long rest, or lucky ones with all their working troubles to come and no record of labour so far. Do the little dicky birds and the big, the undomesticated who live on their own-can they tell when Christmas comes once a year? The robin of the picture should be able to spot the date and be pleased with it, because he is always (in them) being treated to about enough to make too much for twenty birds ten times his size. My word! that means a lot too, as you would find out if an old man redbreast selected you for purveyor and insisted upon being fed at all hours during the day, with quick lunches going perpetually between the meals. If the birds of the air are informed in the matter of the seasons other than by Nature's calendarthe coming and going of the fruits of the earth, the cold and warmth-I guess the very one they do most dislike is old-fashioned Christmas winter. And so do I, for their sakes. Seeing the poor little bodies puffed out with cold, being starved and clemmed when human attention is dwelling quite sufficiently on plentiful eating and drinking, makes you feel that there is something wrong. We are not half so bad as we used to be, thanks in great measure to the gun licensing being so well looked after, and one seldom now sees hobbledehoys blowing to pieces little, little songsters, as easy to hit as a winter cabbage.

I took particular notice of the birds at Christmas as I perambulated round about in a sort of 
semicircle with a diameter drawn from Ripley to Leatherhead. Finely varied country this, its borders trenching on the devious flow of the Mole, a river rendered harder and harder of access by reason of a gradual progress in shutting up old footpaths and rights of way. A funny chap is this Mole, well-named, as Refereaders are aware, because of his burrowing habits and hidings in sinks or swallows, subterranean hollows accounting for a bed, dry superficially, with running water on each side. Each side, I say, not on each edge. No other river in the South of England so quickly gets into flood or empties itself to normal level-if the Thames will allow it. Occasionally, you know, the Mole cannot get out at Molesey, because the big river shuts the other's mouth up and does serious damage, otherwise a comparison of the two streams' goings on in the neighbourhood of the Mole's outlet can be quite comical.

To get away from our birds for a bit, Ripley, a very slightly altered typical Surrey village, is, I think, looking up again a little, but the motors have driven off very much of the cyclists' custom and stopped nearly all the walkers who like to take their tikes with them. There are two things impossible to do with satisfaction to yourself and other people. One is to back your horses at S.P. and go on to the course without being fixed up between giving your business away and giving other people away. The just-mentioned walking with your dogs on a motory road or by the side of it, is another, if you are going to get pleasure out of it. Thank goodness, we have yet to experience the dog-followed motor. I should very much like to see it once, and have the dog 
myself that could worry along, as some owners used to make their tikes come on long journeys after a bicycle. In general, dogs and cycles do not go together. The faithful animal never has quite taken to cycles-I do not mean as a rider -except to his master's, and a lot of him were and are pests seeking, of malice prepense, to cause an accident. Unhappily, too, their tendency to interfere with a wheeler's indisputable right to the road was frequently fostered by proprietors. Not so much was I thinking of this sort as of an artful section who, confident in their judgment of pace and so forth, would deliberately lay themselves out-dogs, not their masters-to spoof the wheel-rider and involve him in entanglements. Canines I have known who could play out of their heads all the tricks the nervous old lady will involuntarily illustrate, offering and retreating, stopping when she shouldn't and going on when she didn't ought, in making passage from one kerbstone of a busy road to that opposite. One gentleman in particular I recollect who regarded every cyclist's bell as a warning requiring him to cross the ringer's course, get himself as nearly as possible but not quite run over, and give the unhappy wheelman every chance of coming to grief. Not once but hundreds of times in a year would he play this trick; and the worst of it was you dare not say a word to him, because if he did answer your signals from the bank-I should say road-edge-he would make an outward tack before coming back on another hoard, so by interference you only turned bad into worse. The sensible course was to pretend that you did not know anything about him, he was no dog of yours, more especially 
should catastrophe arrive, and, like the pair in "Struwwelpeter," boy or man and doggie come bump, thump, in a lump. I never knew the lastnamed hurt himself; in fact, he was always ready to render first aid, either by barking at his brother in misfortune or by licking his face, both processes irritating, I am told. That this eccentric character died in his own bed, so to speak, sufficiently explained that in his little games he was able to discriminate between cycles and motors. One application of these latter is too apt to act like the celebrated soothing syrup with trade mark, "Baby never cries after one dose."

One beauty of our Christmas holiday weather at the time I am talking of, lay in its being not too wet nor yet too dry, only just beautifully middling for the roads. They were really perfect for walking, too dry for mud, too damp for dust, and neither sticky nor slippery. The big tyres ran well on the going, and the fancy varieties, capable of putting it into as gritty state as could a flock of sheep, by grinding out and lifting up the small particles of the macadam, left no trace of their handiwork. Not one motor did I see scorching; 'cause why, I may be asked; I know the "because" very well, but am rather willing to believe in a better motive than fear of (police) consequences. As to those who only did not go faster because they did not dare, they and I differ in perception actual and moral. Leaving the latter out of the question as debatable matter leading possibly to unfriendly discussion and therefore unseasonable, I cannot see the pleasure of going at a high speed past or through country worth looking at. Perhaps, with better practice, 
I could educate my vision so as to take in the objects of interest that make so much amusement for me. Try as I will, I seem to miss an awful lot progressing at the rate of a mile in three minutes; but, then, I dare say a very great many do not care a tinker's cuss for the small beer and small potatoes in beast, bird, vegetable, insect, and reptile life.

I had one turn at high speed. We only did nineteen miles in eleven minutes downhill on a narrow road and a Bank Holiday, and I fear I discredited the cloth in describing my sensations to the kindly chauffeur-host who took me out to give me a treat. He asked how I felt. Really I meant no offence in likening myself, and by consequence him-I had forgotten that-to a member of the herd of swine rushing violently down a steep place, with acute preference for going into the sea if we went into anything. In the sea you might have a chance by swimming, but otherwise touching meant going.

Cannot something be done to alter the system of carriage illumination? I will not describe the up-to-date lamplight as too brilliant-scarcely can that pitch of intensity be reached. Theoretically and practically, no light can be too good for distribution. Where the trouble comes is, like the Bunsbyan philosophy, in the application of it. Will not some firm of opticians, lampmakers, inventors, or manufacturers take the job in hand and bring out a lamp to lighten up the road without blinding wayfarers? A splendid creation, to my mind, is a big motor-car, with its cleverly devised appointments, carrying a certain touch of ocean-going trimness and tautness about it, an idea suggested, perhaps, by its lights. By day I 
can stand and admire a swagger machine for a long while at a stretch. After dark that same is a terror to me. This story, scarcely new, is all the same worth re-telling because of the fearful nuisance and danger caused by the very excellence of the means adopted mostly in the cause of safety itself. With one of these monstrouseyed machines coming at you out of the dark you are blinded and paralysed for action. Not only do motors' big lamps act in this way, but the humble cyclist's acetylene lighter-up, if you happen to catch its glare full. All you know is that you think yourself in danger, whether you are so or not, and are pretty much unable to help yourself in getting out of the way, because the fierce white light cuts through the air like a guillotine. Inside the edge of its rays you might be in the limelight. At a line outside is created an artificial darkness that can be felt, and makes unknown territory. Quite unsuccessful are my best endeavours to mend this trouble for myself; the only way is the old-fashioned one for a traveller on a very dark road-viz., getting out of the way when you saw a lighted trap coming (they used not always to be lighted up, you know, till recent Acts), and shutting your eyes till the machine had gone by, so preventing them from getting out of focus. I do wish for someone to experiment with an apron shade to send the bright white rays out ahead along the road instead of straight away into your brain. Under this arrangement the lamps would be twice as efficacious for the drivers' purpose as they are now.

Talking about seeing, those who believe in funny birds cropping up only when you have 
not a gun, do not have all the best of the argument, because a-many fearful fowl and other curiosities are brought down by the gunner. I fixed up two or three curious specimens on Christmas Day. Possibly number one would not be a rarity to gents in one particular fancy line-i.e., donkey keeping and breeding. Dead donkeys are, in accordance with the proverb, seldom on view, though the fact that you can buy all the skins you want at about a dollar apiece proves that somebody must see them sooner or later. The well-groomed moke, as proud of himself as his master is of the creature, is to me a thing of beauty and of joy. I have always coveted some of these, but never attained the distinction of ownership in a willing specimen. Now, what do you think I came across in the way of donkeys? A nice little fellow, welldone, fat and sleek, and with string halt in front, pretty near as pronounced as Memoir's. I have heard dealers, in praising a horse's high action, chaffingly liken it to string halt all round. This one had it in front, and very rum he looked. In another strange discovery I was rather the discoveree than the discoverer, for only by decimals of inches did I miss being discovered in the back by a cyclist's tyre, he, his partner in bad watermanship on the road, and myself all being within about a yard of the off-edge of the road. They were a mile out of Leatherhead, not going above fifteen miles an hour, so were, they stated, perfectly justified in not ringing the bell till they were in touch of me. Nowadays you expect even holiday cyclists to know the near side of the road from the off without tying a hayband on one wrist and a straw-band on the other. 
These young parties declined to discuss the rule of the road, but pitched into me because I had crossed a little while before we got mixed up. In the matter of logic they were triumphantly unassailable. How can you controvert the assertion, "If you had stopped over there you would not have been here."

I saw a funny bird who had views on the rights of the road, practically to the effect that it didn't mind how much of it it took. When I came across this masterful man he was playing wolf to the lamb of a little boy carrying a burden in the very place where he ought to be, the extreme right edge of the footpath ; t'other party, an equestrian, had a led horse, and all the road to himself. Very properly, as I understand the rules, he took the second steed on his off-side so as to be between it and advancing traffic, while nothing coming behind should cause disturbance. With the great highway all his, pro tem., his line was right on the path's coping. Instead of which, he blew the poor little nipper up sky-high and said horse-kicking would serve him right. This notion set me thinking whether conventional handling of led horses is quite as commonsensible as it might be, where the road is bordered by paths. The question is, you know, whether an obstreperous led animal should chance kicking traps and other horses or human beings. A lot of points must be taken into consideration when the Imperial rules of the road are drawn up. They do not exist at present, I believe. While such rates are being drafted I hope pronouncement will be made to guide the pedestrian using the road. According to some, he should rank himself as a vehicle, seeing that 
he consorts with such, and so steer to the left. More is, I think, to be said for his taking the right edge while he uses the track as a footpath. On the latter course he should be quite safe from anything coming the way that he is going, and with a proper lookout, can make his own arrangements to accommodate himself with what meets his advance.

One more funny bird. I came on a dismounted steeplechase rider hanging on to the end of his reins while he, up a steep bank, was endeavouring to keep his horse in hold and reach some privet berries. "For the bullfinch at home," says he, so we took a department eachhe minded the horse and I harvested the little black fruit. Here is where the funny part comes in. Up to then I had not seen a single bully, who is a very attention-attracting chap, because of the brilliant white he shows in flying. I give you my word that going back on my tracks I seemed scarcely ever free from bullfinches. They were for ever zig-zagging across from hedge to hedge, or flitting along them, and seemed almost as plentiful as robins. That bold customer is to be found wherever anything to eat is going. You may not hit on one all day till you pull out food; so doing, you call him up from the vasty deep. So no one with a bit of bread, and cheese for preference, need ever be without a robin's company. 


\section{CHAPTER XIII}

\section{NEWMARKET}

Newmarket, you know, is the Metropolis of the Turf, and all other centres quite countrified. Outside racing matters, the little town places itself, I believe, second to London, with Yarmouth third. Of Newmarket I am very fond, as anyone must be who knows the place and is able to get about. Its air, water, and Mr Musks's mutton are almost unapproachable, in combination for hygienic purposes. I have wondered if a sort of balance to racing's fortunes might not be found in exploiting Newmarket as a health resort. Testimonials by the tens of thousands are always available from frequenters, or merely occasional visitors; who mostly, in spite of setting quite the wrong way to work, do reap great benefits from passing a few days between the Heath's remainders as cut up for civilisation's requirements. How do most of us go while doing a meeting? What percentage of the racing army gets its pennyworth out of the grand, strong air a-mornings, or then takes exercise enough? A precious small one, as you must know, if you patrol the roads within a quite moderate radius of the late $\mathrm{Mr}$ Blanton's clock 
and its tower. Do we lead a country life, rising betimes, and retiring to roost correspondingly early ; or is the custom in this part of the country to lengthen the days by taking a bit out of the night, boys! The lot of us on the average set Newmarket's grand air, grand water, and fine meat an unfair trial-viz., to keep us from going back instead of "keeping" as we ought, to use the North-country word. In brief, the practice is to ask to be done up, and work towards that end; and yet, thanks to beneficial surroundings and accessories, you mostly come out with a balance to the good in hand. If such desirable results can be and are achieved under severe handicapping, what price Newmarket for health resorters honestly bent on turning its good gifts -among which I number the mutton, especially the mutton, and the clean grown vegetables-to best account. Please understand me to be keeping out of view making our Newmarket a sanatorium or cure centre, which always must carry a lot of depression with it as the proportion of invalids to the sound, or, at any rate, the active service hands is increased beyond normal proportions. I simply ask what price Newmarket as a desirable residential district for folk to come and enjoy life in, building themselves up the while? Half the people sent to be braced up at the seaside are at the wrong place when they get there, because the sea air and their livers cannot rub on together. For these inland, with quite as strong air, but none of the blinky, owly, sluggish sleepiness affecting certain constitutions while on the coast, works like a charm. If you go to Newmarket, ask for restoration, and do not get it, you must be very unlucky. Any- 
way, there is recommendation for households who frequently find members in need of setting up, and I suppose the equivalent for half a brick on the head at my service for dreaming of a Newmarket quarter not altogether for Newmarket racing and training.

Perhaps the half might be reduced to say a brickbat, on my mentioning as one of the charms of the said sanatorium the interest the patients might get out of the training. Newmarket to the person not concerned in expense, yet interested in horses, stands by itself as offering free every day, unless weather interrupts, a moving panorama of the life of the high-metalled racer, leaving out (though perchance you might find it, if you care or can bear to look for it) the last scenes in that eventful history as painfully depicted in the old series of prints once so popular. From the mighty stud-horse taking his walks abroad, and, contrary to general idea, a marvel of well-bred docility, with frequently strong affection for his companion and attendant, to the little foal gambolling at its mother's feet, tottery on legs, which have had only a few hours' practice, you can see the whole seven ages of the thoroughbred. The two mentioned you must seek in their proper places, but the older youngsters being lunged, those broken to work at exercise, strings of horses representing thousands and thousands of pounds, cantering and practicegalloping, with, almost every day in the season, trials, undress rehearsals of hard races, are at the onlooker's service.

To many the actual racing ranks in attraction but little before the operations of raising and educating which appeal so strongly to lovers of 
horses. And, seeing how great a proportion of those who find the money to make Newmarket to go miss being sufficiently in their horses' society to become even their acquaintances, let alone friends, I do often greatly marvel that the little town does so well, while, at the same time, feeling sorry for the sportsmen who have the means to keep up a stud, but not the time to draw from it consideration that comes from being in close touch with your animals. These are almost in the same position as the proprietor of dogs kept by an agent for show, as compared with one who makes his tikes companions on a basis of mutual esteem and understanding. The next best thing to having all you want is to take what you can get, and be content as you can; but lucky indeed is the proprietor who has his stock grow up under his eyes, and can follow their education, development, and training in detail—a fascinating operation, more especially when you have personal interest in the creatures. To not a few these pleasures are denied, and for all friendly relation there is between them and their horses, the latter might almost as well be mere machines. Of course there are times when every stable's affairs go wrong, and, so to speak, living in it means having its troubles always before you. Still, the same sort of thing occurs to an extent under the other arrangements, where the pleasures indicated for make-weights are lacking.

Undoubtedly the owner who breeds his own stock and has training grounds also within handy distance of his residence, must get a very great deal more for his money than do the less fortunate, who must make excursions to and appear at 
their raising or training studs as visitors rather than residents. I can conceive nothing more charming than the position of the former species of owner, who, among his stud matrons, sires, and their progeny of various ages, is as was the oldfashioned squire on his estates and in the village we will suppose adjacent, and pretty much his property, where he knows every man Jack of 'em, also Dick, Tom, and Harry, with Jill and the rest to match, their histories and forbears, their occupations, prospects, joys, and troubles, and has no small hand in making the world go well for all. Births, deaths, and marriages in his stud are on a par with like news among the villagers. The foals are the babies, the yearlings the little children, the two-year-olds the "growing" boys and girls, lads and lassies, and the three-year-olds, the come-of-age men and women, as are the elders, to be located among the other's lot-ages with, at every stage, the real head of the stable's eye and heart on them, as part of his own establishment. Here comes in sentiment which should keep sport at its strongest. The other sort more mature humans have to take on the principle of eating crust if you can't get crumb, but is nothing like so enjoyable, though, of course, for many busy owners, the only kind to be had.

A treat I always prize greatly, is doing a stud farm and training stable in leisurely fashion, without any obligation to go through the stables or the paddocks beyond taking general observations. In March of 1905 I made a pilgrimage through the geographical district known as Choke Jade, to renew acquaintance with my old friend Moifaa, whose appearance, I was informed, had 
been strangely altered. Going by the quidnuncs' stories, I might not have been surprised to see the noble steed's long-visaged napper thrown into greater prominence than ever by having his mane hogged, while as for his tail-well, you know the pictures of the old-fashioned hunter with a short dock, suggesting that a dog-fancier had done it with his teeth-and a three-cornered remains of a caudal appendage, about as useless as it was inelegant, and almost a replica of a trimmed fighting-cock's. You are familiar with such animal sketches, of which early proofs are turned out every week by the thousand-date and all, while you wait. So you know what sort of apparition I was prepared to be startled by, say, the big bony Colonial all Elgin marble elegance in the bows, and Tom-and-Jerry trimmed aft. His manners, too, had been disparaged, and much made of his invincible predilection for going off to the left, and altogether I felt I might be on the line of an abortional phenomenon. "Instead of which," there was old Moifaa, with his honest, unbeautiful face, just the same powerful chap as ever, brightened up on his coat, certainly, with a nice mane, and his tail-long flowing tail-no more cut off, as they said, than was your beard, my good reader, when you went to the hairdresser to have the points taken off so as to spruce you up a little.

Between Moifaa in his old stable at Epsom and Moifaa at Egerton House, Newmarket, is much the same difference as with any of us in working trim and got-up a little for an occasion - no more for sure. He never looked better so long as I have known him, nor could he have moved better. His peculiarity of hanging to the 
left in jumping is well known, but a more tactable chap in ordinary exercise could not be made to order. The boy who walked him off to the stables after John Watts had been on his back in a canter may have weighed fifty pounds, but I think I should rather bet that he did not go four stone than wager the other way. This tiny mite and the big horse got on together admirably. Among the string Mr Marsh had out were some two-year-olds calculated to take anyone's fancy, and tried performers whose records can be read in the Calendar. They and their work made one chapter in a delightful volume. The well-drilled army of retainers, units in the great machinery of the vast establishment, could furnish another, with system and consequent economy of time and labour always accentuating themselves on your observation. The parade on the home walking ground before making for the Heath gave another charming scene, but the prettiest of all was to see the stud matrons with their babies-some little leggy things only a few days old, and as pretty in their ways as fawns, with the old ladies' eyes always on them. One very distinguished lady I came across looking as sober and demure as if she had never known what excitement speltstill, a very observant party all the same, taking interest in everything going on within her view. This was Sceptre, one of the greatest popular idols of any age, and I should not like to say how good at her best. If anyone could have such things as racing establishments for playthings, as do children toys, and I were given only one choice, I think someone else would have to decide for me between a farmyard and a trainerbreeder's household. I rather fancy best the 
homestead and stockyard, with a peacock on the wall, pigs and piglings, draught-horses and kine, a gobbling turkey-cock, and a gamecock crowing to his ladies, and in defiance of the other fellow over the way; ducks waddling in procession, martins working from under the eaves, a shepherd and his dog coming about their business, hinds and, of course, a milkmaid, going about theirs ; all the stock sleek and well-fed; the old hunter poking his nose out over his box's half-door, the granary cat sunning herself on the wall, the rooks building in the high elm, a thrush conversing on the highest perch obtainable, and the pigeons slithering over the moss-grown tile roof. That is the sort of toy I should best like, marked with prosperity stamped on each article; but perhaps I could make this dead-heat with the well-ordered training establishment when things go well.

Mind, I am only talking of toys; I might talk of such possessions literally and seriously, and have as much chance of getting one as the other, except as an unendowed spectator, in which capacity paying my visit to Moifaa placed me, an unrecognised proprietor pro tem., without any liability as to the up-keep or responsibility other than coming and departing in peace. Still, if you can, be friends with plenty of people too rich and grand for you to live in the same house with. I mention, among many, a couple of settled-down old married gentlemen, well-to-do, very well to do -indeed, too swagger in their style of living for the likes of me to keep up with, but still careful of their precious healths to the extent of taking a strong constitutional every morning, and for all I know, of an afternoon too. Often I set out in their direction, Cheveley, on purpose to have the 
pleasure of passing the time of day with them and a couple of attendants whom they take about for company. A couple of fine old swells these retired sportsmen, $\mathrm{Mr}$ Suspender and $\mathrm{Mr}$ Isinglass. Mostly they toddled down from Cheveley to Newmarket to fetch the papers, going by the Duchess's drive and coming back by the Ashley road. Better pals than they and their attendants you could not desire, nor men prouder of their charges-proud as the cocky pheasants who hereabouts abound in marvellous foliage, as the gardener said of the other thing, and by the thousand too.

Our owners, trainers, and others at Newmarket, holders of houses or stables interesting to the public, might confer a great boon on strangers by labelling their establishments legibly. Tens of thousands pass in and out of the little town in the course of a few years, and most of them depart no wiser in local topography than when they first set foot in the place. Certainly a house is the Englishman's castle, private to the proprietor if anything can be, and good folk do hate advertising themselves; so objection on the latter score might easily be considered as fatal to the idea of cataloguing places. At the same time, so marking them off need do no harm, and must be of great service to the uninitiated who seek to localise establishments of which they read and hear so much. They do want to see for themselves where this, that, and the other bygone swell performer was housed while in training, and are still more curious concerning current celebrities. Also is wanted a cheap map of the Heath. The only one I know would be dear at the price if it served for, say, the United Kingdom, with 
Greater Britain delineated and chucked in. May not somebody bring out a popular chart at popular price for folk to consult while on the spot, and take home for future reference? Here is opportunity for satisfying a long-felt want. The cost of production would be slight, and surely a constant sale be assured--if the price was right.

Half Newmarket knows very little of its own surroundings, and it is precious little denizens in the "parts about" can tell you of villages only a little way off, comparatively speaking, and that though the labourers are a quick-walking race, thanks to two fine sports, poaching and skating. Some readers, I daresay, have been in and admired Icklingham, a typical long Suffolk village -flint, brick, mud, plaster, and thatch-built principally, with here and there a good house, everybody apparently well-to-do, and the elder women-the men do not show it-bearing the Fen mark, the darkness under the skin which used to go with intermittent fevers and agues. Hereabouts is a tract of miserably poor scrub-land inhabited by rabbits, who eat all its flesh, which is grass and the heather, down to the bone, and polish up the remains so close that on a hot day you can't walk because the surface of the vegetation left over the sandy soil is like a slide. You may meet someone, again you may not, most likely not, as you range about an object of curiosity to the wheatears, whose brilliant white skirts make them a mark as far as the eye can carry as they skim about. Near the river, which makes a wedge of fen in the sandy waste, sandpipers breed and greet your advance with whistles in their own singular minor key. Just a few thrushes lope about, and I had the pleasure of a 
blundering old stupid of a yofful's society for quite a considerable time. Wood-pigeons' powers of flight are so great that they are bound to occur anywhere, everywhere, and with them were bigger, owl-coloured birds I could not earmark, because of the sun's great glare. Green plovers were few, imitating their relations, the sandpipers, by running instead of wheeling on the wing, complaining about being disturbed, and compelling attention which need not be pointed at them at all.

On the waste's edge big trees made an olive setting to a picture quivering in the heat haze and of remarkable tone, because of the face of the land being coloured by pinky purple patches of a starveling sorrel, studded with bosses of dark sprouting heather almost flat to the ground, a glow that made you look up at the sun and wonder what he was doing over the yardarm instead of dropping in glory over the western horizon. No artist who put the tint on canvas would be believed if he dated and time-o-day'd his picture, but there it was at your service all for you, and the birds and the rabbits, who were "brusselling" very industriously. The scene seemed incomplete without a big hawk on the watch, but was short of that accessary all the same, so his natural prey went about on business free enough to annoy a poor chap like myself, who, though confessing himself a fool, hates to be called one, and a malevolent imbecile at that. What annoys me about the tricks played on your humble servant is the assumption that little bird babies would not be safe with me, and that since I go about seeking whom I may wantonly maim and destroy, so must I be humbugged. 
I might have been all the monsters of history, from Herod and the ogres of fairyland to the unamiable uncle of the Princes in the Tower, to judge by the way I was treated. The confounded peewits were quite certain I was after their little balls of fluff, and played all sorts of shallow tricks to take me away from the shelter under a bank's edge where "the babies" would be clustering up "still as a mouse." "Same here" it was with the wheatears, who offered to take me for a walk and show me something I should very much like to have, or some tale like that. Let 'em keep their youngsters. Surely if I desired to commit bird slaughter I should go for the grown-up creature toddling along almost within stick stroke, instead of searching for immature nestlings coloured to match their habitat and its fittings. Then the sandpipers. Was it likely I could be whistled and wheedled to "come-along-o'-me" sort of wanderings just because they pantomimically declared that I had better forsake my route and meander away into the bush, goodness knows where? Partridges were playing much the same game last time I was at Newmarket. Nobody seems to leave me alone. Even the wrens came out of the reeds by the Lark and scolded and fussed. A wren would be a chatter-mag in church or while being presented at Court-it is their nature to. And the benighted great woodpecker, who wants to hank his little lot out of a hole? What call had he to follow me up from tree to tree, always sitting on the next, keeping still and quiet till I passed and then going ahead again, with his ewe neck making him look as if he would fall in half, to roost and restart so long as the old Scotches lasted-rather a bibulous flavour that 
has. They were somewhat scraggy and battered in battles with gales-all the winds of heaven have free run over Icklingham's waste, scrub, heath, common, or what you please to style it; but in the sun-and it was sun, too-the wind was heated till it almost bit, and you expected to hear vegetation crackle like fir-cones and furze-pods bursting.

In the sun these elderly firs gave off resinous aroma, making an air pine-bath from their "medicinal gums"-_bress 'em!- -joyful to dwell in and fill your lungs with. A big, long day I could have spent in their company, or a little further on where giant aspens rustled soothingly and sleepily as might any waterfall, and a few steps beyond them the Lark comes to a lock and sluice, which might have sat for Constable's Flatford Lock on the Stour. Here, before you actually get to Icklingham, is a bridge with rails of exactly the right height to lean upon, not too high nor too low, but, as was the bear's chair, exactly a fit; and good playfellows too, among the willows and sedges, the great trusses of purple loose-strife, and waves of scented meadow-sweet, with a tall lime, a vast hive for the bees using up the blossoms and the honey-dew, and more amusing company in the clear clean water, where dace and roach-big chaps some-skirmished in shoals, droves of fifty and more, nice sizeable fish for those who want to catch them-I do not.

What a power of quiet, peaceful thinking a body can do looking down on green leaves and moving water, and how disturbing to orderly soothing meditation it is to have a forty-humming-bird power vivid, lurid blue kingfisher streak like straight lightning through a bridge's dark 
shadow at the moment when you are half persuading yourself that the monster, a live green-backed fat fish, who, making no apparent exercise of motive power, sleepily glides through the gloom of the arch's shelter from the light for a moment into view is the ghost of the King of the Carp having his day out. Ghost he must be, for surely no chap of that size could be alive and not sought to his destruction; if only of fisherman's, not avoirdupois, weight, he is a whopper; and, seen through your half-closed eyes, he might weigh a ton. The kingfisher's doing away with dreamy estimates and breaking up the party was, perhaps, as well, for the trudge back to headquarters is long, refreshments scarce, and stops to investigate odds and ends many. Such as the keeper's cemetery, started with a jackdaw and half-a-dozen squirrels ; a mavis's nest low down in a willow's trunk, made of bent to match the tree's own stringy growth from the crown of its pollarding ; a stoat, sitting up for all the world like a cobra about to strike; an old gentleman of my acquaintance, with a half-gallon thirst after mowing a rough meadow down by the little river that crosses the Thetford road handy to the Red Lodge (good entertainment for man and beast there), and others sure to be responsible for detours and excursions that eat up time. Talking about excursions, I hope I have not been wandering at all, for if there is one thing on which I pride myself it is sticking to my text. In effect I begin with the cognac, I finish the cognac. I never mix - but what price Newmarket, this style, as a health-giver? 


\section{CHAPTER XIV}

\section{NEWMARKET REMINISCENCES}

How long ago is it since, by an act altogether unjustifiable legally, so say the Newmarket protestants, the Red Post was moved? Now anger has subsided and sorrow supervened, I can forgive but never shall forget the crime-a sort of licensed body-snatching. With Jockey Club's rights and Newmarket town's privileges, alienation of property, or conservation thereof, maintenance or denial of claim to free use and passage on the Heath for the general public or locally qualified, and destruction of these assets, I have nothing to say just now, except that, as a rule, big people's improvements such as have led to a considerable bobbery in and about the little town, almost invariably end in exclusiveness, as regards possession, being extended for the great to the little ones' cost. My concern is not with alleged extinguishing of metalled roads and footpaths, or enclosures where all was open; not even with the blotting out of a largish area from the Top of the Town to the Turn of the Lands as a raceground dedicated to the Newmarket people. Much grievance has been felt and expressed on these several heads, and I am glad to find some being relieved. Mine is not a protest with solely 
material foundation, but, oh! Mr Marryott, you acting for the St:wards, Directors of the Jockey Club, did give sentiment a very nasty body-blow and landed in a most tender place.

How could you go for to do so, Mr M., and yourself as prime mover, or merely active accessory, in the fact, 'take away the Red Post, or allow anyone else to lay hands on that sacred bit of timber? Rather should I have pictured authority's representative leading a choral service, assuring the ancient race mark of a kind of filial reverence, attachment, and defiance to all and sundry threatening it with damage, not to mention tearing it up by its ancient roots, and casting the relic away to be stuck up in a stableyard. Has not the Jockey Club ever read, said, or sung anyone of it, "Woodman, Spare that Tree!" Surely a version adapted to the object and occasion must have suggested itself to many old parties when they heard, too late, of this terrible act of vandalism. Some years ago, when moving off this object of interest in the neighbourhood was half, only half, hinted at, a shudder spread from the centre of information through the racing world's constitution as ripples decentralise in a pond from the splash of a stone. Several then put in pleas for the woodman of the Heath to spare that bit of a tree, associated with so many stirring events to be remembered in the history of English sport, mostly in Criterions and Cambridgeshires. If I remember right, myself, I treated the rumour as a very savage canard indeed, and rated the story's materialisation as an absurdity only to be equalled by the idea of the Stewards selling the Bushes to warm bakers' ovens. 
Alas! we live and learn, and the object of admiration, the material fetish, which people who are not superstitious, yet liked to do as others did, could lovingly pat, on their way down to the Rowley Mile, in case that process could bring them luck ; the point in Cambridgeshire "descriptions" so conveniently situated as was the Shepherd's track, to gain which was supposed to give its possessor such advantage; the somewhat decayed but still sturdy post, so easily turned out respectable at the cost of a coat or two of paint to repair the ravages of weather on its complexion, has gone. That it will be cherished by $\mathrm{Mr}$ Felix Leach, who has got sentiment in his system, while its late guardians that ought to have been have not, is a comfort. But what a dreadful thing for us, who look up to the Jockey Club, many of whom have spent-well thousands is not too much to say-in collecting racing relics, such as pictures and cups, and find them without sentiment enough to keep to themselves a memorial really an integral part of the great Heath and its traditions. I do not drop into poetry, that being an unconsidered extra, at first or second hand. Let those who wish a little in that line overhaul their Peter Bell and note how handy for adaptation his primrose comes in with the poor old Red Post on the course's brim. And "a bit of timber 'twas to him," the custodian, or them-the Jockey Club- "and it was nothing more."

Personally, I am not so altogether surprised at this manifestation of the policy of immediate convenience as against looking on things with what, for want of a better word, I have called sentiment. Some years ago I thought to requite 
kindness shown me by a Colonial Jockey Club. I offered to send them out-free, of course, of all expenses-a very historical starting-post, and expected to receive a reply urging me to make sure of getting the article packed up and on board ship as soon as possible. How I was to come by the article I will not say here, except that a friend in office was to be judiciously oblivious of what was going to be done, and that the scheme for this household word's removal on a dark, moonless night was all laid out. Mind, it was to be treated with every proper respect, and, after its emigration, set up in a place of great honour, to make a link carrying racing men's thoughts many thousand miles across the seas to the Old Country, and in the new land of ours keep green memories of mighty horses who had run in the greatest of all our contests from a date not less than a century old. "Instead of which," the reply was that, in effect, all concerned did not care the price of firewood about the post, being, in short, the lot of them, just so many Colonial Peter Bells.

Seriously, I do think that as regards the Red Post or a similar monument, remains, or trophy, the Powers might have felt for it more proprietorial respect than to allow of its being presented to, or appropriated by, any individual ; and I am quite certain that wiping out the sentimental side-which, mark you, includes a good deal of the enthusiasm that should form the basis of true sport-is a mistake. We do not want, it is not good for pastime's estate, to have everything measured by a pounds, shillings, and pence standard, or disposed so that directly its value for active purposes passes it shall be in 
effect bundled off to the marine store dealer-by which, Mr Leach, please understand I ain't aaiming at you. We are hurried quite enough already, so that history made one day is forgotten the next-almost as if its events had never beenand simple little matters like the Cambridgeshire's Red Post-late our western boundary of the flat galloping to the finish, now abolished-do, I believe, have their valuable uses as reminders of old times and old timers-man and horse. I always was very sorry when another high-coloured adjunct to racing disappeared, and with him his office. Old Martin Starling, in his scarlet coat, a. shade or two paler than his rubicund old crusted complexion, was a fine figure of a man on a horse (grey for choice) as an active and visible Master of the Ceremonies, conducting the competitors to the start, aiding with his long whip in clearing the course, and, in my opinion, in type a requisite functionary to take charge of the winning horse and personally conduct it and its rider to the weighing-in place.

You cannot now make a picture of a racecourse scene- "Returning to Scale"-without one thing being lacking to those who recollect the old régime. For giving local colouring to the track, old Martin Starling (I knew him and his son Martin, too- $t$ two of tie only five Martins I recollect being on the Turf) was worth all his money in the last capacity, shepherding the winners, and I should be very glad to see his office revived. Had he-that is to say, his successor-been on duty in these later days, we should have missed unpleasantnesses, disqualifications of horses who had fairly won their races, and then lost them, owing to their riders dis- 
mounting before they should. On disqualification for technical irregularities I hold very strong opinions indeed, as Refereaders are aware. Of course one desires that wrongdoers should suffer for their faults, but too often these mistakes do not hit those intimately concerned so hard as the public, and, bearing that in mind, I am all for hedging round actors in the great game with precautions against their falling into error. That is why I have so long fought for a better system of examining entries, to guard against technical objections, and why also I consider that a competent official to take charge of the winning jockey and personally conduct him to the Clerk of the Scales is a necessity. This was amply proved at Leicester when a boy who won was told by a bystander that he was beaten, and so induced to get off before reaching the right place for the purpose.

The editor of the Sporting World astonished me once by advising the Jockey Club to turn Newmarket's into gate-money meetings. I can't see where the Club can do itself any good by declaring the Heath, which is crossed by several rights-of-way, a close borough altogether, and I would be sorry indeed to find them make such a move. In the first place, the crop they would get must be the same as the old lady's when she sheared her pigs-much cry and little wool-for those outside at Newmarket's meetings are not at all likely to pay to go in, seeing that they can't find the money; and, again, the Club would be cutting away the last remnant of the old, almost feudal idea of racingthat the big were not unwishful to provide sport for the small folk. Oh, Mr Sporting World, 
fancy capping the stable-boys and the brokendown old sportsmen-once celebrities, maybewho go so far towards making up the crowd "over the way" at Newmaket! Only think what you are councilling the Club to do, and if your kind heart does not make you sorry you spoke, I am a Dutchman of the Cape brand. Just you run through the list of has-beens whom you know personally, and think to yourself what you might have done for those who cannot now afford to pay to see the game played at which they were once proficient, and who will be brokenhearted if obliged to stay away, thanks to the bar you talked of putting up.

If you ask me how the Club might ensure a better revenue, I should say by reducing their fees rather than by sticking them on, and by inducing the Great Eastern Railway Company to accelerate their service. If the old line-from Chesterford to Six-Mile Bottom, I believe it was-was in existence now, and specials run to do the journey in an hour and a bit-not as big a bit as the hour-and the fines on the course were lowered, the turnover must be much greater. At least, so I believe, and I know that Kitty, which her proper name is Exes, is killing racing for many, at any rate, knocking out half the regulars. Most of the charges are unreasonably dear.

The Newmarket Ditch, locally known as Choke Jade, on the edge of the Cesarewitch course cuts across the opening cleared in the great artificial earthwork and rampart, which may be a Fosse cum vallum of Roman origin or due to their predecessors, for military purposes of defence and offence, the Devil's dodges or 
caprices, or created in other ways. Only one of these alleged explanations of its making is, I hold, not acceptable--viz., that golf flourished in a period far more ancient than any Royal Society dreamed of in connection with the game, and there being giants in the land, the Ditch was planned and executed for a bunker suitable to the clubs and clubbists of the period. Anyway, a bit more of the long-lined mound is being removed, and the corresponding section of dugout trench filled up so as to clear off some of the corner which interferes with the easy progress of horses started on the far side of the Jockey Club's holding, and I should guess that the track will be improved in consequence. What antiquarian societies will say, goodness only knows. Perhaps they had better hold their peace, for the club is autocratic, and protestants can easily be turned into martyrs, especially where graves are, so to speak, already dug waiting to be filled up with material stored to hand. You could put away a lot of learned authorities in the Ditch, and ensure their ceasing from troubling by piling chalk off it over their corpses. Interesting it is to look over the new scars in the aged monument and note how little in all the centuries the particles of chalk in various sizes and weights have shaken down towards consolidation. You could scarcely believe in sufficient force being used to heap it up so as to remain where it was shot, even if the old 'uns understood barrows, running planks, tipping, and such details of navvying. How could the nuaterial be so loosely disposed, or stand trampling, if the barrier was used for watching and fighting purposes? Loose it is, and one-fourth of the bulk, I should say, consists 
of interstices, if I may put the situation that way.

Nobody seems to find much while dealing with the ditch, but you would expect some oddments to turn up or be turned up, if only the early British, Pictian, Roman, or other navvy of the long ago's "old man." What is an "old man"? As I understand the article, it is the little miniature wooden spade thing that dealers with dirt-i.e., ballast of sorts-use to clean their spades or shovels with, and for handiness stow in the strap below the knee that keeps sufficient play in the breeches to obviate tension and strain in stooping. But, there, perhaps our ditch-makers of the dim far long ago couldn't accommodate an "old man" in a strap round their trouser-legs because, not wearing the things, there would be no place for the cincture and, by consequence, none for the "old man." I wonder whether expert navvies could tell you by inspecting the work left centuries ago what class tools were used and the methods. Likely enough, the useful lads I watched playing at being locusts with the grains of corn, taking in turn another barrow-load of chalk, were repeating the "form" of the workers who dug out and built up on the Heath so long before any of us "bought his shovel," which is a trade phrase appropriate to the occasion.

In the days gone by, when at meeting times strangers evidently unacquainted with Newmarket thronged the wide main street and filled all the hotels and inns in search of luncheon, those who did not so attend to that department, or were unprovided with thumbers and like substantial sustenance, had only Jarvis's long 
booth to fall back upon. There was no Rowley Mile Stand, so, perhaps, naturally refreshment rooms in it were lacking. If I recollect right, the tent was pitched about where the "yard" of the present stand is now. Bookmakers betted at "the cords," many of them on cabs and carriages, or in the ring opposite the Bushes, whose wooden stand was removed a few years ago, and a great proportion of spectators made this their headquarters. The judge's box was dragged from station to station, and by the side of the course a flying brigade of horsemen scurried with the racers to the best of their ability. I forget what you paid for the stand, such as it was-ten shillings a meeting, I fancy; but I know that the collectors would not consider them taking any but a friendly view of proprietorial co-operation in putting acquaintances on the free list or accepting fees as a sort of recurring testimonial to themselves, in no way ranking for division; not to mention the takings going into revenuethe Jockey Club's revenue-account. A power of sharping went on between this ring and the winning-posts in quickly signalling the winner's numbers for betting after the event, and there is no exaggeration in stories representing "foreigners" as being on the course waiting for sport to begin while racing was being carried on to the various finishes. Jockeys then wasted in cruel fashion. You find very little wasting by exercise now, which to a great extent is a good thing, because the operation is unnatural and unfair to the constitution. In the first place, a growing boy or lad ought never to go through severe work to reduce his weight. The youngster must lose through the transaction in the long run by 
gaining poundage as the recoil comes, and murderous I call the system for the set manmind, I speak of serious, strenuous efforts to reduce tissue by going in for strong exercise on starvation diet. Barbarous, simply barbarous, some wasting was. You see very little indeed go on now-and a good job, too-of the sort, with a starved shrimp of a chap, overloaded with clothing, frequently so hampered about the legs as to make striding out irksome and chafing almost a certainty, struggling along, physically beaten and organically overtaxed. Old 'uns can stand reducing themselves better than youngsters, but they rely mostly on the Turkish bath. On the day before the Cambridgeshire, Halsey got down to ride $7 \mathrm{st}$. I $2 \mathrm{lb}$. on Love Charm, and would, with his careful management, be little the worse for the operation. Taking some pounds off a youth-and remember you do not start with a fed-up subject in dealer's condition, but a skinand-bone fine-drawn one at best-as Halsey did for himself, might mean lifting his normal weight by a couple of pounds, and it may mean settling him altogether. That has happened before now. The worst waster I ever knew, the least adapted for enduring the process, was the late Fred Barrett, who underwent miseries and dreadful dangers - he had a weak heart-in getting down to steer Alicante for $\mathrm{Mr}$ Ephrussi in the 1890 Cambridgeshire.

In the nineties, when "little" Dick Chaloner was beginning to get a tall, broad-shouldered, big boy, the middle and last Newmarket backend meetings were celebrated in melting hot haymaking weather, and little Dick, with a view to a mount at a North Country venue, had to be 
busy and get off a lot of weight, so as to be able to do 9 st. $7 \mathrm{lb}$. He had a month's notice, to give him a chance, but set to work like a Trojan (did those lying gentlemen ever go out wasting, I wonder?) and plodded along for hours a day with a heavy burden of clothing, in addition to his own Io st. $7 \mathrm{lb}$. or more. My word! how hot it was, and what fine times for anybody seeking to reduce his bulk unless inclined to moisten the clay, and then you put on more than you could take off. Poor Dick toiled and slaved, trudged till his feet went, and bravely kept the muzzle on, for which he was rewarded by being pumped on at roadside pubs., whose quidnuncs took special interest in him on the supposition that so big a chap was training to fight, and was, so far, more worth attention than a jockey. To cut a long story short, Chaloner did at infinite pains get down to weight all right, and kept there ready for duty, and the horse he had wasted for won in due course. So there, you say, all ends happily. Well, it did and it did not, because, as it happened, the gee was given 9 st. by the handicapper instead of being set to carry the extra $7 \mathrm{lb}$. Under the circumstances, brother George was put up in place of the patient sufferer Dick, and all his trouble and mortification of the flesh counted for nought.

That was not so long ago, but we have seen many changes in jockeys and jockey methods. Even at Newmarket on race days you scarcely ever meet or come across a rider doing road work to waste. Of course a reason for this might be found in your going out pretty much at the hours when jockeys are in great demand on the training gallops, but that does not really account for the 
circumstance, because it is much about the same on other mornings and afternoons. Ten years or so back you would be almost certain to pick up a companion, no matter what road out of Newmarket you took. Nowadays you might march about for weeks and not find one on the highways, unless, perhaps, an American doing a run for a short spell. Soon the craft will forget what used to be done, and want teaching what to wear and how to wear it. Certainly some would be better for a little practical schooling. I did, for a wonder, hit on a waster-I mean a jockey wasting; this is no waster-a few days ago, and he was laying himself out to walk in comfort and very natty little pointed-toed patent leather boots fixed up on high heels that added a good instalment of an ell to his stature, and meant shooting the front half of his foot like a wedge into the pick-axe point of the boot. Moreover, he had on hard-like-a-board trousers, eminently calculated to promote chafing, and altogether fitted himself out as uncomfortably as possible. Still, the getup served-at least, the desired end was reached, as the weight came off all right. But at what a cost to his poor feet!

Between two strong interests linked, the General Post Office and the Jockey Club combined, against the Exchange Telegraph Company, has for some time been waged a sort of one-sided war. The news agency tries to beat the Department at Newmarket by means of spirited experiments in up-to-date getting-off and transmitting news by telephone and wire. The Post Office does not carry the war into the enemies' camp by adopting their methods and giving the public benefit of smarter services, but impecies, harasses, 
and, so far as possible, abolishes its unauthorised rivals. "With them" the Jockey Club-and where other course proprietors are affected or deemed to be in risk of being prejudiced, their strength is lent to the P.O. also. The agency's agent gets telephone wires-they are cut or confiscated; employs telescopes - warned off; calls into play tick-tacking of sorts-put down by the strong arm of power, if not the law. I cannot help laughing to myself at a memory this fight calls up, because it shows the benighted slothfulness with which we move, or used to move, and demonstrates to absurdity how intrinsically innocent and well-deserving dodges may be classed as irregularity even to unlawfulness. Years ago, before I880, I think, I was asked to assist one of the tape-machine companies by getting off cricket news from Lord's. The Press "hutch" - as it used to be called, to bring it into line with the shepherd's-hut-on-stilts perch at Kennington Oval-was located in the middle of the long grand stand facing the clock at the M.C.C.'s place. In the ground floor to our bit of gallery were the telegraph-electric, not semaphore-number-board operators. From the first installation of the branch office on the ground it was customary for such as had to dispatch bulletins to make the long journey half the length of this stand's gallery, and do ditto on the ground by the refreshment bar-not necessarily always by the bar-to the office, which was equivalent to going a mile and a half to get over the way, with the difference that our voyage was from one floor to the next. As this company's service-perhaps it was the same Exchange Company concerned in the Newmarket opera- 
tions-was to be very extra specially fast, I was called upon to make adequate arrangements, so fell back on something in the David way-a sling and a stone, in the line-and-plummet direction. With this ingenious apparatus (why did I not patent so clever a notion?) we used to drop the wire that was to be sent, making a descent of, say, eight feet, and thus saving some hundred yards of tramping, which, with the passage upstairs crowded and the B.P. massed below in their cherished haven, the front of the bar, was apt to be tedious.

My method possessed sporting features to relieve monotony and induce pleasure into business. A great recommendation was cheapness. All you had to do was to tie your copy in a loop provided for the purpose, and drop the anchor or stone. Did you not want to retain aid below, below, below-O-O-o, where land-lubbers go, while jolly sailor-boys, are up, up aloft? Dear me! no; nothing of the sort - that is where the charm of the system came in so beautifully. Someone was always about in front of the telegraph office. We Britishers are proverbially polite and obliging, as selves and all foreign nations are unanimously agreed, and all you need do to enlist aid, eleemosynary and ready-made, was to call attention to your wants, which were for somebody to hand the plummet arrangement to the "gentleman in the shop." And if you can't catch a person's attention by dropping a stone of four or five pounds on to his head or hat first, he must be too dense for anything. At any rate, I never found one fail to notice the appeal after the plummet tapped the top of him. Now I wonder whether the Department, if it got wind of my 
great invention, would have warned me off without giving me back the money I had not paid at the gate, confiscated the elegant apparatus, string, stone, and all, and insisted on the old roundabout way being reverted to. Whatever they might have done, they did not interfere, and for days we-self and Exchange Company, if it was so-outstripped competition, as conservative prejudice prevented the opposition from lowering themselves, or themselves lowering a bit of weighted string when they could take so much exercise. Of course, my short cutting had a drawback; the other way did lead you conveniently "contagious" to the bar, which was a consideration dealt with by making occasional excursions to ask the genial gentleman telegraphists whether everything worked satisfactorily. As regards forbidding the plan's execution and confiscating or looting the apparatus, instead of so doing, the office followed. At least, I do not exactly say that the whole of the pneumatic system was founded on my lead, but no tubes had been laid on, and to-day we have pneumatic appointments all complete, have we not?-and of their proper merits modest men are dumb, are I not-at least, don't I ?

While I am at it, and although a few words on Newmarket and this wire-cutting crusade are waiting, I must be permitted to run on a bit about early Press telegraphy and difficulties round which I might spin long yarns. There was, for example, an office at Canterbury. This was in I880. Telegraph offices on cricket grounds were unknown up to 1875 or so, and you were at the tender mercies of local branches carried on in tradesmen's shops. These were 
frequently run, the post-office part, by young persons of severe mien and inexorable, impracticable readings of rules and regulations, who must have spent all their spare hours, including lying awake at night and Sundays at church, chapel, and all, in inventing new dodges for not doing what was wanted. There was, I said, the branch office at Canterbury. It was also a sweetstuff establishment, and mighty handy while all went well, because the mistress herself saw to the wires, and she was a female man of the world with no nonsense-kindly, obliging, and ready to help. But, "alas and alack!" someone next door, or just close, took to keeping bees, the bees took to robbing the shop's stock, and as another apiary "joint" also discovered this food bonanza and, like the former finders, wanted all the lot themselves, both factions got into bad tempers, and made themselves, like the promoted rustic in "The Squire," d-d nasty to some on 'em, including the shop's customers. Once I got among what appeared to be a drunken swarm. That was enough for me, so that handy office was closed. Now, at St John's Wood you had to walk all the way from the far side of the play to beyond the church, and there cope with an awful person on her own fighting ground. She might condescend to attend to you at less than a quarter of an hour's notice. Again, she might not-most likely not-and when she did take the wires in hand you had only just begun. Besides, if she wanted her lunch, lunch it was, and you might go to the devil-which was awkward, because the "interval" did not allow for much waste of time. Then the commercial instinct had to be considered. Buns, bread, and so forth 
paid better than telegrams, and accordingly confectionery customers were given precedence. Let even a kiddy come in for a stale halfpenny bun, and the counting of your telegram was suspended automatically. An old lady who wanted her savings-bank book audited would lose you the first edition of the evening papers for sure. And when you had lodged your batch, and settled up, you hadn't got them half off, because, despite furious remonstrance made to the head office, the Terror in charge made it a rule to let the things accumulate till there was enough work to be worth while attending to in a lump. Further, as a matter of tidiness, she used to plant the forms face upwards as they were taken in-a scheme that ensured the earliest deposited going away last of all. That, I remember, was done elsewhere, at West Brompton, on the day that George beat Cummings at Lillie Bridge, and ran his mile in $4 \mathrm{~min}$. I $2 \frac{3}{4} \mathrm{sec}$. I played every conceivable dodge for getting the result into the office first, and did so within seconds of the finish. Three hours later my message dribbled through, sent off last of a pile a foot high.

I think, without wishing to crack ourselves up unduly, we, the English people may consider that a grand object-lesson to foreigners was presented in the way His Majesty, when Prince of Wales, was able to amuse himself, joining in the national sport in its headquarters free from any restraint or apparent consideration for personal safety and such embarrassment as is carried by inconvenient attention or misplaced manifestation of loyalty. Everybody would be aware that measures always were taken to guard against danger to the Heir Apparent from fanatics or 
other homicidal lunatics; but, for all one might see, the Prince would take his ease at Newmarket without bodyguard, and like any other member of the Jockey Club, or, for that matter, the least inconsiderable item of the congregation. His safety was no doubt studiously guarded, but the way in which he went about showed plentiful faith in precaution being unnecessary, if advisable. Scarcely in any other European country might a parallel spectacle be presented to that of the Prince of Wales riding on the Heath, with only one attendant, and perhaps no one else in sight, or strolling solitary in the High Street, "all by himself," "single-handed," yet with any amount of traffic going on near. Many have quoted this quite ordinary occurrence as one for Prince and people alike to be proud of because of the confidence shown-and merited; and, to be sure, so it was, for its being possible spoke volumes. Moreover, the British Public came out strongly indeed, thanks to their common-sense, grasping the situation to a nicety, and doing exactly the right thing at the right time. For this same the intelligent foreigner might have blamed instead of admiring them, drawing conclusions wrong as wrong could be. To pass such a personage without appearing to notice his presence and make no formal recognition by way of hat-raising seemed gross breach of good manners, to say the least of it. Quite a mistake. A hundred, or for that matter a thousand, might do this altogether with good intent perfectly fitting the occasion. Only kindly regard was shown in what was open to be read by the uninitated as disrespect, but was really in accordance with an unwritten canon of Court etiquette. 
The same Englishmen who gathered in crowds at Ascot to cheer the Royal procession, and were at Epsom equally demonstrative, made no sign at Newmarket-at least, not before or after racing.

One mostly feels sorry that one's memories are memories and no more. Here is one bygone which was not a truly enviable distinction. Headquarters, you know, is usually very trying for the ordinary punter. Only bookmakers and the truly inspired ever seem to win there. Ending a bad season on the Heath as he began, a defeated sportsman announced at the close of the Houghton Meeting his intention of then and there washing his hands of Newmarket racing. "You will have to go a long way from the stand to do it," quoth a friend; "you can't wash your hands here, not if you offered a fiver." Neither could he-I mean the washing-which seems to me to be rather a pity. He would be safe enough in chancing the five pounds, not for ever, though. At last, staggered but rejoiced at the marvellous innovation, quite by chance I discovered a real wash-basin, not a property affair, but with real water, real soap, and a real towel laid on. Not only one, but a pair of these treasures were modestly concealed behind the cloak-room door of Tattersall's ring. All comes for him who knows how to wait is quite true, perfectly correct. I only waited ever since the Rowley Mile stand was built, say, a quarter of a century. If you know how to wait long enough all does come, though you and the arrival may be antiques before the ship comes home. 


\section{CHAPTER XV}

RAMBLES ABOUT NEWMARKET

Newmarket, just like Brighton, does not suit some folk; in fact, makes them owly blinky, and almost inclined to admit that they understand what biliousness is. Personally, I might pitch my camp for years on the East Coast and never get that same kind of upsetedness. Still, there is a natural remedy offering-viz., to take plenty of exercise, as so very few visitors and scarcely a resident can be found guilty of doing. Who in the whole blessed place takes advantage of fine weather by making overtime as I am always advising in the early morning? I cannot understand where the turn comes in starting the day, pleasure or business, so late. Very few of the Newmarket shops are open at half-past eight, and they are not out-of-the-way late either, because in half the country towns you seldom can buy anything before nine o'clock. I do not want people to work harder than they do. Still, this arrangement strikes me as having distinct disadvantages for the majority, and an unpleasant suggestion that either the clock is merely turned round and a late opening followed by a corresponding shutting up, or that the traders and 
others concerned start later than they used because there is less to do. Anyhow, there I was at half-past eight, having helped myself to a quite nice little holiday outing, and unable to make two or three little purchases simply because the sellers were not in sight. A few people were about making for places of business, but in the early afternoon of Wednesday the old "old" you could fire a cannon-ball down the street without hurting anyone called for your notice. I had hopes that someone had told the inhabitants what fine weather was going on, and they had started off to look at it. No living sign of such alarums and excursions were to be detected in the neighbourhood, however, and one felt almost blamishly selfish in utilising so much enjoyment at your disposal gratis, with scarcely anyone helping himself to the goods provided. It is such waste of good health, at almost any time of year. Take a really cold but fine day at Cesarewitch time, what a morning for outdoor exercise! With the roads washed clean of dust, and mud also, all the landscape glazed with hoarfrost, a clear sky, and not too thin a pair of breeches, a gouty misanthrope might possess himself of a light heart and go it all the day, merrily o'er the footpath way, also over the stile-a. Tonics, tonics forsooth! tonics out of chemists' shops! Throw physic anywhere you like, the stuff you take out of bottles-I know all about that, because I have a mania for tasting anybody's medicine. No matter whether it is for a chinked back or the black plague, I can always do with a taste-and stand on strong exercise a-mornings in wintry autumn, while the air is crisp and makes you want to run instead of fairly heeling it and 
toeing it. I suppose I should grow tired of Newmarket if I lived there; but it offers rare scope for tramping from village to village, with considerable diversity of country from down-land (it is not my sort of down-land; still, let that flea stick on the wall, as the medirval French so politely put it) to fenland, and from fen to moor and marsh. Villages are plentiful, and in all is good ale, with conversational landlords, given to pets-dogs, jackdaws, jays, rabbits, ravens, bantams, cats, and pigs, most of whose acquaintance is purchasable by bribery and corruption in the way of biscuits, nuts, scraps of meat and lettuce leaves, or a carrot or two. The dogs will eat anything down to cold tea-leaves almost, if they see any other creature go for them. Biscuits appeal to all the birds, the pigs, the dogs, the chickens, and the cats. At any rate, if the raven does not want them it will collar its whack rather than let anybody else get it, and the "jacks" are game to take anything within their reach. Even if badly equipped, one ought to draw much pleasure out of Newmarket at this season; its environs are in places at their very best just when the leaves are almost on their last legs or stalks, and the belts of beeches make you-or, at least, make old Thames men-think of Cliveden Woods, also Cookham, whose variegated horse-chestnut has been broken, at any rate deprived of its stripes. Mind you, Newmarket's belts of beech and Scotch fir want a lot of beating at their best. Supposing you know and care nothing whatever about the noble animal or the great game. You can still get a good deal out of Newmarket. One July week, my Editor says to me, says he, "Take a rest. To do this, go to Newmarket as an 
amateur-a visitor laying himself out for amusement only. Cast yourself behind the Ditch. Get yourself bitten by the flies. Avail yourself of that hospitality for which all your Newmarketowner, trainer, jockey, and other-friends are so renowned. Do yourself well, but never worry about business. If you like to jerk a bit about the environs of Newmarket, well and good. Disport yourself in the vicinity. Spread yourself around, and, being strictly a holiday-maker, endeavour to write something which will make all your friends envious of the opportunities afforded you of roaming about. Whether you make capital or not out of your little trips from Newmarket's centre can be of no consequence to you-at least, you may as well write about them. Take a round of the villages, as Fred Webb used to do with his fox terriers for companions. Renew acquaintance with the innkeepers" (how the devil did he hear about me and the innkeepers?), "their children, dogs and cats and pigs, and their customers with whom you have established acquaintance. Let us hear how the game is going on-not the great game played on the Heath, but the pheasants and partridges, also the hares and the rabbits and the small birds, also hawks, rooks, etc. Pick up a few notes about the wild creatures, scarce and familiar, and if you can't go far enough for yourself in the study of wild flowers and what some of us term weeds, also flies and fossils, persuade the eminent authority-a great all-rounder in entomology 'and all'-Mr George Verrall, to give you a lift. $\mathrm{He}$ " (says the Editor) "is as choke-full of knowledge as old Sol Gills, and has at his finger-ends all the scientific learning which makes dwelling in 
or a trip to these parts a never-ending pleasure till the visit, more or less lengthy, is over. Toddle off to Wicken Fen, that remnant of the old Fen country-almost the only sample left in this now well-drained county. Take a turn at $\mathrm{Mr}$ Willie Gardner's grand golf links at Worlington, and while there travel on to Mildenhall and Barton Mills to inspect the fishery. Do not forget to see how Kennet and Kentford; Soham, Fordham, and Snailwell; Exning and Burwell, Cheveley and Saxon Street, Bottisham, Swaffham, Dullingham, and Wood Ditton (a nice round that), are doing themselves. Be up and about early and finish off late. Give yourself plenty of spare time and rest, and, in effect, be busy all the while."

I carried out my master's instructions to some degree. I did go to Newmarket, and I ranged about the country. I foregathered with $\mathrm{Mr}$ George Verrall, and was at once delighted and instructed by his conversation, in far too scientific terms for a very humble smatterer like myself. Dogs of my acquaintance, cats who know me, tame jackdaws who are aware that I am good for sugar, and captive jays accustomed to my attentions; landlords and landladies pleased to see me again, pigs which grunt welcome and are glad for me to steal and administer forthwith the allotted fodder-so far as you can call by the name of stealing the act of ancicipating their feeding-time by annexing for that purpose the provender laid out for them-were looked up. The little kiddies at roadside cottages who are so happy if they get a stray copper to put in their money-boxes; the good lady who years ago was so vexed with me because I declared myself out of work, being by 
trade a Hot Cross Bun maker, and so only wanted for labour once a year; the gamekeepers who do not mind my wandering a bit because they are familiar with my ways, and the watchers who so sedulously look after the young birds and tell me their troubles, especially with the rooks; the clever housewife who brews her own beer in the scullery of her cottage-jolly good ale it is, tooand gives it to me because she dare not sell it (a transaction by which both of us profit), and always gets a mug ready when she sees me coming along ; I visited them all. I could not help walking the course, I walked the course. Why do we say walked the course instead of walked along or over the course? I can understand "waltzing Matilda" or "humping your swag," but walking the course I cannot. Anyhow, I padded the hoof from the Cambridge road, where horses used to be started for that iniquitous fancy race the Whip, over four miles, Io st. each, to the improved angle at Choke Jade, and then on to the Rowley Mile finish, past the place where the post-the red one - used to be, and then up the Cambridge Hill's finish, and the sole wrack left behind of the Top of the Town fixings, the eye-headed semaphore thing that marked the winning-spot, I believe. Very tiring walking it is, all over the Heathnot a patch on Southdown footing, and scarcely anyone or anybody was about-only a shepherd with two extremely rackety bob-tailed pups and a flock of black-faces, the most graceful sheep we have, built quite elegantly about the neck and shoulders, not at all unlike fawns. I inspected the Limekilns and Water Hall, the Racecourse side, and right along from beyond the Ditch to the far-away starting-point of the weary Beacon 
Course, on which are run races that, considering the awful weight carried and the distance, four miles or so, are a disgrace to racing civilisation. On the Round Course, now a dreadfully dilapidated track, I voyaged. I interviewed the good lady at the turnpike-house by the corner of the Ditch, and the other lady who also sometimes refreshes me with ginger beer, the semi-official tenant in charge at the corner of the road which, at a mile from Newmarket, branches one way to Thetford and the other to Bury St Edmunds. I met, jogging along, the higglers and hucksters who make marketing so cheap in Newmarket town while the shopkeepers hold up prices so dear, and I said "How do?" to the noble local army of unauthorised tipsters, who can and will tell you all the winners, and are sure to be right, because they are always hard up and stony-broke themselves. I did the lot mentioned and a good deal more; and when you have done the same you will feel you have had a run for your money, or I am mistaken.

Mr George Verrall put me up to the habitat of a certain very, very rare English flower. Describe it, not me, I would as soon put in print the whereabouts of a scarce bird seldom seen on our shores, and get the poor thing murdered. Once upon a time, a philanthropical botanising old party of my acquaintance was "put on to" a choice fern which he wanted. How do you think he showed gratitude for the tip? How? He improved the occasion by lecturing to a company of able-bodied loafers, hangers-on of those parts, and informed them of the thing's merits and beauties, chucking in plenty of long book words. And how do you think the don't-want- 
no-work-to-do brigade went to improve the occasion for themselves? They tore or dug out every blessed root as soon as the elderly party left with his specimens, and cooked the lot. Their idea of vegetable goodness was being good to eat, which the fern most distinctly was not. That historiette has ever been a warning to me not to give away the runs or pitches of scarce animals, birds, fishes, flowers, butterflies, beetles, and the rest, so no more from yours truly about this special decoration.

Newmarket's more remote suburbs on the Suffolk side, parts seven to more miles from Jockey Club headquarters, are unknown to the majority of its dwellers, not to mention visitors. Wild, strange land, this terra incognita for many Newmarketeers, lies handy to the east end of the Heath, some of it so poor that it seems nearly good for nothing except growing firs, rabbits, and plovers. The soil is sandy and poor in places, saturation level is only two feet down or so; trees generally are stunted, though some do better; and the impression it gives is that those who tried to do anything with it were sorry they ever took the job in hand. Many traces are there of unsuccessful effort in this direction.

A stranger seeking directions for skirmishing in these regions must be much struck (till he understands the derivation) by the peculiarly heraldic nature of certain points. As example, here are a few which the wayfarer between Kennett and Mildenhall may be told to make for: "Cavenham Plough," "Tuddenham Anchor," "Barton Bull." These sound like village names or parishes, with their ancient appellations done 
into English from more classic samples, like Glen Parva, Ashby-de-la-Zouch, Kibworth Harcourt, or plenty you can find. However, investigation reveals that what might be a sort of surname or qualification merely refers to the local pub.from time immemorial the most convenient landmark, far superior to the churches. Other counties, other manners in speaking. Farther south you would say the Swan at Bottisham, and be understanded of the people. In the east, where the "a" of ham is scarcely indicated, not to say sounded-as, for instance, Sohm for Soham, Swaffm for Swaffam-Bottisham Swan is the vogue with the "a" squeezed out like " $i$ " in Narrch, spelt Norwich. Pleasant hamlets, villages, towns, are the scattered locations between Kennett and, say, Mildenhall, with individualities, manners, and customs amusing to study, and plenty of churches built when money was of more value, labour fairer, and the Church had more to say, or, at any rate, must be listened to more. A great mixture of soils and "lays" of the land is hereabouts-peat, chalk, sand, clay, bog, or fen; all are mixed in patches or strips, with vegetation to match. You get all sorts to walk on except good roads, but of these I spoke before. Always I have admired the smartness in action of the Eastern Counties' agricultural aid. I admit rating the class, wherever met, much more highly as workmen than do most people. You come across few smarter, brisker labourers than you find in and about Newmarket. Perhaps skating as boys, lads, and men inclines them to good natural pace. Whatever may be the cause, there is the result.

You see the cottage-garden flowers here- 
abouts to much advantage, thanks to local fashion in making parterres on the border line of house fronts and side-walks or bare roads. The kiddies must be educated from their childhood into respecting this sort of property, for no one seems to touch the gay little beds whose boundaries consist merely of a line of stones arranged very much like the "claims" set out on the sands by the sea. Great damage might be done to these pleasure-gardens by a wandering horse, cow, or pig. Are those animals also brought up in the ways they should go, and "learned" not to depart from them? And if this be so, what about travelling flocks and herds?

The Herringswell district is to me most remarkable for the variety of hedges tried on it at one time and another in endeavour to keep the wind from ranging raging free over the land. Allowing for these, the belts, and more spacious plantations, you can easily grasp an idea of what Newmarket Heath used to be like when doubtless all the part on the Bury side marched with the country I speak of, one great waste, practically treeless. Thousands have been spent on remedying nature's shortcomings in failing to decorate the great plain. Three miles and a bit from Newmarket on the Norwich road commences an avenue (mainly of elms) a mile and a half long, a good companion to the long row of beeches bordering the Duchess's drive going to Cheveley. Between Kennett and Herringswell is an avenue of sycamores that runs a long way, and has not much longer to run without running down, I fear, for they seem to have got pretty nearly all there is to be had out of the poor soil and are quite past their meridian. 
My first object in revisiting Herringswell was to look up its fir hedges, a form of barrier and wind shield very unusual elsewhere, so much so that I have not yet come across anyone to tell me how to make them of the most suitable material-spruce. Properly treated, they are most useful and ornamental. No others act so perfectly as a green wall; these are far more substantial than yew (mostly a hollow sham), grow very quickly, are easily trimmed on their faces, and after each annual cutting give first a pretty display of aromatic cream-coloured buds, from which shortly come early shoots, delicate in their greenery, a delight to the eye in their cool tone, and a strong barrier in their interlaced face of little feathery branches. The Scotch, of which are many, are always a trifle on the gloomy side, with so much dead wood and matted dropped spines about their lower parts, but still, planted two feet only apart and kept lopped, form a capital barrier. Being neglected for a while they grow out of all order, and into fantastic, eerie shapes, yet are mighty exasperating if you want to get to their other side, because you can't squeeze through. As I could get no casual information anywhere on the manufacture of spruce hedges, I applied to a gentleman who owns particularly fine ones, and he most kindly explained. You let your young firs grow till they average as high as you want your hedge. Then that year you just take the top shoot off each, and next year you begin to clip them. One essential in keeping a green hedge thick and well foliaged all the way down-viz., slanting each face, when clipping, outwards towards the base-the natural 
shape of the young spruce will almost ensure, at any rate for some time.

So good-bye for the time to the fine domains (oases in deserts of waste) which have seen better days, and those that have never, perhaps, been so smartened up as now, when the old acres are in new men's hands; the churches, which some of them could do with a little of the money spent by the latest country squires on rough casting and half-timbering cottage property ; the brooks and the drains; the little rivers; and the odd outlying scraps of fen, remnant, I presume, of a period when the water was a good deal higher; the big fine trees that are lucky in their soil, which is good, and the others who not being well fed do their best on short commons and hard blows ; the cheery "hinds," who get over the ground fast, and the quick-stepping team horses, the wide-sided sheep, and the leggy lambs, the wood-pigeons plunging out of their cover in the tree-tops, and the peewits, who continually do cry, but who if they-may I be rude enough to say it?-had sense enough to keep their mouths shut need not put in use so many tricks to deceive. The casual observer wouldn't know such things as plovers were about unless they went out of their way to advertise the fact. Please let me take breath after that sentence, and in a fresh start not forget the squirrels and the myriads of moles, the small birds who have been woefully deceived this season in nesting before the leaves came out as they promised, and the greater birds -pheasants and partridges-generally speaking, all over the place; the rabbits by the thousand and the hares by the score; the briars sweetly scenting the air, whose force bruised them to the 
wayfarer's advantage; the great woodpeckers, cheerful chatterers, and the jays, who can't be made to rank that way, friendly as you may be inclined, the swallows, who were few, the martins fewer, and the sand-martins scarcer still; the butterflies, about one to the square mile; the larks and all the other songsters, from the misselthrush up among the tall elm tree-tops to the nightingale in the bush at its foot; the affable long-tailed wrens in the reeds, and the melodious modest hedge-sparrow - worth, to my mind, a gross of the much-too-much-over-written nightingale; the genial roadmen, and the bakers, butchers, and other carters who offer a lift-as a matter of course and courtesy-and the good folk who are at home under the sign of the Plough, the Anchor, and the rest.

I cannot help once more talking on what appears to be a very favourite subject, roads and milestones, concerning which we have again had many interesting letters from and for Refereaders. Now, on my own, and with particular reference to the dubious starting-points of road measurements, let me ask the many friends who visit Newmarket if they know where the town milestone, the one from which the to's and from's Newmarket announced on various routes of approach or departure, dates? Often I used to seek for the memorial, and vainly, since natives can only tell you about where they think it is or ought to be, and go no nearer absolute precision. I can mark it right down. On a house ( $\mathrm{Mr}$ Barrow, the chemist's) opposite the Rutland Hotel you will find it, round the corner, set at right angles to the road line. I may add that by the time you have walked a couple of miles from this, straight along 
the Thetford road, past the first milestone, hard by the old toll-house at the junction of the Thetford and Bury roads, to where the second ought to be, you will come to a "remains" in place of the complete article. The stone post stands all right, but the iron plate with the numbering and lettering has been smashed. Whatever satisfaction do vandals or boys (a boy is not anything at all till he grows out of being a boy, so vandals or boys is correct enough), derive from perpetrating such outrages? I never can make out. One can understand the hackney drivers in the Derbyshire Peak district defacing the milestones, because by so doing they prevent travellers from telling what distance is driven; but doing the harm simply for deviltry is almost unaccountable. Still, perhaps we ought not to talk too much on this head, we old 'uns. Not ten minutes ago, wrenching off knockers and bellpulls (even doctors', who ought to be safe) and smashing street lamps was considered high old sport, so the other form of annoyance is not so very unaccountable after all. I wish it was far rarer.

Some uncertainty exists as to the one mile downhill at Newmarket, which Bill Lang, the two miles record holder (recently attacked, I mean on his figures), a lovely mover indeed, ran in $4 \mathrm{~min}$. and some seconds. One is, perhaps, apt to lay too much stress on early fancies. To say that praising old times is natural, covers a very obvious truth - viz., the likelihood of your ranking highest what you saw of excellence when you, the critic, were young, full of enthusiasm, less inclined to search for faults, and far more prone to become a partisan than you are after long years of experi- 
ence. Allowing for all that, I should take a lot of persuading that a better mover than the Crowcatcher could be made. You see that if he ran between the stones from the fifty-eighth on the flat going nearly opposite the Old Cambridgeshire stand to the one we have been talking about, he must finish up a steep hill-a hard job at the end of a fast mile. My belief is that he was set to cover a measured mile finishing at the Rooms, and I am almost certain that I am right.

In July a very delightful resort is the Heath, no matter where you go-on the Cambridge or Bury or Thetford side, up along by the Cheveley road, or across the Moulton, away to Water Hall, or getting alongside Chippenham Park. For its area the great plain on the Race side, and so far as it is bounded by the Ditch, has probably fewer components in its turf than any other grass land, barring seeds. One sort of grass predominates and dominates, save for burnet, which I want to see tried on its own for making gallops. Wild flowers there are, but not in profusion, on the town hand of the July course. Over the way there they are far more plentiful, so are the sweet scenty herbs that make Southern downs so fragrant and healthy. Now, if you take a square foot of Southdown turf and divide it up, planting its members, you get a surprising catalogue of variorum growth, not forgetting crops of samples from seeds lying dormant and doomed to be starved should they germinate in their original stores. I would like to bet that a turf cut off Epsom's or Lewes's, Goodwood's or Brighton's training tracks would furnish manifold more varieties of vegetation 
than one taken at Newmarket on the Racê side. No two opinions can be as to which makes the best going, allowing for difference in thickness and arrangement of soil and subsoil, and I wonder whether, where herbage has to fight for existence, safety to horses going on it does not lie in numbers of different material brought in for use. The July courses beat the Rowley Mile all to nothing for thickness of felting, elasticity, and deadening hoof-strokes' force. The former are carpeted with a very extensive omnium gatherum, grass forms nearly the whole of the other.

The Dullingham road was formerly beloved of jockeys wasting. Do they ever work hard nowadays as they used? They may. I never seem to come across them, and I have the evidence of a very old iishabitant of these (Dullingham road) parts that he does not come across them. This is the aged gatekeeper of the Great Eastern Railway Company's level crossing, where I recollect him for years and years; and a handy chap he was, too, in summer, because his cottage hard by has a well of most beautiful, always icecold water. In the days when jockeys were plentiful on this highway the gateman timed himself so as to be ready on their return with a jugful freshly drawn for purposes of a splash on the head, or a gargle, most welcome and refreshing, helpful to keep the pores at work, and freshen the body up without interfering with the weight. Jockeys would tell you that they preferred this walk to others radiating from headquarters, because it is sometimes so shut in by high hedges, the sort which were conventional but went out with picturesque farming. A great 
screen, fifteen or more feet high, they make, very charming to the eye, given to much bloom, also bird-food producing, making rare harbour for nesting, and apparently constructed to order for felts' winter operations. Our young and older friends, the overweight riders, did not, I fear, look on them with other than utilitarian eyes, as a species of vegetable curtain hung to keep the wind away, and so negatively promote perspiration.

Not for a long while have I been down along this road, which proceeds through a gap in the Ditch. I can recommend the excursion to strangers-viz., to take this highway, and then when they get to the Ditch, turn up to the right and keep along its ridge as far as they please in the direction of Reach, on Fenland's edge. Somebody, I noted, has put up a notice to the effect that no footpath right-of-way exists. Perhaps it has been legally juggled out of existence ; perhaps it can be asserted or reasserted; but I should think that Newmarket will not quietly stand this bit of grabbing. So far as I heard old folk talk, this Ditchway was ever the regular walker's route from the fen to Wood Ditton. The section on the east side of the Dullingham road was shut up some time ago, and now the rest will go unless somebody makes a fight. The notice-board did not stop me, but, to begin with, the usually dry grip, or ditch, by the roadside was a rushing torrent on a three-feet-deep-andtwelve-feet-wide scale, and if I got across that I couldn't have climbed up the steep bit of the Vallum if you paid me a pound an inch. So I made believe I didn't want to go that way, nor up to Dullingham, where is excellent cool ale 
(many a bait have I had there, and my friends the wasters too), but had come out a-purpose to just loaf and listen to the birds, notably the nightingale, whose notes just now are so remarkably like some of the thrush's that you don't care to bet you know t'other from which, unless you can locate the level of the song; also to the sheep and lambs' nursery conversation, and have a word or two with friendly wayfarers, who talked of what happened in the rain two or three miles off, as a Londoner might of earthquakes in Java or forest fires in Canada.

The Dalham district makes another very charming field for excursion in summer. You do get some beautiful country over that way. Fond indeed I am of this remarkably picturesque rustic hamlet, its church and churchyard, the sort which, beholding, you can swear has a big house or place adjacent; sweet are its hill roads lined with ivy-grown trees of various stems and crowns, as, for example, ash, maple, holly, with hedges clouded over with English clematis, traveller's joy, or old man's beard; the beautiful avenues, and, most interesting of all, the graveyard records. Lanes you have like to the deep, much water-worn packhorse ways you find in Surrey and Sussex, and all the typical plants and flowering shrubs peculiar to chalky lands. To me a much greater treat cannot be had than to walk by the side of the brook or bourne to which locals are shy of giving a name, to Moulton, where the good folk call it the Kennet-a puny, deserted waterway track in dry weather, but of consequence in flood, as high arched flint bridges of remote date testify. Cool and refreshing to the ear is the trickle-tinkle of the streamlet, to 
whose shallow pools doves and wood-pigeons were resorting. Kind to the eyes was the copious greenery on the brook's banks' sides, dotted with pollards of sorts, oak, willow, elm, and alder, and the grenadier growths from the bed-level, reed grass, meadow-sweet, and wild parsnips-mumbles they call them in those parts - six and seven feet high, great billows of wild roses, wide discs of elder, carpets of rock-rose on the shallow angled banks, and everywhere the scent of new-mown hay, with now and then the faintish fermenting sweetness of stacks " making" themselves. Birds, deeming themselves safe, were friendly, except the chats-who must chat if every wish of theirs was gratified-and the butcher-birds-scolders much in the chat styleand a couple of mother partridges, who, for my benefit and their new-born chicks', played at being broken-winged, and scuttered round (after the manner of Cossack dancers as presented on the stage), running on their heels till all the brood were out of sight. Then, with a warning note to the family to stay where they were, and a cheeky chuck to myself, off they winged it, sound as a bell, and twice as saucy. These and plenty more delights were mine on the walk, or wade, for, like the Tennysonian agricultural gentleman, I was in the sea of meadow-sweet, or something equally nice. But, after a visit to the Afflecks' old domain, I always am a bit sorrowful now, till well clear of Dalham, for thinking of the good peaceful time Cecil Rhodes, who bought the park and place, should have had, a reward he surely earned, and his lying in the land so far away from home; and how, soon after, Colonel Frank Rhodes was carried home there to be buried in 
the little churchyard within the walls of the park which his brother left him. A great grief to the hamlet his death made. It is good to hear a man new to the acres spoken so well of as is their last master, whose possessions I used to envy, with the reservation that having to leave them would be so hard. 


\section{CHAPTER XVI}

DONCASTER

I ALways count good for the voyage down to South Yorkshire by the Great Eastern, of whose line on this road I am very fond. In one way and another it keeps me interested, though occasionally I find myself realising that as I was there at the time I gathered odds and ends linked with the line, other people, contemporary chiffoniers, must be getting beyond the first blush of youth, although personally I may not be. So far as I can make out, there will not be any old 'uns soon to whom a body can refer about former times, a point which, at a more convenient season, I would, in Mr Midshipman Easy's words, like to argue in a way. For instance, you might amuse yourself with speculations as to the feelings which come over an oldest inhabitant, the sort of person whose evidence commands good prices in right-of-way cases, when he is first promoted to that proud position by virtue of seniority. I am not yet in a doyen line of business, but may confess that not long ago when bent Doncaster-wards I told my cabby to drive me to Bishopsgate Street Station. "The Eastern Counties, in Shoreditch," says I, by way of 
making plain for $\mathrm{Mr}$ Jehu, who politely said, "It ain't the Great Eastern in Liverpool street, guv'nor, you mean, is it?" How many years has the aforementioned depôt been disestablished and the company's style or title been abolished? A long while. London is not half so interesting now as it was in the days of old Bishopsgate Station, when the racing army mostly went down to Newmarket on Monday afternoons with a Sunday's Bell's Life to read, and a fine view of myriad pigeon-lofts on the roofs of the houses in Shoreditch, Bethnal Green, and those parts to look down upon; also the parties concerned in such aerial bird-coops, always busy, apparently, like the nigger, disregarding the minister's direction, not to covet your neighbour's poultry. Then good yokels came to London once in order to be on the same platform of cosmopolitan experience as rival inhabitants of the past, and be able to say they had been there. For them were the Shoreditch "houses" with good old East Anglian signs, mostly names of towns, selling, likely enough, Norfolk ales; Deacon's entire, for instance, proclaimed connection with Yarmouth. In such hostels you might on the occasion of excursions find groups of villagers up to see London, who saw it from the inside of the pub., and didn't stir from their close retreat till due to catch the return train. In the interval they herded in a lump like frightened sheep or rats in a pit, regarded all but their own crew as workers in various walks of dishonest industry, and kept their hands in their own pockets so as to pre-occupy those strongholds against the enemy.

Please do not take me to mean that being a 
little absent-minded I directed the cabby to take me to Bishopsgate's old station, because I used to go thence to Doncaster. There was no joint running between the Eastern and the Great Northern Railways then, which was a pity, for the new is a pleasant road, making far more comfortable travelling than I can recollect on my first journey to the South Yorkshire town. Five shillings return I paid, I believe, and was on the road from 5 A.M. till 3 A.M. next day, or something like that. In the interval I assisted at Lord Lyon's victory over Savernake. How one can recollect far-away occurrences! Plain as the house was before me as I passed it a dozen times this last week I can see the little Marquis of Hastings in the Salutation Inn yard where the Danebury horses stood, I believe. Anyway, there was the Marquis, also the Duke of Beaufort-what a splendid swell this John of Gaunt was, a marvel of make, shape, power, politeness, and the grand air always! - and from the former I heard that Rustic was scratched, which was good news-at least, to me, for at that early stage of business life I was a dabbler in wagering, and Rustic's removal suited my book.

No one but a madman could have dreamed of making such a book as I put together, going as solidly as might be to get myself broke in "one pop," as the word goes. The road to wealth seemed open to me then. So it was, if I could command such results as came my way while I was resolutely plunging down the road to ruin. Talk about playing the high game, to do which properly you lay against one horse and put the money you are going, with luck, to win on 
another! That was only half high compared to mine. Never, I believe, before or since has there been such a volume as mine, and I can recollect each individual bet. A fielder's business being to lay against favourites, I began by backing Lord Lyon. Then, to save that money, I laid against Savernake to win and Rustic each way, backed Lord Lyon for a place (Valentine and Wright, now Topping and Spindler, sent me a voucher for this like a dock warrant) and Savernake I, 2, also backed Knight of the Crescent I, 2, 3, and wound up by taking the ridiculous odds of 25 to I that I placed the first, second, and third-and performed that feat.

Often I think about that precious book on which I won every wager, and wonder what idea I could have had of risks. Musing on the insane successful speculation took me on Monday far beyond the chain of those most countrified-named once villages-Bethnal Green, Hackney Downs, London Fields, and on by Lea Bridge, where I shunted on the mental train to memories of days in, on, and about the pleasant waters of the river Lee, or Lea-it is spelt both way, though the bells of Shandon do not sound so grand on this "L-double-e," or "L,e,e," as I believe one must say now. Hackney Marshes appear to be turning themselves pretty much into waterworks now -do they not?-like all the Thames Valley on both shores, Middlesex and Surrey, between Hampton and Walton or Hanworth. Soon there will be no room for the people who drink the water, but that does not matter any more than the disappearance of the marshes, once a playground where one used to see all manner of sport. 
Why, I recollect-but perhaps I had better recollect that I want to get to Doncaster and have only about half started so far. We will, therefore, skip the beautiful strip of low land between London and Cambridge which somewhere about half-way has a "divide," with the Stort going south to the Lea and the Cam north to the Ouse, and do ditto with Hereward's hunting-grounds in the fens. At least, I must have a word about the fenland because of the Mark Lane simple countrymen, fellow-travellers, whose talk was of all manner of grain-and who quoted each other's rates at odd halfpence, and apparently knew as much about machinery as an engineer. From them I was delighted to hear a generally optimistic account of the corn harvest. Fine indeed were the cereals all through the fens, and the roots.

I take quite an interest in roots in the Doncaster connection because of the (alleged) nonodoriferous sewage farm, run, I believe, by the Corporation. Non olet is, as all are aware, one of Danum's mottoes, and it acts up to that same, being conveniently stone deaf, colour blind, or what you call it where perfume is concerned, and the town's reputation for Arabian scentiness. This farm, you know, abuts on the town moor, and goes a long way on the road towards Thorne, where the bargees replenish their store of pure water from the Don. Unfortunately I never can crib time enough to get down the river so far as Thorne, though now and again I manage part of the journey along the Sheffield and Yorkshire Canal's banks, doing a bit of surveying on my own account. Amusing going it is, with the canal a designedly winding waterway of consider- 
able current always flowing, and the old river serpentining alongside the artificial, the big levees or flood walls; the farmsteads, banked round as if fortified; a'general suggestion that ague might be cheap, wild-fowl shooting good in winter, and that the monks had a good time when they flourished. Were they ague-proof, the old Churchmen? They must have been hard against rheumatism, for they loved to plant themselves down in the damp, with, if possible, a moat or a stew-pond to keep fish in and give off malarial white mists. These old 'uns and their patrons left a beautiful lot of churches round about Doncaster, with stonework of a nature to make one remember with tears that in earlier years he had taken no pains with his architecture. At Brantwith-I believe that is the name-is a Norman porch with one line of hatchet work perfect almost as the day it was cut (not like poor York Cathedral, whose outer skin is absolutely crumbling to nothingness), and circling it a scroll, held, so to speak, by eagles' heads and beaks that a connoisseur would go many miles to see. That is a sight of the village, but to me a more striking one presented itself as I cleared the lock, next to which huge canal works are in progress-you don't come across many new canals in England now, more's the pity-that fairly made me sit up and rub my eyes. What would you say, gentle reader, if all at once, and without notice, you stumbled on a range of, say, two hundred deserted stout barges' dinghies-keels they call them-laid up on a canal's bank, each with a big hawser coiled in it and an anchor? The explanation is this. When the barges working up Sheffield way arrive at this lock they cannot get through 
with the keel because of want of width to take the two alongside of each other, and also lack of length to get the big and the little craft in end-on. So the obvious alternative is adopted, and the two part company, the little 'uns being left till called for, and a rum show they made.

I can recommend this canal for trudging, but you want thick boots, for the barge walk is studded with cruelly nubbly stones calculated to stump your feet up at short notice. Still, I am sure you are well off there fossicking about with an eye for the harebells and the big pink geraniums, the silent pools with moorhens' walks among the weeds reminding you of hares' runs; the big rushes and great beds of meadow-sweet, here and there a water viburnum (an English guelder rose, is it not?), own brother to the mealy one, which former has those pretty scarlet berries that, being taken indoors, do make a horrible mess sooner or later; the fat cows who dispute possession of the grassy bank over the way; the now and then gulls sailing at their ease, and rarely a kingfisher; the autumn crocus, our English saffron, which I couldn't find, though I know where to get bushels not far off at Selby ; the pretty reeds in bloom, and the queer halfbred Irish terriers which abound ; also the patient fishermen, and the all-too-solitary pubs. lying yards below the water's level behind the earth wall.

There is excellent walking on the high land near Doncaster if you know where to find it, but perilous while motors are about. A popular owner's chauffeur all but caught me on the Bawtry road as he skirted round on the off-side, coming 
from a byroad in cutting round the curve shut off by a hedge from view of what might be going on ahead. Can't we pass a law making carowners provide a sort of wire fund to pay for the expense of removing hedges and other sighthandicapping boundaries from corner plots and substituting iron or other railings penetrable by the human optic's range? Thank goodness, motors cannot vex down by the Don, nor on the course itself.

When I used to do Doncaster from outsidegoing into the town in the mornings and out again at nights-I did Doncaster great injustice, because I gathered my idea of its country from the low black peaty land you go through approaching the town from London by rail. That sort of territory is plain enough even to ugliness. But you mustn't judge the place by this sample any more than you should gauge its everyday life and aspect by the race-time performances. Out of these it is a remarkably quiet sort of country town, as these go in the North-you scarcely expect the picturesqueness of the South -and out of Doncaster you can find very pretty country indeed, say you know where to look for the same. Working up towards Sheffield on the canal and river is some charming scenery, which would be vastly improved if you could only so much as make believe that the poor waterways were not more filth than anything else.

Justice must be done, whether the ceiling falls in or not, and as to the alleged local smell, I am bound to say that I believe the horse traffic was often accountable for it. This being thus, I wonder rather that the committee whose duty it 
is to look after the roads do not follow the Duke of Bedford's example with regard to Covent Garden Market and use plenty of carbolic disinfectant for watering the roads. What I want to say is, the Town Council might, if they liked, make their town much more pleasant to visitors at race times if they put down the hawking nuisance. Possibly the authorities have been used all their lives to pass one week in the almost constant din of wandering vendors of "Yorkshire Post," official cards, butter-scotch, etc., and are like the dwellers near a goods station, who couldn't sleep o' nights unless soothed by the music of shunting trucks. Similarly, it may be that our friends would be unable to enjoy their beauty sleep unless they were woke up by yells of "Yorkshire Post," let off at five o'clock or thereabouts A.m. After that very excellent paper is on sale-I do not believe that the abnormally early start helps its circulation in any way-the game of noise-making is kept alive, and the unfortunate visitor is kept awake. That is bad, and the cause is preventable by municipal management. After all, I am not certain that we want Doncaster altered. The smell must be to many of us as was the odour of Brentford to King George. We have become so accustomed to the loud noises that we should probably wake up too early if these were not let off to tell us how much longer we were at liberty to sleep. Moderate the energy of the drivers and drivers' touts, and you will cut out two pleasing elements of uncertainty-first, as to which trap you are to be pitched into and taken carsewey or stashunwey, and again as to being shot out or run over. You had better make up your mind to a diet of ham and butter- 
scotch-engineering these as a sort of curethere might be money in a ham and butter-scotch spa. Consume all you can, get above your proper share of the smell, and, generally speaking, take your Doncaster kindly.

I learned a new thing by observing the Doncaster barbers' shops, and here is a tip concerning the same. When you desire to be shaved, and look into a studio, do not be deceived about the remoteness of your turn by the strength of the "house" waiting in the room or rooms. The lads of these parts are a very gregarious set, indoors or out. They love to herd together, and are most sociable. Nowhere in the South do you see such strong companies as you will at York or Doncaster. They set out together by the same "trip," and stick to each other all the while. So it comes that they go to be shaved in troops, and those operated on first wait afterwards for the others till all have had their turn. Thus you may find seven or eight apparently " before you," all of them clean-chinned and only sitting till the remaining member of the company has been done. A precious habit this to the studious chronicler, because the lads talk. They do talk indeed, and are very instructive. From them I learned that punching has a wider significance than some of us allow to it. The word, as they use it, appears to apply to almost any sort of stroke, to a kick as well as a hand blow, after the manner of the French coup de pied as well as coup de main.

"Did you see bookmaker yesterday?" said one. (I am not going to attempt to render the dialect.) "Him as was bookmaking?" asked a mate, with a good deal of accent on the was. 
"Aye," replied No. I ; " him as was bookmaking.; He won't be making no more books yet awhile." This fielder, so it appeared, attracted my party's attention by the liberality of his odds. No. I was tempted, but refrained. Being a man of shrewdness, he objected to being given "aught," as he would with 5 to I offered on the field and two 3 to I favourites well backed, and the fielder's "being too close to the rails and all." So it appeared he didn't deal, but sought profit another way. "Us'll wait here," he instructed his pals; "happen we'll see some fun." And they did so. At the psychological moment the bookie as was did the North-Country equivalent for a "guy." "Off comes hat, on goes cap, under rail he ducks, and walks off, bold as bull beef, with chaps' brass and all, and was getting clear when little collier chap spots him and starts with stick on to his yed." Then the fun was supposed to begin-at least, the real legitimate entertainment did directly afterwards, when "little collier chap's" repeated efforts "wi' stick" brought the sportsman to the ground, and the punching period set in with great severity. You could hear them punching his head yards off till he couldn't halloa. Lots who had nothing to do with it crowded in and punched him on the head as he lay on the ground. So said my barber's-shop recorder. Forgetting what Mr Joe Topping, of Leigh, told me about Lancashire collier fighting-punching in catch-as-catchcan, go-as-you-please, up-and-down, till one gives in, with no seconds, no time, no rules except beat or be beaten-I asked how such a lot might get at the prostrate welsher to be able to hit him with their fists-the answer was, "I didn't say punching with fists, I meant feet"; and at first 
that seemed sufficient explanation. "Oh, with their boots," I concluded, but was still inaccurate, and had to be corrected with "wi' clogs, most of 'em." No wonder they spoke of the gentleman as "him as was"! 


\section{CHAPTER XVII}

\section{DONCASTER REMINISCENCES}

If you want to see life here on race mornings -I do not mean such as is represented by standing round in a ring of fifty and sixty and betting on pitch-and-toss, which are popular forms of athletics (the standing, the betting, the pitching and the tossing), on the Town Moor-let me recommend the road to Rotherham and Sheffield, and a study of the traps bowling along. Once I took the trouble to go out and look at some of the assembling, devoting myself to the Sheffieldwey contingent, and to that end made out some five miles of the eight towards Conisboro'. Not at all a job. I take to kindly is watching streams of vehicles on the move, more especially if they are coming towards me. I do not know whether there is any personal peculiarity about the sensation, but after keeping my eyes on a long succession of carriages moving towards me I find a sort of attraction in the Juggernaut line, something like the pull a cliff will give at your feet to persuade them to take you over. Moreover, the vehicles appear as if they are leaving the straight line and making for the side-walk. Altogether, I dislike the business very much. 
Still, it had to be done, and was worth the trouble. Most striking about the procession was its wonderful evenness. Now and again you did find a well-got-up equipage-very few, however -and here and there occupants of the swell order - rare birds, indeed, not enough to count really. By the dozen, the score, the hundred, came charà-bancs, wagonettes, very long-backed machines, ordinary landau cabs, occasional hansoms-only a sprinkling-now and then a little lot of buggies, evidently cruising in company by arrangement, here and there a light float sort of shallow, examples of exceedingly comfortable "lots," pair-horse open flies with a very high coachman's perch and a dickey for two behind. No room was wasted; very much the other way about. Three-a-side in the landaus was the almost invariable rule; and as to the wagonette brake division, wonder was how so many passengers could squeeze in or be extracted.

Walkers were many, too, of all sorts, from the well-furnished hand who toddled for choice to the financially broken-down enthusiast who took the only stage within his means; lots of good movers were on, though, naturally, as they were nearing the end of a long journey, not doing many miles per hour. I think that on the whole the section in clogs went better than the leathershod. Between the presumably poorer, who walked more or less like blazes, and the betteroff, riding in chaises, was little difference in get-up or apparent social position. Working folk for the most part, going to enjoy themselves rationally, with money in their pockets to spend and knowledge where to get more when one lot had gone. The driver was as a rule quite on equal 
terms with the fares, and in two hours I counted two tall hats among the lot, and they-the tiles -were of the white sporting coachman's order. Civilisation had spread so far Northwards that little nippers cadged for coppers for all the world as if they had been brought up under the Windsor School Board, who turn out beggars of this sort by the hundred. But chaff there was not, save for one gentleman who, as an overflow customer, sitting on the splash-board, with his feet resting on the pole, gallantly intimated to your humble servant that there was room for two and nowt to pay. Of cyclists were many good riders, mostly going fearlessly at a great pace, and able to do so safely, too, since the tide of traffic set one way only; but never a motor in five miles out and home.

New features in the proceedings I am unfortunately unable to chronicle. The clans gather from all parts, and, as is their clannish way, stuck together pretty much, doing the day in groups, so to speak. Where one went to try the ale the rest went, too, and partook. So long as the majority were pleased with the fire in the pub. room, and the smell-as of a week's wash, forgotten for a fortnight, being slowly brought to the boil-there they were and there they rested. Resolving themselves into a committee of inspection, they sampled the outsides of the cooks' shops before committing themselves to an order. Being at last satisfied as to profitable selection, the group would go in and for the joint picked, and all order cuts off that same. Together they had started by trip train, neatly labelled with names of towns where it called; together they were shot out like coals at a siding; all of a row they 
proceeded, as mentioned, to the pubs. and joined in friendly chorus-eight A.M. is a favourite time for a smoking concert on Sellinger days-and all of a row they would make their way, making way for no one, up the High Street and along the Bawtrey road to do their day's sport, and bet, the lot of them, with the same outside bookie, who would, you might reckon, be safe to settle with them if they won, because the party built round him from the moment their money went on till "Pay!" "Pay!" is called.

I suppose few have seen pitch-and-toss played on the grand scale as is baccarat at casinos, and kursaals, spas, clubs, and the like. Go to the Town Moor early, and you shall find the sport carried out on most scientific principles, with many pounds depending each chuck on the pitcher's heading or tailing them, and a ring of up to a hundred "punting at the tables" or looking on. I suppose there must be a "fake" in it, because I have noticed the same heads keeping the game going day after day; but, on the face of it, the gambling seems straight enough, and the turnover is something surprising; If you have nothing about you worth "pinching," and can spare the time, you may get plenty of amusement by watching the lads at work, or play, at this diversion. You can also be otherwise accommodated at almost every description of thieving joint imaginable, from the three-card performance down, or up, to the very latest invention in the way of roulette, played with a marble descending "a spinal staircase" after the fashion of ancient lollypop-shop " dolly" machines.

In Flying Fox's year, I actually got excited over the St Leger. Everybody else followed 
suit. "My word and all," as my Yorkshire friends say, it was exciting. Believe me, I did not have a penny on the race, and in my time I have stood to win or lose biggish sums for a poor reporter such as I am, without (so far as I would admit to myself) turning a hair. But this particular contest fastened itself on me, and I should have been a most unhappy man indeed if Flying Fox had been beaten by one of the Yankees. That the Fox would be beaten I never believed for a moment beforehand, but I was a trifle nervous about the start-all manner of things may happen then-and once I was a little disturbed in my innards-viz., when Scintillant, admirably ridden by $\mathrm{F}$. Wood, seemed to me to hold an off-chance of upsetting the favourite. If Jarvis's colt had done that, I wouldn't have minded so much; still, such a turn-up would have been a bit of a shock. What I desired was that Flying Fox might beat Caiman, and, as I say, though I never doubted before the start, nor after it, all the same, I was in a ferment of excitement to which I have been long a stranger, and I do not want any more races like this.

The winner's reception was something truly remarkable. The crowd rose at him. People who pride themselves on not showing excitement, people, too, who had not a bet on the race, cheered, yelled, roared, waved things, threw up their hats, and kept at such vagaries till the Duke's colt was in the paddock. As for the outside crowd, they fairly went off their heads and wanted to take limbs off horse and jockeyin a friendly way, mind you, but they didn't care what they did take so long as they might collar 
some memento of the occasion. Poor Morny, who as a great jockey is by duty bound to pull a long face and look miserable, as if, for instance, he has been most terribly, cruelly deceived by his best friend-that is jockey etiquette after a great victory-found excuse for seeming very cross indeed. The tikes went for Flying Fox's tail and they went for Morny, to pull hairs out of the one and to pull the other right off the saddle by shaking hands, just to show how they admired him and how delighted they were that England had beaten America. Mounted policemenseveral of them-intervened with only partial success, and it was not long odds against horse and rider being chaired into the pesage. But for the police, I am sure the winners would have been carried bodily. Flying Fox stood the attentions quite calmly, otherwise an accident must have been toward. As it was, all ended happily, and amid a storm of cheers the victors landed safely at the weighing-room door, where, as a veracious chronicler, I must record that professional etiquette broke down. What Brer Fox said to himself I do not know. Possibly he was lying low, for sure he wasn't saying nuffing. But the last batch of cheers relaxed Brer Cannon's facial muscles, and, good luck to him, he started to interview Mr Manning with a smile on himBrer Cannon, not Brer Manning-that had to be turned sideways before it could be got through the doorway.

And now let me mention a very peculiar circumstance. As a rule there are three demonstrations-one as the winner passes the judge, another as he makes his way to be weighed. And then one more, a very big one, when "All 
right!" is declared. Morny had to wait to be weighed in while a jockey for the next race weighed out. He passed the scale all right, and I went forthwith to the door to see what sort of a burst of cheering would finish the series. Bless you, the victory had been so thorough and complete that there was no crowd to raise a cheer. The official signaller waved his white banner, but no one took any notice of it except the readymoney bookies, who started, "Pay, pay." All the rest, I suppose, had toddled off to Messrs Spinks's bars. Spinks and Co., of Bradford, are the best and fairest refreshment contractors in England, or, so far as my cosmopolitan experience goes, the best in the world at this game.

As a rule, I do not take very much stock in the old-fashioned-North-Country-fine-sportsman's business. Because a school of Northerners happened to do a great deal of Press work fifty years or more ago, and naturally wrote their own sort up, the world was taught to regard Yorkshire as the true home of racing, and to "make up," the South, particularly that part of it round about the London centre, was written down to balance. One of the striking points was the mighty Yorkshire roar. I am not for a moment denying the 'Tikes' and Bites' ability in the noise-making line; but while holding all due respect for the real champions, the Irishmen, who can do us all at their weight, I fail to see where Yorkshire can beat our Cockney lot. We were, on the Leger day, treated to a very fine roar, shout, or cheer, or what you please to call it, from the moment Sceptre got her pretty head in front a quarter of a mile away from Mr Ford's perch in his judge's box, and a capital staying cheer it was, for it lasted 
till well after an official appeared at the weighingroom door and held aloft a snowy, or, at any rate, whitish banner tied on a stick, an act which is by interpretation, "All right." In the matter of cheering I give credit where credit is due, but let me ask, didn't we poor despised Cockneys let ourselves go a bit when this same Sceptre won the Oaks? A Leger crowd ought to outnumber the gathering collected for the last day of Epsom Summer Meeting, and, no doubt, did beat it considerably; but I very much question whether Sceptre had a bigger reception on her winning race at Doncaster than on Epsom Downs. That St Leger, "my word and all," was worth seeing.

$\mathrm{Mr}$ Coventry came out finely from a most unpromising position, for if ever a little lot did threaten to make a starter wish he or they or both were anywhere else, this company might be taken that way. Kicks were mighty cheap. First one and then another became obstreperous, and more than once there was fair prospect of a general scrimmage. Sceptre on finishing the preliminary canter and being turned round, went for a spin on her own account up to the corner, where, so that people might miss a most interesting part of the fun, the horses used to be hidden for starting purposes. Then when she came back, the young lady did not want to go to the barrier, and was only brought into position at all under protest. Anyone who can cite a better start than $\mathrm{Mr}$ Coventry made when he did let them go beats me, for I never saw anything in the line nearer to perfection. The dozen went together, all with the same leg first, as a sportsman, charmed with the performance, put it, and you could not say 
which led till they began to sort themselves out a bit.

Then Caro did a wonderful thing for a pacemaker. Being put in to make the running for Friar Tuck, he actually went to the front, which, as everybody must know, is most unusual under the circumstances. Off went the Duke of Portland's second string, off and away, offing it to such an extent that when he was abreast of the Rifle Butts he must have been getting on for a hundred yards ahead, and some of us wondered whether he would ever come back to the rest. Come back was the right phrase; he would have to do that to get beaten, because the rest wouldn't think of going after him. For all the good he did Caro might as well have been at Cairo in Egypt or anywhere else, for no earthly connection was established between him and the first horse. No one took the least notice of him, no more than if he had run out. He went on his way, they did likewise, on independent lines. At last Caro was done for and left Friar Tuck at the head of the remainder, that was as the straight was reached. Where was Sceptre? folk asked. She was all right, coming up fast, with Cheers going well. Hereabouts Fowling Piece knocked Cheers's and Cupbearer's chances out, and directly afterwards Sceptre put in a typical piece of work.

Just as she did in the Oaks, the St James's Palace Stakes at Ascot, and the Nassau Stakes at Goodwood, she came and won her race in one act, so to speak. Friar Tuck and Rising Glass were ahead of her. Before you could say " Knife," or “Jack Robinson," or anything else you wouldn't think of saying, she had passed them and settled down to show them what racing 
was like. The rest of the journey was accomplished to a tremendous accompaniment of acclamation. Hardy steadied the mare quite enough, though she had plenty in hand, and won in a canter by three lengths. Rising Glass ran Friar Tuck out of it for second place. Prince Florizel was a respectable fourth. $\mathrm{Mr}$ Bob Sievier, in a tall hat - a very scarce curio at the meeting nowadays-got to the mare's head and led her in, one vast substantial smile. What, the filly? Yes, if you like, and Hardy, too. The crowd hoorayed like mad or blazes-and please that's all, except that femme varie souvent, and down went Sceptre in the Park Hill Stakes on the Friday. The beautiful old poor turf over which the races are held on the moor-or " $t$ ' moor," as it is locally called-always does make good footing. Poor is a word I used advisedly. When you have all manner of self-sown vegetation, each article struggling for life, and very hard, too, against its neighbours, and all squeezed up together without elbow-room-that is how is manufactured the fine, springy carpet to make the best going. "Short" is what folk used to call this, which to a great extent resembles the Down turf. Tons in front of the best that can be done with made courses and seeding. One of the mistakes of the day is preaching about thick coverings of herbage. If you have a covering with plenty of matted roots, you don't want long stuff on top; in fact, the two are inconsistent, and the latter is apt to be very treacherous in wet weather, because the muddy earth works through, and horses slip about on it disastrously. Besides, leaving the grass long hides inequalities, and, I may add, is somehow apt to induce too much 
faith in rollers. Personally, I hate rollers, especially the heavy ones, and wouldn't have one on a gallop of mine, except for use perhaps twice or so in a year. You can safely bet a hundred to one on a track treated by putting men on to see to the hoof-prints and plenty of bush harrowing against the latter-day over-rollered courses. If you want downs spoilt, place a Young England trainer of the Newmarket school in charge of a ground. In a season-more particularly winter-he will probably undo all the good an experienced manager of the old school has effected in years.

Doncaster out of race times strikes the habitual follower of the sport through which the town pays its rates pretty much as does a great public school during vacation, and that to me always seems to suggest somebody's being dead and about to be buried. I don't know why but I never do go through one of our big schools when the boys are away without expecting to hear a bell painfully tolled. If you want to pass an hour or two pleasantly-mind you, the moor makes a very pleasant strolling ground and the avenued high road thereto nice walking, when its great width is left to the local traffic and not guerillaed by wild "course wey" trappers-go fossicking about the old stable-yards on the edge of the town and study the plates on the doors. For instance, past the cross at Bennithorpe, round by the back of the two inns, the Doncaster Arms and the Rockingham, the latter adorned with a portrait of the 1833 Leger winner. There at the portals of boxes and stalls, which in the ordinary way of business shelter any stray nag or harness horse, are fixed the racing-shoes of many great celebrities, with performances painted in between 
the "iron," and if you have a memory these will keep you busy so long as you care to stay, recalling chapters in history, perchance long out of mind till its elbow was jogged in this way. Several times have I lazed away hours visiting old friends' cards-you may almost call them cards-and watching them fight their battles over again. So I have in the Goodwood country, whose villages near the coast are copiously adorned with plates, frequently with colours, too. We do not seem to keep up the custom now. A pretty one it is, though, and a sporting: something in the way of the 'Varsity and other great boat-race winners taking their oars home to hang up and dry, or cutting an old boat up when she really is done with, to make corner cupboards. You would be surprised to find what a great cavernous receptacle a section of an eight does make, and what a useful one, too.

We scarcely make enough of the semi-sentimental side of sport and pastime, more especially of horse-racing, as witness the fact that to only a very small percentage of contests does other than a money-prize attach. I can't help believing that the old style of including plate-or, as the irreverent athlete would say, pots-made towards keeping interest in the game alive. Also, it always has been a fancy of mine to treasure and display memorials of achievements in and about training stables. Achievement is quite the word here to convey my meaning. Surely some sort of good would come if, in the lads' big room, records of the stable's best performances were displayed, if only to give the young 'uns a good conceit of themselves. Personally, I am a firm believer in what the extra-special amateurs, who may be practically 
making a living out of sport by writing about it, condemn so much-viz., getting something to show for your racing. Honour and glory attaching to victory ought to be quite sufficient to satisfy the true-hearted sportsmen. I dare say that is so, though I am wrong made enough never to have felt that way myself. My idea is that you can glorify yourself and be quite honourable enough to pass muster, and at the same time derive a lot of pleasure out of possessing prizes you won. Something of the sort comes in about the ancient racing plates I was talking about just now, and I suppose breaks out in another way with the noble red man's collection of scalps, or the tough's notches on his gun, which is nowadays a pistol. Leaving that unpleasantest side of the question, let me repeat faith in any system which keeps alive memories of a stable's or individual's prowess by means of trophies. I do not suggest carrying the idea to the length of hanging Derby winners' and the like's colours in a church, after the fashion of regimental colours or knight's armour, but we might go some distance on that road and be on the right one.

Now as to the public-house stables and their adornments. Would it be downright stealing if you, being an enthusiast, conveyed some of these plates say, when you came across one, which a great pet of yours wore on the day it did you an extra good turn? Of course, I am quite aware that stealing is stealing even if you take somebody's champagne, not because you want to drink it, but in order to provide yourself with empty bottles to put into his bed-a trick played on the late Colonel North at one Doncaster meeting; but as regards these shoes, you would be helping 
yourself to something you prized very much and which was not valued at all by the present proprietor. On one particular tumble-down door hard by the High Street in Doncaster are half a dozen of the old recorders I covet. No one seems to take notice of them, nobody takes any care of the memorials. I now and then wonder whether it would be any good offering new doors for old, or offering to purchase the ancient stuffy stall. Quite sure am I that opening overtures for buying the plates themselves would be no sort or manner of use, because the price would at once jump right beyond the length of my tether. No sooner do you approach a deal for a fancy article than it soars and soars, and, damn it! it soars, as the Yankee said of the American Eagle when he endeavoured to make a speech. The only way with a chance for you in it is to go to work on the lines of the well-known bric-à-brac dealer who, seeing priceless vases in a house to be let furnished, successfully negotiated purchase of the whole establishment, freehold, furniture, fittings, fixtures, stock, lock, and barrel and all. 


\section{CHAPTER XVIII}

\section{CHESTER AND THE DEE}

THERE is a river of Cheshire which also spends some considerable part of its time in Wales, and there is a river of Oxfordshire which devotes a good deal of its wanderings to making a county boundary or dividing line, and-must I say it?there are salmon in both. Salmon there are, too, in the Dee-to whom you may be introduced in Welsh Wales as the Coed-but not so many salmon as are represented to have come out of it. Of that I am solid sure, because much of the beautiful fish purveyed as grown on the estate does, so to speak, carry a strong Scotch accent, and has Caledonian names on the cases in which it travels. Personally, I don't care where the Chester fishmongers get their salmon, or how they come by it. If you prove to me that it is Dutch, and has been on ice for a week, that will make no difference in my appreciation of the Chester sample as the brightest and most attractive-looking that comes under my notice, and remarkably good to eat. It may be caught, as it used, by the coraclers-patient, persevering toilers, who only need to take off their clothes and sit with a dash of woad on their skins to be 
ancient Britons, which very likely they are in blood. What a body knows is that their goods are there, and do look simply beautiful. If I am asked what I consider the most remarkable features of Chester on the good side, I should not name the Rows first, nor the city walls, nor the Cathedral, but the fishmongers' and poulterers', and greengrocers', who are also fruiterers, stores - their goods are so clean and fresh and well displayed.

For the Thames I always do stick up. I believe that you ought to stick up for your river on the Fatherland principle, and a bit more. But I'll tell you where the Dee beats the Thames, all ends up. Whoever bosses the business there does what the Referee has begged and prayed the Conservancy to do, and wasted its time at that. About the Chester boathouses and along the river's course you find posted plain direction for navigation. There being only a little stream above the weir, no need exists to give the craft going against it the preference, as is only fair with a market current, letting those with the stream come down in the middle and leaving the slack water under the banks to such as have to meet its force. Yet coming down-stream on the Thames you must keep a perpetual look-out, because of the misguided crowd who will make their labour as hard as they possibly can. Dear creatures, they don't know any better. Why should they know at all? No one ever told them, and if they use their wits they are pretty sure to go wrong, because they will follow on the river the rule of the road for horse traffic or the rule of the path for foot passengers. Cyclists are the worst next to the attachés of a 
Thames-side boatyard. If you see a man or men, obviously good scullers, going just wherever they jolly well please, without the slightest regard to their proper course, you can safely bet that they have something to do with a boatyard. If you hit on persons similarly offending, but evidently not workmen, in a boat, you can tell that they are cyclists, and are keeping on the near side of the road. The river would be much more comfortable if the populace were instructed a little as the Referee has begged should be done. Why not post at all the locks and on all the bridges, also occasionally on camp-shedding, simple directions for steering, as do the Chester Town Council or Cheshire County Council or Dee Conservators? Going up, say "they," keep to the right-hand side of the river. Come down on the other, and there you are. If they would add that anyone found guilty of standing up in a boat while it is afloat shall be fined, and no one allowed to get into one at all who cannot produce a certificate of ability to swim, I would rejoice.

Please to understand that in praising the Chester river authorities for publicly notifying the rule of their river's waterway, I do not mean that the same rules ought to be adopted everywhere -only, that whatever the local regulations may be should be publicly shown you. There is another point in which the Dee's traffic-managers score. The river seems to be so well cared for, if you may use the expression. I couldn't help noting the way in which snags and the like were kept cleared, and snags in the Thames are a very sore point with many of us. Somebody ought to see that the banks are free from these dangerous obstructions. On the face of it you would think 
that looking out for them would be part of a riparian owner's duty. I regret to say that in places these proprietors seem pleased if, through a tree's falling or by other cause, navigation near their banks is made dangerous. Anyway, I note places where, as the tree falls into the water, so it lies-at least, the part calculated to do the damage does. The bulk is cut off and removed, but the snag part remains, clearing it being nobody's business except for the unfortunate boating party who discovers it, to his craft's injury. If owners ought to keep their shores clear of such articles, why do not the Conservancy wake them up? Their men know every yard of the river, and could almost make out a catalogue of all standing or fallen trees, bushes, loose camp-shedding, old projecting rails, etc. On these items reports should be made to headquarters, and notices issued accordingly. If the business really lies with the Conservancy itself, that institution would make a large constituency feel grateful if they did their work. It seems impossible to believe that because you happen to own a bit of land fronting the river you are at liberty to let anything you don't want slide into it. For instance, the other day, up Sunbury way, I came on to a lump of concrete which had been a river wall before it was undermined and tumbled into the stream. If the bankholder had not put it where he meant it to be on land, it couldn't have got into the water. He is responsible for its being there, and ought to be made to get it out.

Between art and nature, Chester's river is certainly a comfort and joy. Let me have one of the remarkably pleasant easy-moving skiffs 
from the boatyard of poor Randolph Cook and his still living partner, $\mathrm{Mr}$ Arthur; and let me turn out, not out of the boat, but on to the river early in the morning before the trippers can get afloat, and then you can couple me for selfsatisfaction and indifference to public opinion or anything else with the Miller of the Dee himself. Possibly I might get tired of its scenery, which is well enough in its way, only that the Thames spoils you for it; on the Thames we have flags and fig-wort and tansy, and, for those who know where to look for it, the yellow balsam, and reedy places with sweet-scented rush and osiers, and dabchicks and moorhens and water-rails, and a tern now and then, and pollard willows, as also maiden trees and beech woods, and all manner of delights ; also drawbacks, which I do not discover on my Dee voyages-but, then, you do not always go out to do nothing else but look at the scenery; something is to be said for the exercise, and under certain conditions a reasonable person ought to be satisfied with the diversion he can get even on the Lewes river at low tide-voyaging on low water and Lewes's only product between two walls of mud. On the worst puddle I consider you can work yourself into such a state of sublime satisfaction as to be certain to run into something. You become affected with such supreme admiration of your own performance; being safe from observation, and the boat running well, you reach out just far enough to get a lovely grip of the water, pull the stroke right through, swinging well, and putting on a mighty wrench with the wrists as you feather in the Hanlan style, to make the hoick, so telling with skiff sculling, and flatten your 
shoulders in fashion to satisfy the most precise antediluvian 'Varsity coach. Doing all this or gammoning yourself to that effect, I will defy the devil not to find himself, or fancy himself, just a perfect model of what should be, and at the same time mind his steering too.

It is not easy to go out of your course on the Dee, but Cook and Arthur's confoundedly good skiff did get me into collision and ashore once. If my obstacles had been represented by a weir or a burning bush, it would have been just the same. The ship was so good and the work well set, that, as I say, I was quite longing for someone to come and contemplate so much skill, dexterity, and elegance, when day-dreams of what never was and never would be being realised were so rudely interrupted by a very resistible force, the poor little skiff coming into contact with that immovable body, the coast of Flintshire, and subsequently another substantiality in the shape of the Eccleston Ferry-boat, a trifle only about fifty feet long, painted a bright blue and lying broadside on. I do consider that anyone must be sculling very charmingly indeed to be able to take no notice of this striking feature in the waterscape, although a boy in a dinghy seemed phenomenally fast when I tried to pass him.

Once when owing to recent rains the Dee was liberally provided with flotsam in the shape of trees washed off the banks, it gave me an interesting interlude, because I became a spectator of two good chaps in a boat endeavouring to rescue what they thought was poor me upset, but really was an old willow brought down by the stream. That was an interesting experience, was it not? 
for which my best thanks are due to the two men from the White House who put it all on to get to the supposed wreck and life-save your humble servant. Thank goodness I have not been upset on the Dee yet, except once, and then the derangement was only of a painful mental order. It was like this. For years I had looked at the Dee from many points, and always settled for myself that so far as continuous navigation was concerned voyaging terminated just below the boat rafts. 'Cos why? There was a weir with a biggish fall-at least, always there was when I saw it-and never a lock.

Take it this way. Suppose you came from Chester to the Thames and became almost familiar with Teddington, where was only the weir we all know and no locks at all, wouldn't you conclude quite to your own satisfaction that the weir put a full stop to navigation downwards of the stream? I think you would. At any rate, I satisfied myself at Chester, and never dreamed of being wrong. Now, listen what happens, and tell me whether you would not be upset yourselves. Partner and self go out adouble-sculling on a time schedule-so long to get up to the Iron Bridge against the stream, so much less to come back with it. First part of the programme was carried out all right; second instalment, being entered on, seemed to hang a good bit after a while. "We're going home slower than we came," says the partner. We were so, but how to account for it deponent knowed not. A few minutes later deponent (that's me) didn't feel like accounting for anything except the end of the world, for the pard, in terror-stricken tones, came out with, "Oh, 
Lord! the blessed stream's turned round and is running up the river" ; and so it was, unless we were both stark staring mad. For a bit we were too flabbergasted to do anything except get to the bank in case some tilting up of the world or mighty local upheaval made getting on to land desirable. Nothing seemed to happen, however, so we concluded to at least get back to the hotel if we could and make sure of our portable property, possibly calculated to be of some value under the altered conditions likely to follow water running up-hill to find its own level. When we paddled back to the boatyard, lo and behold! all was pretty much as we left it, and the people about the banks quite happy in their minds, instead of playing the part of supernumeraries in a scene such as Martin, the mad artist, delighted to depict. All was serene, with no evidence of the end of the world being due, except that the river did still run up-hill, and the weir had disappeared-which is to say, the flood tide had risen over it, as was its custom, only we two poor ignorant strangers did not know such a thing could be done, and so funked our lives out, though we didn't say so to each other.

The Dee bore, which did this, is a remarkable sight when it comes in. You see the river as a banked-in stream-way ends at Connah's Quay, some eight miles or so below the city. There it runs out over a vast expanse of flats, which one wonders are not reclaimed, and so out seawards. Over these flats the incoming tide gathers, and in due course forces a volume of water up the channel. At one moment you are by a low tide, which is more just the natural outflow of the stream than the remains of the tidal ebb. The 
next you hear a commotion as of an organised rush, the river swells in height suddenly, little white horses show, coming up where a peaceful ripple slid down. You have the impression of a wild run as of stampeded cattle, or a crowd racing from danger or to attack in a narrow way; waves curl and swirl up the sides of the bank, low water is turned into nearly high water at a stroke, the hurly-burly ceases, giving place to a steady-going, well-mannered flood, and if you are a stranger ignorant of bores and eagres, you rub your eyes and ask whether volcanic disturbances are afloat or visions about. Anyway you must be thankful that as an explorer of strange waters you are not caught napping in navigating in the face of so startling a disturbance, which really is very alarming on the reaches that bend about much,

Poor Randolph Cook I suppose turned out such excellent little skiffs because he knew himself so thoroughly how a boat should feel. In his younger days (and he always seemed to me to decline to grow old) he was one of the finest professional scullers in the country. In his time he coached several of the Oxford College crews, and after a meritorious career on the Thames he went to Chester in order to coach the Royal Chester Rowing Club. To them Mr Cook introduced the Oxford style of rowing, and through his able tuition the club scored many successes. He was the oldest boat-proprietor in Chester, and one of the first to cater for pleasure boating on the Dee. Very much pleasure was he thereby responsible for to myself among countless other river folk.

There is plenty to give a good word to in 
Chester, and a deal of the other sort. Of late I have generally "done" it from the George Hotel at Knutsford-which is Cranford of fame. In itself, Chester - the central city part, I meansuggests cosy snugness, and is not too well off for space in its thoroughfares, especially such main arteries as lead to the Water Gate in the Walls, and so to the Roodee. Now, when in bad weather you get a big crowd, more especially of the sort one experiences at this North-Western racing holiday resort, the comfortable part disappears from the snug idea, and you are more impressed with a sense of being hampered till "bunged up" seems language fully justified. It was while trying to get away from the crowd for a bit that by good chance I made acquaintance with the interiors of some old houses in the quarter which in the long ago represented the west end of a county town that then was to the country-side, for seeing life and town gaiety, what the metropolis is to England. I love these ancient houses-roomy, well, solidly built, for which, so long as quality was assured, expense in moderation was quite a minor consideration-and envy the folk who, mostly with plenty of capital, carried on in them their business or profession on very easy terms, not being above their business except physically in that the ground floor contained the offices, etc., and the proprietor lived in the upper part. Of all places Chester is the one where you find finest specimens of these old county-town mansions. I have qualified as a kind of guide to the city and its objects of interest from the God's Providence House and its ancient carvings to the still more curious samples of antiquity to be found in the small 
curiosity-shop dealers', reproductions of any mortal thing you fancy, of any date you like to mention, produced, like the oil in the widow's cruse, so that everybody can find just one left. From all these I feel inclined to turn nowadays, having pretty well used them up as well as references to Chester in former race times, when the Grosvenor Hotel had a market as big as all our sporting clubs put together, and practically anyone who had sense enough to see that honesty was the best policy could not help making a fortune if his head was screwed on properly.

Chester in a race week does not alter much. You are rushed at not quite so much as formerly by the card and newspaper sellers. To make up, the young savages who rule over passengers in the tramcars are more truculent and brutally overbearing than ever. Old furniture increases within the city boundaries; no age nor colour barred; all can be made while you wait. Plate of various ancient dates, like hope in the human breast, springs eternal in the Chester shops. The food store, the fishmongers', fruiterers', etc., are, if anything, more attractive than ever; the early arrivals, if possible, fuller up than of yore; the local folk not engaged in getting a bit quite up to their best form in looking out of windows at the crowd; tipsters hold possession of street corners, as is their custom; the fair goes as well as could be wished, and the walk round the walls and the look down on the new spring foliage and the fruit-trees' blossom (much more backward and therefore fresher than they would be at this time in May down south) are as good as ever.

I should say that more Welsh folk gather on 
the Roodee for the Chester Cup than are present at any other one time on a racecourse. A somewhat strange similarity between almost-forsaken Derby-Day manners and customs and a certain section of Chester visitors advertises itself stillviz., extravagant get-up by some of the collier companies who make up parties to go to the city by road. An accepted stroke of humour is for men to attire themselves in the other sex's finery, and a good deal of music is brought in ; but as regards that latter, you can bet any odds you like on the Welshmen for harmony on wheels. Nobody needs telling that the Taffies are musical and take a lot of trouble with the art, so that little villages turn out quite goodclass choirs. Unless you are versed in their ways, however, you might wonder somewhat to find freights of passengers by long-backed charà-banc and all manner of carriages, amusing themselves on the way with quite classic pieces. One never gets time enough to "do" such subjects as the setting out and returning home of a colliery village expedition for the Chester Cup. Someone ought to take the business in hand and follow it right through from the first steps towards assembly, generally at the pub. where the carriage is moored, so to speak, waiting for the crew and passengers to go aboard before it can cast off. The muster reminds you a bit of the calling out of a pack of beagles quartered among the hunt's own houses, or-the other way about-of a flock of geese marched home from the feeding grounds and dispersing as their own particular domiciles are neared. They come at all hours-say, from the first opening of the inn-and as they filter to that centre, "take 
something for it," and mostly keep on taking something more for whatever "it" may be till "All aboard" is the order. Why is it that the coal industry goes with taste for high-toned outward adornment? I make no intentional reference here to red hair, which is a presumably natural development where coalfields lie, but have in mind that all-the-world-over miners' taste for hues, like the "just plain red and yaller, hinny," which the collier's wife called for when she wanted something quiet in neckties for her Geordie. Is it that so much of their lives is spent underground, and under grime, that when on the top the pit lads make the most of associating themselves with brightness? 


\section{CHAPTER XIX}

\section{IN DEVONSHIRE}

Devonshire, you say, is a large order. It is, and I only wish I could put it into my pocket, or say just a nice little bit of it on the edge of Dartmoor, for my own use at leisure. Circumstances over which I have no control generally combine to keep from out of my reach all of Devon that cannot handily be reached from Plymouth. I have for many years made Plymouth headquarters at Lockyer's Hotel, and am always glad to be once more at this very excellent establishment.

Always I can do with a spell in Plymouthby going out of it, that is, and it is one of the nicest towns in England to get out of - a remark I intend in its complimentary bearings. If you do not exactly want to clear the town, or three towns for that matter, you can do yourself wellat least, I can-round and about the water part (who can tire of the Hoe?), but should you wish to roam, facilities are great. One of the cheapest ways of spending a week that I know is to treat Plymouth as a centre port or depôt, and go for the excursion coasting trips, etc., which abound on most reasonable terms. Perhaps a cheaper 
way is to work the railways and make for more or less distant towns or villages, according to your ability, with intent to walk back. Give me Dartmoor, if only the edge of it. Grand air it is indeed, and to my taste at its best where you get a smack of the sea as well as the moor's tonic, lung-filling brand. During my stay of ten minutes or so-thanks to the G.W.R.'s splendid service I was able to have two clear days right in Devonshire-I went cattle-ranching to Ranleigh, a place not exactly on the moor, but charmingly moorish in climate, whose proprietor, Mr R. C. Cocks, was justifiably proud of his herds' condition. I like beef, though a stranger to milk, and I know what looks good. Here were the creatures living on the fat of the land and plenty of it, with richest of rich pasture and finest of old hay fit for a racing stable; water laid on for them in every field, also in the byres; the ways about the homestead and sheds all as clean as Mrs Sarah Battle's typical hearth for whist or a Dutch kitchen, no dust nor dirt, never a cobweb, hygiene being preached about the establishment in object-lessons wherever you went, and, what makes always for health in animal life, all dealings with them regulated with clockwork or military punctuality. Who drives fat cattle should himself be fat. I quoted earlier, did I not? Here goes again, because I cannot do better in reference to the hands about the dairy farm. They have good pay-mechanics' rather than hinds'-short hours, and are smart and contented. How do I know they are contented? I found that out very easily. Birdspartridge birds, as poor old Nicholas used to call them-are wonderfully plentiful on the estate. 
That sort of thing is an almost sure guide where much labour is employed and the game is near to a town. Altogether, I was greatly interested in my inspection, although, as I say, I never touch milk and do not as a rule go for cow beef. Still, I would always be content to take my chance with any of the red-coated acquaintances I made on Wednesday. They wouldn't make the sort of cow beef you have to put up with so often in Lancashire, and I may add that you do get very excellent eating in Devonshire out of the bovine sex, where the producers have one fault-viz., killing too young.

At Plymouth South-Western Station, as ever was, I got crowned with a-to me-really novel epithet. The other man called me "a d-d T.G." He wanted to secure the corner seat I picked out for the journey from Plymouth to Waterloo, and made himself very nasty because I wouldn't shift. As matters shaped themselves, we had what the late $\mathrm{Mr}$ Bobby Ryan used to call a "heated alteration." The other man's point was that he always had that seat when he joined the train at Exeter. My contention was on the "J'y suis, j'y reste" lines ; and, being in possession, I, so to speak, prevailed. I wanted to be in a corner facing the line of march, to enjoy the scenery as much as I might. Circumstances over which I have no control-meaning the Editorrequired me to go by a fast train, which I would never do if I were my own master and in no hurry on my own account. Because, you see, I am all for marking and enjoying the views, and while one is being whisked along at $x$ express-miles per hour one misses fair chance of taking in the more or less beautiful features of the land. 
I often wonder why our railway companies do not make a feature of slow-as slow as possible -trains through the picturesque lands they pervade. (Please understand that I am quite aware of the nasty things to be said about certain services and want of pace.) For instance, take a journey to Plymouth by the Great Western and back by the London and South-Western Railway Company. As regards the earlier stages I am blasé, because I have done them so often. But after the Great Western brings me to Exeter I am so interested in the outlook from the carriage window that I count as only a trivial set-off a bit of coal in my eye from the engine's priming. For more years than I care to count have I enjoyed the view between Exeter and Plymouth. So far as Exeter I take things as they come, not being keen except to snatch a glimpse of my old friend Father Thames, who has given me some of the happiest days of my life. But after the Great Western Railway slides away from the Thames Valley, then as far as Exeter, the panorama appeals to me vainly except in its cues. From Didcot to Chippenham I pass stations that are points from which I might preach many discursive sermons. Take Didcot and Swindon, for instance. Around those centres, with leave to wander on to the training-grounds thereabouts, I might hold forth ad infinitum. Chippenham-why, I could talk for a month about the stables handy thereto and the old-timers. I spent many jolly days within those quarters. From Chippenham, you know, you can easily get over to some of the most celebrated stables in the Wiltshire list.

I started, I believe, with a reference to the other man, who called me "a d-d T.G." For 
the moment I did not quite grasp what he meant was to be offensive about the T.G., and, though I am a free and accepted craftsman in a lot of travelling guilds, I was unable for a while to understand how I came to be not only damned but a T.G. It so happened that at the Lockyer I foregathered with an old man on the road. Said commercial gentleman had strayed-as do so many at Plymouth-from his own hotel to dine at the Lockyer, and thanks to him I found correction. "He called you a T.G., did he?" says he, joining in the palaver after the old-fashioned smoking-room style. "He did," says I. "Well, then," says he, "I will tell you what he meant. He affected to take you for a commercial traveller, and, to annoy you, called you a T.G., which is a Travelling Gent., as contrasted with a Travelling Commercial Gentleman."

As to the "T.G.," I only wish I was the right sort of " travelling gent." - the commercial traveller who finds or makes things pleasant. That we have no better friends than the commercial travellers, I know from practical experience. As it is my lot to knock about a good deal, I do get rather envious now and then of brethren commercially travelling, and would like to swop with them. There are, for instance, gentlemen representing houses who run their travellers on quite old-fashioned lines, such as Huntley and Palmer, and Peek, Frean, and Co. These firms' representatives seem to me much to be envied. Sometimes I am almost persuaded to go in and be a "commercial." If anyone is a travelling gentleman, I am that man. You see I am always cutting about the country. As a cutter-about, nothing pleases me better than to happen on a 
real old-fashioned commercial hotel such, for instance, as the White Hart at Spalding. The landlord is mine host not only ex officio but by inclination to welcome his customers as guests. You are not a number, but Mr Somebody, and your little likes and dislikes are remembered and dealt with accordingly. The chambermaid knows about the window being closed or open, and how you want your bath. The waitress tells you what you would like to eat rather than lets you make out a bill of fare for yourself, and the boots not only sees to the booting department, but has at his fingers' ends all details of trains, junctions, excess luggage, and innumerable details useful to the traveller. The young lady at the back recollects your particular vanity, and takes care that letters left over from a former visit are at last delivered.

By way of a change one September, I managed to take a turn at Devonshire steeplechasing, in fulfilment of a promise made to myself a long while ago, and never redeemed though frequently renewed. A great institution is Totnes old-fashioned meeting-"Totnes and Bridgetown Races and Steeplechases," as described on the bill of the play, otherwise card -and one that all right-thinking sportsmen should support and encourage as much as possible. Grand-stands are provided gratis by nature or circumstances unconnected with the executive, and regardless of contributions levied in support of the expenses of the establishment. You can settle yourself in a gratis front seat, or if you happen to make a plural, any number of front seats, on the actual bank of the river, which makes so important a feature in the land- 
scape and the list of obstacles to be negotiated by the jumpers. There you have the advantage of commanding a capital view of the proceedings on the steep hillside, over a loop on which two "rings" are run, or nearly so, in several of the races. You are also conveniently situate for sending to the booths for beer or cyder, and located, too, hard by the section of the Flying Course led round the flat enclosed by the river, the railway and the town side boundary of the meads. An it please you, you may cross by the ferry and ascend the hill up and down which the gees run, and take a comprehensive bird's-eye view of the doings. Say your taste is of a more loftily soaring character, the edge of a great stone quarry right opposite is at your service. Verily at Totnes you can get plenty for your money if you do not want to pay anything at all (that is slightly by way of a bull, but you know what I mean), and be almost as well off if you do care to go in for contributing to the costs of the show, since ring, stand, and paddock must be cheap at six shillings over all. So far I have been writing about the open, as we usually call it in alluding to the free part of a course. There are precious few opens nowadays, except where a pay-box is open too, as a toll-taker not to be dodged. Still, that is only a detail.

Now, please do not misunderstand me. I am fully aware that there are two sides at least to the question as to admitting the public free to witness pastime. All I do now is to cite Totnes as a specimen of a fine old-fashioned affair, which by reason of its openness does an immense amount of good in the cause of sport. Thousands make their way there who would not go to the 
races if they were called upon to pay. If you offered them a gate show instead of what they are accustomed to, you would be without their company, which, after all, is not wholly unprofitable, because they make the value of the sites for booths and bars through their custom. You would also, while getting rid of their patronage, very likely miss their support and sympathy, their votes and influence, when your pet pastime was assailed by the anti-amusement gang. As it is, you lose little that might be collected, strengthen the power of sport in the land, and give the populace opportunity for making holiday-surely a worthy action. I would like some of the reforming folk to pay a visit to the old Devonshire place, whose townsmen will forgive me for chancing on the word "reform." If these folkthe anti lot-did not see much to please them, they must be a poor-hearted crowd. Perhaps all would not accord with their views. That is not the question. The main thing is that these sports, paid for by other people, do vastly please the multitude and lead to no harm fairly chargeable to their account. They have flourished on sportsmanlike lines for years, and I hope will for many more to come.

The stand, I mean not any of the free ones I mentioned earlier, but the wooden one perched on a convenient hillock-side, affords accommodation for I won't say how many hundreds. You do not as a rule associate the flower of a county-of several counties-with presence in a race-stand at four shillings per head. Yet in this cheap affair was an assemblage which few of our swagger courses can beat. Compared to Sandown it was to my thinking, as Canterbury cricket ground in 
the week is to Lord's on a 'Varsity day. Perhaps I am prejudiced, but I always fancy that the ladies on the St Lawrence cricket field beat their sisters at Lord's. To this theory, I am aware admissible objection may be laid, in that so many present at the one are also in evidence at the other venue. But I do not give in farther than to admit that this may be so, and get over the difficulty by contending that those who grace both fields look better at the Kent than the Middlesex ground. As a matter of fact, there were at Totnes many fair patrons of sport who are well known at the "Parks," Ascot, Goodwood, Newmarket, etc. That, as I say, does not alter my case, which is that I never saw a gathering of typical English beauty to beat this one. In this respect Totnes is indeed favoured, and also by the support of all classes. Its racing is not classically great, and naturally, where the accessories are more or less temporary, some of it must be of the rough-and-ready order. But if you ran the Derby, the Ascot Cup, the Grand National, and St Leger here all in one day, the really influential patronage, as evidenced by attendance, might not be stronger. The country-side, also the townsfolk from near and far, could scarcely take more genuine interest, nor would matters pass off better as regards management.

To all readers, whether interested in racing or not, who may be glad of pleasing novelty, I say, go to Totnes. The town is quaint, its church is very interesting (an old friend of mine), the country round is beautiful, not counting the Dart's charms, which have long been recognised as, in Devonian eyes, some good bit in front of anything that the Continent, Rhine and all, can 
show. Some of the pubs. are funny old shops. The Bridge ought to be done, and there are hereabouts reaches of the river which make one want to look up the secretary of the Totnes Rowing Club and borrow a boat on the spot. 


\section{CHAPTER XX}

\section{IN SOMERSET}

WHAT sort of a time have I not been having on a big round in a short spell! Wonderful-is it not? - what you can do if the trains fit in and you are your own master, without appointments to hang you up and prevent your keeping going. Still, talking of engagements, I would be only too happy to make one any time and cancel all others if I might be certain of so charming a day as I found one Wednesday in March, investigating North Somerset. Really, I had almost forgotten what tonic weather was like, when the air does more for you than the second go at a tankard of champagne can-nothing ever did beat the first bite if you wanted it. Such a bright turn had not come my way for when?-why, for "never." The load of dull clouded sky seemed lifted; the breeze nerved one up; the sun was hot, not warm, but downright scorching, burning hot; the sea sent ozone into your system on some wireless telegraphic system of its own; vegetation was stirring-you almost might hear it ; the birds of the air, and the water, too, went about their affairs with a hard-times-comeno-more air of jollity and independence. All 
conditions were enjoyable; you were-anyway, I was-at the same time gifted to appreciate the goods thrown in your way-which is mine-and I thought Burnham a very fine place indeed to pitch your tent in.

Burnham, is, or was, the word right enough, but I suppose that I ought to have sort of broken it to you and not sprung the name without introduction. Let me go back and begin again. In the first place, answering the question, which Burnham? let me explain that my Burnham on this occasion was not anywhere near the Beeches, an old favourite of mine, which I always associate most with the conscientious informant who gave me miles of directions how to make my way thence to Farnham Royal; he made a turn to the right or left of every bend in the winding road. Neither was it the place with the marching wood spoken of by the late $\mathrm{Mr}$ Macbeth, nor Burnham-onCrouch, whence Rule, the old Mr Rule, who used to reign in Maiden lane, in a low-pitched shop of a very small old house, used to procure his most excellent oysters - a shilling half a dozen with bread-and-butter and a glass of stout, was the price I first paid Rule père. Further, I may put out of this argument Burnham Market, a rare healthy corner out King's Lynn way. The Burnham I mean is on the estuary of the Parret and Brue, and away down in Somersetshire, just this side of Bridgwater, and on the sea-edge of Sedgemoor. Now, concerning what I write of holiday notes round about Burnham, Somerset, please understand this: that I was so well disposed towards everybody and everything, because of getting strong air to breathe and bright light down on my eyes, and a hot sun on 
my back, that I could have said kind words of a Black Country spoil bank, or Barking Creek. I admit that I might overdo Burnham's recommendations, but the merit is great.

I did not get there all at once, though I fared well and might have been through earlier if I pleased. Starting from Waterloo for a point on the Bristol Channel seemed to me a queer cut. However, it proved a most excellent way of reaching North Somerset from London, and to me had the advantage of making certain calls en route handy. For one thing, I wanted to take down some ages from a tombstone in Templecombe Churchyard, where is record of a fine staying family. That object I accomplished in hope of the memorandum proving of interest to Refereaders. From the stone, which is, I think, a slate, you find that a couple-Rufus a' Barrow and his wife, Betsy a' Barrow-were interred there, and six of their children. Here is the great record. Rufus a' Barrow, senior, seventyfive years of age; Dame Betsy, eighty-nine. First to go of the next generation was Rufus the second, aged fifty-four ; next one, R. Goddard a' Barrow, sixty-two; followed by Henry, who stopped only one chalk short of the eighty his brother Anthony reached. Last but one went Betsy, who lived a year longer than her mother, and saw her ninety years; while Christian (or Kitty) - was this a son or a daughter? Kit is short for the male Christian-left at ninety-four. Properly advertised facts like these ought to send up the value of building land at Templecombe.

Glastonbury has long been marked by me as a centre for exploring operations, which never have materialised to my satisfaction. Still, I managed 
to sample the place at a run, so to speak, and, at any rate, did the Tor, with its church-tower remnant of the fine edifice said to have been destroyed by an earthquake, and a carving of the devil trying to beat St Michael in a weighing match by putting his foot on the scale. Further, I visited the George-I could not do the Abbey properly and the inn also (formerly, according to tradition, a house of call for Joseph of Arimathea and Henry VIII.), so the former was remandedand inspected Glastonbury thorns, which had bloomed this-i.e., last-Christmas. The wet season beat me this time from getting into the peat country, which is not exactly like any I ever visited before in Ireland, France, or the Eastern Counties fenlands. Weird to come upon as a stranger are the tracts of land where the turfs are cut and stacked in conical "houses" such as children build with boxes of bricks, and after a fashion like to giant chocolate-coloured bee-skeps. The country talks to you whole libraries about Arthur and Alfred and the Norman swells, among them Robert of Lewes, one of the De Warrennes, who did Wells a lot of good; Monmouth, who did it a lot of harm, and Sir Walter Besant, the best chronicler of that pretender's mishegotten campaign; and it suggests that, for the benefit of succeeding generations, adding a second Van Houten to cope with these West-country fens would be extremely useful, since for all the oldworld glamour ague and such ought to be anachronisms when you know what brings them. However, give me the place as it is in ordinary years before it has been altered or reclaimed further, or done anything to or with, as one in which to spend a happy week or two. 
From Glastonbury I made to Wells, a rare nice city or town. Wells has water, good water, heaping itself up at the springs and running over. Also it has the Mendip Hills, inviting you to climb into the keen air from the Atlantic. Wells has one excellent hotel, the Swan, and maybe more, and a big square, on which the Bishop's or cathedral close makes. Clean it is all over, fresh and smart are its lads and lassies-the latter with complexions no town would allow long, and the former a rolling mouthful kind of pronunciation rather than accent, at first striking you as laboured affectation. Elbow-room and lots of it is apparently cheap and indisputably plenty in Wells. Flowers grow about the town as if smoke was an unknown quantity; trees as if too many of them had been committed to the care of barbers instead of masters of woodcraft, for they seem to pollard or poll every sort. There is reason in all things. What, I wonder, is the one for pollarding elms, beeches, oaks, limes, ashes, poplars, willows, larches, and alders, when they do so well left to carry up maiden growth. Whatever may be the justification for the method, you do see it illustrated somewhat extravagantly. For instance, take the line of elms by the moat of my Lord Bishop's Palace next door to the Cathedral. I scarcely dare get nearer than next door to Wells Cathedral, for I must be on to Burnham, and you want a week to do the Minster, more by token that the guide-books are good and the grand architecture appeals to even a novice. Then there is the wonderful clock, with its men in armour outside who strike the quarters and hours, the Jack who sits up in a corner and kicks the strikers with his spurred heels, and the mounted knights who run 
a tilt at each other, with result that one is unseated in sight of onlookers, but put up again " off."

Rowing men will find a couple of memorials to carry them back to the eighties. A very beautiful window with the Eton arms and motto and New College, Oxford's Wykeham's “Manners maketh the man," is to the memory of the fine oarsman Douglas M'Lean, who died of enteric during the South African war, and an Ionian cross close to the cloisters to his brother Hector, who succumbed to typhus in I888. Sixteen years ago, can it be? It seems more like five or six since the two stalwart, Colonial-bred Scotch lads--Hector was only twenty-four at his deathwere mighty men in a boat, while all the while each a picture to the life of $\mathrm{Mr}$ Verdant Green, spectacles and all.

Burnham I like much, though I can't quite understand a breeze coming straight there from its next-door neighbour over the way, New York, being bracing. Bracing it is, though, as the Queen's Hotel testifies through the bills of fare provided by its proprietress, whose husband was first to patent an advance specimen of the cricket scoring-boards now in use in various forms. If claims had to be heard for this I should put in one myself, and not expect to be beaten-but that by the way. Overnight I made up my mind not to take the village or town, because I had not been there three minutes before I came across a Kensit Wycliffe sympathiser haranguing a collection mostly of small boys on the Englishman's rights to kick up a bobbery in church. Such privilege may be one of our most precious heritages for what I know, only I didn't go to North 
Somerset's sea or river board to hear bobberies kicked up at second-hand on the shore, however profitable the Kensit agent in advance may find it to be alternately jeered at and cheered by the young 'uns. However, the party was "off" in the morning, and the loveliest day on-just what you get in Norway and Sweden before winter goes, but after the sun gets power to assert himself between the night's frosts. The town is like bits of a score of seaside resorts made into patchwork-all of good materials, mark you. The air is Lowestoft or Redcar; the dunes or denes might be borrowed from Southport, Walcheren, Rossall, Rye, or Yarmouth, or, for that matter, 'Frisco. No other coast-line of my acquaintance has quite such good sands. I wonder these have not been found out for training when frost grips turf gallops. The natives of seagoing persuasions are-as West-country watermen-fishers almost invariably are-kind-hearted, respectful, self-respecting, plucky, strong chaps, who have put up with much ill-luck quite heroically; and the rural country hands amiable, hard workers well affected to the stranger.

While difference between these two classes displays itself automatically, you can hardly tell quite where their spheres of usefulness should begin or leave off. Sometimes it appears to be the sea encroaching on the land, to the lord of the manor's loss. Mostly the Crown or the Admiralty has strong reason to call in the aid of the law to restrain the land from going out to sea and staying there on top. Meanwhile, pace local observers, the denes grow, making a bigger barrier between the water and the low-lying peat country stretching over by the moors to Glaston- 
bury. Stone, hard and lasting, is cheap in the district, and the bricks a credit to the country. Houses crop up somehow, increase and multiply, with plenty of space allowed; the more building is done, so much the greater range is devoted to golf links, than which none more sporting. Golfers may come, and houses be built for them, also other good judges, visitors who recognise advantages when they see them. The country behind the denes is unaffected, and not to say for a moment spoilt. The wild birds of the littoral seem to care no more than the mosses and stone crop, the sedge and the short turf, bonds and weights to nail the sand where it settles after working up from the sea. Listening to them made half a whole holiday, to the birds I meanthe sheldrakes and the sandpipers, the gulls and the brent-geese, the ordinary wild ducks, and the curlews, apparently sentinels on duty for the whole army of what shall we call it, millions, well, tens of thousands. Larks do not, I believe, go out to sea for the purposes of singing competitions. Still, the Burnham larks, by name legion, were hard at it, at any rate within earshot, when I was half a mile from the shore-line trying to catch the shell-ducks napping so as to mark their bright-coloured trimmings. Many took flight and settled before my eyes, ideal embodiments of fancy flying dragons "sketched" by myriads of sandpipers playing follow my leader, after the manner of their kind, to an accompaniment of sharp shivery whisperings as the flock's wings cut the air.

If you go walking at Burnham, please understand need for choosing between occupations and sticking to one. Golf on the most sporting course 
will occupy your attention sufficiently without attending to the world beyond the denes, so will going along them for the non-playing pedestrian. If aquatically inclined, make for the fine hard sand to take observations; and if you can walk, go ahead laterally, I mean not over towards Cardiff, but, as with me, straightway till through the haze looms a mighty barrier, a last link of the Mendip Hills, a spur without a principal to buttress up, cut off from the range by the estuary of the Axe, across whose waters is Weston-superMare.

Brean Hill I believe this peninsula is calledand a grand view you get from its back when you have mounted, only it wants a bit of mounting. A fort is up on the high ridge, but a long way out of sight. Not a soul did I find, though evidences of civilisation were apparent in the shape of an empty beer-jar and a tin house. You could not miss your way there, though without the services of a guide, because the sea told you very plainly not to go to the right or left, and in my case appetite set up a big finger-post lettered to the Queen's Hotel, a hint I took more sharper and more by token that I had to call at the-how did the Sussex man describe a house the other day, four square bobblewise, I think he said-Burnham Church, with its leaning tower, made of an enduring stone, now adorned by a slab let in to commemorate its jubilee restoration. The slab, I may mention, is crumbling already on its face. Fain would I have extended my holiday stay and tour, but the full day cribbable was running itself out, and I must make acquaintance with Cheddar's cliffs before getting back to business. Is it irreverent to admit that, liking the pickles, I 
resolved to try the sauce again? One turn up that hilly pass between the great crags settled me. I don't mean that I was settled by the climb on the road, please understand. You do not catch cliff-climbing beat me, because it did not, though in places the wind attacking you in between the sky-high walls played on and twisted you about like a stream of water from a steam fire-hose. What I do mean is that finding twenty-four hours barely sufficient to combine perfect rest with doing properly the places and the travels hereinbefore mentioned, I was settled by Cheddar's charms in resolution to explore the district systematically and at lower pressure. 


\section{CHAPTER XXI}

IN AND ABOUT BATH

I GO to Bath more, in short, to go to Bath than for the racing there the last week in May. I am always discontented while doing the meeting, because I vastly prefer being in the town and fossicking about the shops and the grounds to trudging or being lugged up the dreadfully long hill to the course, with certainty of being smothered and choked by dust on the out journey, and a quite promising chance of a smash on the downward. At no other place can you find such attractive shops. Surely this must be a rare good settlement for sensible people, who like to see what is for sale and buy for themselves, instead of leaving the catering to others. The best of everything appears to me to come to this mart, and is turned over at most reasonable rates. A prettier show than a well-dressed fruiterer's shop window makes is difficult to name. All the Bath shops are well dressed, everything is so clean and bright that you feel inclined to order the stock en bloc. London is all very well in its way, but for pleasure in shopping give me Bath. Where do the linen-drapers (are they linen-drapers where the dresses are sold?) or the haberdashers 
--thank goodness! I do know what a haberdasher (word of reproach in "Pickwick") is-display so much taste (not in London) or the furniture people collect so skilfully? The tailors, London swell builders, make a merit of aping banks or government offices and appearing as privatehousey as possible, instead of using the natural advantages attaching to window frontage in an expensive situation. Inside you can view their treasures, in a bad light. Bath does give you a show in the front of the house as well as inside. What with one trade and another's exhibits, I can always amuse myself well for a day or two, only I do not get the days.

Bath's personality lets it change in the times, but scarcely with them.| It holds still, from the Georgian period, its strong individuality as a centre to which people with money to spend and no apparent necessity to work and earn it resort, a haven for valetudinarians, a county town where "county" really does mean something of more than merely geographical significance, and society is apt to be exclusive, not to say stuck-up, or - shall we say?-sufficiently conscious of its own importance. About the place hangs a strong flavour of the Spa days during our inland watering-places' long, big innings, scarcely to be understanded of the present young generation, who cannot quite make out how a watering-place can be so at all without a seashore, the sea with it, and, equally important, a pier. Structurally the Fair City has altered very little, I fancy, from its Beau Nash days, because the cheapest building material is stone, and that naturally lends itself to the old-style scheme, adopted from the beginning of fashion's catching 
on to the town. Socially, Bath has sobered down, and now does not at all strike one as a rendezvous for going the pace. But it always reminds me of "the Old 'Un," Charles Dickens, and of the Inimitable's sketch, a highly-finished one-no, not of the Pickwickians, $\mathrm{Mr}$ Weller, the footmen, and the swarry, but of another fine wordpicture-Flora, of "Little Dorrit," the voluble and amiable relict of $\mathrm{Mr} \mathrm{F}$., with whom gout flying upwards soared to higher spheres. Look up your "Little Dorrit," good readers, turn to the description of married life as not romance but solid comfort with any little thing, such as early lamb or asparagus, thrown in. That is the way Bath appeals to me viewed through the windows of the excellent York House Hotel, or Fortt's, best of restaurateurs. Fortt's at Bath and Parker's at Manchester, with Booth's (Fortt's uncle) at Birmingham, are three firms to remember.

I have pleasant memories, which cannot be too often revived, of most localities indicated by the stations on the Bath line. Glimpses of the Thames, Loddon, and Kennet I find refreshing, and so are peeps at the high downlands all the way down before Didcot, right on to past Chippenham. A great help to filling yourself from bottled-up stores of pleasant outings is to know the highroad as well as the railroad, and in seeking such knowledge I have, I am glad to say, been ever diligent, finding always due reward therefor. Perhaps being still inclined that way accounts for my making the worst of Bath meeting to myself, and going fossicking on the line of march instead of haunting the racecourse.

The end of May is a good time for the 
tramper-a countryman at heart, however, he may appear to the metropolitan cabby, who, taking him for a yokel, wishes to charge him accordingly. A backward season is, I am afraid, the nation's loss. To anyone unable to gad about earlier, and who has missed the proper spring effects but is free to range now, it can count as gain. In most years the country-side, though beautiful entirely in summer, falls short in variety of late spring's tone, for as foliage develops towards maturity your view becomes more limited, although, perhaps, greater selection of detail offers. In the leafy month of June you arrive at a stage when you can't see the wood for the trees or the trees for the woods, and individuality of colour and shade is far less marked than earlier. An oak is in ripe summer pretty much an oak, though gradations from olive to apple-green do count. Certainly, then, the faithful painter might catalogue a many shades, according to soil's and weather's tinges, but give me the real spring budding leaf ere rough gale or scorching sun has staled or even adolescent age can wither its infinite variety. When the primroses are nearly over, but not done with by any means, and the cowslips are long in the stalk, the bluebells rich in blue, and the wood anemones having their innings; when the buttercups gild the meadows with glow, deluding you into thinking the sun shines, while delightful "growing rain" is Scotch-misting you into rheumatism, that is the time. Then the speedwell makes brilliant sapphire patches; the green money is throwing up its flower stalks; and the orchids $-I$ call them orchids, bother whether they are orchises or not-are beginning 
to come on ; the spring flower, as the Welsh call marsh marigolds, are steadily staying; and the dog violets and wood sorrels are flourishing; the laurels are thick with bloom; the forest trees mostly thick with blossoms; the old sombre green branches of the spruces are tipped with dainty green; the larches' spines are tenderly new ; the limes' leaf-bud's sheaths thickly strew the ground; and all manner of humble flowers are at their best; such as our white and yellow nettles, and that sort.

Then, friends, is the season of the year when comes my delight on a shiny or eke a rainy day. All is fresh and delicate to soothe the eye. Talking of humble flowers, I went into a little church down Sceptre-I mean Shrewton-way, and found it-the church, not Sceptre-decorated profusely with the wild spring flowers just noted, and very beautiful the effect was. They were sheep-washing down the way which was mine pro tem., and a Bedfordshire farmer, an emigrant to these Wessex parts, told me a yarn about his grandfather and wool, showing that John Bull can be obstinate sometimes. "When the old gentleman died," says my newly-made friend, who drove thirty miles to do me a turn, "he had tons and tons of tods put away, some for forty years. In all that time not a fleece would he sell because the price didn't suit him, and for lots of it which fetched under sixpence he had refused half a crown."

The oaks provided more changes of brown than you could find in all the paint-boxes ever turned out, unless you did a power of skilful blending of burnt umber, sepia, chrome, and the vandyke which in scenery serves all purposes 
from indicating your subject to scumbling in your background. Just right they were, with pendent bloom tassels a long way ahead of the ash, for the most part hardly sprouting, and many frost-nipped in the bud at that, as are the walnuts, ever deliberate in putting forth their shoots. The oak is before the ash this year, and, no mistake, a good winner, but in a terribly slow race. These two have been muddling on while the grass has been making hay or getting along so, sunshine or not; and talking of oaks, we will cut the rural rides cackle. No more words from me about the parks and the cottage gardens, the grey-green down hills and the water meadows, the old stone houses, and the cool cots; also the cider, which goes better in higher temperature; the nests and the fledglings with scolding parents, who had much better keep their mouths shut and not cry out before the youngsters are hurt, because all their nagging only gives the whereabouts away; the cock pheasants cavorting and showing off to distract the attention of their or somebody else's - they don't care whose or which -good ladies full of household cares with roving families; the jack herons all going to bed at the same time, and their spouses; the wild duck, who must make a splutter when bysie hour falls; and the moorhens, who, male and female, would be old-maidishly consequential in face of a midnight earthquake; the butcher birds and their larders ; the blackbirds and thrushes, who must look ahead to a plentiful diet of worms-they seem so glad because of rain; the larks in heaven's gate, and the little dabchicks, under the water when you look for them ; the golden gorse, marvellously full of evidence that kissing is in season, and the 
broom, which can make as brave a show now and stand three times as much frost as can furze in winter.

Admiral Nelson, K.C.B., he stayed in Bath once-there is the house, and there is the tablet on it, alive to witness. Fossicking in Bath's ancient crony, Bradford-on-Avon, I very nearly bought Lord Nelson for a dollar. $\mathrm{He}$ was on offer at the price. Now, I ought to have made more than five shillings out of faking up a yarn with the purchaser of the relic (made while you wait)-not your humble servant, but a British Jack Tar all "belayings" and "avastings" and "slack hoistings" with a pigtail at the back of his head, a quid of pigtail baccy in the front of it, a rolling gait, and breeches a foot wider over the toes than on the knee. Jack, naturally, seeing Admiral No. "one hundred and eleven" on sale in Staffordshire ware for a crown, with a beautiful blue uniform, a sprigged satin waistcoat, white silk stockings, three-cornered hat, and wig, also the regulation number of ones-one eye, one arm and one telescope under the surviving wingmust in the story to be written be indignant. Then would he proceed to terrify the shopkeeper with strong salt-sea-seasoned oaths into charging him a guinea-not a farthing less-for the Admiral's effigy in Staffordshire ware, a really excellent fairing, and convoy him off to partake of much punch and toast drinking. There is the scheme all ready. I am too truthful. I couldn't "make up" like that. So also is Mr Pyke, of Bradford-on-Avon, furniture dealer, too truthfulat least, for the second-hand branch of that trade. "The Admiral seems very cheap at five shillings," said I. "I am not selling you this except as 
modern," he explained. Now wasn't that honest? Phenomenally so, I think. "This," a very clever replica of the old fairing, would take in anyone except a real expert, and is now made by the thousand weekly on purpose to deceive. I thought I would mention Mr Pyke to favourable notice. You don't often come across a sort like this.

What do you say to a smart, sharp little silky Yorkshire terrier making believe to manage a herd of dairy cows, just for all the world as if he was a drover's dog brought up to the business and put in command? You wouldn't stand that yarn, would you, unless you saw the creature acting as described? Quite natural, too, to be doubtful. Still, I assure you, I did meet with the tike, and a good tiny sportsman chap he is too, who could live comfortably with a large quart pot for his kennel. That was at Freshford, between Bradford and Bath, about where the Avon is joined by the Frome, and is so very pretty. For the matter of that, so is the canal, which I recommend to entomologists as a profitable hunting-ground. Always a beautiful stretch of country, this Avon valley is particularly attractive with the fruit trees and the forest trees in flower, everything brand new and free from all mark of wear, and the meadows and woods carpeted with flowers. I should have lost badly over said blossoms had anyone taken me on and offered to bet I did not name what made a bank white by the acre. Wood anemones, I should have said, and bet, too. But nary an anemone was there, only "ramson" by the acre. Though pretty to look at, this is not so nice all round, seeing that the stem smells about twice as strong of onion as garlic can. 


\section{CHAPTER XXII}

ASCOT AND NEWBURY

"Aristocratic Ascot" was a line we used to see on the sporting papers' contents bills. "Indents," "cross-heads," and the like were not then in use as finger-posts to guide the reading traveller to different stations on his journey through the long columns; and if you wanted to know what was being written about, you had to wade through the lot or on towards that way, or refer to the "bill." "Aristocratic Ascot" the late $\mathrm{Mr}$ Henry Feist (Hotspur II., his brother was the first) christened the Royal meeting, partly out of desire to achieve alliteration, also because of truthful aptness which was not quite so discoverable in 'Appy 'Ampton or Glorious Goodwood-two other little bits of nomenclature for which $\mathrm{Mr}$ Feist was, I believe, responsible. Curiously enough, the first is a singularly smart bit of naming, for while what is, or passes for, aristocratic certainly gives the racing a tone, that same is the note of the neighbourhood, the one the locality desires to strike and impress on you. To take the village- "city and suburbs," the people of the country call it-as its denizens desire the place should be taken, you must not go 
there during the rush and turmoil of its sporting week, when, though great personages are plentiful, so are the middling, and even less distinguished, whom extreme nobility might class as common, and the unmistakably undesirable, who are a class with no class at all, poor creatures. No; to give the settlement a fair chance of doing itself justice in your eyes, you should occur in the quite off-season, when racing is out and hunting is in, and some greatness has got up a bazaar or a concert at the Grand Stand, or a dance is on.

Then, also on the arrival of the fast afternoon after-business train, you get to understand what Ascot's proper form is according to its own estimate. If smartness and neatness and the pride said to ape humility - who shall wish to go scatheless if this is a fair impeachment?whose outward and visible sign is most precious, evidenced as it is in everything being as good as can be without evidence of flashness-are indications of the aristocratic, then Ascot is O.K. If keeping houses and grounds in apple-pie order, driving and riding good horses, and, generally speaking, going about as if you enjoyed life and could afford to pay for the privilege, is in the aristocratic line, again O.K. is the word for Ascot-or are the lecters. And the roads! Old as I am, obese as I am, broken down all round, and standing over at the knees, with a touch in the wind, and all the rest of the little afflictions which do not permit of your passing the vet., though they do allow of your doing a hard day's work seven days a week; crock that I am, I declare that I scarcely ever get on Ascot's highways in fine weather without wanting to 
break into a canter instead of walking. Find me a better word than aristocratic, and I will make it complimentary to the sand-topped roads round about this centre of Berkshire. One day in the middle of January I bested the railway company in the only safe way not involving original-no, not sin-outlay for carriage, and toddled over from Windsor to Ascot and back, and was very glad I did. I wonder whether the King has got a new road-mender-in-waiting. Either he has, or the old one has improved, for the going through the park was excellent indeed; and so it was in the forest and right on to the Royal Hotel, to reach which one passes the Crispin, well beknown to the Great Western Railway Company's passengers for the meeting.

The light was not so bad for an early January afternoon. You could scarcely desire a better roadway. There were the birds having a last word before going to bed, and the deer marching about in what always seems to me as rather the manner of superior beings and in aggressive "tone of voice." As the day darkened among the forest trees the great old pollard oaks looked more ancient, time-worn, and altogether interesting than by full light; the owls had begun saying their say before the jackdaws had finished (these blacks never do finish, and, I believe, talk in their sleep too); you could hear the small deer rustling in the dry leaves if you could not see them; the cock pheasants had something to go crock, crock, crocking about (a discontented vocalist is your pheasant all the world over); partridges were carrying on companionable-like, as if already thinking of setting up housekeeping; a stray rabbit or two was out and 
about, and now and then you might spot a hare whisking across the road. Plenty there was to amuse a body who kept a look-out, but in five miles I don't fancy there were five people on the line of march to be amused. On the return journey, by daylight, only a few more were discoverable-say, five to the mile, counting the road-menders.

Ascot being a name hardly anybody hears without some interest, and its sylvan approaches - there are several, you know, through Windsor Parks and Forest, good going and pretty-it would be an appropriate spot to hold classes in the walkers' college for which I have such a fine scheme (which will never be brought out). It will include various side-show branches, all of them carrying nice pickings attaching. The nation will run the college, with yours truly as boss, and I will see to the branches where the money is to be made easily on my own account. Among these supplements will be the guide department, and others calculated to pay are the equipment and remedial bureaus. When anything special is on, also when there is not, our college will supply the public, or at least I will, with qualified perambulating instructors to personally conduct parties to and from the scene of action, if there be any action, otherwise with the simple object of going there and back. The college (which I mean to say myself) will put the conducted in the way of purchasing our brand of coats and hats, and collars, ties, waistcoats, jerseys, shirts, socks, and all-never a cap, mark you. Caps are the worst invention ever created to keep your head hot and thin your hair down. The College Patent Foot Preparer, also 
the Chafe Preventer, another proprietary article, the Catch-cold Obviator, and the Lissomness Assurer will be at pupils' service, and so will a whole library of route books, teeming with information in bright, newsy form and heavy with advertisements. Altogether we shall, if we strike while the iron is hot, pretty well make our fortunes-one of us will, your humble servant. For the populace has been so freely informed of late that it can walk if it likes-the information coming for the most part from people who manifestly never could walk themselves-that a fine market was open.

Speaking seriously, there is the making of a pleasantly earned income out of taking up the walking guide business professionally. I wonder how many answers I should have received to an advertisement offering to personally conduct eligible parties from, say, Datchet to Ascot and back during the race week. Of course, you must chance the weather, and might have bad luck; but, given good, "what larx," and what a time the talker can have letting off his local lore! Once I had the pleasure and honour of taking our Editor over some of the ground-bossing a class of one. We didn't go the shortest way, but did ourselves well, beginning at Datchet churchyard's smith's tomb, showing in miniature all the implements of the farrier's trade. The church lasted us a long way, because of a beautiful gipsy funeral I saw there once, and the strange doings of the tribe, which, as my class had not heard, I related to him, including the affecting anecdote of West Drayton's burned Grand Stand and the coup manqué. We had, I recollect, to hold over for a mile or two the 
history of Datchet's wooden bridge, carried away in a flood, and Datchet Ferry, with consequent right-of-way across the Home Park to Windsor, carried away by Act of something when the railways were permitted to make entrance into Royal Windsor, and the public were given with one hand a great deal which was promptly taken back by the other. If I remember rightly we nearly allowed ourselves to stray off on to the towpath along to the Bells of Ousely-locally corrupted into Boozely-but were kept in the right way by prospect of calling at the little house on the left opposite the Royal Gardens, where at that time the connection was almost as much French as English. A queer little colony settled in Old Windsor, having to do with Queen Victoria's tapestry works. Capital fellows, very fond of fishing and not bad at boating, were the men for whose behoof all manner of foreign drinkables and eatables were introduced into the tiny village. For instance, at the small pub. you found staple articles of refreshment in vermouth, cassis, claret vended as Bordeaux, coffee on hand at very short notice, and the constant smell of stale cigarettes that qualifies the French cabaret.

Instead of bearing up to the Union gate and edging across, so as to leave the Copper Horse, who looks out from the crown of the Long Walk, we for a particular reason trudged straight on up Priest's Hill in order to interview the herd of wild boars and other undomesticated porcines preserved in a compound for table purposes. I don't like wild boars, except to eat, and am always half-afraid of a big old domesticated pig. What couldn't a weighty farmyard creature of 
this sort do with its tremendous jaws if it pleased to go at you? Besides, I once was all alone in a great German forest-one vast wild piggery -with nothing but slippery barked beech-trees two or three feet through, and thirty up to the first semblance of a branch.

We cut across to the White Lodge and the charming little church hard by, and then down the hill and over to Sawyer's Gate, making company then with the crowd who had padded it up Queen Anne's Ride, the shortest, or, as a Yorkshireman would say, the gainest way from Windsor. You come out a little distance from the starting end of the Royal Hunt Cup course's alleged mile. My word! what a hot day it was that we did this walk, one of a whole row to be mapped out in getting from Datchet to the Grand Stand. Ascot week is by no means always hot-nor dry. I have had many a drenching on homeward journeys from the Royal Heath. Which year was it I got wet to the bone crossing the park from Sawyer's Gate to the Union-another of the great chase's entrances and exits? Curious, is it not, that close to the latter, which no doubt derives its title from proximity to Old Windsor Workhouse (which, I may once again repeat, is a beautiful Queen-Anne-baronial-hall sort of structure, designed by the late Sir Gilbert Scott, who only beat the late Judge Clark by a head after a dead-heat in competition for the job) is a near neighbour to a "Union" pub., another styled the Oxford Blue, which between them give the locality a strong'Varsity flavour? Let me explain that our college (which is to be) would not grumble at the temperature being low for our 
outward journey to Ascot, or anywhere else, with the walking pupils, because it is a great and desirable thing to avoid getting really warm on your way to a halting-place unless you are going to change, as well as dwell there. New hands put it on to finish a walk, but that is a very bad plan if you are going to stand about.

Perhaps you may inquire what I would substitute for the unwholesome cap. Precisely the headgear associated with Ascot races-the topper of Society. People run down the stove-pipe. I would never put anything else on-as headgear, please understand; I do not intend anything in the Lo the Poor Indian line-if I could arrange things my own way. First, because I consider it the most comfortable wear; second, on account of its being the cheapest, and it is wonderful how sensitive most of us are about the article. One of the oldest Covent Garden Market stories is of a much-respected salesman who, while the big blaze of the theatre was on, found himself in a dense crowd, and a tall hat, with all the morning's takings in his clothes, and some pickpockets of his acquaintance for nextdoor neighbours. They knew about his money, and he knew they meant getting it, so kept his hands fast in the pockets where the gear was. All manner of dodges did they try. Such friendly pleasantries as flicking his ears with their finger-nails and grinding his toes with their boots did they inflict. He stood that, and the money was safe. They bunted him in the small of the back with their knees and pinched him in the soft places. So much in the way of physical torture he endured manfully, and held the bank all right. Then they called him names and said 
spitefully libellous things of him and his relations -things to which the Eastern "May dogs defile the grave of his grandmother" were courtly compliments. If anything would make a man "put 'em up," the marauders' remarks must ; but poor chap, he couldn't put 'em up without taking them out of his pockets, and the wickeder became their persecution the more determined was he to stick to his stuff. Alas! though practically armour-plated nearly all over, there was the one weak spot by which the whole strength of anything is to be gauged. Figuratively speaking, and without regard to anatomical accuracy, he had an Achilles' heel on the top of his head, with fiendish malignity one of the bandits turned his smoking, juicy quid out and gave his prey to understand what he meant doing with it, and that was to dab it on the top of the tall hat. They could, and did, pay into his tender parts, corporeally and cruelly lacerate his inward feelings without moving him from his line of defence. Having his faith, also the fair fame of his female family, assailed had been nearly, but not quite, enough to rouse the British Lion, but the quid put the finishing touch. If anything should be sacred the silk hat must. Out came his hands to defend the cadey; in went the prigs'. In saving his hat he lost every shilling of his money.

With everything up to date at Newbury Races, I have been much struck by an unaccustomed sensation of old-fashionedness over all. Further, something seemed to be missing to fit in with the mysterious impression that this was not a new but a very old going concern. Walking to and from the course from Newbury I 
found explanation. Within the town you came on a class drawn by the races, people whom you seldom meet on occasions like this, knowing enough on sporting matters in their way, but not bearing the usual stamp of the accus-tomed racegoer. They filled all the inns as on an extra-special market day with no business to do, except eat, drink, and be merry, and thronged the streets, a very large proportion on wheels. From all quarters they came, as you might find out by getting about on the roads a few miles out, where the "half-way houses" along long lines did rare trade, both with going and returning wayfarers. On all hands you heard great rejoicing that "we" were going to have races now, and make no mistake about it, the folk of the district have only just now had supply put on to cope with a long-established demand. Putting out Newmarket, Doncaster, and one or two other towns where meetings are held, I should say that few benefited more in their trade through a fixture than did Newbury, which was singularly free from the predatory and cadging fraternity. The solution of the puzzle as to a sort of anachronistic inconsistency came after a bit, in that this was an old-fashioned meeting held on modern lines. To make it complete you wanted a fair out in the open. I did not want anything of the sort, I only speak of it as an accessory to carry out the idea inducted. The folk over the way were the very stamp who brought off a double event, with racing one and the fun of the fair another. And in the higher grades of the attendance you found here, there, and everywhere representatives of the class who used to do the local races as a 
matter of course, if not absolutely of duty, whose carriages were always expected to be there, and whose patronage was advertised in the days when Town and Trade subscribed for a town plate, the licensed victuallers put their little backs together and endowed a race named after the Trade, and you supported a meeting by subscribing to the fund, also partaking of the benefits of the Race dinner, in whose interests were run "Claret" and "Champagne" Stakes, whereof the winners were bound to furnish so many dozens of each for the race subscribers' delectation.

Unless you knew the district, you would scarcely believe what a lot of interest villagers in these parts take in horse-racing. Yorkshire is supposed to talk horse. I should stand on the back blocks of Berkshire against the Tikes or the Bites for interest in the Turf. Great believers they appear to be in touts' tips, and are, I guess, fine customers in their way to the local s.p. merchants, not above taking small bets at a time. Certainly they get enough certain winners for a single race given them to last through a three days meeting. I suppose this is because there are so many stables handy. Anyway, they all seem to know a powerful lot of news more or less inaccurate, and do themselves no harm through being so privileged. Fine, healthy sites have the stables on the hills between Lambourne, Wantage, and Newbury, with beautiful country in the Lambourne Valley - the Lambourne had retired for a while, after you are a little further up the omnibus line than Shefford, and was dry as a mouldy bone. I wouldn't care much to be there long in the winter 
months, let the bourne be bank-full in flood or dry as the turnpike road. But in summer what a range for a lucky holiday-maker to strike, ten thousand miles it might be from busy town life! As everyone knows, you have a chain of pretty villages all along the valley. Away on the high lands is some of the most lovely down I have come across so far, with fine scope for training, but a desert in the matter of population, and mighty convenient for losing yourself. Lambourne and Wantage have their colonies of trainers, so has Foxhill and Lyddington in a way; Kingclere's stables are within the village's bounds, but some of the quarters I visited last week near the line of the Lambourne are detached, outlying, adapted, solitary farm buildings, where, save for touting purposes, never a soul might casually come from one year's end to another.

One thing visitors to Newbury for the racing can do if they please, and that is, after liking the sporting pickles, try the local sauce--that is to say, sample the environs. A rare old-world district this is, with its water meadows and remnants of what must have been fens; a wellto-do corner, where everyone went in slow time about business, and I guess took long over meals and plenty of sleep. Artistic authority rules that any landscape is better for water in the foreground. Dr Johnson, who declared on his word as lexicographer that he never recognised a likeness in painting, or drawing, held, as we know, more material views, and went for a fullylicensed house, or words to that effect, in place of the water. I should be sorry to run counter to the art interest, but the Doctor is in the instance quoted very sound, and if I had my choice I 
would, I think, go with the Bishop of Bath and Wells, and take both. Anyway, to me water has a very powerful charm, running water especially, and the Newbury and Lambourne rivers are just the sort I do like. Give me something to lean against-the coping of a bridge for choice-and I have amusement for hours indefinite, especially if said bridge is high enough for the swallows and house-martins and sand-martins to sail under, and if there is a lusty trout about, here and there a grayling, and may be a shoal of sizable roach, with perhaps a warlike-looking old warrior of a perch investigating where a bit of woodwork occurs. I recommend all and sundry to do their Newbury properly, and if possible take Lambourne's light railway, for that quaint little settlement on the edge of the great spread of downs; or working towards Didcot on another line, where are Compton, and Chilton, and Ilsley (if you haven't seen Ilsley, a collection of sheeppens and public-houses, about one of the latter to every inhabitant and a half, pray do so). 


\section{CHAPTER XXIII}

IN WILTSHIRE

I OwE a lot to the Great Western Railway, for it is perhaps the one by which I travel the least frequently on what I may call hard, pressing business, but ever since I can recollect went holiday-making by. I wonder whether others have noticed what so often strikes me, viz., the wonderful way in which, as you journey westward you seem to get a long way "out of" London and its belongings in short measure of time or mileage. Fifty miles away on the Great Western Railway is to me almost twice as far as on most other systems. The point forced itself on me particularly one week when I had experiences available for comparison. On one and the same day I made three journeys on radii from the Metropolis, all of them jolly good, too. First from the Polegate district up to Victoria. The South Coast Railway did us well. Polegate is sixty miles away, and, I need not explain, in Sussex, on the plain between the South Downs and the next high lands up Mayfield and Crowborough way, where, if ventilation has anything to do with health, one ought to be very healthy indeed, for the winds hold it for a playground, and, my word! 
they do play sometimes. Polegate, you know, is Sussexy, but I suppose, too near to Eastbourne to show much marked provincialism. You don't feel there-at least, I do not--very far away from the Great Wen. My next route was from Paddington to Swindon, to call on Robinson at Foxhill. I could not make time to pay a visit to Eugene Leigh, who rents the stables the late Mr Bruce Seton had on part of Robinson's land. No one ever accused Leigh of being a lazy man. If he did happen to be so traduced, and wanted a character for industry, I can find him one. Said a rustic to me, when I inquired for purposes of drawing the countryman, not because I didn't know, "what trainer had the stud farm?" " $\mathrm{Mr}$ Leigh, and you may well call him a trainer, for he's training horses all day long, and, for what we know, all night."

Swindon market was on, and it was quite cheering to note the poor, long-suffering agricultural gentlemen who had so long been losing so much money in farming all so jolly well-to-doand doing themselves well, too. Now, to illustrate what I say about distance, take Swindon on a market day. The town itself is not so very old-fashioned-the old part, I mean-in fact, is rather up-to-date than otherwise; but, with its people, is as far from London as Dublin from Birmingham, in distinctions. After sampling so much Wiltshire, I had to make for Leicester, and again was happy in the journey per Midland. But for a little bit of a local accent Leicester might be part of London itself. It is twenty miles farther off than Swindon, yet while Swindon is remote in its ways, the flourishing Midland town seems not more out than a suburb. That 
was a pretty good day's work to thank modern facilities in travel for, was it not? On paper it is, but the excellent going made it quite easy. It shows what you can do. From East Sussex to London, from London to Swindon, drive fifteen miles out and back, rail to town, then to Leicester, which is just on a hundred miles-all in sixteen hours, with breaks of one hour, two hours, and four hours.

Given a good day for an outing in the country, I know not many tramps where I can do myself better than getting from Swindon over to the old inn where four roads meet at Beckhampton-the coaching-house, long turned into a residence, where Sam Darling now lives, successor of a line of trainers established there. A curious thing for me is, in this connection, that at various times I have approached Beckhampton five different ways - viz., from Devizes, from Calne, from Swindon, from Ogbourne, across the Manton House and Fyfield gallops through Avebury the ancient, and from Marlborough, on the 'ard 'igh road-and every time had a jolly good drenching, either on the out or return journey. On one occasion I beat record, for, after having about two hours of it on the outward journey, and then a spell of remarkably fine weather, I was treated for the third instalment to a dose which reminded me of the Scriptural threat of whipping with scorpions instead of whips. Such a turn of lashing with hail as fell to my lot climbing the crest of the long hill on the Marlborough-WoottonBasset road which comes out on the Devizesto-Swindon highway about seven miles from the last-named town I never had before, and do not want again. I could not hear the thunder- 
storm for the noise, which is a new parallel to not seeing the trees for the wood. The gale howled and the hail hissed to such a degree that a trifle like a peal of thunder could easily be mislaid.

Under the circumstances I must be excused for missing objects of interest I hoped to collect. Singularly "collect" is one I did bag from a very meagre rustic of whom I inquired my way when half over to Beckhampton, not because I should follow his directions, but for the sake of an excuse to foregather with the old party. On his employer's books he was laid up with the "neuralia," suffering also from strange pains inwardly, which he thought might be due to taking six nerve pills instead of two. In the flesh, and very little of it, he would not take much starving to make a skeleton. He was seeking change of scene and variety out on the lonely road under one of those heavy umbrellas only a rustic would ever try to wrestle with, as relief from lonesomeness at home, where he did for himself, and had not even a cat to talk to. Poor old man, he dared not go into the public-house, because some of his fellow-labourers, jealous of his life of ease and luxury while invalided, might report him, and the master put him to work, neuralgia in the head or no neuralgia. A willing-hearted sort of chap he was, but I should think longing for a little society, accounted for his offering to accompany me to the next finger-post, and, here comes the word, "correct" me on my way. Fortunately, being able to read, I knew as much as he did when we got to the "resurrections" set forth on the fingers, which, needless to add, he interpreted quite wrong. However, I believe 
I did him good by listening to his tale of troubles : moreover, I put him in position to start fresh with his stock of "neuraly" pills, or, at any rate, "take something for it" of another nature.

Do those who "use" the Crook and Shears at Clatford-between Andover and Stockbridge, somewhere about half-way, too--still bump their heads, I wonder, against its low ceilings? My word, what a bash I gave my poor head the first time I ventured into the Wagon and Horses at Beckhampton, where the roads from Calne and Marlborough and Devizes meet! The one I mean is the little ale-house a stone's-throw from Sam Darling's residence, which used to be a coaching inn before the rail ran away with the road's fast-carrying trade. Beckhampton is not Stockbridge, do you say? Certainly not, but the low door is at the Wagon and Horses in the former village to this day, and so is the bump on my head to prove me right - at least, I sometimes feel where I "raised a dent" on my skull. Besides, if it comes to being so critical, the Crook and Shears isn't at Stockbridge either, but at Clatford, the one right away off the road from Andover towards Red Rice, and not the other where the foundry is or was. My hotel, hard by that foundry, where I put up in years gone by, would have served at last as an illustration of Alice's residence-I allude to the timorous maid who was to have been Mrs Ben Bolt. As I saw it last, the little cottage was being dismantled, a strange thing to do with a licence obtainable. But then a good many strange things of the sort happened down in that part of the country, more particularly "stopping" Tom Cannon's meetings. I do hope that nobody has been led to disestablish 
another of my half-way houses of call, the Rack and Manger, on the road to Winchester, or the excellent shoemaker-sportsman-naturalist, whose tent was pitched in a hamlet hard by the footway up to Farley mount, or mound, burial-place of the celebrated land high-diver, the noble steed Chalkpit, whose godfathers and godmothers gave him that name on account of his carrying his rider over the edge of a chalkpit. A landmark monument, familiar, I believe, to Winchester boys, marks his tomb, and records also the horse's having survived the adventure and won a race or races on, I believe, Worthy Down. Some day I may, perhaps, go to pick up my marks again, and see how the beautiful spruce hedges down by Houghton are doing. Indeed, some day I shall land down Wessex way and not come back any more, but settle with a nice holding of my own, mostly upland downs, with a coppice here and there, and big trees round the homestead, and at the low side of it water meadows, with swift little brooks, and one big one that you may call a river running through the valley to make rich grass and harbour fat fish. That is the country for the poor man to enjoy himself in cheap.

Such is the county I came to while breaking, to me, fresh ground, working within a close radius of Salisbury while down for the Bibury meeting one hot September. Grand it was to see the crops. I should have liked to have had with me someone used to Leicestershire, in my opinion the poorest apology for country-all right for its particular sort of farming, but in my eyes the least picturesque and the poorest after the market-garden agricultural tract in the so- 
called Thames Valley down at the back of Kempton Park, and pretty nearly on to Staines. It would have seemed as strange to him, accustomed to small enclosures with plenty of hedge to them, to come on widely spreading, rolling prairie laid out in parcels (but not divided by boundaries) I am afraid to say how largevery nearly a square mile sometimes. There is an expression which fits for describing the feelings of one taken from wide open plains or downs to land cut up into small holdings, and I recollect its being used by a traveller on the Midland Railway route from Liverpool to London. He had just come across the American Continent, and you couldn't wonder at his calling ours "a pocket-handkerchief country."

Of course it was hot getting about even early a-mornings; but then I have a theory that if only you are hot enough no amount of sun will hurt you. That may be wrong or right, as may another of mine, acting up to which I drink just as much as ever I feel inclined to while in a profuse perspiration. As soon as you are old enough to be told anything, you are instructed that you must on no account drink when you are hot. So do they warn you not to go into cold water while you are perspiring. I don't say that you are to get red-hot, then drink what you will and stand about to grow cool, and maybe take a chill. But I do say that if you want to do yourself real good by sweating through physical exercise, a nice pull at something wet is calculated to forward your purpose all round. Being of that way of thinking, and, I may add, modelled by Nature from a sort of clay which readily absorbs moisture, I do find the Wiltshire downs somewhat 
trying for want of what Dr Johnson declared to be one of the most charming features in any landscape. It is a precious long way between the chances for a drink, even if you count water in that category.

But plenty of refreshment of another sort is on hand. Refreshing it is to get on the ridges under the woodside, or on a drive, such as one that runs for seven or eight miles straightway from Wilton, as wide as a cricket pitch, mostly turf, and edged with graceful birches, stout oaks, and freely-grown spruces. You don't want a boundless contiguity of shade if you may find a way like this, with one bosky side always so far as my rambles went. Besides, with the aforesaid contiguity you won't see much. Wild flowers are not likely to flourish unless the sun can get at them, nor is there much animated nature in work under such circumstances. Very little of that sort of animation do you find on these ranges, unless it is among the inferior animals. For that reason it is advisable first of all to learn how the points of the compass lie before you set out, and at that not to lose your way. You may go a tedious while and not see a soul. Much labour must be employed, as the fine crops of wheat, oats, and barley testified. I never saw such good ones on hill land like this before, but all the same you may go for miles without coming across a soul to speak to. That I don't mind, and never did, though it is quite as well to know that if you did happen to sprain your ankle you would probably be found in a day or two. The desolation of a very great part of England preaches a strong sermon on centralisation, does it not? Some of the sermon preached itself to 
me the other day in what may reasonably be called a lonely part near Salisbury Plain; but the same story tells itself also within a dozen miles of London as the crow flies, where the population outside the villages themselves is as thin almost as in a newly settled country.

A good deal might be written about the Salisbury downs and valleys such as Wylie, or rather Fisherton De La Mere, Mr F. R. Hunt's fine fishing in the stream, which always makes me want to get in and have a swim, and the beautiful gallops that insist on my walking to look at them; of the charm of the little villages up the valley to Wylye (the name is spelt all manner of ways, and the milestones and Her Majesty's Post Office department do not agree on the subject), and of one hamlet in particular where, barring that the mise-en-scène was peculiarly English, as English as Constable's "Nearest way in Summer Time," I might fancy myself among our soldier men fighting, say, in South Africa. Along came a puffing, quickmoving, road traction-engine, with a train of big wagons, dusty as they might be on the veldt, and their military occupants, powdered to match, looking hard and fit, not troubling too much about appearances, but ready for anything at any moment. Sun did not damage these hard-working warriors-a convoy who, curiously enough, called a halt exactly abreast of an inn where, also curiously, I happened to be at the time-but it made the inside more appreciable to the drouthy. I am running on, I find, but I must have just a word about this pub., or rather its users. A party, evidently "regulars"-i.e., stock customers-were partaking of their lunch 
beer, and discussing the affairs of the nation at large and in small. The church bell tolled. "Who's that for?" asked one of the little party. "Rasmus Wintle," said the landlady. The inquirer pulled out a book, referred to it, and then referred to the deceased in most kindly, sympathetic terms. "Dang his old eyes," says he, "he's the third on our club done it this month."

I have seen Weyhill, but too late to please me. The right time to gain acquaintance with the place was before I was born, when railways were not, neither auctions at every little town's market; and when live-stock exchanges such as Weyhill's and any number of others flourished exceedingly. Those were the days of smockfrocks and "statties," also pleasure fairs as the chief show diversions for a country-side, saving the club feasts; long ere excursion trains carried off dwellers in the wilds and their spending-money to the big towns. A celebrated ditty relating to Guy Fawkes, that Prince of Sinisters, does, as readers will recollect, account for a great many things not happening, as, for instance, Guy's inability to come that way-meaning over Vauxhall Bridge-because it wasn't built, sirs. On analogous reasoning I can account for Weyhill in its heyday and myself having been strangers. It was built far enough back. I was not, so I could not come that way in time for its glories. Now that I have gone over the fair ground with its very reminiscent, if dilapidated, fixings, I shall not be satisfied till I have done one of its fairs, the best of the period.

Newmarket, I believe, or feeders in that corner of the Eastern Counties, used to buy largely at 
Weyhill fairs from breeders of Hampshire Downs, also those crossed with the smaller Southdown. If only for that reason I, as a firm believer in Newmarket mutton, must hold kindly feeling for this centre of distribution. I went to it full of ideas, fancy pictures of what I should see; not one of them, except a biggish stretch of common or, at any rate, open land, was a little bit like the real thing. Why, I am unable to say; but somehow, though I am on visiting terms with many and various fair fields, I had chosen to construct this Hampshire one on the model of the not far distant neighbour in Berkshire, East Ilsley. There you find a small group of buildings, a little church, with a long-deceased Lord Mayor's (I mean Lord Mayor of London) tomb in it, two or three training stables, one "Somebody's" house, and a mixed medley of more or less fully licensed premises, with residential properties in proportion of about one and one- $a$ pub. for each establishment not in the licensed victualling interest. All the lot are huddled up together, with sheep-pens squeezed in among the bricks and mortar, and hedging in the whole hamlet. Not a bit, not a scrap, like Ilsley is Weyhill in this regard. There is a church, true; so far the two are on Monmouth and Macedon terms, with, I may add, churchyards to both; Weyhill, however, has also an annexe which makes you wonder where all the people come from to be buried, especially as the local air is so fine and strong. But, whereas dealers and pleasures at Ilsley find licensed-victualler traders to satisfy their wants in refreshment at permanent emporiums, Weyhill's connection bring their own caterers with them, so to speak; and for these are branch 
offices, shanties set up for fairing purposes and shut up on other dates. Remains they are, mostly, of former prosperity ; not exactly tumbledown, still, the sort of property you would want very well done up by a landlord before you took any on repairing lease. When you have got them you must take them in the rough, the very rough indeed.

Do I expect Carlton Hotels and Cafés Royal in the midst of wild Wessex, and are "à la" menus in my opinion appropriate for hungry bucolics requiring a very great deal for a very little money and going more for quantity than quality? Them are not my sentiments at all. Still, perhaps I am not wrong in saying that, all round, people want things a little more "classy" than they were in the Crimean war times. That being so, I may be excused for writing them off as not quite up to date, if they are now presented unrestored after standing the stress of half a century's wear and tear without suggestion of ever being closed for alteration and repair. A concern out by itself is the Weyhill fair ground, that has to be experienced to be appreciated, and must miss most of its significance to an observer who has not seen men and cities and chanced in his travels through bookland to tumble on the school whose speciality was the agriculturist of the bygone age and his aids. Having without the slightest justification looked for a little colony glued on to the side of a steep hill, after the fashion of the village in Robin Hood's Bay, up Whitby way, only on top instead of at the foot of the steep slope, I was at first vexed that all was different from my fancy sketches. What village, per se, exists is scattered-at least the 
inhabited part is, with some great men's places outlying. But a great settlement of mainly flint and slate with some thatch hutches and shanties, not forgetting the shebeens, runs in double file for-what shall I say?-half a mile, or getting on that way. Nearly all are constructed with the upper half of their low frontage to open on hinges, and so make a stall. There they are by the score and score, all the worse for wear, yet good enough temporary quarters for dealers in everything agricultural, from beer to breeches and from hops to sheep dip, not to mention the comestibles and indigestibles, the dinners and lunches and teas, and the fairings offering something like perceptible percentage of value for money, as, for instance, whelks and ginger beer, down to the innumerable collection of uselessnesses, to me symbols of teetotalism as she is spoke in the big gala-run on Newcastle's Town Moor in opposition to Gosforth Park Races.

Imagine three-quarters of a mile on end of shedding, originally insufficient for the requirements of the thousands of Jocks and Jennies who hied them to the fair for enjoyment after, or concurrently with, the enormous trade done, having live mutton for leading article. And imagine your humble servant all alone by himself gazing on these, which, if spick and span, instead of not showing a foot of paint to the lot of them, would be as cheerful as a bathing-machine in mid-winter. I had a long spell, peopling the place, dressing the scene with early nineteenth-century supers and accessories, while really I had for sole company only broken bottles, old oyster shells (blue pointers alleged), and notices two or three deep of somebody's dinners, luncheons, and teas. 
The twoness and the threeness deep comes from the practice of the last holder of a "restaurant" setting his name on top of his predecessors', without cleaning the old posters or other notice off. I looked about long for a comparison with the deserted encampment. The great unoccupied town of trumpery holdings with no sign of life nor care, where, ever and anon, the pulses of traffic and pleasure have beat fast, up North, gave me remembrances to go in double harness fairly well. 


\section{CHAPTER XXIV}

\section{WILTS AND HORSES}

I SUPPOSE, readers, that most of you would be only too pleased to own a Derby favourite and train that same yourself? You would? So would I; but I should want to hedge a bit by way of insurance against going off my head while the last turns in winding up were being twisted round. Such possession carries very big greatness, and from greatness I always pray to be delivered. No need to pray on those lines, say you, nor to petition for guid conceit o' mysel'! Say what you like; I write what I feel. The penalties of greatness make a heavy load, and I am with a very eminent trainer who has won a Derby. Said he, "I've been through it, and it's killing business thinking of the risks." I pity the nobbler who tried to get at Sceptre, for instance, while the beautiful mare was being prepared at Shrewton for Epsom. But putting myself in her owner-trainer's place-I did so literally in one way as a visitor-I felt that I should be heartily grateful when the Wednesday was over, win or lose. To anyone not armourplated in the matter of nerves the tension as the day draws near must be awful, and I can quite 
understand Lord St Vincent's feelings about Lord Cliefdon as he related them to me, and his shying at seeing the St Leger. Per favour of $\mathrm{Mr}$ Sievier I went over the gallops-beautiful going they are upon Salisbury Plain, where the War Department holds fifty square milesinspected the favourite's fine roomy box; saw her fed; made friend with the several dogs, who can be very unfriendly; noted the perfect arrangements for keeping watch and ward; and came away almost thankful that none of the great responsibility was my portion, for I was thinking all the time of how some of us have felt before a twopenny-halfpenny athletic race, and what we would have given to cut out a day or two prior to the event.

In my experience I never knew a less racy village than Shrewton as harbour for a big equine celebrity. You see none of the usual signs; the horsy, hanger-on class loitering about the public-houses (of which there are as many as usual in remote hamlets where much sheep- or cattle-fairing goes on), the stable-boy off duty, the general air of knowingness resident locals assume-an attribute which, if genuine, usually leads to their financial destruction, seeing that it is customary for such as really do hold knowledge to back all the stable's losers, and something else in the winning races - the unmistakable touts adorning the telegraph office, and the suspicious-looking strangers. Shrewton is an out-of-the-way hamlet ten miles from anywhere in civilisation, and eight from the nearest railway station. So far from looking like the home of a Derby favourite in whom all the racing world was interested, it might be 
not at all on the map. More, if you go a couple of miles away from it on the great Plain, you might almost fancy that you were not only off the map, but out of the live world-when, that is, the horses are not out, or the soldiery about. Save for marks of military occupation hardly a sign of life is there in the human way, and scarce a bird, only great overmastering silence, which would worry the life out of yours truly, because in any vast solitude with a boundless contiguity of still, inanimate scene, I invariably fall to "making up" the worst that can befall. Put me for a week before the Derby-which Heaven forbid- - at Shrewton, I would be doing the amiable philosopher all upside-down ways, finding books full of miasmic fogs in the running brook-which as a matter of fact was all dried up, and made you wonder how the big flood of I 849 could ever happen-sermons on accidents in all the stones on Sceptre's roads to her gallops, and no good in anything but possibility of upsetting the favourite. Give me my choice of vocationsowning Derby favourites, with vast winnings ahead, and making holiday notes on very humble scale of assured remuneration, I jolly well know which choice would be mine. Go for the favourites? you say. Why, yes; most certainly I would, and as soon as I was granted my wish, pay to get out and be my readers' free and unfettered servant. Uneasy lies the head that wears a crown. I would sleep easier on a plank and in a nasty spiky crown-all points and knob-than furnished with the cosiest bed in the world, and a big race favourite next door and on my mind. I might, too, happen to shoot the head lad by mistake, and possibly disturb Sceptre 
every ten minutes to see how she got on, like a youngster pulling up a plant by the roots to find out whether it was sprouting or not.

Some of our outlying trainers must at times get to feel very much like the men in charge of lightships. There they are, approachable through a long, eye-tiring avenue of dust in the summer. Little settlements clinging for dear life to an almost perpetually wind-vexed anchorage in winter, and, but for association of the establishment's hands about the camp, solitary as shepherds out on the downs. But don't think that if the master and staff are detached from the world in voluntary exile they are lonely as the word is frequently understood, because they are not. For no one who has not tried the life a little could realise what a precious lot there is to do in never-ending work. By the time you have left off at night the next day's work is almost due to begin, and, as for accounts and correspondence, I think the noble animal is more provocative of these industries than any article of his weight. His requirements, too, are various, and you have never quite done with him to the extent of being able to close the letter-book or block of telegraph forms and saying, "Thank goodness, that is done with now." Somehow or other, occasion will be made for posting a boy off on a bicycle to cover an item forgotten. Just sit down and make out a map of the bother and fuss incidental to getting a selling-plater off from one of these hill stations to a racing place-say, Yarmouth -the inquiries and answers, arrangements and informations. No; a trainer in charge of a moderate string has his work cut out. 
As for fame-fame! Well, look here and listen to me if you want to know about fame. Attracted by the large and varied assortment of wide, tall, feathery, dense, spindly, bushy gin or juniper trees-called, I believe, "The Junipers" -I wandered away from Mr Frank Hartigan's pinkwashed house, with its most picturesque and very excellent stabling, and must have got threequarters of a mile off. At that remote range no soul I met had ever heard of Captain Saunders Davies, $\mathrm{Mr}$ W. H. Moore, nor the present occupant of the stables, some of which were built by a great horse-dealer, Mr Barnes. Wagoners I met, hinds doing something to the land I came upon earning their wage, gamekeepers' good ladies and woodcutters' families I called up, seeking knowledge for myself and finding none. Could they tell me where $\mathrm{Mr}$ Hartigan's horses did their work? They could not, because they had never heard of $\mathrm{Mr}$ Hartigan, nor his occupation, nor his horses either. Citing Why Not, The Soarer, and Manifesto, all Grand National horses, trained almost on the edge of the fair ground-and what a champion, Manifesto!-not to mention the then favourite for the National, could not touch any spot within their memory's armour. They knew and cared for none of these things. All that mentioning the creatures effected was to render the peasantry somewhat suspicious of your working up to a sell. They are worse even than the district's finger-posts; you can get some information out of the latter; the trouble is to know what to do with it. Whatever artist set these up was not too eager to put you in the way you should go. He left you so that you 
might take your route and your chance. Apparently, in their calculations, you can reach anywhere if you only keep on long enough. A flat bit of board with "To Something or Somewhere" is nailed on a post, but whether you are to go on or back is left unstated. The shortest plan is to start off and peg away till you get somewhere to make inquiries.

We have classical authority for the efficacy of making believe a good deal, as witness the Marchioness, afterwards Mrs Richard Swiveller, and the manufacture of negus out of orange peel and cold water-a concoction grateful, warming, and comforting provided you persuade yourself that the base imitation is the real genuine article. I tried very hard one day on Salisbury Plain in mid-March making believe that I was taking in all the joys of open downland. When the sun is on your back and, metaphorically speaking, patting all animal, insect, and vegetable life on their backs, setting them going, so to speak, keeping them at it, and presenting everything in a kindly light and doing its best to be all alive and interesting, the open uplands are hard to beat. Up on the great downland where I happened to be, a little bit of sun makes a world of difference. I never can quite make out where Salisbury Plain begins and ends. I do know that it does not go farther one way than the break before you get to Marlborough. Getting down on the Dorsetshire side it seems to me that, though you may call the territory by any other name, it is the same old plain; and if there is one particular tract in England where a touch of sun makes a strong difference, you can find it up in that direction. I had heard so much about Sir Charles Nugent's 
schooling fences at Cranborne, which is a village some distance from his stables--these last being a goodish step from the gallops-that I, following, as I always do, the Inimitable's philosophy, went to see the Medway, as Mrs Micawber did when her family perceived in the coal trade on that river an opening for Mr Micawber's talents to be turned to account. The first thing, said I, is to see my Medway, the fences, and, as I have indicated, these do take a lot of getting at if you start from London. The South-Western's fast service gets you down to Salisbury in fine style; there you switch yourself on to another line, the one that follows the Avon's course more or less to Bournemouth, or, I should say Christchurch, which is next door like, and, as I have sampled it, gives one leisure to view the land at ease. If I had to go any distance there is one means of progression I could not profitably adopt, and that is walking, for every time I could get near that beautiful hurrying, clear river I should be loitering and hanging about. I can waste my time for hours at a stretch looking at a bit of a brook, so you can by the aid of a very simple sum in proportion arrive at the idling to be got out of a fast-flowing, fishy stream like the Hampshire Avon, which adorns other counties, and was for the most part of the run observable from the railroad in Wiltshire, and when I left it not so far from the Dorsetshire borders.

To return to our muttons, in which flock is the sun, a bit of a black sheep this time because he would not do what was wanted, and that was just to turn the light on. Instead of which, we had one of the coldest southerly winds I ever experienced. Throughout the low land, full of 
lovely streamlets, not forgetting the river, you got the wrong impression altogether, made to see it at its worst, all bleak, cold, and miserable, with never a touch of comfort in it when you sorely wanted that same. Cold and cheerless in the extreme it was down that way, and hardly any better in sheltered parts of the journey to Cranborne village. About Cranborne, on the climb towards the unbroken turf downs, one felt quite a grievance against the sun for striking work. Why the deuce wouldn't he put a smart face on things and, at any rate, have a round or two with the chilly winds? Apparently, though in the hollows the primroses were just lovely, hedgerow vegetation was very, very backward, and very wisely so, too, you might think, considering what it would have to put up with in its tender youth from weather like I was experiencing.

A month later, I should say, than their fellows at, we will take Plumpton, were the bushes and so-called weeds that might have been green if they were not so backward. If it had not been for the lambs and just a bit of show of bloom on the forest trees, you would not have known that spring was on the road at all. You could not make a mistake in another direction-viz., the splendidly strong air, which might be more palatable, perhaps, if it had been put down in front of the fire or in hot water for a few minutes before the contents of its vials were poured forth. There was sufficient wind there to the square foot of most bracing air to keep a sanatorium for the weak-chested going, and, for the other sort of strength, to turn enough mills to generate all the electric supply of the country. If anyone cannot be healthy where Sir Charles Nugent's 
house is placed, the subject must have a very weak place somewhere. There was wind there to blow daffydowndillies out of the ground; but, then, I would a lot rather have the benefit of such tonic breezes than be able to grow any quantity of bulbs, from the most expensive and ornate down to the very estimable savouries of the onion family. The stables lie a goodish way off in a sheltered corner, and are made, in part, by reforming old farmery premises. Over the way is a high ridge, beautifully wooded, and in its shelter Boveridge, where is Mr Thursby's house and also the stables whence so many winners were sent out. I had hoped to call and see Mr Thursby, but heard of him being out wasting on the road to Salisbury. Mighty convenient for that purpose his place lies, because you can have an eight or nine mile or a bigger walk, right away to the city, and make the half-way house, or, for the purposes of exercise, your terminus, at the funny little Turkish Bath, which has more than once done me good service.

Curiously enough, I have on several occasions chosen Salisbury and its meeting in May to have lumbago, have gone to these baths, and have come away cured. Of this relief I was pointedly reminded as I toddled along from close to Woodyates, for ever to be associated with the name of William Day, writer of the most informing racing and racehorse books ever published. But of the symptoms more presently, as we have a word on the return journey. Let me, if possible, cut the cackle and do the other thing. As in duty bound when the master of the stables invites you, I paid respect to the stud. With most of its members I was on speaking acquaintance, and 
was glad to extend my knowledge of the company by being introduced to some splendid Irish-bred two-year-olds. Drumcree was hospitably at home, staid and friendly. If anyone takes on the job of doing horses-I do not mean strapping them, but the Special Commissioner businessat so much per head, he ought to get extra pay for John M.P. Every time I see John M.P. he appears to have added a cubit to his length. A more tractable, docile, pleasant old party, intelligent withal, you will not meet, nor follow, in a day's march, no matter how far you go. John gives the impression of knowing it all the time and being quite satisfied with things as they are. John M.P. is a national favourite-I am not writing now of the great steeplechase, with a capital N. My reference is to his being held in estimation by the English racing world, as are and have been few horses whose catching on to people's affections is frequently in the first place accidental. Bendigo's sensational Cambridgeshire put him where he was for ever afterwards. Mr Tom Worton's Victor Wild somehow attracted kind regard, and held it throughout. I swear that Victor bowed to the house when given a hand as he went to the post. Sceptre-why, those who won when she got beaten were sorry for Sceptre ; and as to Pretty Polly, if a general subscription would save her from bad luck the money would be there. Then look at Manifesto. Every man and woman at Aintree on a National day wanted to pet the Grand Old Man of 'chasing. Other horses might be all very well in their way, but Short-meaning Long, for he was wonderfully lengthy-Manifesto was the friend. As for the Silent Member who made so much noise- 
not as a roarer, please understand-I think it was his carrying off that little hurdle race at Windsor with a hundred to one laid against him that first put him in the list of the specially considered. Anyway, there was, standing quiet as the proverbial sheep, at one end (the head one nuzzling up to his trainer-part-owner, while at the other, some yards away, his attendant was vigorously massaging the leverage section.

Over at Woodyates are another lot of horses trained by Sir Charles Nugent. I did not see them, but I went to see the downs, and, even under the influence of a south-wesser stuffed full of north-easterly bitterness sprinkled with flecks of ice-cold rain, fell in love with them. I do not know how long it is since I came that way, and then did not do them properly. Here is fine old turf, close cropped, so with plenty of roots-it is the roots you want-bother the "herbage"-elastic and making true going. All sorts, lengths, shapes, flats, descents, ascents, every kind of gradient and plan is available for preparing horses. I had got into my head that as Sir Charles Nugent went in almost exclusively for jumpers there might not be the right sort of galloping for flat racers. Instead of which I should not like to have to name one to beat his grounds. When William Day was at the neighbouring Woodyates, and hiring gallops was not such dear work, he must have had facilities for training pretty nearly all the horses in England if he could have found stabling for them. I was reminded of another prominent figure in that connection as I passed the little pub. on the Blandford-Salisbury road. There Sam Adams, who rode Catch 'em Alive, once lived, and I believe, for a period was landlord. What a 
change from a petted jockey's life to bossing a roadside shanty, nine miles from a town and four from a village no bigger than a hamlet!

I suggested to my host, who took a lot of trouble to shepherd me over the district-where, barring the early wheatears, the grey plovers, Hocks of larks and shoals of rabbits, and a fine foss and vallum, there was not another Christian soul to speak to-that I knew how it was he pulled John M.P.'s spine out to be its proper length and a half. "That," says I, "is the dolls' secret, the secret of the movable barrier. It is like the milkmaid's beginning with lifting the newly born calf, and by virtue of doing the same every morning, not noticing its increase even when it is a great big fat bullock-you keep at it, you see; that is where it is. Now, with John M.P. and these dolls," I says to his master, says I, "you have been putting the shifting-guard rails out and out, an inch at a time, after the fashion of boys playing footit-that interesting game which costs parents so much in caps. The inches have accumulated till the poor deluded animal has been taking off in the next field or the next parish, and the while not knowing he was doing anything extraordinary. Of course nature always adapts herself to circumstances and her children's requirements; so in these extending exercises John has telescoped-or, rather, untelescoped-himself to the length of a street.

Now behold the irony of fate! At the end of my visit I was kindly driven round on the downs between Cranborne and Woodyates, and landed finally some half-mile below the latter isolated outpost, with a clear run of nine miles or so into Salisbury. I had heard that Mr Thursby was 
out at work, and as I wanted to see that gentleman, this promised to be a very convenient arrangement, for $\mathrm{Mr}$ Thursby does an enormous amount of walking, and does it mostly on the Blandford Road. And that was where I sought him. Without calling myself a rogue, I do not care for these straight Roman roads. You see such an awful lot in front of you, and if you look back are impressed with the amount of labour you have already had to go through. Once in a way these straight-ruled ancient tracks are all very well. They were this time as I padded along, passing many a lambing-fold with attentive shepherds and watchful dogs, meeting carrier's van after van bringing folk on long journeys from Salisbury market, loaded with goods at the back, and men, women, and children huddled up forward under the tilt or latter-day equivalent. Young men were trudging alongside for company, and tikes, mostly wall-eyed, personally conducting the whole expedition. I liked the outing much. Besides, being able to see the tip of Salisbury spire helped me to forget the road's directness while it lasted, and I was getting plenty of satisfaction till I came upon evidences of disaster and trouble for myself, of which last I was given long enough warning. In the middle of the road was grief-a little nag lay with the shafts of a cosy gig under him, and the harness twisted so that you could not unbuckle it. By his side knelt the good mistress holding his head, while the master vainly tried to ease the poor creature, who was pretty bad. The nearest village was a mile off, and naturally, when help might come through them, the procession of caravans from Salisbury. had ceased. Night was falling, and, 
as the owners said, What were they to do with the poor little horse? Of course I must forget all sage advice, pull up, and lend a hand. I found that our united strength availed nothing to clear the trap, and the cold wind did not fit the extra warmth induced by exercise. In fact, the mischief was done. I was reluctantly obliged to consider myself and travel on. But at the pretty little village, Coombe, I interviewed two fine lads at the smithy, who left a half-finished horse-shoe to cool, whipped off their leather aprons, and were on the road at a double to the rescue before you could say Jack Robinson or I could stand them a drink for being jolly good fellows.

So as to have a proper understanding of myself, I soliloquised. Says I to myself, you understand what you have been doing and what you are to do. By force of circumstances you have been driving about on the Downs in an open trap and a not heavy ordinary walking suit, thin socks, low shoes, giving chances for a bad cold to come to you. Get away brisk now, stir your stumps, don't slacken for anybody or anything until, having got thoroughly warm, you have sweated out the cold that may be coming. Then you will have enjoyed yourself, and have had a power of good done to you. Go at the job half-heartedly, and, if harm does not come of the slackness, count yourself better off than you deserve, because you are flying in the face of Providence. The matter is very simple: you cannot afford to be any colder, and you must get warmer. Anything like simmering down on the way means bad trouble. This was Tuesday night. On Wednesday I got to Newmarket, where next morning, deluded by a patch of 
blazing hot spring sunshine, I plunged into a bath of freezing atmosphere carried on a gale that sent the chilliness searching into me in the way that up-to-date salt beef is made, with tremendous hydraulic pressure. This latter so impregnates the meat's tissues and fibres with saline decoction that at the finish there is a sight more decoction than beef-as you find when you come to cook it.

The next thing worth noting was my good doctor's speaking and giving forth his opinion like one who knows what he is talking about. "If you cannot understand that a man with a temperature of a hundred and three, and no legs to carry him, is unfit to go out in a bitter wind, you must be___ I was so afraid he was going to say "A bigger fool than I took you for," that, for fear he might offend me, I interposed as some sort of defence, that I was sure he could patch me up for Lincoln on Monday. Now, it is curious, is it not? what a lot these medical men get to know somehow about racing. This one must actually have had the fixtures pat, for he went through the whole week, playing a full hand on me. "I shall not patch you up for Monday at Lincoln," says he, "nor for Tuesday, nor for Wednesday; nor for Thursday at Liverpool, nor for the Grand National Day, nor Saturday either." $\mathrm{He}$ had got the lot letter-perfect ; "and," he added, " if you start unpatched, I will come with another doctor who will do anything I tell him, and two ready-filled-up certificates, and have you locked up as a lunatic." So as not to seem at all domineering in the business, he wound up with a bland assurance that I was altogether my own master; and left me in the flattest part of Bedfordshire, old 
Bill Barley the Second. And it isn't, after all, half a bad rôle to play if you got plenty of people who don't mind being blown up for anything or nothing, to wait on you, and are absolutely indifferent yourself about the whole blessed country's going to pot-not to mention your own business and all.

[NoтE.-The chill taken by my father in halting to try to help with the "poor little horse," as told above, was the immediate cause of his death. His self-forgetfulness and sympathy came out unvaryingly all his life through.-ED.] 
P R I T E D B Y

OLIVER AND BOYD FDI YBURG A 


\section{The Cheapest Books in the World}

Price 2s. 6d. each

The Life and Adventures of Robinson Crusoe. A verbatim reprint of Stothard's edition of 1820 , with reproduction of the 20 engravings. 384 pages. Demy 8 vo.

The Arabian Nights Entertainments. A reprint of the first edition of Lane's translation from the Arabic, with the addition of "Aladdin" and "Ali Baba," taken from another source. 512 pages.

Uncle Tom's Cabin. By Harriet Beecher Stowe. With a frontispiece by GEORGE CRUICKSHANK. A verbatim reprint of the first English Edition. 320 pages.

The Swiss Family Robinson. By Johann David Wyss. With 8 full-page illustrations by RICHARD MATHER. 320 pages.

The Count of Monte Cristo. By Alexandre Dumas. The entire text. 576 pages.

The History of Tom Jones: A Foundling. By HENRY FIELDING. A verbatim and unbowdlerised reprint of the first edition (I749). 5 I 2 pages. With a frontispiece portrait of the Author.

The Romance of War. By James GRant. 5 I 2 pages.

Don Quixote. JARVIS's translation from the original Spanish of Cervantes. With the life of the Author, and with I 6 new full-page illustrations by W. H. RoBinson. $64^{\circ}$ pages.

The Pilgrim's Progress. By John Bunyan. With a short biographical notice of the Author, and bibliographical appendices. With a frontispiece portrait of the Author, and 24 new full-page illustrations by W. H. RoBinson. 320 pages.

The Poetical Works of Sir Walter Scott. Edited by G. S. With a frontispiece portrait of the Author.

** The above works are printed on choice antique laid paper, and bound in cloth extra. Gold back and gold lettering on side. Gilt tops. Demy 8vo. 


\section{The Prize Series}

\section{Price 2s. 6d. each}

For size, and for combined excellence of type, printing, paper, and binding, and-not least-for lowness of price, the undermentioned works will be found to stand out prominently among the mass of cheaply bound and worse printed apologies for books that are too often nowadays offered as suitable for children's prizes.

Andersen's Fairy Tales. Complete. A verbatim reprint from the first and second editions. With I 6 new full-page illustrations by W. H. RoBinson, separately printed on plate paper and inserted in the volume.

Assop's Fables. A new edition, with Proverbs and Applications. With over 100 illustrations. Printed on surfaced paper.

The Wide Wide World. By E. Wetherell. With new frontispiece by W.T. Smith. Printed on antique laid paper.

Little Women and Good Wives. By L. M. Alcotr. With a new frontispiece by W. T. Smirh. Printed on antique laid paper.

The Pilgrim's Progress. By John Bunyan. With frontispiece portrait of the Author, and 24 illustrations by W. H. RoBinson. 320 pages.

The Swiss Family Robinson. By Johann David Wyss. With 8 illustrations by Richard MATHER. 320 pages.

Uncle Tom's Cabin. By Harriet BeEcher Stowe. With a frontispiece by GEORGE CRUICKSHANK, and 8 illustrations by LouIs EDWARDS. 320 pages.

The Life and Adventures of Robinson Crusoe. By Daniel Defoe. With 20 illustrations. 384 pages.

Cranford. By Mrs Gaskeli.. With I6 full-page illustrations by T. H. Robinson.

The Vicar of Wakefield. By Oliver Goldsmith. Illustrated.

Lamb's Tales from Shakespeare. With I6 new full-page illustrations by W. H. ROBINSON.

Grimm's Fairy Tales. With I 2 new full-page illustrations by John Hassall.

* * All the above works are square demy 8 vo, are re-set from new type of large size. Each volume is carefully printed on fine paper, luxuriously bound in the best cloth, and lavishly decorated with gold. Gilt tops. Price 2s. 6d. each. 
Via Dolorosa. By "A North Country Curate." Price $6 \mathbf{s .}$

Bog Myrtle and Peat. By S. R. Crocketr. Price 6s.

Racing Life and Racing Characters. By Martin CobBetT. With many Illustrations. Price 6s.

The Tragedy of Chris. By Rosa Mulholland. Price 6s.

Valiant and True. By Joseph Spillman. Translated from the German by A. C. Clarke. Illustrated. Price $6 \mathbf{s .}$

Lucius Flavus. A Tale of the Siege of Jerusalem. By Joseph Spillman. Crown 8 vo. Price 6s.

The West Find. By Percy White. Price 6s.

Alsatian Tales. By Jean Delaire. Illustrated. Price 5s.

A Branch of Laurel. By A. B. Louis. Price 3s. 6d.

The Devil's Kitchen. By A. B. Louis. Price 3s. $6 \mathrm{~d}$.

Pearl. By Olive PARR, Author of "The Children's Cardinal," \&c. Crown 8 vo. Price 3s. 6d. net.

The Knights of the Cross. By Henryk Scienkiewicz. Price 3s. 6d.

The Bank Edition of Popular Poets :-

The Poetical Works of Robert Burns. $55^{6} \mathrm{pp}$.

The Poetical Works of Sir Walter Scott. $753 \mathrm{pp}$.

The Poetical Works of Milton. $423 \mathrm{pp}$.

The Poetical Works of Thomas Moore. 5II pp.

The Poetical Works of Henry Wadsworth Longfellow. $380 \mathrm{pp}$.

The Poetical Works of Lord Byron. $727 \mathrm{pp}$.

Each volume is re-set from new type, and contains a Photogravure Portrait and a Short Biography. Bound in blue cloth, with gilt lettering, wrappered. Price 1s. 6d. net.

The National Sporting Club: Past and Present. By A. F. Bettinson and W. Outram Tristram. With numerous Illustrations. Crown 8vo. Price 6s.

Billiards for Beginners. By John Roberts. Crown 8vo. Price 1s.

The Whole Art of Billiards. By F. Hotine. Containing diagrams of actual play by the most famous professionals, including a match between Roberts and Stevenson, a professional 300 up, a 267 break by Diggle, hints on the up-keep of a billiard table, \&c., \&c. Price 2s. 6d. net.

My Man Sandy. By J. B. Salmond. With cover design by J. HASSALL, R.I. 


\section{THE FALSTAFF SHAKESPEARE}

The Tempest.

The Two Gentlemen of Verona.

The Merry Wives of Wind. sor.

Measure for Measure.

The Comedy of Errors.

Much Ado about Nothing.

Love's Labour's Lost.

A Midsummer Night's Dream.

The Merchant of Venice.

As You Like it.

The Taming of the Shrew.

All's Well that Ends Well.

Twelfth Night; or What You Will.

The Winter's Tale.

The Life and Death of King John.

In this, the "Falstaff" Edition of Shakespeare's works, the order in which the plays are presented is that of the first folio edition of 1623 " "Pericles," which was not included in that edition, and the Poems being added at the end of the volume. No new reading of the text is attempted; and only those variations from the text of the learly editions are included which have been accepted by the best Shakespearean critics. The task of the present Editor has consisted solely in the choice between the readings of these critics, where they disagree. For the most part the text of Delius has been followed.

In one large, handsome, and well-designed volume.

Size-Large super royal $8 \mathrm{vo}, 10 \frac{1}{4}$ by $7 \frac{1}{4}$ inches.

Type-Re-set from New Bourgeois Type, and printed with large margins.

Paper-Choice Antique laid.

Title-page printed in red and black.

Uniform in size with the "Falstaff Shakespeare."

\section{THE LIFE OF SAMUEL JOHNSON, LL.D.,} and the Journal of a Tour to the Hebrides. By JAMES BosweLL, Esq. Edited with Notes, and a Biographical Dictionary of the Persons named in the work, by PERCY FiTzGERALD, M.A., F.S.A., Author of "The Life of James Boswell," "Boswell and Crocker's Boswell," \& c.

This Edition is a reprint of the Sixth Edition, being the last that contains Malone's eorrections and notes issued during his lifetime.

"BOSWELL's LIFE of JoHNSON" is a work that has become so overburdened with notes, commentaries and speculations, that the Editor has thought it advisable in this edition to include at the foot of the text only the notes by Boswell himself. Such other notes, with those of his own, as have been deemed necessary by the present editor will be found at the end of the volume; as well as short biographies of those whose names occur in the work, arranged in the form of a biographical dictionary, and a somewhat longer one of Boswell himself.

These, in conjunction with Boswell's Notes, will, it is hoped, afford all the information that is necessary, without detracting from the appearance of the volume, or distracting the reader's attention while perusing it.

The Editor's notes will be found to be in no way controversial, or in contradiction of Boswell, but simply in explanation of what is obscure.

Some modern editors-notably Mr Croker-have taken it upon themselves to divide the work into chapters; the present editor has thought it wiser to leave the work as it originally was. The editor has thought well to include also "The Tour to the Hebrides," as being a companion work almost inseparable from the "Life."

Illustrations-Portrait of Samuel Johnson (Photogravure); Portrait of James Boswell;

"The Round Robin "; Facsimiles of Johnson's Writing; Boswell's Map of the Tour.

Size-Large super royal $8 v 0,10 \frac{1}{4}$ by $7 \frac{1}{4}$ inches.

Type-Re-set from New Bourgeois Type, and printed with large margins. 

ster Family Library of Velerinany Medicine Howings School of V/eterinary Medicine at

Tuís University

200 Westboro Road

Nowth Grenton RAA 01536 



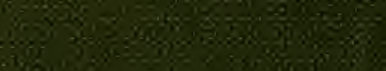

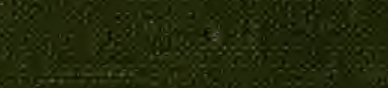

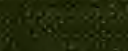

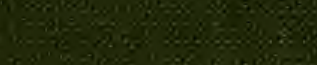 \\ sideng}

$$
35
$$

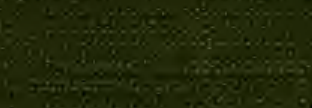

\section{re}

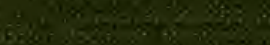

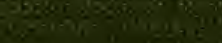

2

(⿻)

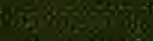

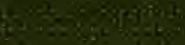

$$
\text { ats }
$$

Hest

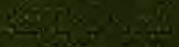

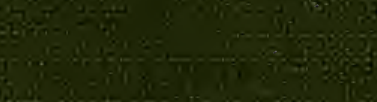

a

$2.53,0$

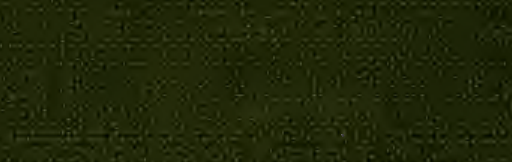

S.

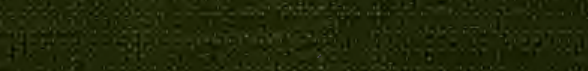

6.

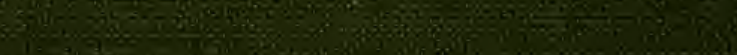

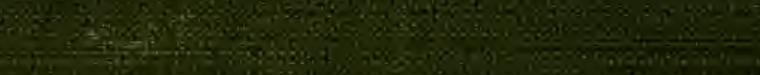

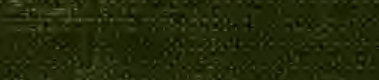

1.

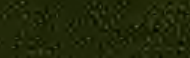

20. 